\title{
Synthesis of late Paleozoic and Mesozoic eolian deposits of the Western Interior of the United States
}

\author{
RONALD C. BLAKEY ${ }^{1}$, FRED PETERSON ${ }^{2}$ and GARY KOCUREK ${ }^{3}$ \\ ${ }^{I}$ Department of Geology, Northern Arizona University, Flagstaff, AZ 86011 (U.S.A.) \\ ${ }^{2}$ U.S. Geological Survey, Denver, CO 80225 (U.S.A.) \\ ${ }^{3}$ Department of Geological Sciences, University of Texas, Austin, TX 78713 (U.S.A.)
}

(Received November 1, 1986; revised and accepted February 11, 1987)

\begin{abstract}
Blakey, R.C., Peterson, F. and Kocurek, G., 1988. Synthesis of late Paleozoic and Mesozoic eolian deposits of the Western Interior of the United States. In: G. Kocurek (Editor), Late Paleozoic and Mesozoic Eolian Deposits of the Western Interior of the United States. Sediment. Geol., 56: 3-125.
\end{abstract}

Late Paleozoic and Mesozoic eolian deposits include rock units that were deposited in ergs (eolian sand seas), erg margins and dune fields. They form an important part of Middle Pennsylvanian through Upper Jurassic sedimentary rocks across the Western Interior of the United States. These sedimentary rock units comprise approximately three dozen major eolian-bearing sequences and several smaller ones. Isopach and facies maps and accompanying cross sections indicate that most eolian units display varied geometry and complex facies relations to adjacent non-eolian rocks.

Paleozoic erg deposits are widespread from Montana to Arizona and include Pennsylvanian formations (Weber, Tensleep, Casper and Quadrant Sandstones) chiefly in the Northern and Central Rocky Mountains with some deposits (Hermosa and Supai Groups) on the Colorado Plateau. Lower Permian (Wolfcampian) erg deposits (Weber, Tensleep, Casper, Minnelusa, Ingleside, Cedar Mesa, Elephant Canyon, Queantoweap and Esplanade Formations) are more widespread and thicken into the central Colorado Plateau. Middle Permian (Leonardian I) erg deposits (De Chelly and Schnebly Hill Formations) are distributed across the southern Colorado Plateau on the north edge of the Holbrook basin. Leonardian II erg deposits (Coconino and Glorieta Sandstones) are slightly more widespread on the southern Colorado Plateau. Leonardian III erg deposits formed adjacent to the Toroweap-Kaibab sea in Utah and Arizona (Coconino and White Rim Sandstones) and in north-central Colorado (Lyons Sandstone).

Recognized Triassic eolian deposits include major erg deposits in the Jelm Formation of central Colorado-Wyoming and smaller eolian deposits in the Rock Point Member of the Wingate Sandstone and upper Dolores Formation, both of the Four Corners region. None of these have as yet received a modern or thorough study.

Jurassic deposits of eolian origin extend from the Black Hills to the southern Cordilleran arc terrain. Lower Jurassic intervals include the Jurassic part of the Wingate Sandstone and the Navajo-Aztec-Nugget complex and coeval deposits in the arc terrain to the south and west of the Colorado Plateau. Major Middle Jurassic deposits include the Page Sandstone on the Colorado Plateau and the widespread Entrada Sandstone, Sundance Formation, and coeval deposits. Less extensive eolian deposits occur in the Carmel Formation, Temple Cap Sandstone, Romana Sandstone and Moab Tongue of the Entrada Sandstone, mostly on the central and western Colorado Plateau. Upper Jurassic eolian deposits include the Bluff Sandstone Member and Recapture Member of the Morrison Formation and Junction Creek Sandstone, all of the Four Corners region, and smaller eolian deposits in the Morrison Formation of central Wyoming and apparently coeval Unkpapa Sandstone of the Black Hills.

Late Paleozoic and Mesozoic eolian deposits responded to changing climatic, tectonic and eustatic controls that are documented elsewhere in this volume. All of the eolian deposits are intricately interbedded with non-eolian deposits, including units of fluvial, lacustrine and shallow-marine origin, clearly dispelling the myth that eolian sandstones are simple sheet-like bodies. Rather, these units form some of the most complex bodies in the stratigraphic record. 


\section{Introduction}

The most voluminous expanse of eolian depositional systems in the geological record occurs across the Western Interior of the United States. The area stretches from southern Nevada and adjacent California across the Mogollon Rim of Arizona across the northern half of New Mexico into the Texas and Oklahoma panhandles, northward through eastern Utah and western Colorado, eastward into north-central Colorado, northward into Wyoming and the Black Hills of South Dakota, west into southwestern Montana, and full circle south along the Cordilleran Hinge Line through southwest Utah to southern Nevada (Fig. $1^{*}$ ). Within this vast area, the greatest concentration of eolian-bearing formations occurs on the Colorado Plateau in south-central Utah and adjacent Arizona (Blakey, this volume). Eolian deposition began in the Early and Middle Pennsylvanian (Atokan, Desmoinesian), reached an initial climax during the early Permian (Wolfcampian, Leonardian), waned during the Triassic, and reached a second climax during the Middle Jurassic; eolian deposition declined during the Late Jurassic and is absent in the Cretaceous (Fig. 2). Thus eolian deposits are distributed throughout $160 \mathrm{~m} . \mathrm{y}$. of time and dominated deposition in some areas.

\section{Purpose and scope}

The chief purpose of this paper is to describe the geometry of the late Paleozoic and Mesozoic eolian deposits of the Western Interior. We are presenting an atlas that documents geometry, stratigraphy, and facies relations of the eolianbearing intervals. The information is presented in a series of maps and cross sections, each of which is carefully documented by maps and tables to the source of the original data.

\section{Methods}

Field-based observations and studies of the authors, both published and unpublished, form

\footnotetext{
* Due to their large size Figs, 1, 4, 5, 6, 8, 9, 10, 11, 12, 13, 15, $17,18,20,21,22,24,25,27,28,30,31,33$ and 34 are placed together on the foldouts in this article.
}

the foundation of this paper; however, most of the basic data has been collected from the literature. The isopachs were constructed from data points that were carefully plotted by township and range, numbered, listed with author, their section designation, interval of study, and thickness of eolian interval. Because much of the information in the literature does not specify the environment of deposition of the rocks of interest or misinterpreted the origin of the rocks, or contains outdated stratigraphic terminology, we used our collective experience to define the eolian intervals within the original authors' section. Thus it is possible for subsequent workers to take our data back to the original source and see how our interpretations fit within the framework of the original authors' work. Space limitations and tremendous breadth of subject demanded that our conclusions be arrived at directly without much discussion or debate of numerous hypotheses.

It should be noted that the isopachs show the thickness of the eolian-bearing interval and not necessarily the thickness of a formal rock-stratigraphic interval or rocks of a particular age (Table 1). In general the isopachs show the thickness of erg or dune deposits from the base of the oldest eolian sandstone to the top of the youngest one. In some instances the thickness of simple, thick, non-eolian tongues is subtracted from the isopached interval. Because many geologic units contain mixtures of eolian and non-eolian rocks, the isopachs may vary considerably from previously published maps of a given formation; or where specified, they may include parts of more than one formation or stratigraphic unit. Most of the maps have patterns that show approximate percentages of eolian rocks within the overall eolian-bearing sequence. If a given eolian interval shows an isopach of $100 \mathrm{~m}$ and a percentage of 50 , this means that the thickness of the eolian-bearing rocks of a given interval is $100 \mathrm{~m}$ and that approximately half of that interval contains eolian-deposited rocks.

We caution the reader that because the maps vary slightly in method of construction, Table 1 must be consulted when examining our presentation of a given eolian sequence; be aware of what the data mean! We found it necessary to vary the 
method of presentation because of the nature of the data. Some of the eolian units are very poorly studied and required some estimation on our part. Some of the differences reflect the great variety in the eolian-bearing deposits themselves. Some of the intervals have not had much previous discussion in the literature but have been the subject of recent study and therefore are covered in more depth here than some of the better-known eolian deposits. In general, our interpretation of amounts and distribution of eolian-formed rocks is probably conservative; that is, we expect that future detailed studies will likely show an increase in the volume of eolian deposits in the interval of study.

Cross-sections of the eolian sequences were constructed to show the lateral relations of the rocks of interest. These sections indicate the distribution of the eolian rocks within the isopached intervals and show which portion of the interval contains the most eolian deposits.

The terminology of this paper (Fig. 2) generally follows accepted previous terminology of earlier workers. No new nomenclature is proposed nor do we attempt to settle old nomenclature disputes except where major revision or updating of stratigraphic terminology was necessary. Both the Permian and Jurassic rock units are fraught with correlation problems; we readily admit to using our own experience and prejudice where necessary. Because we have concentrated on the eolian rocks, we have been able to trace patterns that have been overlooked by previous geologists. In addition, some major regional correlations of late Paleozoic and Mesozoic rocks have recently appeared in the literature (Condon and Peterson, 1986; Blakey, 1987; Blakey and Knepp, in press). The correlations and definitions of eolian intervals, as used in this report, rely heavily on local and regional stratigraphic data. The recognition and correlation of major regional Jurassic unconformities by Pipiringos and O'Sullivan (1978) strongly aided our correlation and differentiation of the Middle Jurassic eolian deposits. The relations of erg-bearing units to fossiliferous sequences has facilitated the division of Permian rocks (Blakey, 1980). The persistence of certain units such as the redbed Hermit-Organ Rock-Abo Formations of the Permian on the Colorado
Plateau, the red marker presumed to mark the Pennsylvanian-Permian boundary across much of eastern Wyoming, and Jurassic redbed units like the Carmel and Wanakah Formations across the Colorado Plateau greatly aid regional correlation and differentiation of eolian deposits. In some cases the only resolution is by carefully measured and closely spaced measured sections such as those published by O'Sullivan (1980a,b). Well logs proved useful for subsurface correlation where sufficient stratigraphic data was available.

An apparent discrepancy exists in the number of maps shown per interval of geologic time. Although the Pennsylvanian Period spans approximately $30 \mathrm{~m} . \mathrm{y}$. and the Middle Jurassic only 16 m.y., we show only one facies-isopach map for the former and six for the latter. Pennsylvanian ergs are widespread and are locally datable to smaller subdivisions of the period. However, these subdivisions cannot be recognized on a regional basis. The Middle Jurassic, however, has been subdivided and rocks correlated regionally by use of unconformities as shown by Pipiringos and O'Sullivan (1978). Four of the Jurassic intervals we show are relatively small, easily distinguishable, and therefore separable as shown on the maps. To attempt the same with Pennsylvanian eolian deposits would not be practical at present.

The general regional stratigraphy of the late Paleozoic and Mesozoic of the Western Interior and the location of the eolian deposits is shown on Fig. 2. The cross-sections presented later in this paper detail the relations between the erg and non-erg deposits. By carefully comparing our maps and cross-sections and referring back to the original references cited in the tables, the reader should be able to clearly see how our conclusions were reached; therefore, our presentations of geometries of eolian-formed units should still prove useful even if subsequent work shows adjustment to be necessary in regional correlation. The authors are responsible for the construction of the isopachs as follows: Blakey-Paleozoic, Jelm, Wingate units; Kocurek-Page and Entrada Sandstones; Peterson-Temple Cap, Romana and Morrison-age units; Peterson (with assistance from Larry Middleton) - Navajo Sandstone and related units. 


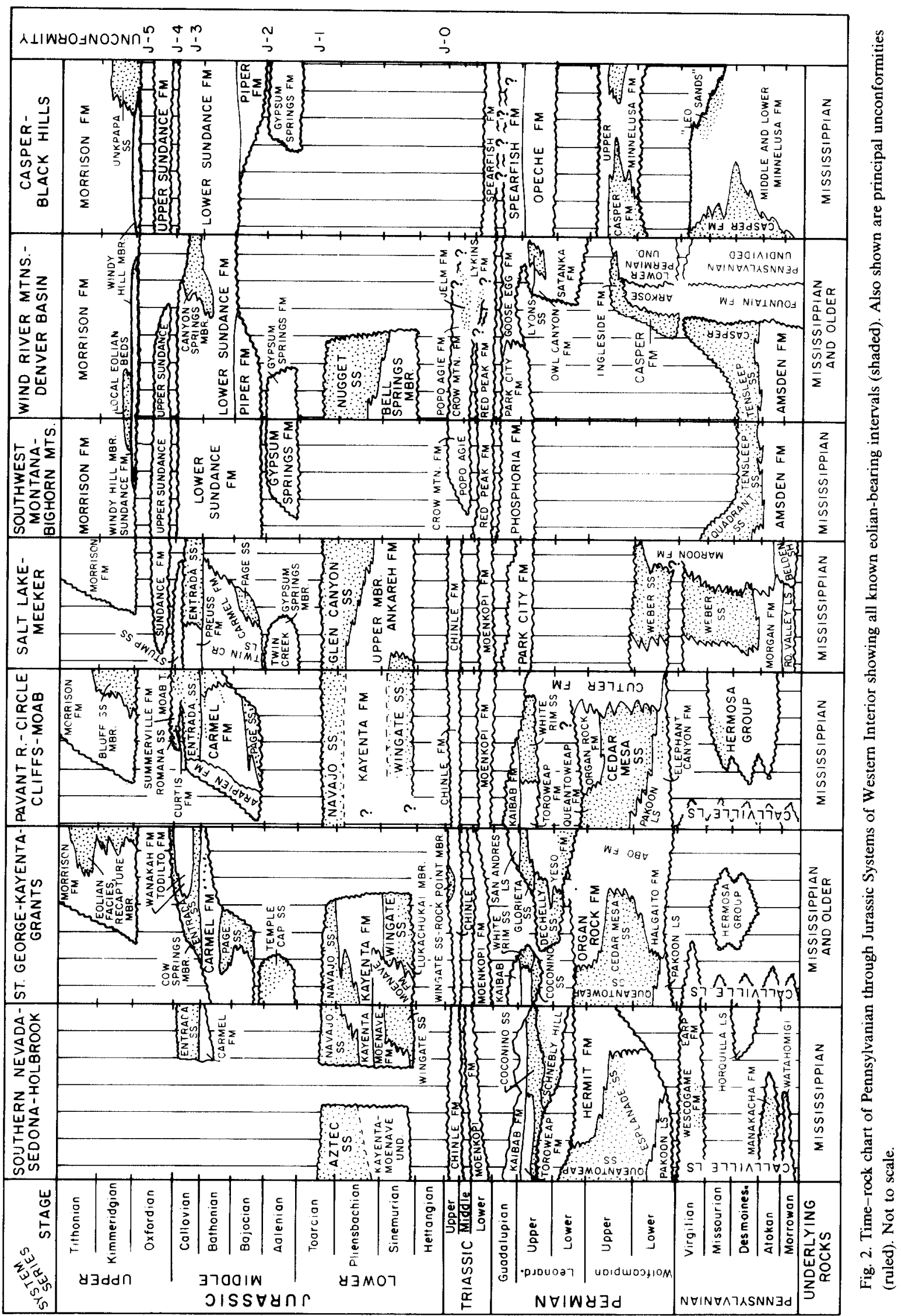


The presentation of each eolian-bearing sequence will follow the same format. Description in the text will be brief, especially in cases where the rocks are well described in previous literature. Emphasis will be placed on facies and geometric relations of the eolian units, especially lateral configurations. We will show that few eolian deposits are simple layer-cake sand bodies, and rather that most are complex units that change vertically and laterally and show strong diachronous characteristics. Preliminary and general interpretations of erg geometry will be offered, although this topic is more completely discussed in other papers in this volume.

Isopachs alone are insufficient for interpretation of complex sandstone-body geometry. Most of the isopach maps have additional symbols for interpretation of eolian sandstone-body geometry. The lines that show percentage of eolian deposits document trends of increasing or decreasing eolian sediment within an interval. The bounding lines of the eolian interval also aid interpretation of the maps. Zero lines indicate wedge-out of an eolian body, either by pinch-out of the entire interval as in the case of the De Chelly-Schnebly Hill Formation and eastern edge of the Page Sandstone, or pinch-out of eolian sandstone into other facies of the interval as in the case of the western edge of the Page Sandstone. The latter may be accompanied by facies change as well as pinch-out. The narrow saw-toothed lines indicate major facies change throughout the entire erg-bearing interval. Cross-sections aid in the interpretation of eolian geometry. One or more are presented for each interval discussed in the text.

Another situation that is not clearly shown on the maps is the pinch-out of a major eolian tongue with the continuation in the direction of pinch-out of the main eolian body. This can be shown clearly only in cross-section. An example is the Navajo-Kayenta intertonguing across southwestern Utah and north-central Arizona; the main body of the Navajo continues well southwest of the area of major intertonguing. Figure 3 diagrammatically shows various types of eolian sandstone margins and refers to a real example of each.

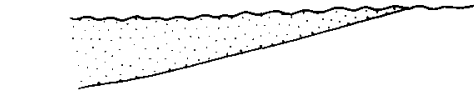

1. Pinch-out by truncation beneath unconformity (e.g. eost edge Navajo SS)

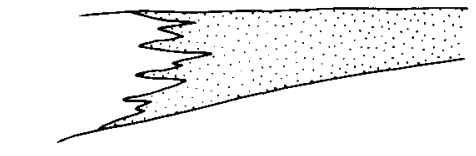

2. Vertically stacked facies change (e.g. west edge Cedar Meso SS)
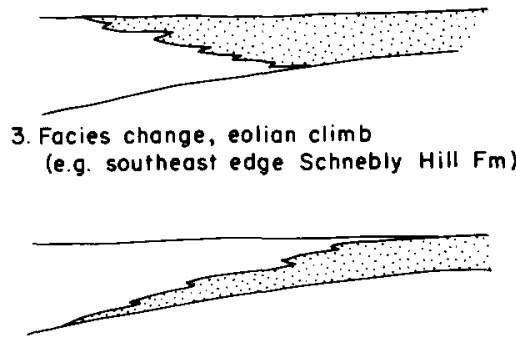

4. Facies change, non-eolian climb (e.g. south edge Wingate SS)

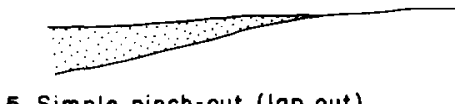

5. Simple pinch-out (lap out)

(e.g. eost edge Page SS)

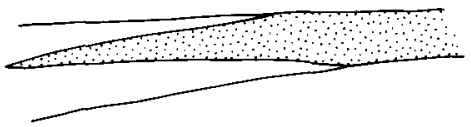

6. Simple pinch-out of single tongue (e.g. east edge White Rim SS I
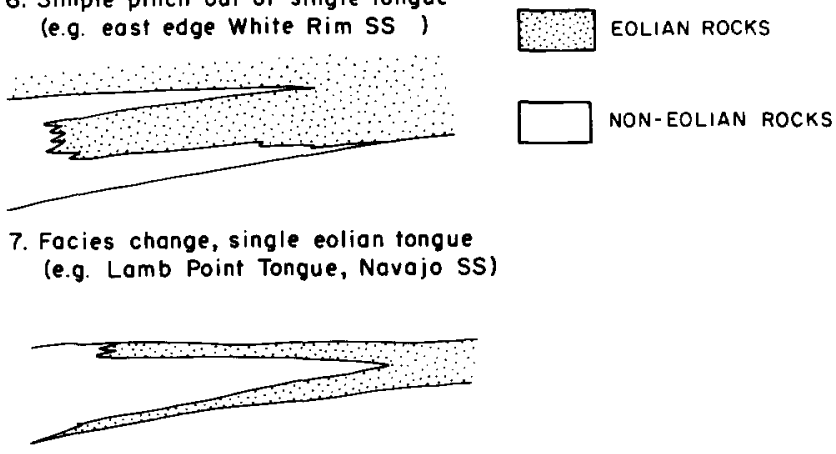

8. Split by non-eolian tongue (e.g. west edge Page SS)

Fig. 3. Simple cross-sections depicting geometry of various margins of ergs. An example from eolian sandstones of the Western Interior is given for each. Compare with actual isopach maps and cross sections for true scale and geometry. 
Many eolian sandstones have one or more margins that were removed by later erosion or are covered by younger strata and no subsurface data is available. This is most common along the western and southern margins of the region of study.

\section{Late Paleozoic eolian deposits}

\section{Introduction}

The late Paleozoic eolian sandstones range in age from Atokan to late Leonardian and possibly Guadalupian (Fig. 2). They are divided here into five erg-bearing sequences: Pennsylvanian, Wolfcampian, Leonardian I, Leonardian II and Leonardian III. Each sequence is intercalated with or bracketed by fossil-bearing rocks. Pennsylvanian eolian deposits are primarily distributed north of the Ancestral Rockies, whereas Permian ergs are extensively distributed to the southwest of these major barriers. Figure 4 shows the distribution of late Paleozoic tectonic elements that affected Pennsylvanian and Permian deposition.

\section{Pennsylvanian eolian deposits}

Pennsylvanian eolian deposition is widespread and has been documented from the lower Casper Formation (Steidtmann, 1974), lower Tensleep Sandstone (Mankiewicz and Steidtmann, 1979; Kerr, this volume) and Quadrant Sandstone (Saperstone and Ethridge, 1984) in Wyoming and adjacent Montana and Colorado, in the lower Weber Sandstone of Utah, Wyoming and Colorado (Bissell and Childs, 1958; Driese and Dott, 1984), and from the Honaker Trail Formation of the Hermosa Group of southeastern Utah (Loope, 1984). In addition, eolian sandstone is present in the Manakacha and Wescogame Formations of the Supai Group in northern Arizona but has yet to be documented in the literature. The Pennsylvanian age of each of the above is well documented by intercalated fossil-bearing marine rocks. Figure 5 and Table 2 present the data base for Pennsylvanian and Permian eolian deposits.

The Pennsylvanian deposits, although almost certainly a series of separate ergs ranging from Atokan to Virgilian in age, are herein isopached on a single map. Eolian-bearing units consist of several stratigraphic units across Wyoming, southern Montana, northern Utah and northern Colorado (Fig. 6). The lack of detailed stratigraphic and sedimentologic data prevent further subdivision. The eolian deposits in southeastern Utah and the Grand Canyon region do not have sufficient data available to construct isopachs; only their known and inferred lateral distribution are shown. For simplicity, the northern sand body will be referred to as the Tensleep complex and it also includes part of the Weber, Quadrant and Casper stratigraphic units. The Tensleep forms a broad sheet across the Central and Northern Rocky Mountain region that generally ranges to $100 \mathrm{~m}$ thick but the erg-bearing interval locally exceeds $300 \mathrm{~m}$ in northern Utah and $500 \mathrm{~m}$ in southwestern Montana (Bissell and Childs, 1958; Mallory, 1967; Saperstone and Ethridge, 1984). Figure 7A, $B$ and $C$ shows the Tensleep and related units in cross-section. Although the unit is renowned for exposures of large-scale, high-angle sand-flow strata that dip to the south and southeast (Steidtmann, 1974; Mankiewicz and Steidtmann, 1979), detailed sedimentologic studies have documented a broad variety of eolian stratification styles including small-scale trough and planar-tabular wind-ripple cross strata, horizontal to gently inclined wind-ripple strata, and wet and dry interdune deposits (Mankiewicz and Steidtmann, 1979; Driese and Dott, 1984; Saperstone and Ethridge, 1984; Kerr, this volume; J. Haslett, pers. commun., 1986). In addition, each of the above authors have noted interbedding of eolian and marine-sabkha strata within the Tensleep Sandstone, especially near erg-deposit margins.

The Tensleep complex is a north-northwesttrending sandstone body (Fig. 6) bordered by marine clastic and carbonate rocks to the west (Oquirrh and Wood River Groups and related rocks), marine carbonate to the east (lower Minnelusa Formation and related rocks), and fluvial clastic rocks to the south (Maroon Formation and Fountain Arkose; Maughan and Wilson, 1960). Little is known about the erg margins to the north, although Stewart and Walker (1980) reported Pennsylvanian eolian deposits in the Rockies of southern Canada. 
A

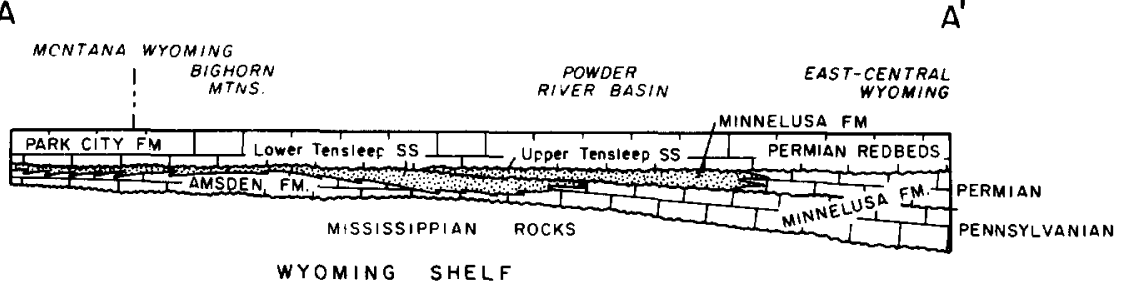

SYMBOLS USED ON ALL CROSS SECTIONS
Eolian Sondstone
Redbeds, Noneolion SS
Garbonate
$\square$ Gypsum
$\because$ Halite
$\because$ Arkose

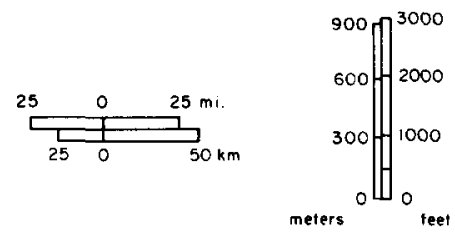

B
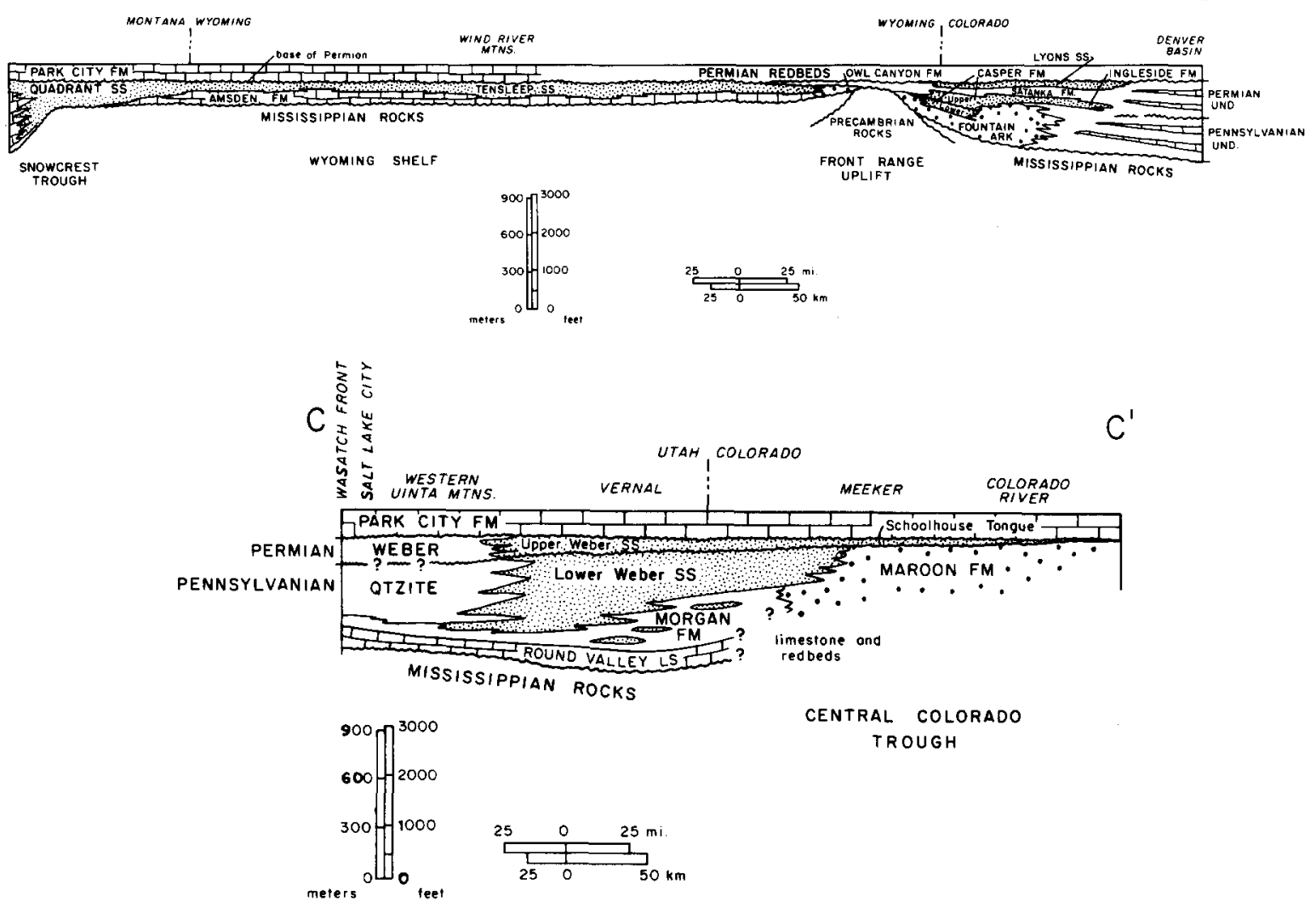

Fig. 7. Restored cross-sections of Pennsylvanian and Permian eolian deposits. Locations shown on Fig. 5.

The Pennsylvanian eolian deposits of the central and southern Colorado Plateau (Fig. 7D and E) are less well known. Loope (1984) described the sedimentology of a 150 m-thick eolian sequence in the Honaker Trail Formation from a relatively small area so regional isopachs cannot be constructed. The eolian deposits are complexly intercalated with marine carbonate. Whether these represent isolated dune deposits or tongues of a larger yet undescribed erg is unknown. 


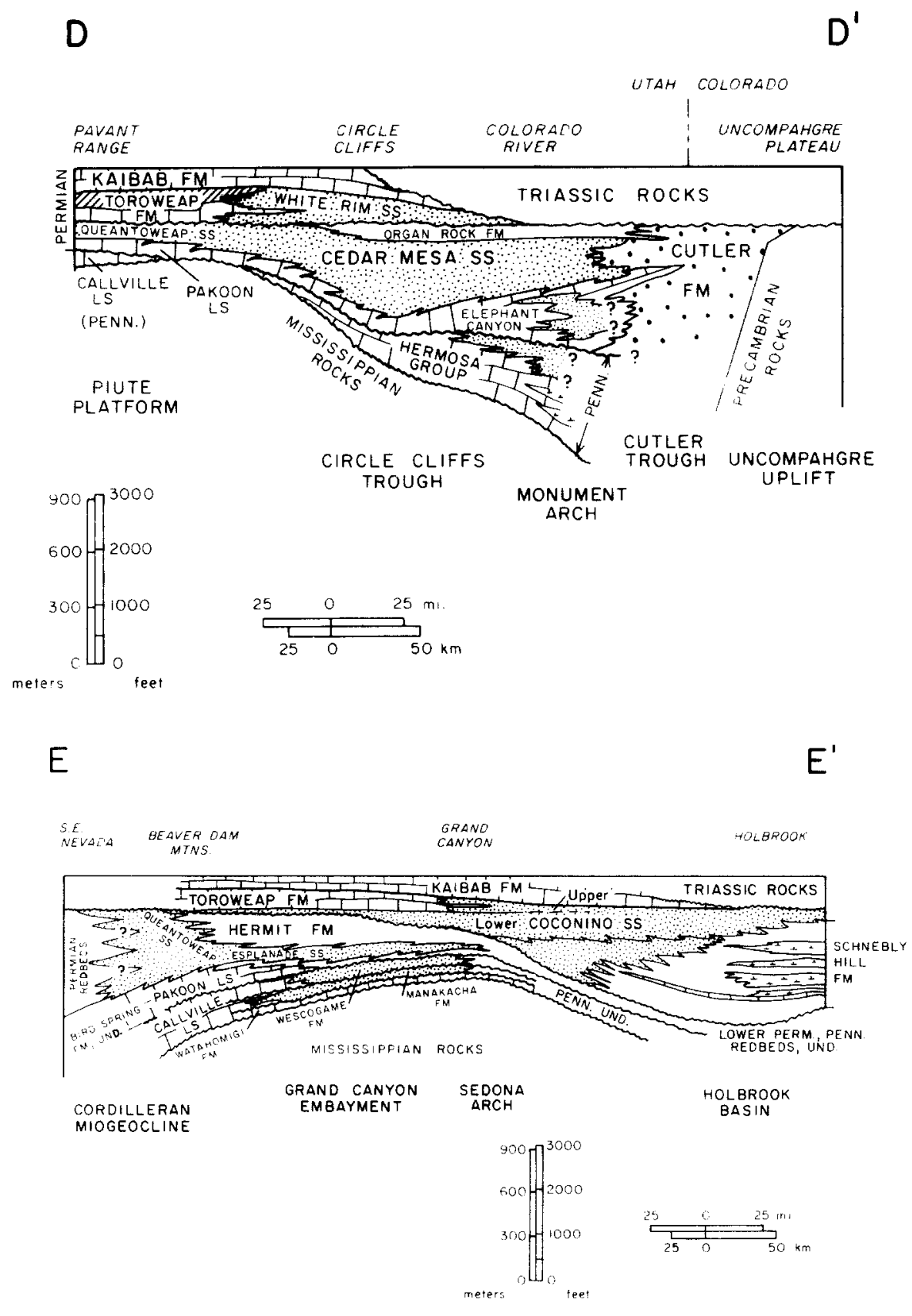

The eolian deposits in the Manakacha and Wescogame Formations of the Supai Group in the Grand Canyon and Mogollon Rim are not described in the literature. Blakey (unpublished data) has studied eolian deposits in the Mogollon Rim and observed eolian strata in the Grand Canyon as has Peterson (unpublished data). One coset of probable eolian strata in the Manakacha Forma- tion was estimated to be $20 \mathrm{~m}$ thick. R. Hunter (pers. commun., 1985) reported to Blakey the presence of eolian strata in the Supai Group of Grand Canyon. The two formations each range from 30 to $70 \mathrm{~m}$ thick where eolian strata are suspected and may be about half eolian in origin. Interestingly, McKee (1982) made no mention of eolian deposits in the Supai Group, yet some of 


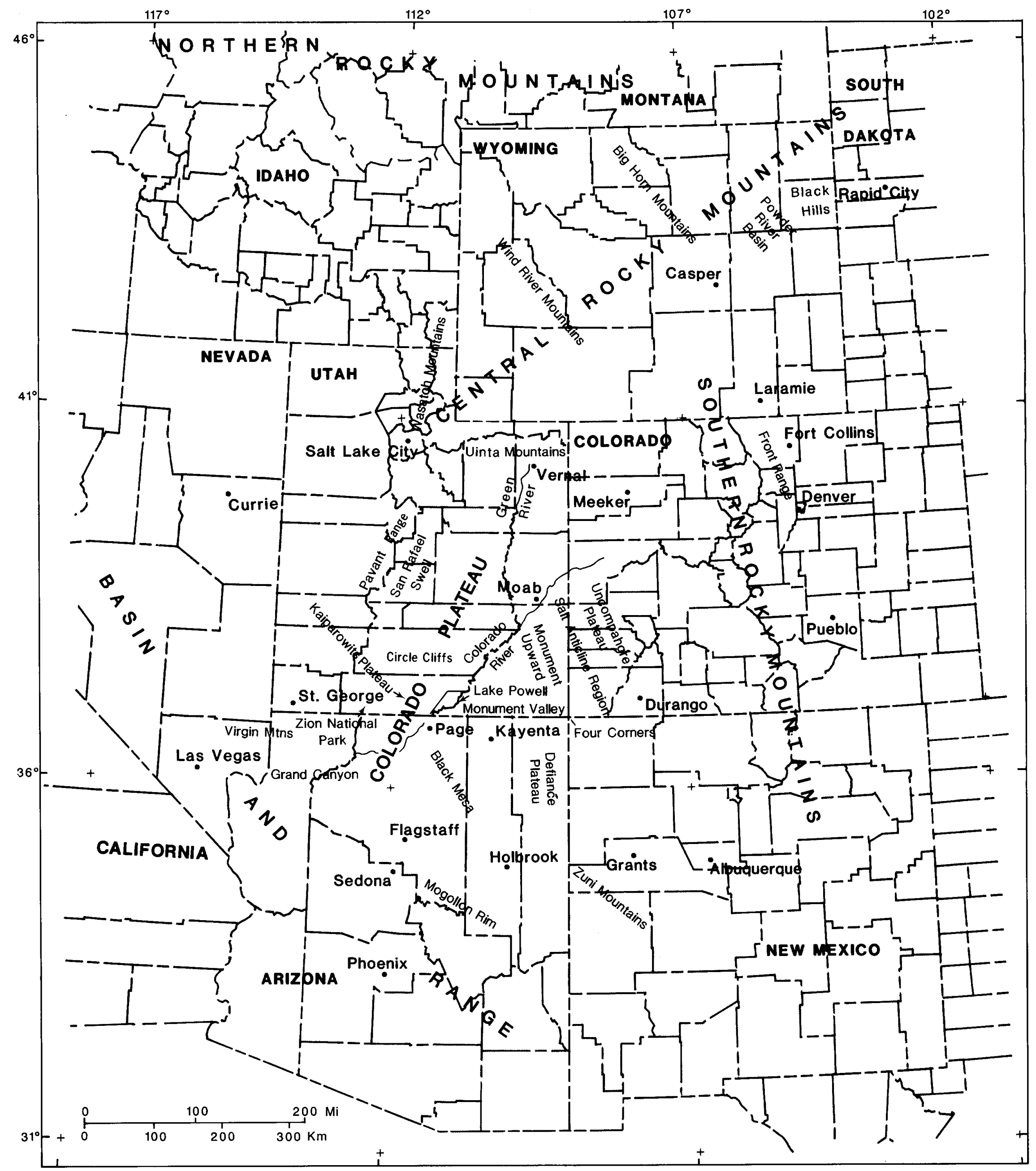

Fig. 1. Index map of Western Interior of United States showing geographic locations mentioned in text. 


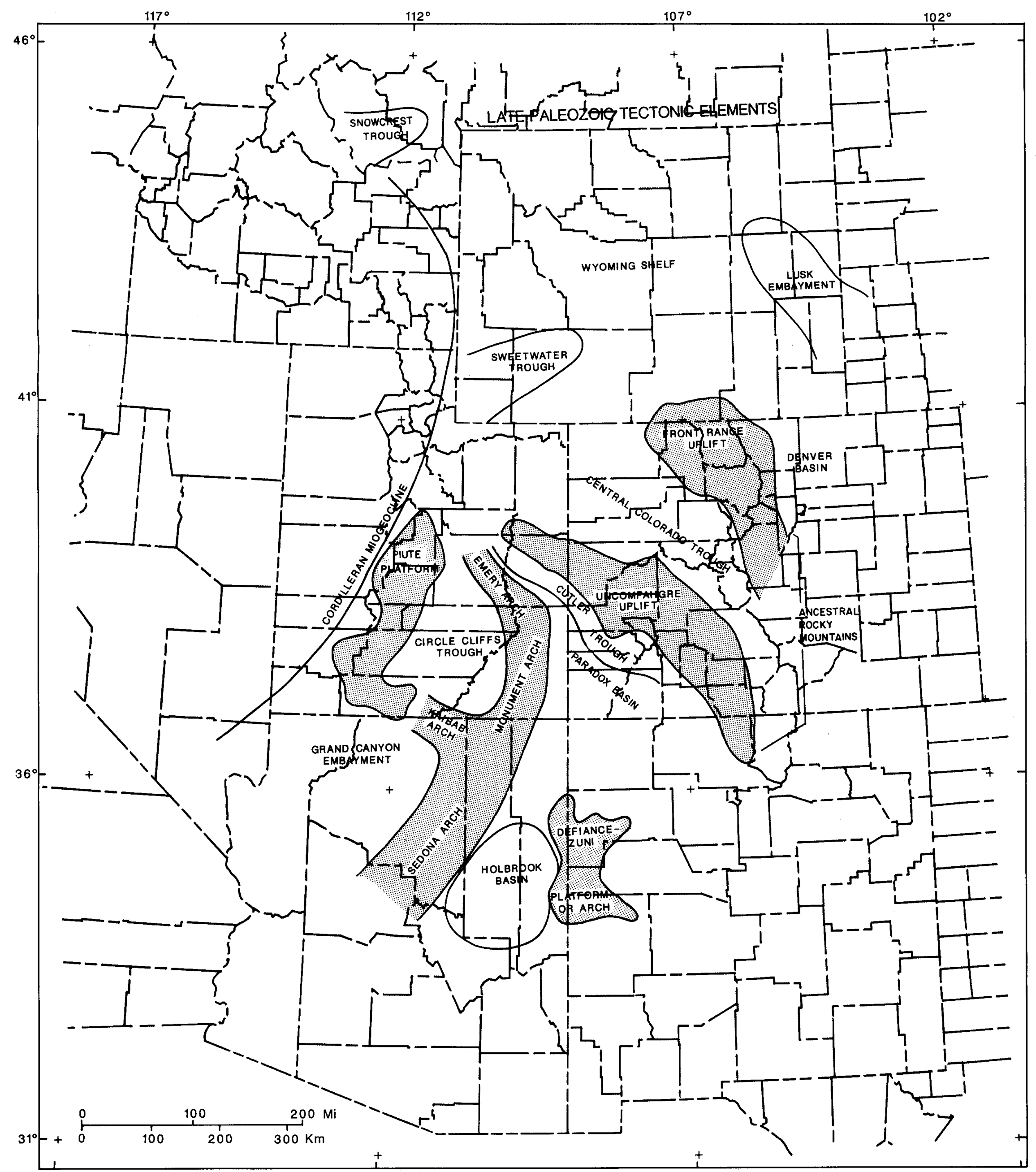

Fig. 4. Generalized late Paleozoic tectonic elements that influenced sedimentation in Pennsylvanian and Permian eolian-bearing rocks of the Western Interior. Boundaries are approximate and varied through time. 


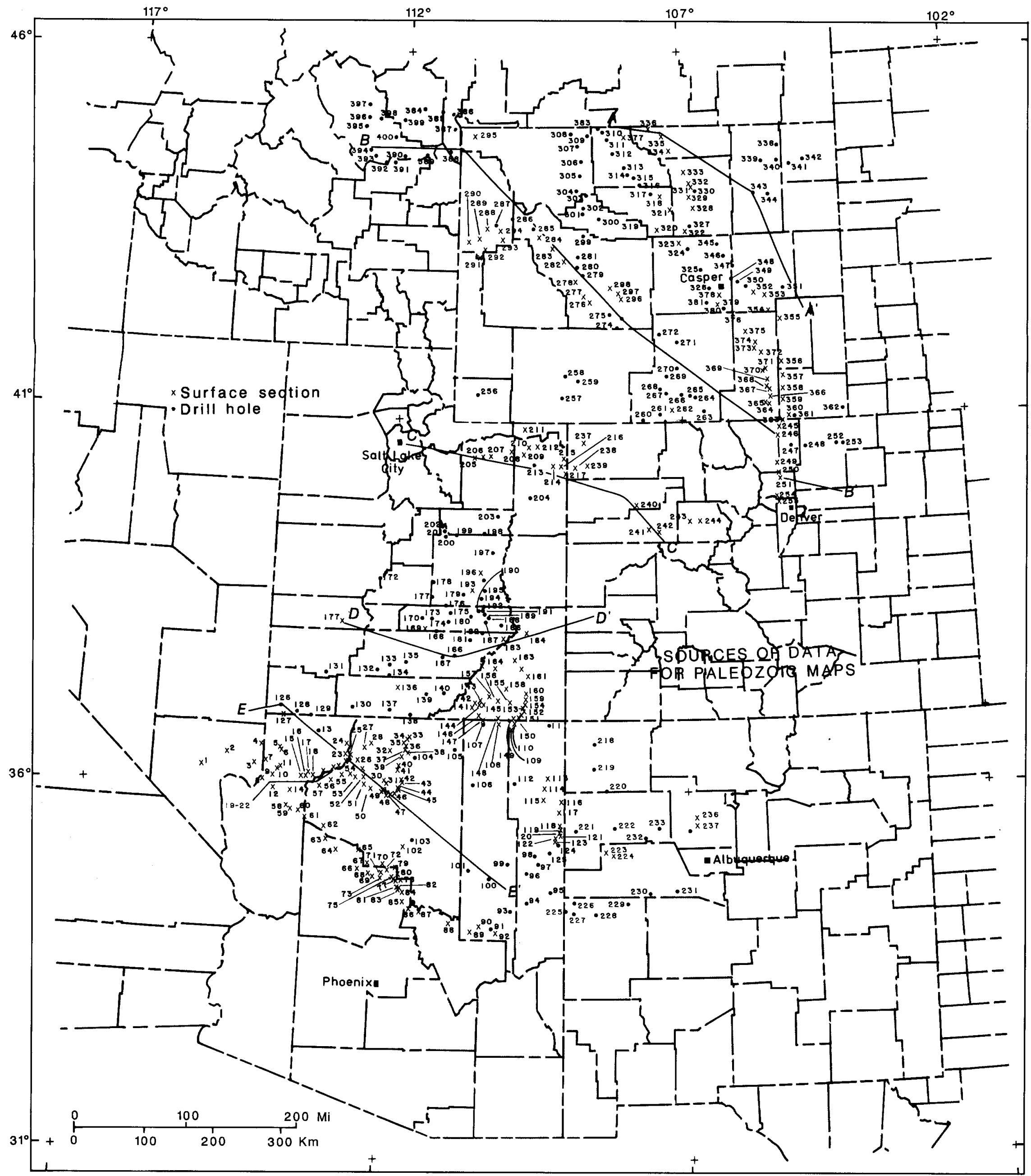

Fig. 5. Data points for late Paleozoic eolian deposits also showing lines of cross section. See Table 2 for location names and references. 




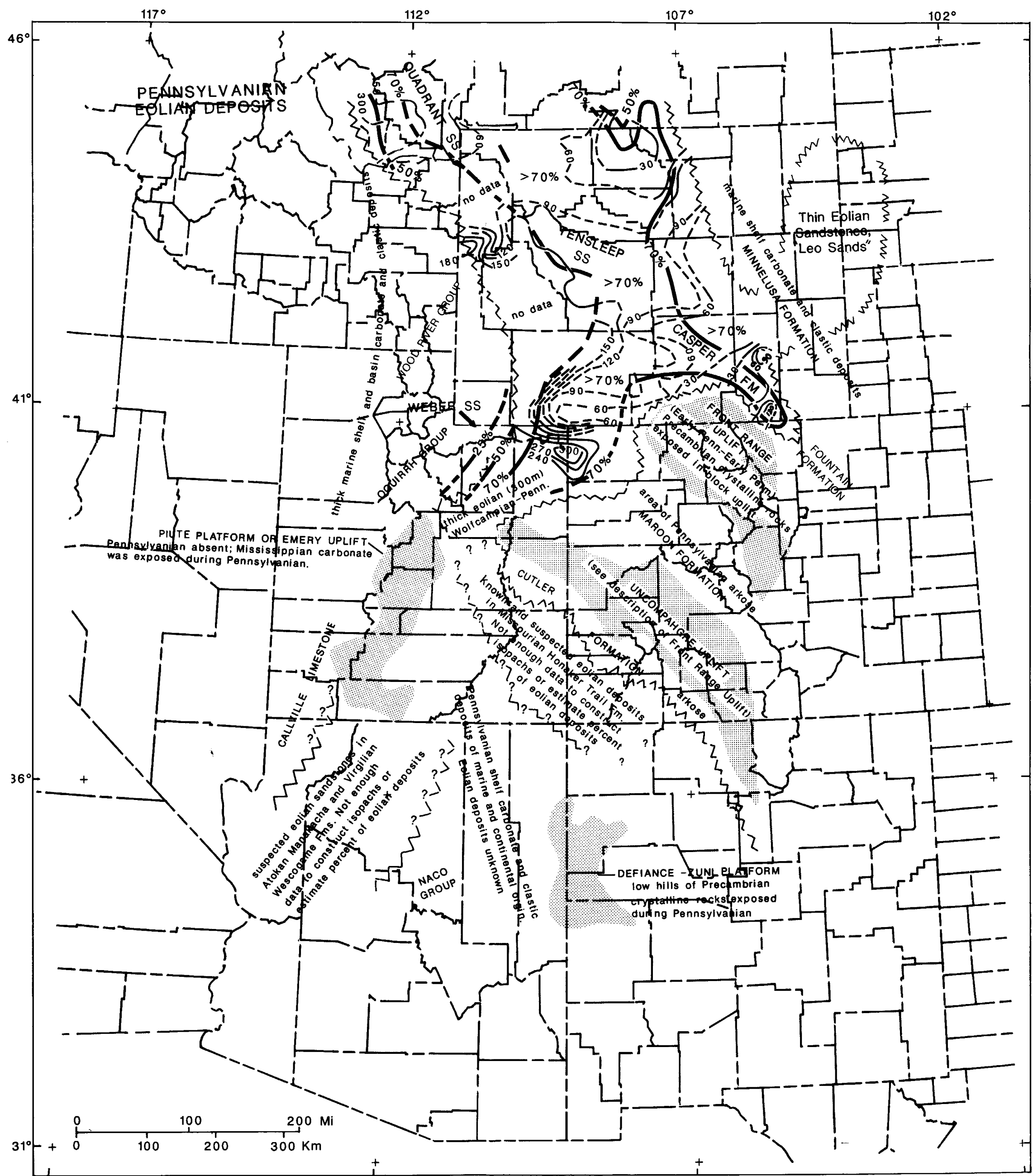




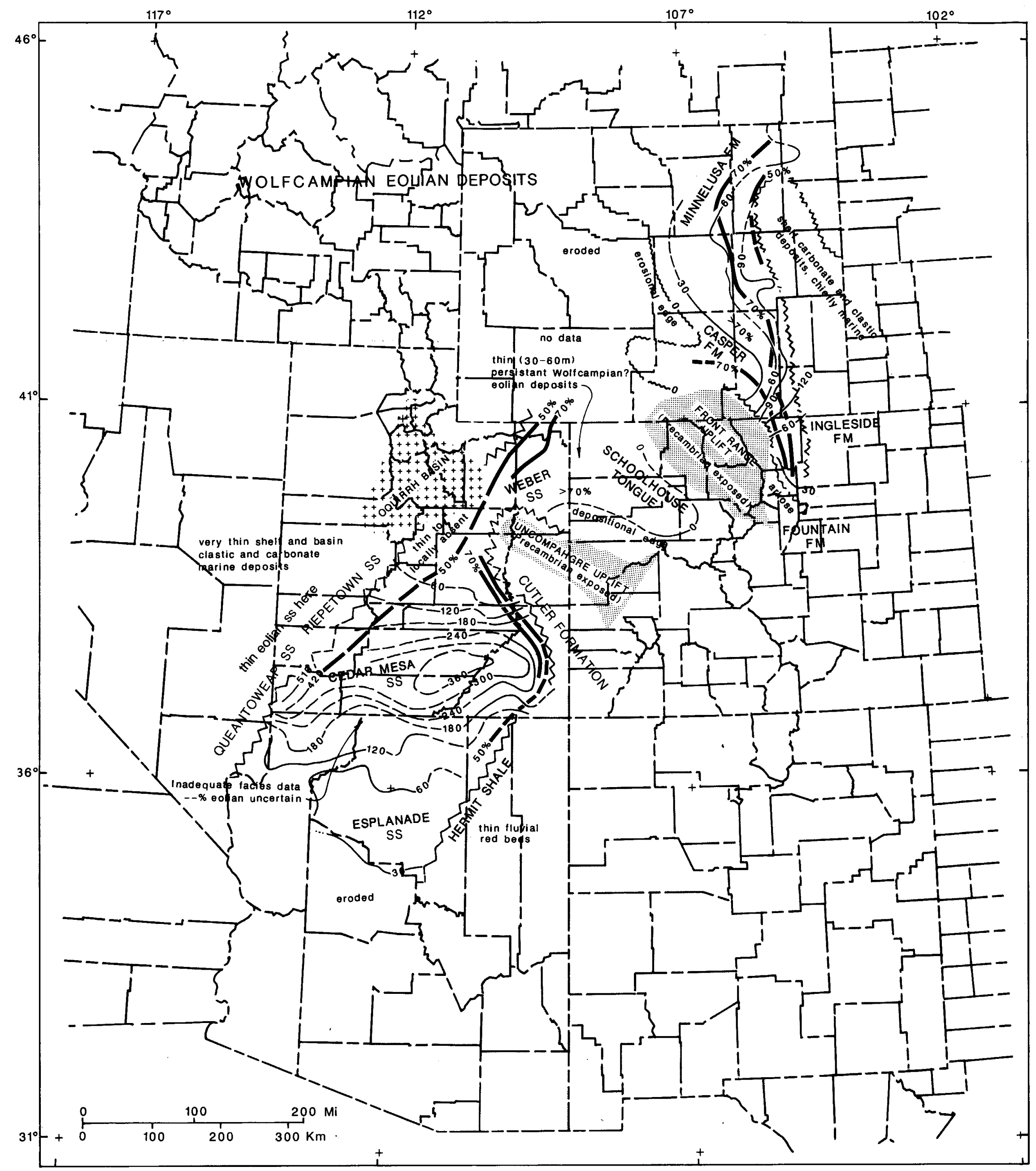





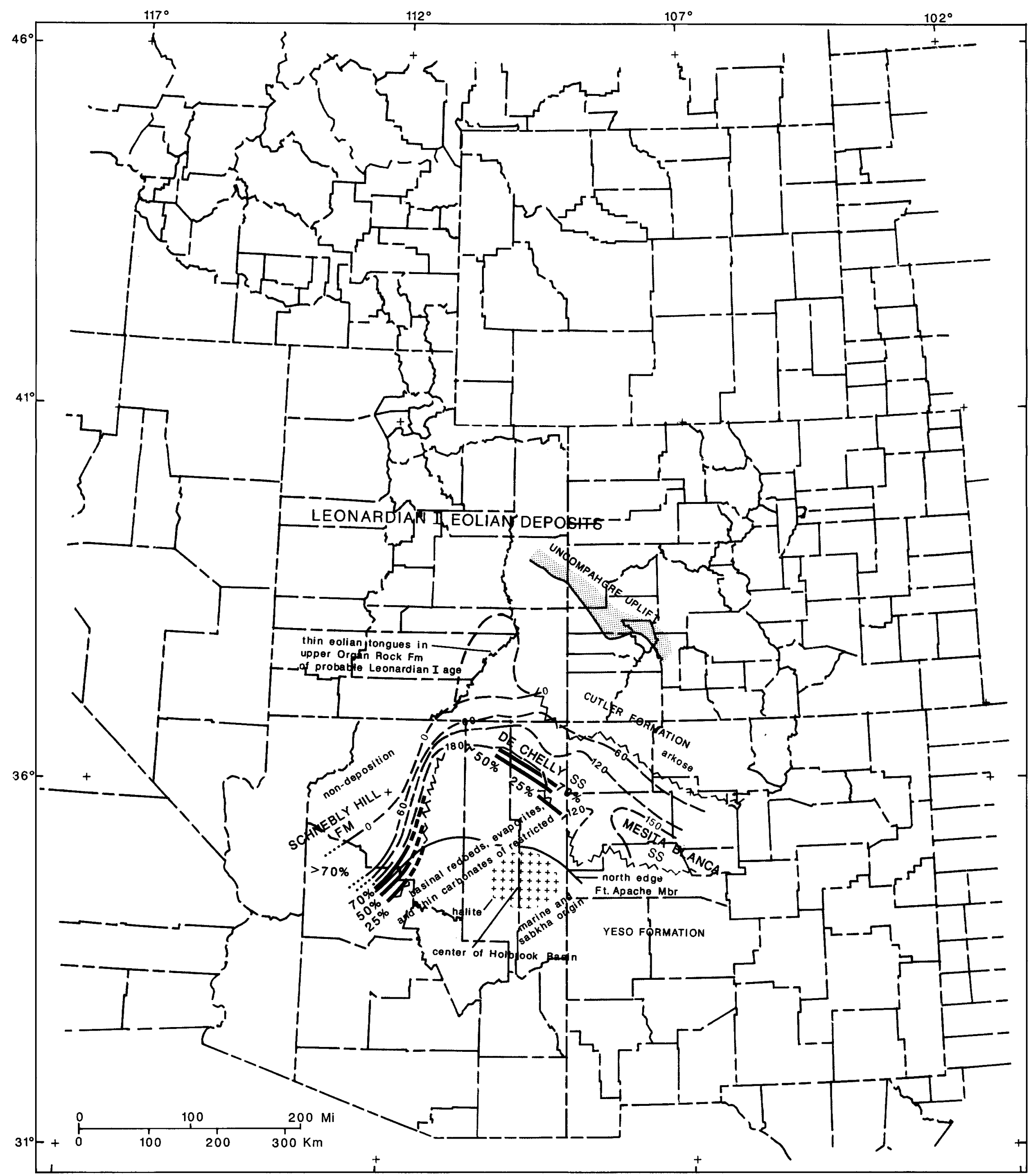

Fig. 9. Geometry and facies relations of Leonardian I eolian deposits. Heavy lines show approximate percentage of eolian sandstone. Isopach interval 30 and $60 \mathrm{~m}$. Solid lines where outcrops occur; dashed lines where interval in subsurface or removed by erosion. 


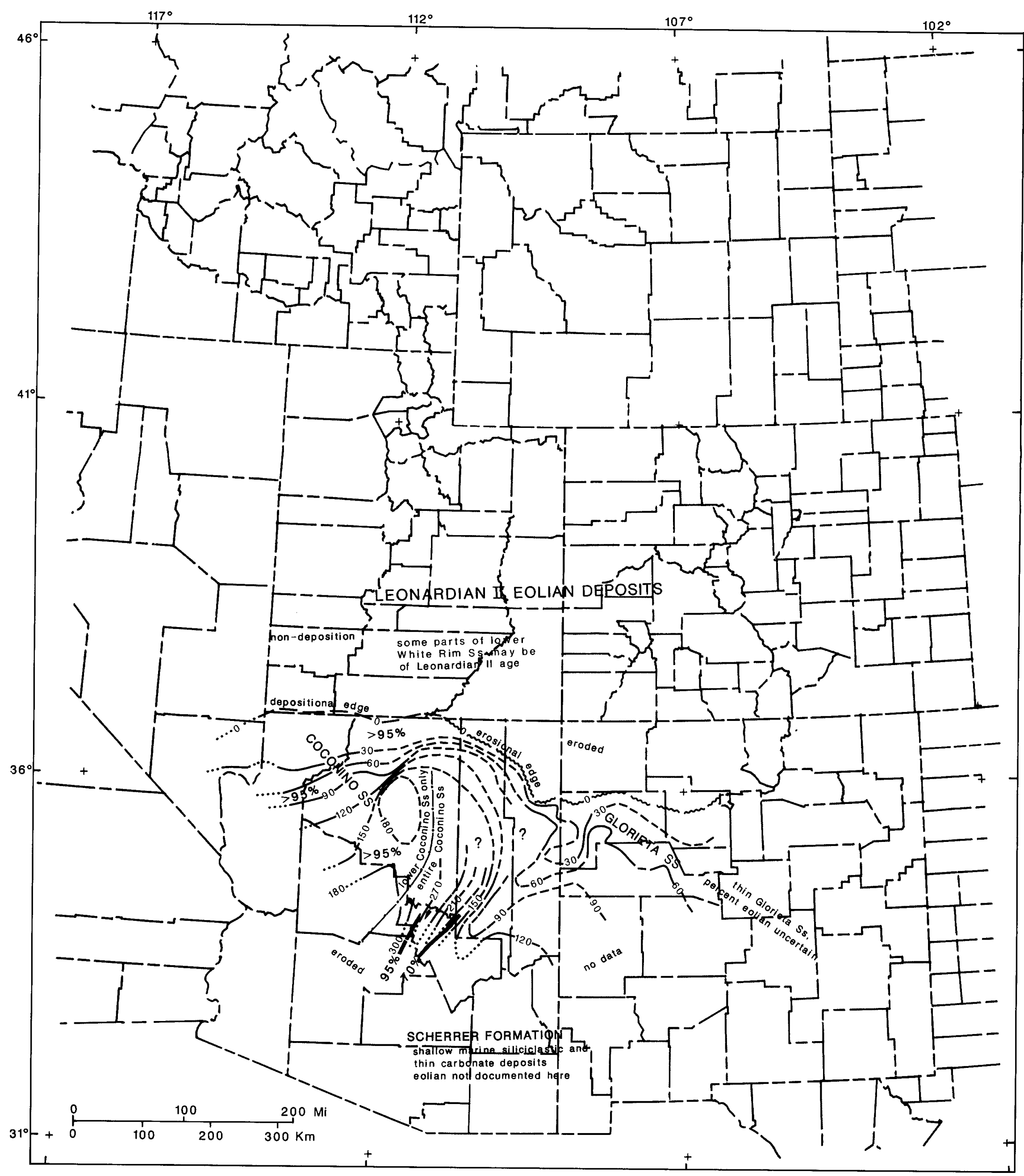

Fig. 10. Geometry and facies relations of Leonardian II eolian deposits. Heavy lines show approximate percentage of eolian sandstone. Isopach interval $30 \mathrm{~m}$. Solid lines where outcrops occur; dashed lines where interval in subsurface or removed by erosion. 


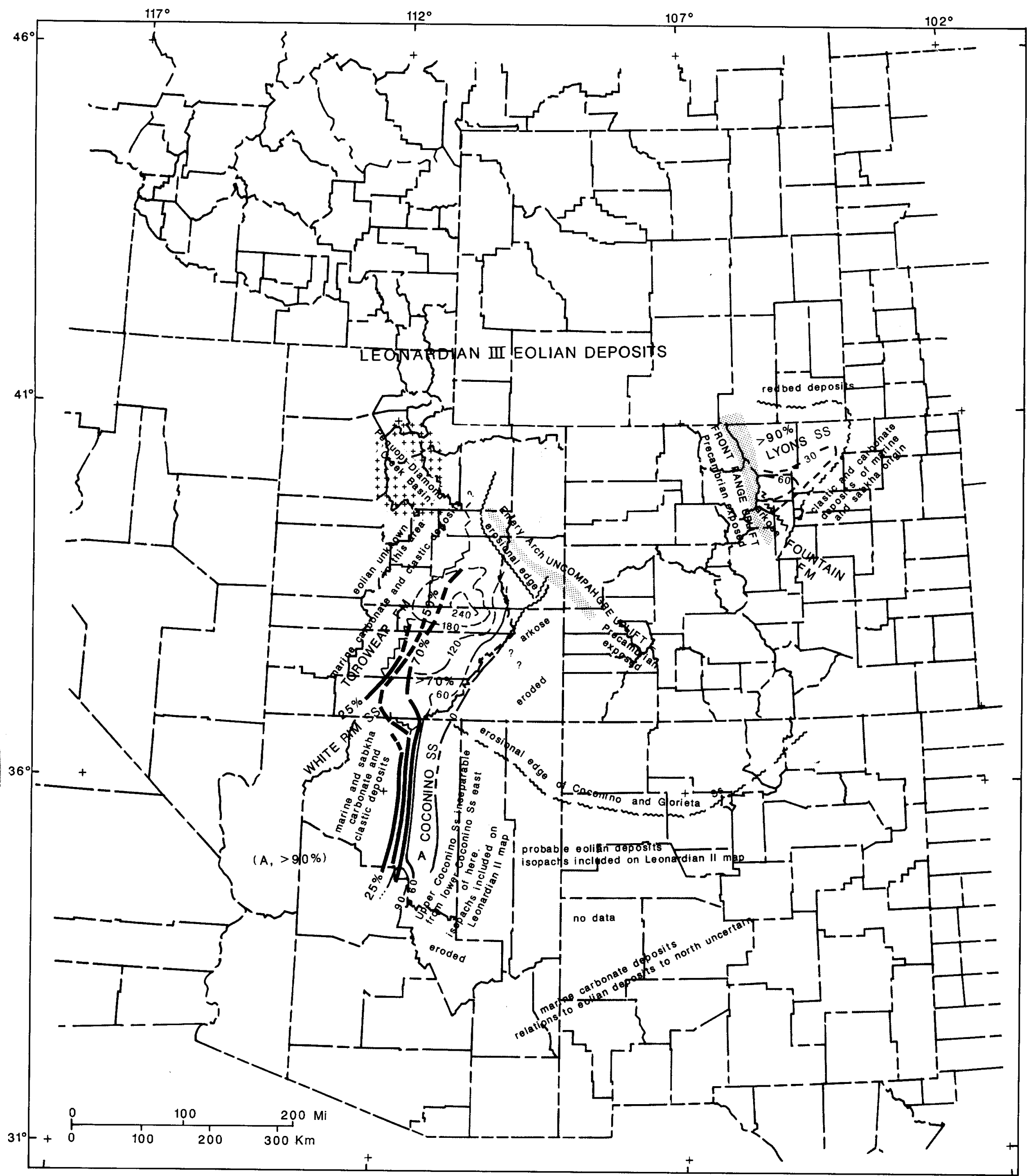

Fig. 11. Geometry and facies relations of Leonardian III eolian deposits. Heavy lines show approximate percentage of eolian sandstone. Correlations from Colorado Plateau to north-central Colorado based on regional relations that are subject to verification. Isopach interval 30 and $60 \mathrm{~m}$. Solid lines where outcrops occur; dashed lines where interval in subsurface or removed by erosion. 



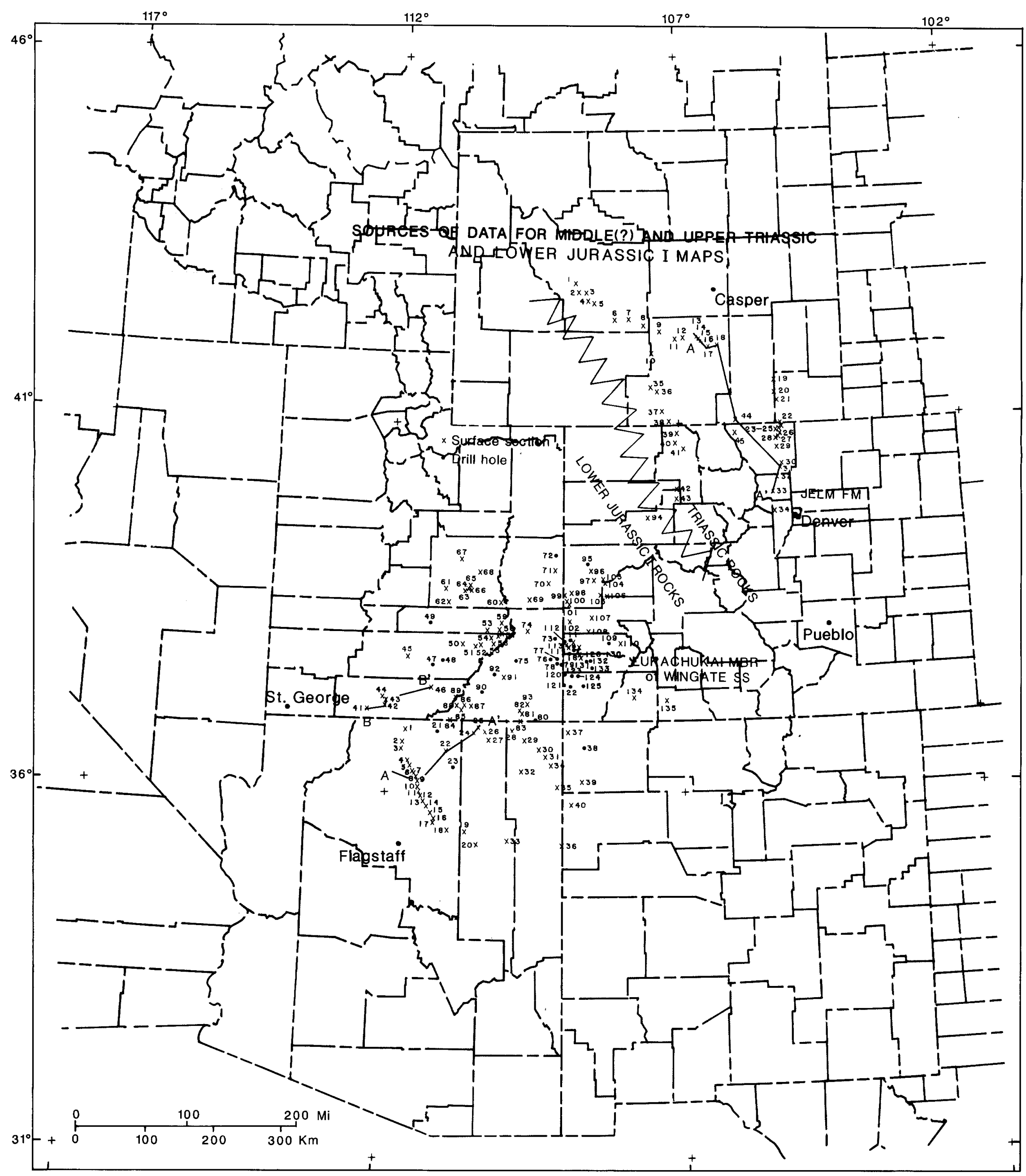

Fig. 12. Data points for Triassic and Lower Jurassic I maps showing lines of cross-section. See Tables 3 and 4 for location names and references. 


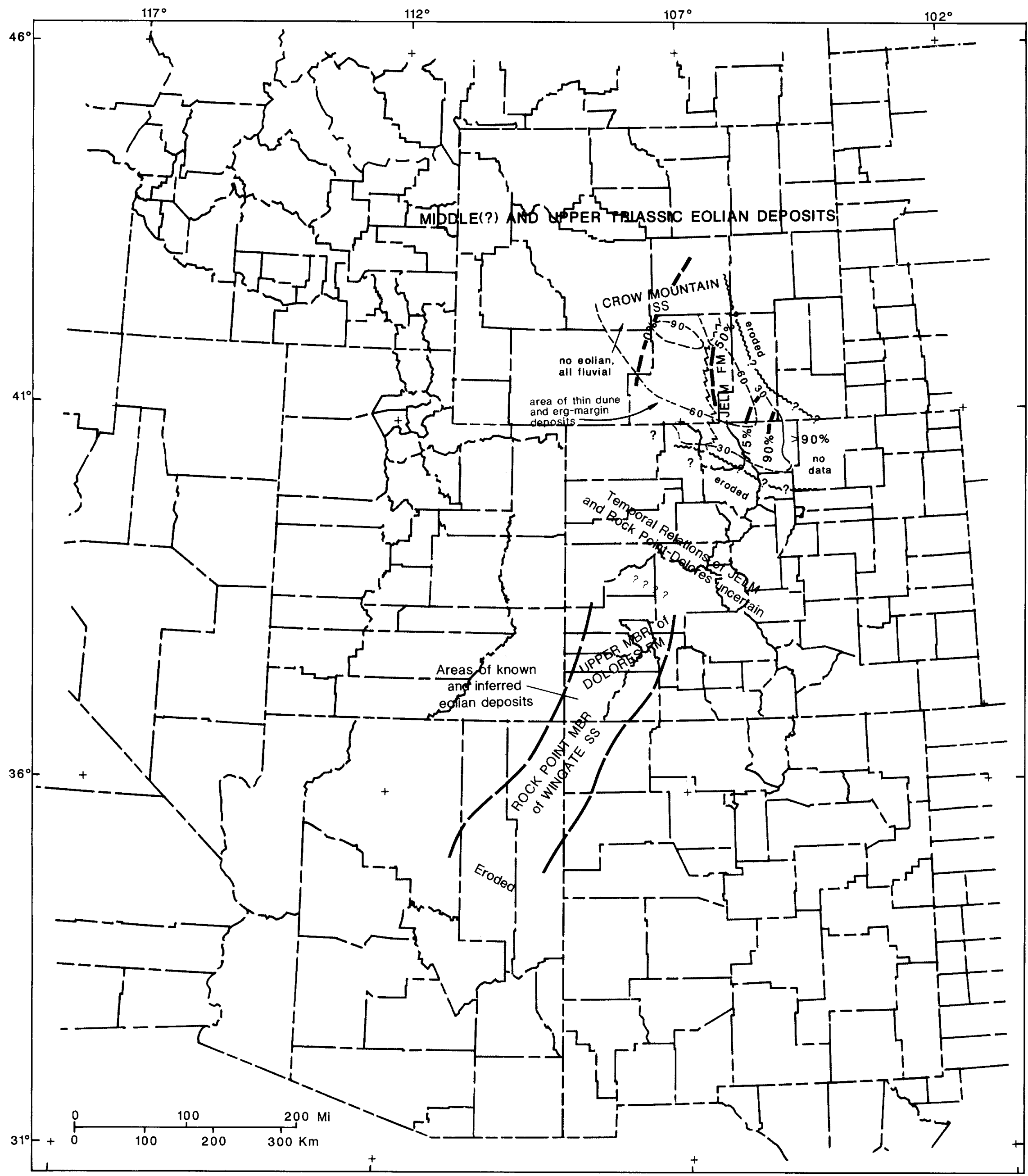

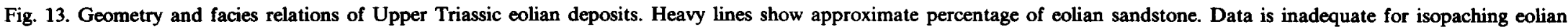
interval on Colorado Plateau. Isopach interval $30 \mathrm{~m}$. Solid lines where outcrops occur; dashed lines where interval in subsurface or removed by erosion. 


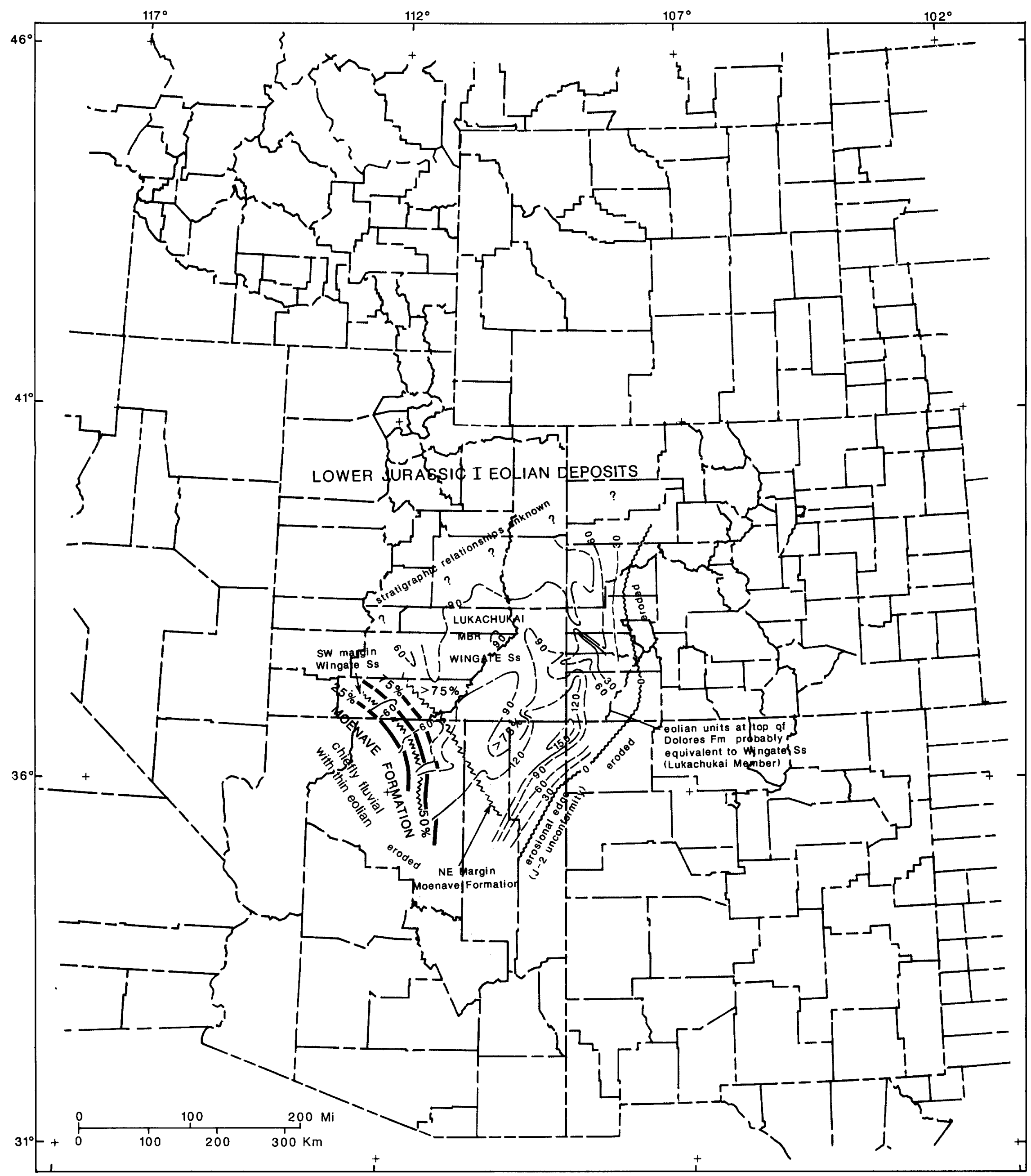

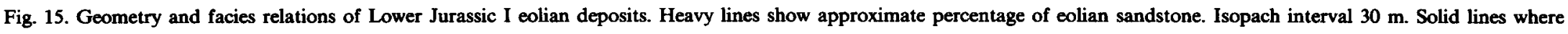
outcrops occur; dashed lines where interval in subsurface or removed by erosion. 

his figures show suspiciously eolian-looking features. Present data does not allow accurate isopaching of these eolian deposits but known stratigraphic information suggests extremely complex relations between eolian sandstone bodies and intercalated marine carbonates and redbeds of uncertain origin.

The Tensleep Sandstone and related units covered the Wyoming shelf, which was bordered to the east by a broad carbonate epicontinental sea and to the west by marine basins of the Cordilleran miogeocline (Fig. 4). The sand moved southward from an uncertain source (see Johansen, this volume) and abutted the edge of the Ancestral Rockies, which shed coarse arkosic debris into the southern edge of the ergs. Repeated transgressions and repressions of the Pennsylvanian sea and episodic uplift of the Ancestral Rockies caused the complex interfingering of eolian and non-eolian deposits at the erg margins. Some of the sand spilled southwestward along the west edge of the Uncompahgre uplift and formed dune fields or small ergs along the edge of the Pardox basin. Some sand drifted southward across the Piute platform of southern Utah into the Grand Canyon embayment and accumulated as a series of eolian deposits between marine strata (Fig. 7). Eolian deposits in the Atokan Manakacha Formation would be as old as or older than the eolian deposits in the Tensleep Sandstone to the north, the presumed direction of source.

\section{Wolfcampian eolian deposits}

Wolfcampian strata of the Western Interior contain vast erg deposits that stretch from the Mogollon Rim on the south to the Black Hills to the north-east. Eolian deposits have been documented in the Esplanade Sandstone (Blakey, unpublished data), Queantoweap Sandstone (Johansen, 1981), Cedar Mesa Sandstone and Elephant Canyon Formation (Loope, 1984), upper Weber Sandstone (Bissell and Childs, 1958), upper Casper Formation (Steidtmann, 1974), and upper Minnelusa Formation (Fryberger, 1984). These units likely once formed a single continuous sandstone body, which probably formed by the amalgamation of numerous ergs and dune fields. Each of the stratigraphic units is known to intertongue with fossiliferous Wolfcampian marine rocks (Fig. 7), though the youngest age of some of the eolian deposits is in doubt. For convenience, eolian deposits will be lumped into the Casper complex in Wyoming and north-central Colorado, the upper Weber Sandstone in the Uinta Mountains area, and the Cedar Mesa complex on the Colorado Plateau. Figure 8 is an isopach and facies map of the eolian-bearing interval of Wolfcampian age.

The Casper complex is a horseshoe-shaped sandstone body that wraps around the Lusk embayment and abuts the Ancestral Front Range to the south. Comprising parts of the upper Minnelusa Formation, upper Casper Formation, and Ingleside Formation (Fig. 7A and B), the erg thins from $100 \mathrm{~m}$ in thickness along the northnorthwest-trending Lusk embayment to an irregular-trending erosional edge across central Wyoming. Steidtmann (1974) has described the eolian characteristics and the relations with thin marine carbonates in the southern portion of the erg deposits; Fryberger (1984) has documented transgressive-regressive events and eolian, sabkha and marine relations for the northern portion of the area. Agatston (1954) provided the stratigraphic framework that documents the facies change to Wolfcampian marine carbonates and clastics (upper Minnelusa Formation and related rocks) along the western margin of the Lusk embayment. To the south, the Casper and Ingleside grade into coarse clastics of the upper Fountain Formation (Hoyt, 1963). The relations of the Casper with coeval Wolfcampian eolian deposits to the southwest is uncertain due to lack of data in southwest Wyoming. Most likely before post-Wolfcampian erosion removed the erg deposits across western Wyoming, a continuous eolian sheet spread across the Uinta Mountains area into central Utah.

The upper Weber Sandstone (Fig. 7C) is preserved along the flanks of the Uinta Mountains and eastward into northern Colorado (Fig. 8). Bissell and Childs (1958) have documented the eolian origin and stratigraphic framework of the unit. They have delineated a northeast-trending facies change through the central Uinta Mountains to marine siliciclastics to the west and traced a thin eolian tongue (Schoolhouse Tongue) south- 
east into the Central Colorado trough. The eolian tongue grades into and is enclosed by arkose of the upper Maroon Formation. Sparse subsurface data (Irwin, 1976) suggests that to the south of the Uinta Mountains the upper Weber Sandstone grades into the arkose along the flank of the Ancestral Uncompahgre Range and eolian sand spilled southwest around the uplift into the Cedar Mesa erg.

The Cedar Mesa complex, which includes parts of the Queantoweap Sandstone to the west and Esplanade Sandstone to the south, is a broad sheet that thickens to over $400 \mathrm{~m}$ thick in south-central and southwestern Utah (Fig. 7D and E). Stratigraphic and sedimentologic framework for this complex body has been provided by Blakey (1980), Johansen (1981), McKee (1982) and Loope (1984), although it should be pointed out that McKee did not recognize eolian deposits in the Esplanade Sandstone. The present configuration of the eolian-bearing sandstone describes a parabolic trough whose axis trends $\mathrm{N} 60^{\circ} \mathrm{E}$ across southern $U$ tah and thins rapidly on the northeast and southeast flanks. The erg deposits also undergo major facies changes along all of their margins. To the northeast and east the Cedar Mesa grades abruptly into the Cutler Formation (Baars, 1962: Campbell, 1979; Mack, 1979); southward along the Sedona arch the Esplanade Sandstone grades eastward into continental redbeds of the Hermit and Organ Rock Formations (Blakey, 1979, 1980); westward along the Cordilleran hingeline eolian deposits grade rapidly into Wolfcampian marine carbonate of the Pakoon and Elephant Canyon Formations (Baars, 1962; Irwin, 1976; McKee, 1982). Near the junction of the Green and Colorado rivers, the Elephant Canyon also contains eolian strata. The Cedar Mesa Sandstone thins across the Emery arch in central Utah to less than $30 \mathrm{~m}$ (Irwin, 1976) and should not be confused (Fig. 7D) with thick younger eolian sandstone of the overlying White Rim Sandstone (D. Baars, pers. commun., 1985). The Cedar Mesa Sandstone probably connects directly with the upper Weber Sandstone across and to the north of the Emery arch.

The Wolfcampian ergs were probably once continuous and are now separated geographically and structurally into three bodies (Fig. 8). Wolfcampian eolian deposits are confined to a trend defined by parallel northeast-trending lines, the western one running from southwest Utah to north-central Wyoming and the eastern one running from central Arizona to northeast Wyoming. The Casper Sandstone formed as a coastal and inland sand sea adjacent to marine deposits of the Lusk embayment and north of the Ancestral Rockies. Episodic changes in sea level caused the interdigitation of marine and eolian deposits across much of east-central Wyoming (Steidtmann, 1974; Fryberger, 1984). In the Laramie-Fort Collins area, narrow facies belts and abrupt facies changes reflect the complex interactions between uplift to the southwest, coastal dunes, and marine transgressive-regressive events to the east (Steidtmann, 1974).

The eolian deposits of the upper Weber Sandstone were sandwiched between the Ancestral Uncompahgre and Front Ranges and the Oquirrh Basin and Cordilleran miogeocline. As such, it was a triangular deposit that responded to uplift to the east and sea level changes to the west.

The Cedar Mesa Sandstone accumulated during a time of rapid subsidence accompanied by numerous sea-level changes and uplift in the Ancestral Uncompahgre Range. The southern Cordilleran miogeocline and Circle Cliffs trough were strongly negative but the influx of eolian sand was strong enough to keep the sea to the west much of the time. The rather straight margins of this complex unit suggest long-ranging tectonic controls on the erg margins (see Blakey, this volume).

\section{Leonardian I eolian deposits}

Ergs deposited during the lower Leonardian are restricted to the southern Colorado Plateau and are represented by major unconformity to the north (Figs. 2 and 7). The eolian sedimentology is provided by Blakey and Middleton (1983) and Vonderharr (1986) and the stratigraphic framework by Blakey $(1979,1980)$, and Blakey and Knepp (in press). The eolian deposit comprises parts of the Schnebly Hill and Yeso Formations and De Chelly Sandstone. It forms a broad 
horseshoe-shaped eolian body that wraps around the northern edge of the Holbrook Basin in eastern Arizona and related negative areas of western New Mexico (Fig. 9). Sandstones thicken towards the basin from a probable depositional edge along the Sedona Arch (Fig. 4) and a zone of facies change to Cutler Formation in the Four corners region and rapidly changes facies to marine and sabkha carbonate and redbed deposits in basinal areas. The erg deposits are thickset, about $180 \mathrm{~m}$ thick, near the sharp facies change toward the basin. The rocks are firmly dated by the interbedded Fort Apache Member of the Schnebly Hill Formation (Blakey and Knepp, in press) although exact temporal correlations within this complex body, especially with the Mesita Blanca Sandstone Member of the Yeso Formation in New Mexico are yet to be solved. It is suggested here that the oldest eolian deposits in this sequence are contained in the Mesita Blanca Sandstone of New Mexico and lower Schnebly Hill Formation of the western Mogollon Rim, and that the youngest eolian deposits are in the upper part of the De Chelly Sandstone in northeast Arizona and upper Schnebly Hill formation in the Mogollon Rim. We also suggest, based on physical stratigraphy and cursory sedimentologic observations, that a thin eolian tongue near the top of the Organ Rock Formation in the upper Lake Powell region of southeastern Utah may be a northward extension of the De Chelly Sandstone.

The De Chelly and related formations were deposited during a period of erosion to the north and abrupt subsidence along the southern Colorado Plateau. It appears that the period of erosion to the north saw the mobilization of large amounts of sand from older Pennsylvanian and Permian ergs and that the sand was fed southward until it crossed the Sedona Arch and encountered rapid subsidence along the Holbrook basin. Here the sand was trapped between a broad slightly positive region to the north and marine and sabkha conditions in the negative area to the south (Blakey and Middleton, 1983). During periods of low sea level and/or extensive influx of sand from the north, the erg prograded southward across the coastal plain. Rises in sea level caused transgression and destruction of the ergs, which resulted in an unconformity overlain by sabkha and marine redbeds and carbonate.

\section{Leonardian $I I$ eolian deposits}

The middle Leonardian eolian complex is likewise restricted to the southern Colorado Plateau and includes the bulk of the Coconino Sandstone and coeval Glorieta Sandstone (Fig. 10). The Coconino has long been considered eolian (McKee, 1933) but details concerning eolian sedimentology remain largely unpublished. The Coconino perhaps most closely approaches the stereotype of the layer-cake, monotonous quartzarenite eolian deposit. The unit displays less intertonguing and facies changes than most other late Paleozoic erg deposits and, in many places, is chiefly large-scale, cross-stratified sandstone; however, as will be discussed, there are exceptions to the above. The age of the Coconino and Glorieta is based on stratigraphic position; it overlies and intertongues with the De Chelly Sandstone of Yeso age and underlies the upper Coconino and White Rim Sandstones which intertongue with the marine Toroweap Formation. The above stratigraphic relations are best exposed along the west side of the Sedona Arch and are thoroughly documented by Rawson and Turner-Peterson (1980).

The Coconino thickens from a feather edge along the Utah-Arizona border to nearly $300 \mathrm{~m}$ in the central Mogollon Rim (Figs. 7E and 10). East of the Sedona Arch, the lower and upper Coconino are inseparable and isopachs are combined. The north feather edge is probably depositional; it was modified by post-Coconino erosion especially in northeastern Arizona across the Defiance Plateau. The erg-bearing sequence is exposed across much of central and northern New Mexico in the Glorieta Sandstone but south and east of the Colorado Plateau little sedimentological data is available and it is uncertain how much of the formation is eolian.

In the central and eastern Mogollon Rim, the typical Coconino grades into alternating small- to medium-scale cross-stratified sandstone and intercalated wavy bedded to horizontally stratified sandstone. Though this eastern facies has been considered to be of marine origin by some workers, 
Blakey (1986) documented the presence of small eolian dunes and sabkha and/or wet interdune deposits for this facies.

The Coconino Sandstone formed downwind from eroding eolian and marine rocks to the north. Reworked eolian sand moved southward across the featureless terrain of central and northern Utah until it encountered an area of subsidence associated with the last stages of the Holbrook Basin. Some areas in the Mogollon Rim were close enough to marine areas to the south to form interbedded sabkha and coastal dune deposits. However, most of the Coconino and at least some of the Glorieta were deposited in an inland erg far removed from direct marine influence as shown by a dominance of deposits formed by large dunes with few wet interdune deposits.

\section{Leonardian III eolian deposits}

The latest Leonardian ergs, possibly partially Guadalupian in age occur in widely separated areas of the Colorado Plateau and north-central Colorado. Correlation of these two eolian complexes is considered somewhat tentative but is based on relations with adjacent marine rocks and regional correlation as shown by Rascoe and Baars (1972). The White Rim Sandstone and upper Coconino Sandstone form the western erg deposits and the Lyons Sandstone forms the eastern one (Fig. 11). Eolian deposits have also recently been identified to the east in the Leonardian and Guadalupian of west Texas and adjacent New Mexico (Nance, this volume). At present it is uncertain as to how these deposits related to the major erg systems to the west. The Lyons Sandstone was carefully documented to be of eolian origin by Walker and Harms (1972). Stratigraphic relations were provided by Thompson (1959) and Hoyt (1963). The Lyons forms a parabolic-shaped deposit in which the trough of the parabola trends east-northeast (Fig. 11). The center of the unit is about $60 \mathrm{~m}$ thick. To the north the Lyons intertongues with marine carbonate and sabkha redbeds of the Owl Canyon and Satanka Formations (Figs. 2 and 7B). Eastward and southeastward it grades into marine carbonates and redbeds and southwestward it intertongues with the upper
Fountain Formation. The west edge of the parabola is truncated by the present-day Front Range, though it seems probable that the Lyons once extended several tends of kilometers west across the edge of the Ancestral Front Range.

The White Rim and upper Coconino Sandstone complex is confined to the west of the Sedona and Monument Arches and extends from central Utah to the Mogollon Rim in Arizona. Sedimentologic data are provided by Baars and Seager (1970), Rawson and Turner-Peterson (1980), and Kamola and Chan (this volume). Stratigraphic data are provided by Irwin (1976) as well as the above authors. The eastern feather edge of the White Rim follows the present course of the Colorado River southward into Arizona; however, in Arizona the upper Coconino extends eastward to an area across the Sedona Arch where it can no longer be separated from the lower Coconino and is therefore included with it on Fig. 10. The White Rim Sandstone averages about $60 \mathrm{~m}$ in thickness across much of its extent but thickens to over $250 \mathrm{~m}$ in the Circle Cliffs trough (Figs. 7D and 10). Baars and Seager (1970) pointed out that the eastern margin is not a true feather edge but rather the unit thins to less than $10 \mathrm{~m}$ and grades eastward into redbeds of the Organ Rock Formation. In some areas this edge has been modified by preTriassic erosion. The White Rim and upper Coconino everywhere grade westward through a zone of complex facies change into marine carbonate and sabkha evaporite and sandstone of the Toroweap Formation (Fig. 7D and E). This change is well documented by Irwin (1976) and Rawson and Turner-Peterson (1980). The facies change follows the west edge of the Sedona Arch from the Mogollon Rim northward to near Page, Arizona and then swings northwestward along the Kaibab Arch; then it swings back to the northeast near and parallel to the west edge of the Colorado Plateau (Fig. 11). The White Rim Sandstone is truncated by erosion along the northwest-trending Emery Arch in central Utah (Rascoe and Baars, 1972; Irwin, 1976).

We have field-checked some of the reports of intertonguing of the White Rim and upper Coconino with the overlying Kaibab Formation. In areas that we have field checked, we have not 
been able to document such intertonguing; however, in many areas of north-central Arizona and south-central Utah, the Kaibab is very sandy and the White Rim, Toroweap, and Kaibab are very difficult to separate on outcrop, much less the subsurface. Although regional stratigraphic data may suggest that a White Rim-type sand body lay to the east of the Kaibab sea, such an occurrence has not yet been clearly documented.

The White Rim and upper Coconino Sandstones were deposited by a coastal sand sea that bordered the Toroweap sea. Intertonguing with the Toroweap was caused by changes in sea level coupled with changes in sand supply. The Sedona and Monument arches formed an eastern barrier to eolian deposition and preservation (see Blakey, this volume). The erg systems were apparently fed by eolian sand reworked from the north.

The Lyons was deposited between mountains, alluvial fans, and a coastal plain. The erg expanded and contracted in response to tectonism, sea-level change and sand supply. The sand may have been reworked from older ergs to the north or derived from coeval alluvial fan deposits.

\section{Upper Triassic and Lower Jurassic eolian deposits}

\section{Introduction}

The latest Permian and most of the Triassic lack recognized eolian deposits. Eolian deposition was renewed in the Late Triassic and culminated with major eolian sedimentation in the Early Jurassic (Fig. 2). We recognize three erg-bearing intervals: Jelm Formation, Wingate Sandstone and Navajo Sandstone and related units, which include the Nugget and Aztec Sandstones.

\section{Upper Triassic eolian deposits}

The Jelm Formation is exposed in south-central Wyoming and north-central Colorado. The eolian deposits occur in both members of the Jelm as recognized by Pipiringos (1972) and Pipiringos and O'Sullivan (1976). However, neither of the above papers considered the origin of the Jelm Formation. An eolian origin for part of the formation is based on unpublished information gathered by Peterson. Peterson's field work has confirmed an eolian origin for the large-scale, cross-stratified sandstone shown in columns published by Pipiringos (1972) and Pipiringos and O'Sullivan (1976). Our maps show the thickness of the Jelm Formation based on the above sections and the distribution and percentage of eolian sandstone as inferred from the sections (Table 3) and Peterson's preliminary field work. Given the relatively sparse data, the maps and the following discussion must be considered preliminary.

Based primarily on regional stratigraphy, the Jelm Formation is assigned a Late Triassic age (Pipiringos and O'Sullivan, 1978). No comprehensive discussion of its origin or tectonic setting presently exists; however, the regional isopach and facies map (Figs. 12 and 13) provides some background for preliminary discussion. The erg deposits are apparently confined to the southeast portion of the Jelm Formation (Fig. 14) in southcentral Wyoming. The area roughly coincides with that of Permian erg deposition (Fig. 8). A large fluvial plain lay to the west of Jelm erg sedimentation and possibly served as a partial source of the sand in the erg. As the south and east margins of the unit are truncated by the $\mathrm{J}-2$ unconformity, no information is available concerning its original extent. Clearly this unit is in need of major regional study.

The Rock Point Member of the Wingate Sandstone contains eolian deposits throughout most of its extent. Although equivalent to the upper part of the Chinle Formation, Harshbarger et al. (1957) included the Rock Point in the Wingate Sandstone because of supposed intertonguing between the Rock Point and Lukachukai Members. Later work has failed to confirm intertonguing and instead has suggested the presence of an unconformity, the $\mathrm{J}-0$, between the two units (Pipiringos and O'Sullivan, 1978; Peterson and Pipiringos, 1979). Nevertheless, the Rock Point and Lukachukai are still officially considered members of the Wingate Sandstone, the former Upper Triassic and the latter, Lower Jurassic. Given that the Rock Point Member is thickest in the southern Four Corners region and that the Chinle Formation is beveled to successively older units to the west by the J-0 unconformity, it seems likely that the Rock Point 


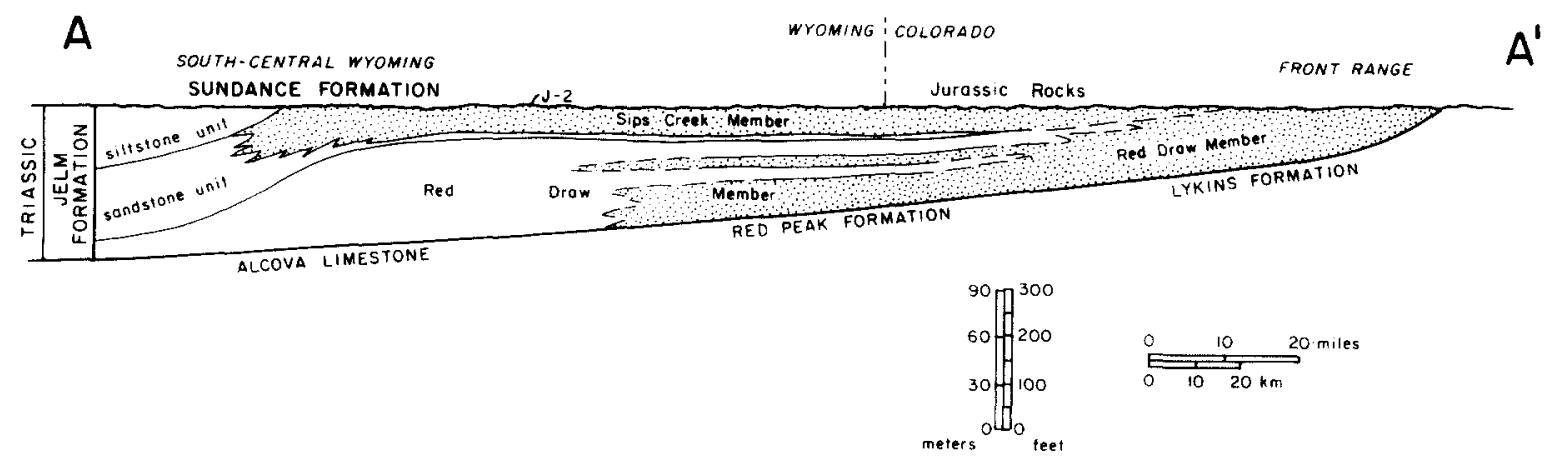

Fig. 14. Restored cross-section showing Upper Triassic eolian deposits in Jelm Formation. Location shown on Fig. 12.

Member represents the youngest Triassic deposits on the Colorado Plateau. It can perhaps be inferred that youngest Rock Point strata are nearly conformable with overlying Lukachukai units and that it is no coincidence that this is where some of the thickest Triassic eolian deposits occur.

The thickest Upper Triassic rocks of the Western Interior occur across the northern edge and along the east flank of the Defiance upwarp. Thus this long-ranging positive area was a basin during the Late Triassic. This area lies along the Zuni trend as defined by Blakey (this volume). It was in this low area that the only known Triassic eolian deposits on the Colorado Plateau were deposited. In southwestern Colorado, these rocks are assigned to the upper member of the Dolores Formation (Blodgett, 1984). Eolian deposits consist of cross-stratified sandstone of dune origin and laminated to hummocky sandstone of sand-sheet origin, both intercalated with fluvial and lacustrine deposits (Harshbarger et al., 1957; Stewart et al., 1972; Blodgett, 1984). We are unable to construct either isopach maps or percentage-of-eolian-strata maps from existing literature or unpublished information known to us. Figure 13 shows a rough outline of known and inferred eolian strata in Upper Triassic rocks of the Four Corners region. Temporal correlation with eolian strata of the Jelm Formation to the north is possible but unproven.

\section{Lower Jurassic I erg deposits}

The Lower Jurassic Wingate Sandstone forms a persistent vertical cliff throughout the canyonlands of southeastern Utah and adjacent Arizona and Colorado. Plagued by a series of miscorrelations, especially in northwestern New Mexico, the presently accepted eastern margin is shown on Fig. 15. Only the southwestern and eastern margins of eolian rocks, where the Wingate intertongues with the Dinosaur Canyon Member of the Moenave Formation (Fig. 16 and Table 4), are exposed and reasonably well understood. The nature of the formation to the west, northwest, and northeast is uncertain although we discuss our inferences later in this paper. As discussed above, the present terminology of the Wingate Sandstone is somewhat confusing. North, northwest and west of Kayenta, Arizona, the Wingate Sandstone unconformably overlies the Upper Triassic Chinle Formation and in this region the formation is undivided. East, southeast and south of Kayenta, the formation includes the lower Rock Point Member which is equivalent to the upper Chinle Formation (Harshbarger et al., 1957). In this region the upper part of the formation (the Wingate Sandstone, undivided to the north) is assigned to the Lukachukai Member. Our isopach and facies map (Fig. 15) concerns only the Wingate Sandstone (undivided) and Lukachukai Member of the Wingate Sandstone; the Rock Point Member of the Wingate Sandstone (Chinle equivalent) is not included. An eolian origin for most of the Wingate Sandstone has long been accepted; however, the details of eolian sedimentation have yet to appear in the literature. Tabular cosets 2-5 m thick comprised of trough sets filled with climbing wind-ripple lamination have been observed at several local- 


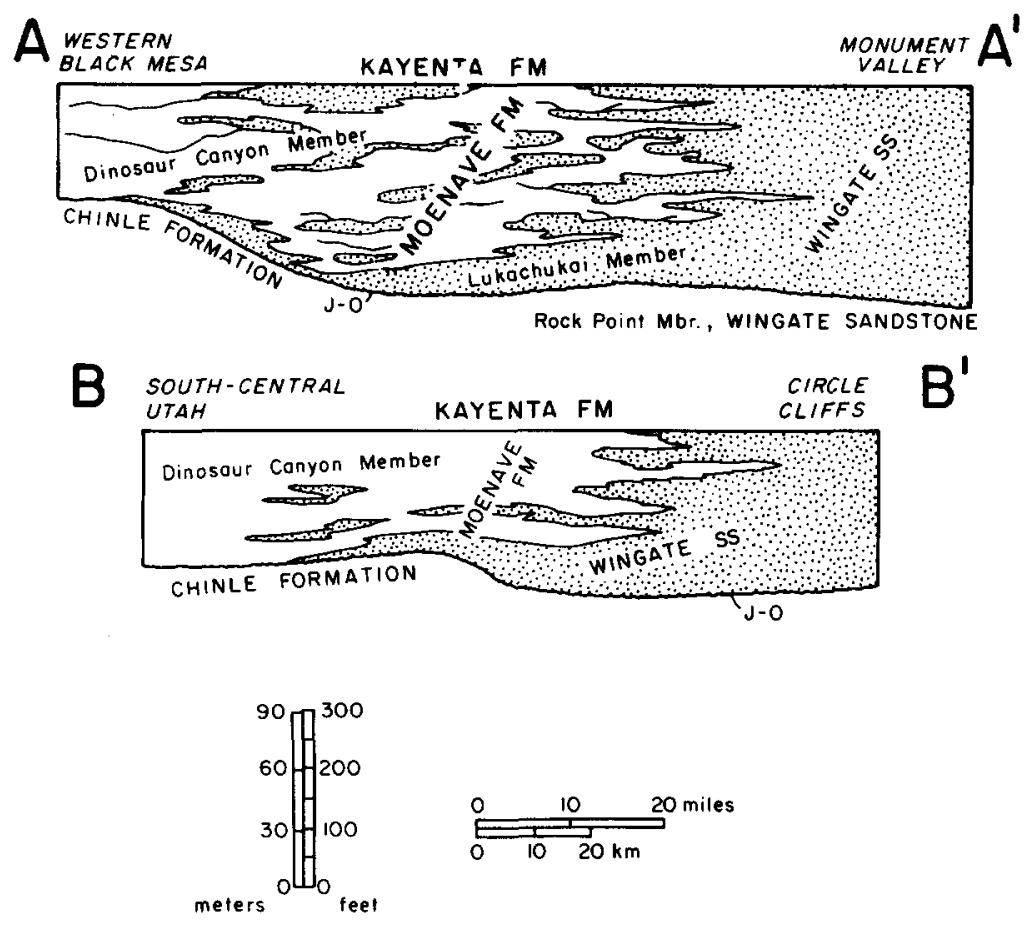

Fig. 16. Restored cross-sections showing Lower Jurassic I eolian deposits in Lukachukai Member of Wingate Sandstone and Dinosaur Canyon Member of Moenave Formation. Locations shown on Fig. 12.

ities across the Colorado Plateau. We have been able to confirm an eolian origin at a number of locations across the Colorado Plateau but are unable to present a detailed regional summary of eolian history. In northeastern Arizona the Wingate Sandstone (Lukachukai Member) contains persistent internal erosional surfaces probably correlative to fluvial events to the south. This would suggest several episodes of erg formation and destruction. To the north in Utah and Colorado no such surfaces have yet been identified. No studies document vertical changes in the Wingate nor present consistent information on the nature of the upper contact with the overlying fluvial Kayenta Formation.

The age of the Wingate Sandstone has long been in doubt but the most recent age assignment based on scarce paleontological data and regional stratigraphy suggests it is Early Jurassic (Sinemurian to Pliensbachian) (Pipiringos and O'Sullivan, 1978; Peterson and Pipiringos, 1979). The Wingate Sandstone unconformably overlies Upper Triassic rocks except where the formation is divided into two members. There the Triassic-Juras- sic boundary lies between the Lukachukai and Rock Point Members; the erg deposits as included on Fig. 15 everywhere unconformably overlie Triassic rocks (see also Fig. 2).

The Wingate Sandstone forms a broad sandstone sheet that thickens and thins slightly across the southern, central and eastern Colorado Plateau. The unit is broadest in a southwest-northeast direction and in general, isopach trends parallel this. The erg deposits are thickest along a northeast-trending broad trough that lies adjacent to the southeastern erosional margin. The rapid thinning along this margin reflects the truncation of the erg beneath the $\mathrm{J}-2$ unconformity (Pipiringos and O'Sullivan, 1978). We have no idea how far eastward the erg once extended. The erg deposits show local thinning and thickening in the Salt Anticline region of eastern Utah and western Colorado. Whether this is because of syn-depositional tectonic movement on the salt structures or postdepositional uplift and erosion is unknown. The Wingate displays local thick areas slightly east of and parallel to the present Colorado River and in the northwestern Circle Cliffs area. It thins across 
the southern Monument Uplift and across the northern Kaibab Uplift. Nothing is known about the erg to the west and north of its area of outcrop in southeastern Utah. We offer three untested hypotheses concerning its margins in these directions: (1) the eolian deposits thin to an erosional or depositional edge; (2) they merge with the Navajo Sandstone because of northwestward pinch-out of the intervening Kayenta Formation; and (3) the eolian sandstones undergo facies change with fluvial and sabkha redbeds as can be documented along its present southwestern margin; our discussion of the Navajo-Nugget Sandstone in the next section favors the third hypothesis.

The southwestern margin of the Wingate is exposed along a line of cliffs that trend from near Holbrook, Arizona to Zion National Park, Utah. Figure 16 shows restored cross-sections across the erg margin. Edwards (1985) documented fluvialeolian interactions in north-central Arizona and work in progress by Lars Clemmensen and Henrik Olsen of the University of Copenhagen in conjunction with Blakey is studying the erg margin along the Vermilion Cliffs. These studies document an initial erg progradation southwest to a line from north-central Arizona to south-central Utah (Fig. 16). Fluvial deposits, chiefly of ephemeral sheet-flood and stream-flood origin, encroached upon and reworked the erg margin. The fluvial deposits, the Dinosaur Canyon Member of the Moenave Formation, extended as far northeastward as a line from the Defiance Plateau in Arizona to west of the Circle Cliffs in Utah (Figs. 15 and 16). Most stratigraphic work has placed the lower southwest extension of the erg in the Wingate Sandstone and the interval of alternating fluvial and eolian deposition in the Dinosaur Canyon Member of the Moenave Formation.

The Wingate Sandstone is in need of additional sedimentologic and stratigraphic study. Little is known about regional sedimentologic trends and history of erg development. The isopachs (Fig. 15) and cross sections (Fig. 16) show some relations to regional syn-depositional tectonic patterns (Blakey, this volume), especially the southern margin, which closely parallels the Zuni lineament of Kelley (1955). Apparently the northeast margin of northwesterly flowing streams in the Moenave Formation was somehow influenced by this line.

\section{Lower Jurassic II eolian deposits}

Eolian strata of late Early Jurassic age depicted on the data base and isopach maps (Figs. 17 and 18) probably formed the largest eolian deposits in North America. These rocks include such wellknown units as the Aztec Sandstone (Nevada and southeastern California), the Glen Canyon Sandstone (northwestern Colorado and northeastern Utah), the Navajo Sandstone (northern Arizona, western Colorado, southern and central of Utah), and the upper member of the Nugget Sandstone (southeastern Idaho, northern Utah and Wyoming). Eolian strata in southern Arizona that are thought to correlate at least approximately with these units are included in several formations, each of which is restricted to one or a few of the mountain ranges in the Basin and Range Province. These includes the Ali Molina, Mount Wrightson, and Sil Nakya Formations, the Cobre Ridge Tuff, and the Ox Frame Volcanics (Bilodeau and Keith, 1986). Data used in preparation of the isopach map are included in Table 5 and the distribution of data points is shown on Fig. 17. These beds are here considered late Early Jurassic in age (Pliensbachian and Toarcian Ages; Peterson and Pipiringos, 1979).

Not included in this study are quartzites of Early Jurassic age in the southern part of western Nevada that may also be eolian and that may correlate with late Early Jurassic eolian units farther east in the Western Interior. Although highly metamorphosed, cross-bedding in the quartzites can still be recognized even though finer details such as grading, ripple cross-laminations, details of the laminations, and grain shape have been largely or entirely obliterated, making it difficult to find conclusive evidence of the mode of deposition. Proffett and Dilles (1984) considered Jurassic quartzites (their quartzitic sandstone) of the Singatsee Range (sect. 27, T13N, R24E, Lyons County, Nevada) eolian in origin but a field check revealed only poorly suggestive evidence such as the moderately large thickness (as much as $1.5 \mathrm{~m}$ ) of a small number of sets and the relatively pure 


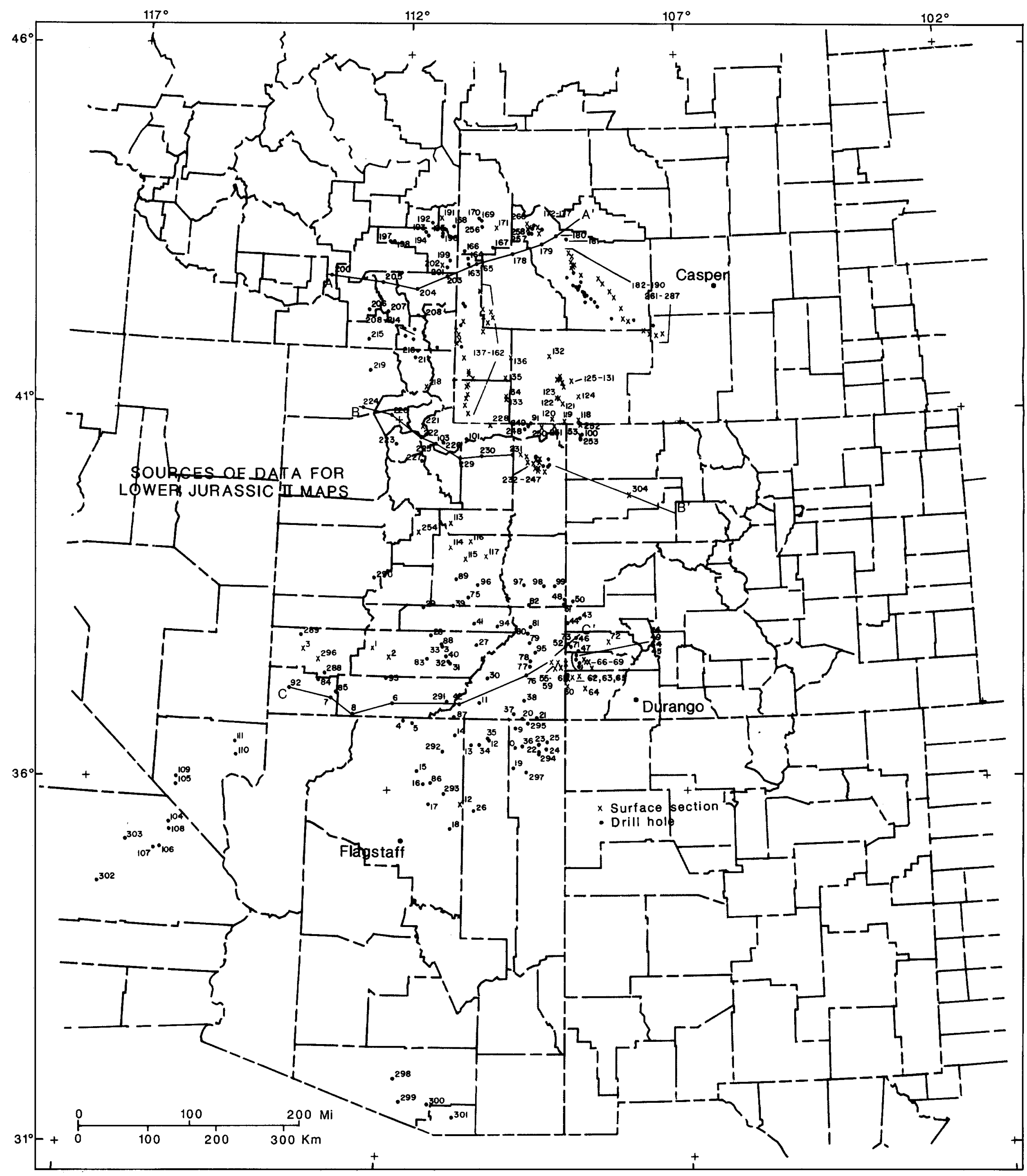

Fig. 17. Data points for Lower Jurassic II maps also showing lines of cross-section. See Table 5 for location names and references. 


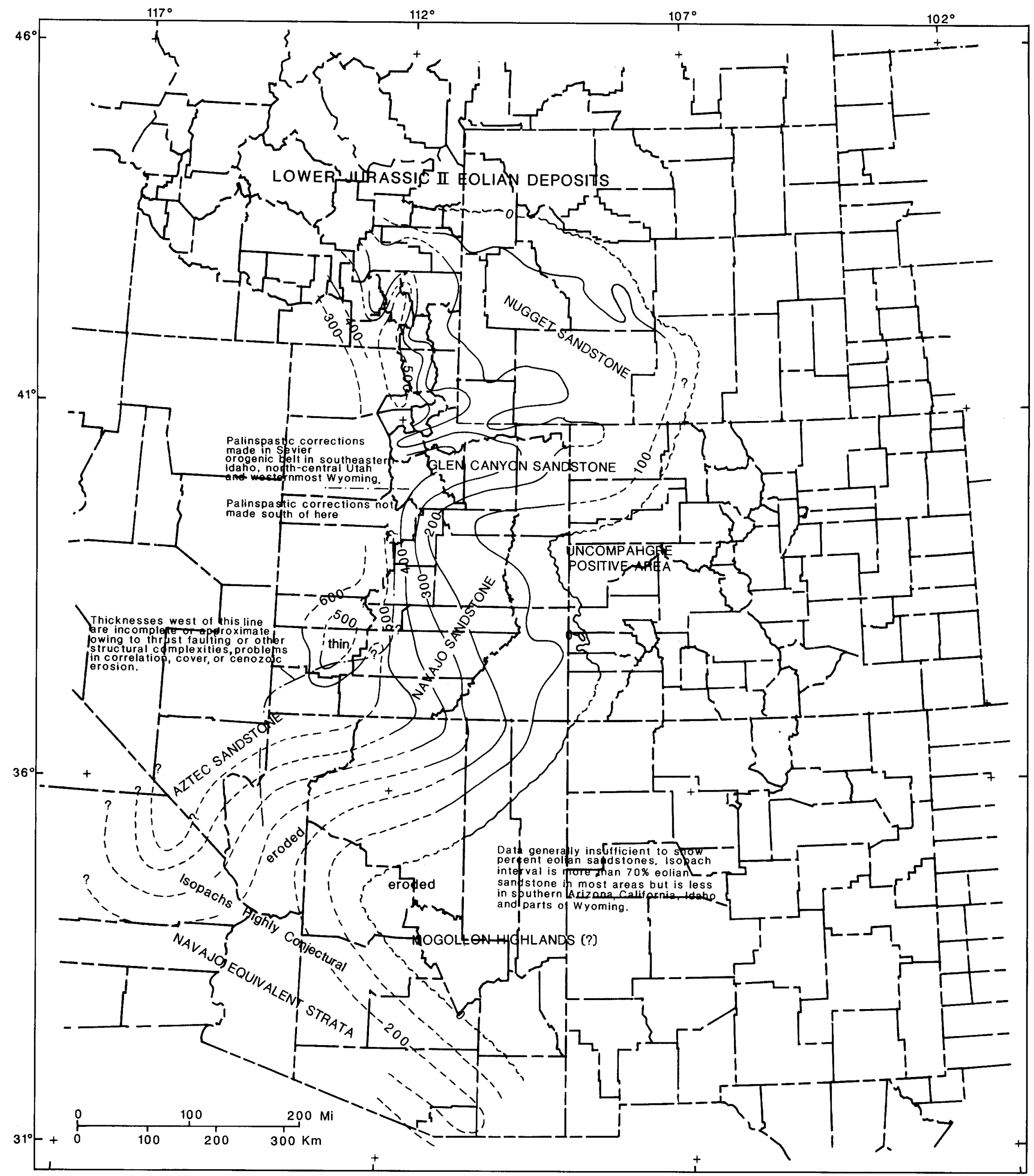

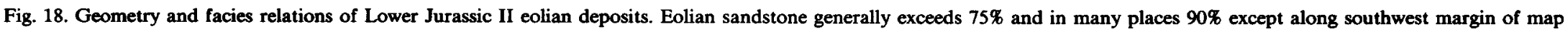
where facies relations are complex and variable. Isopach interval $100 \mathrm{~m}$. Solid lines where outcrops occur; dashed lines where interval in subsurface or removed by erosion. 


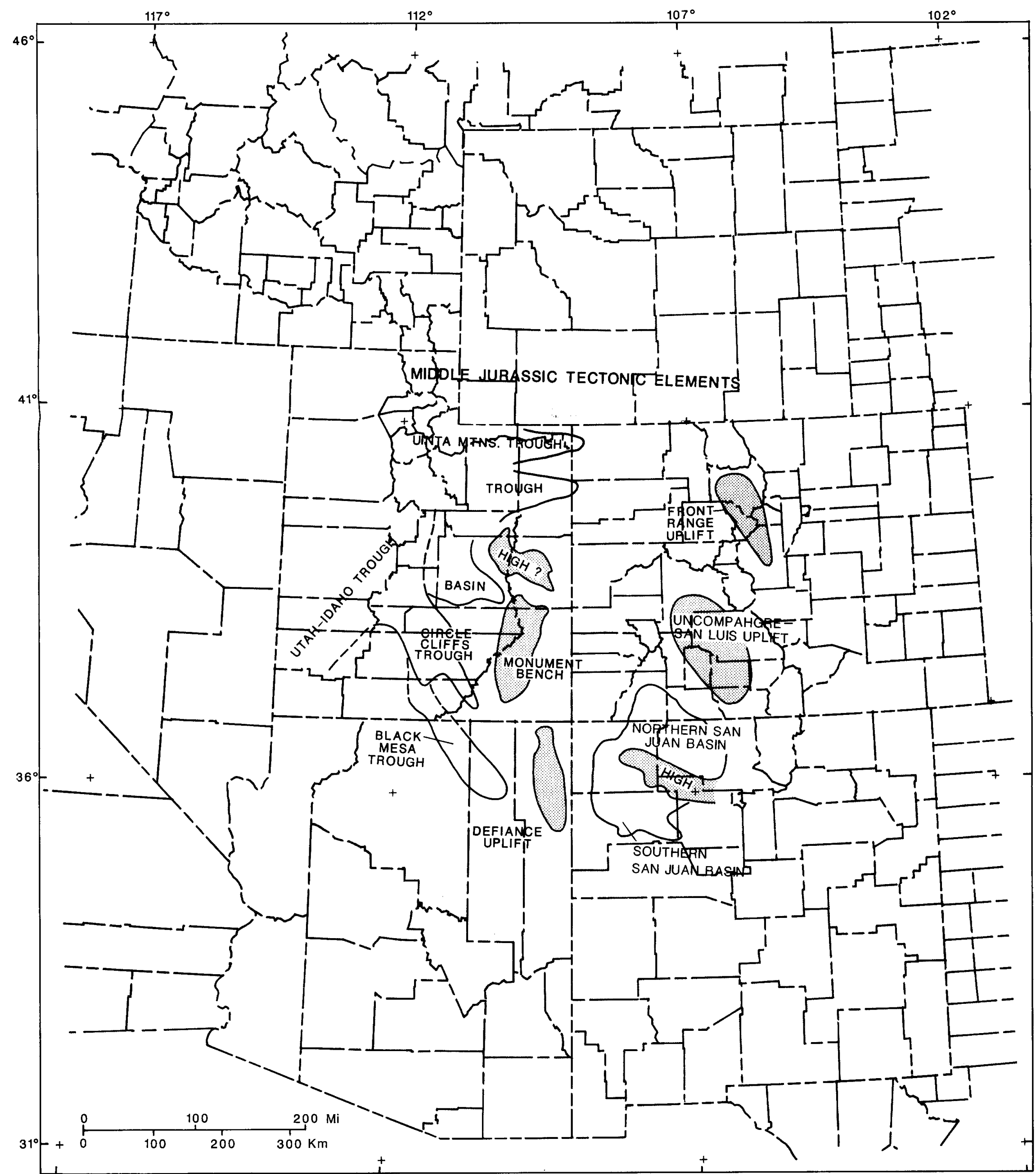

Fig. 20. Generalized Middle Jurassic tectonic elements that influenced eolian sedimentation in the Western Interior. Boundaries are approximated and varied through time. 



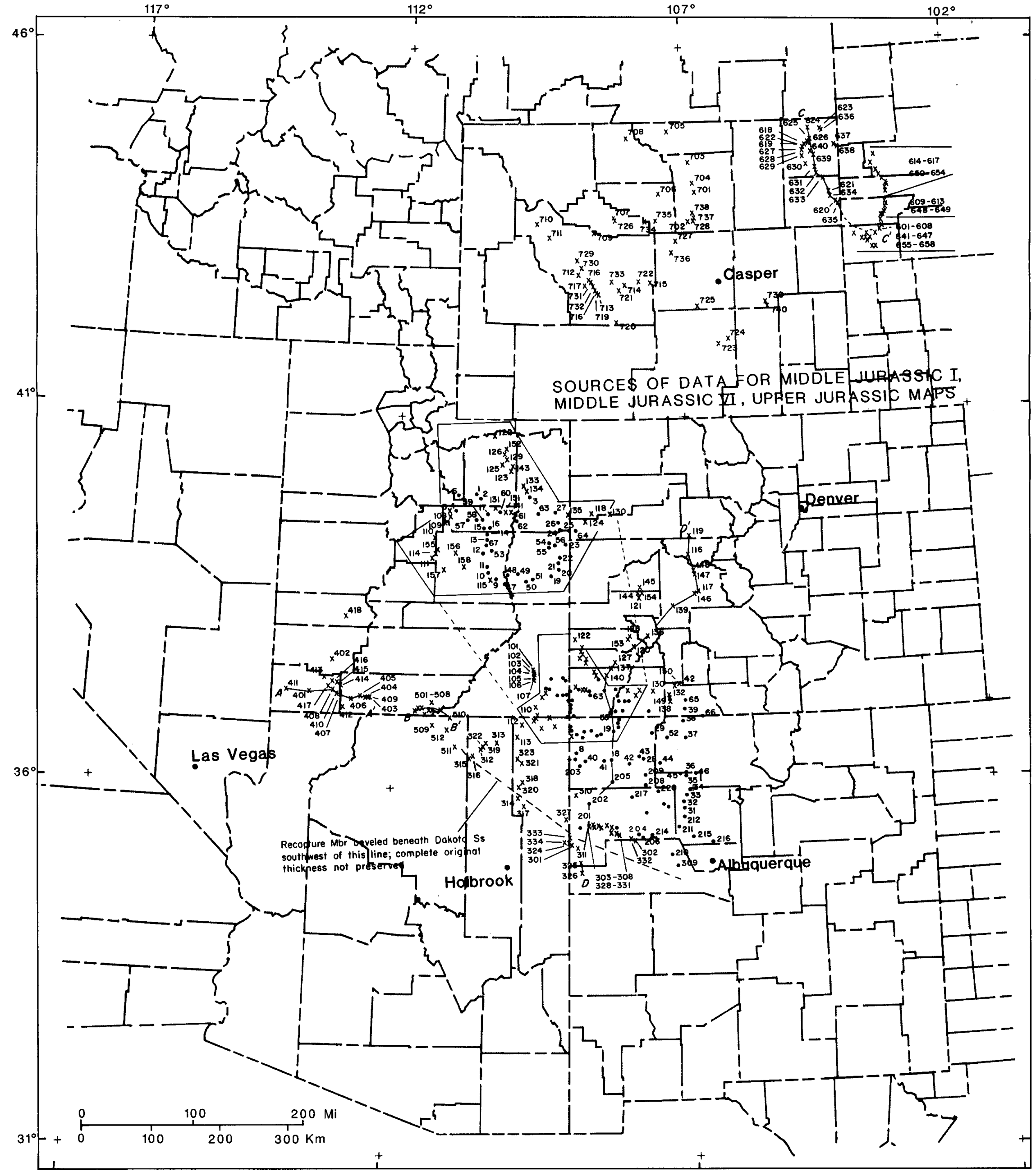

Fig. 21. Data points for Middle Jurassic I, VI, and Upper Jurassic maps also showing lines of cross section. See Table 6 for location names and references. 


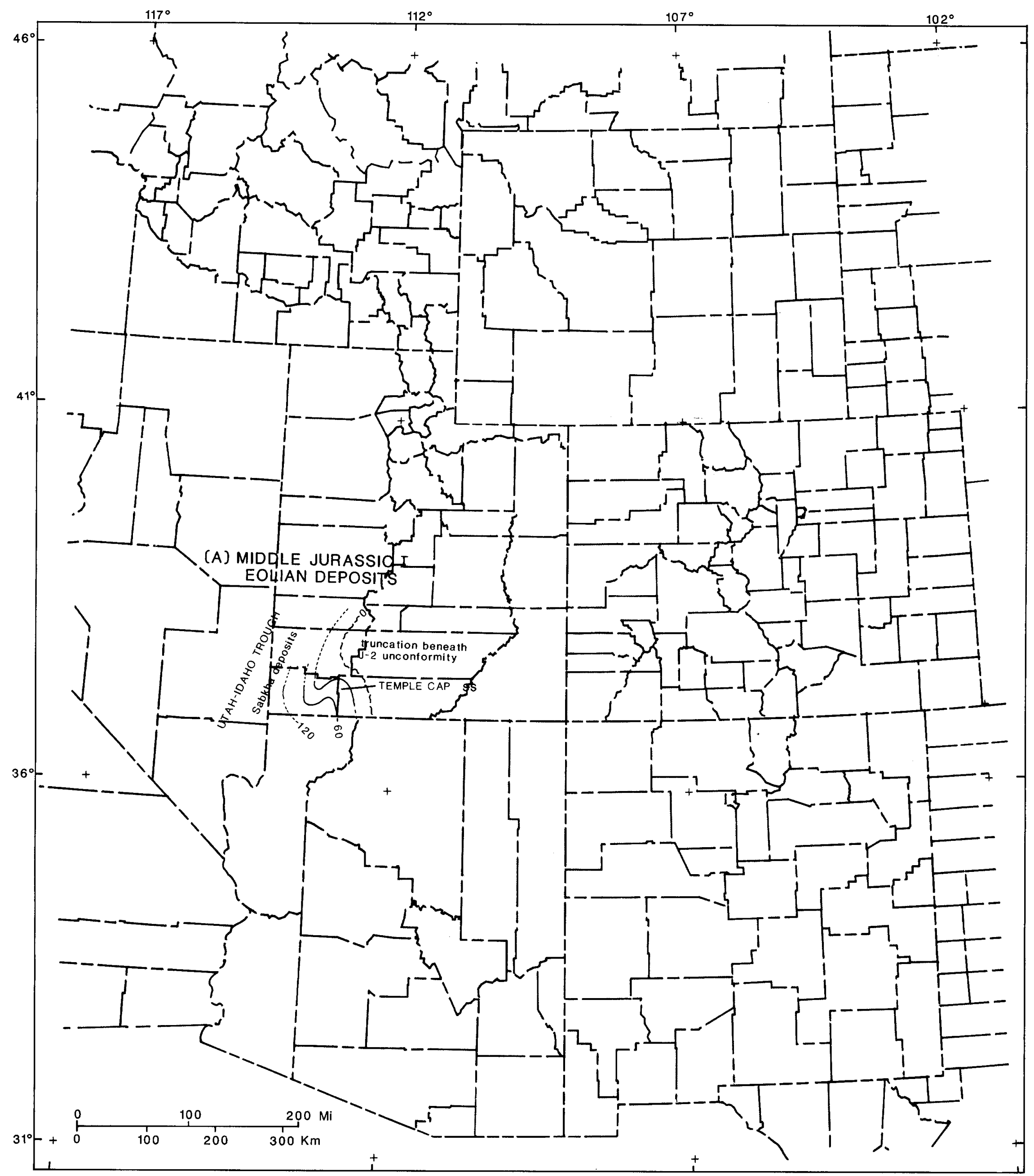

Fig. 22A. Geometry of Middle Jurassic I eolian deposits in the Temple Cap Sandstone. Isopach interval $30 \mathrm{~m}$. Solid lines where outcrops occur; dashed lines where interval in subsurface or removed by erosion. 


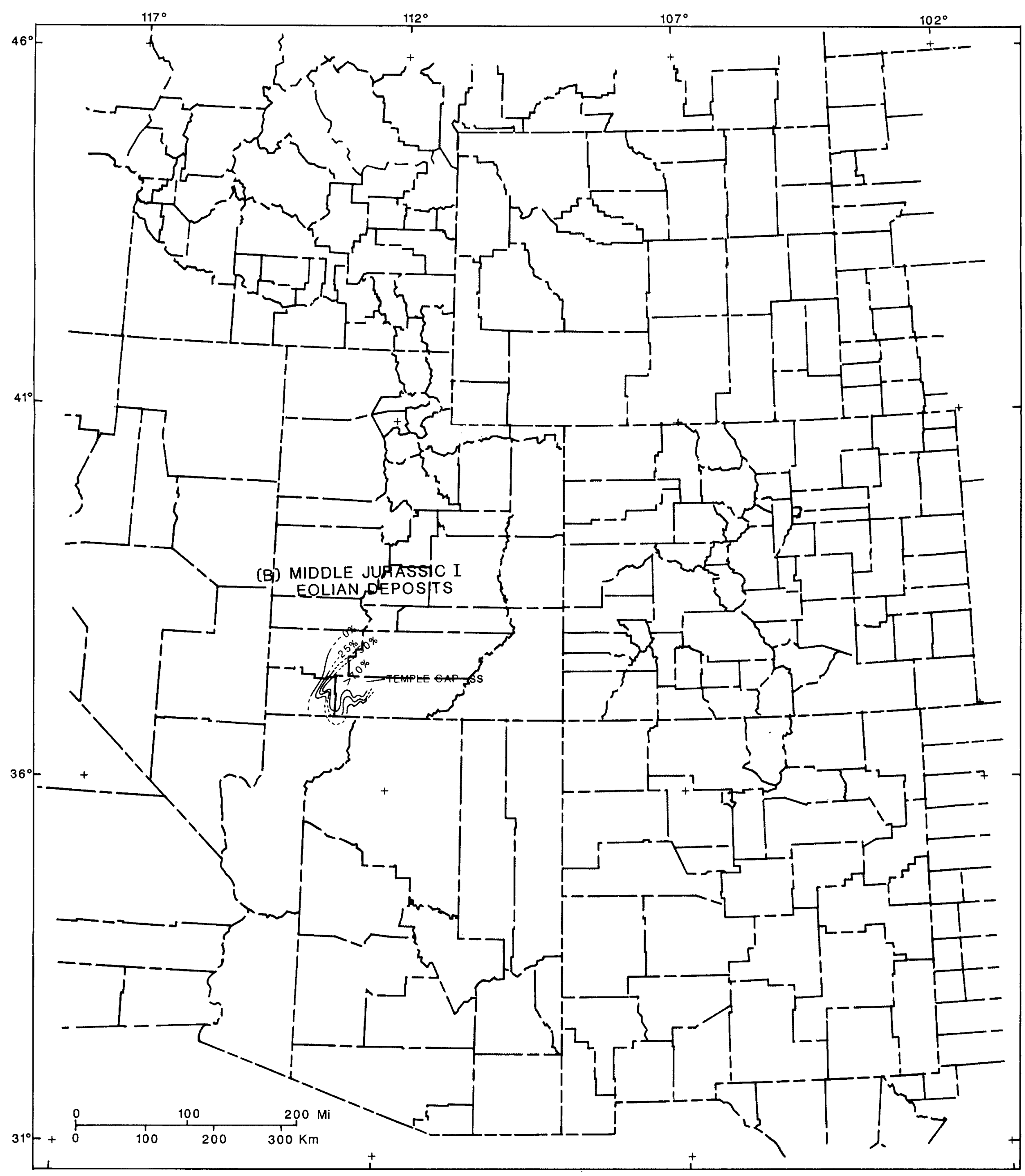

Fig. 22B. Facies relations of Middle Jurassic I eolian deposits in the Temple Cap Sandstone. Isopach interval $30 \mathrm{~m}$. Solid lines where outcrops occur; dashed lines where interval in subsurfaces or removed by erosion. 



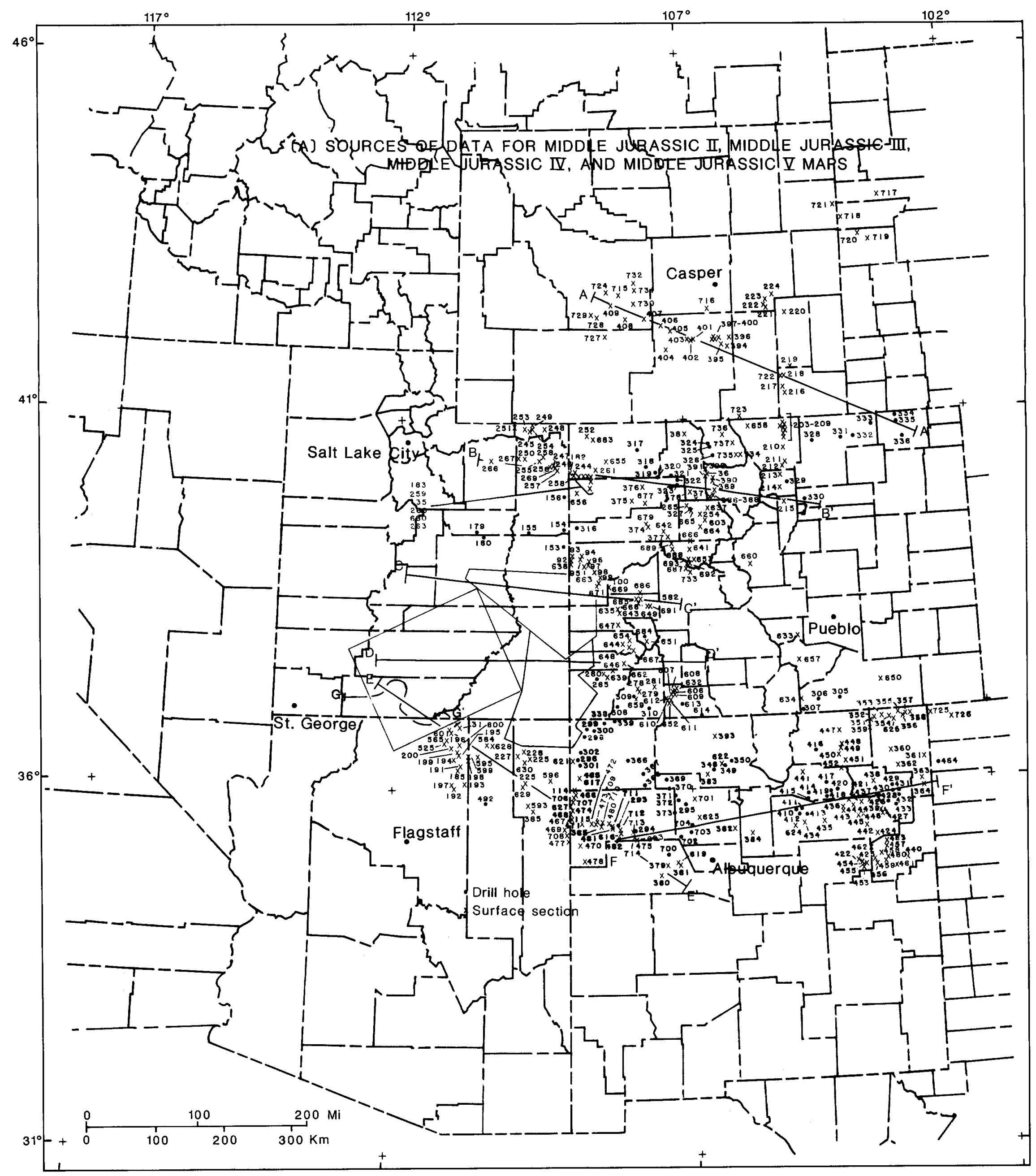

Fig. 24A. Data points for Middle Jurassic II, III, IV and V maps also showing lines of cross section. See Table 7 for location names and references. 
(B) SOURCES OF DATA FOR MIDDLE JURASSIC II, MIDDLE JURASSIC III,

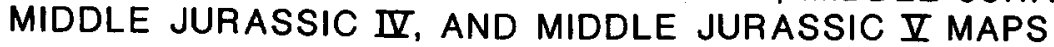

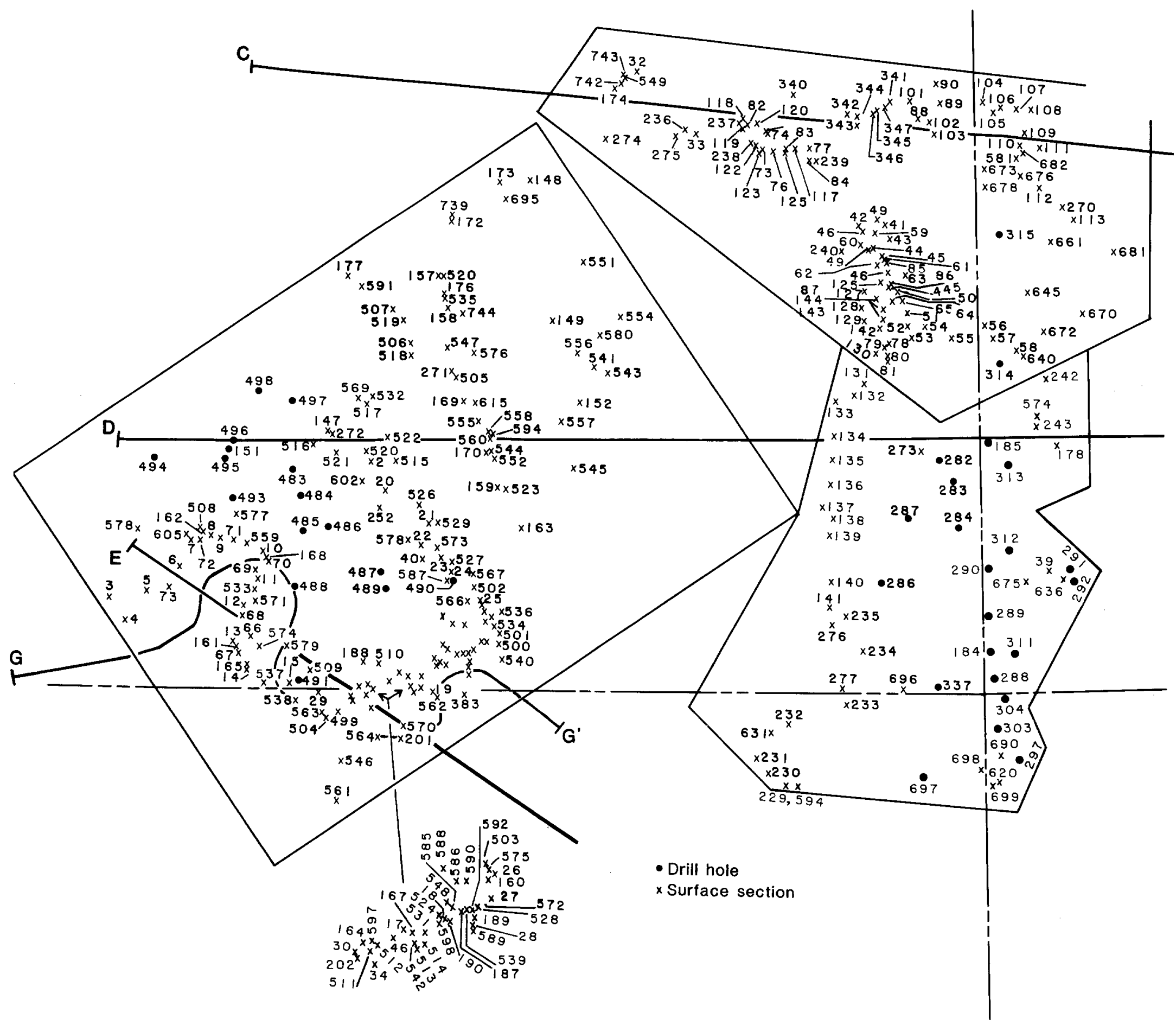

Fig. 24B. As Fig. 24A but enlarged to show detail in areas of tight control. See Table 7 for location names and references. 


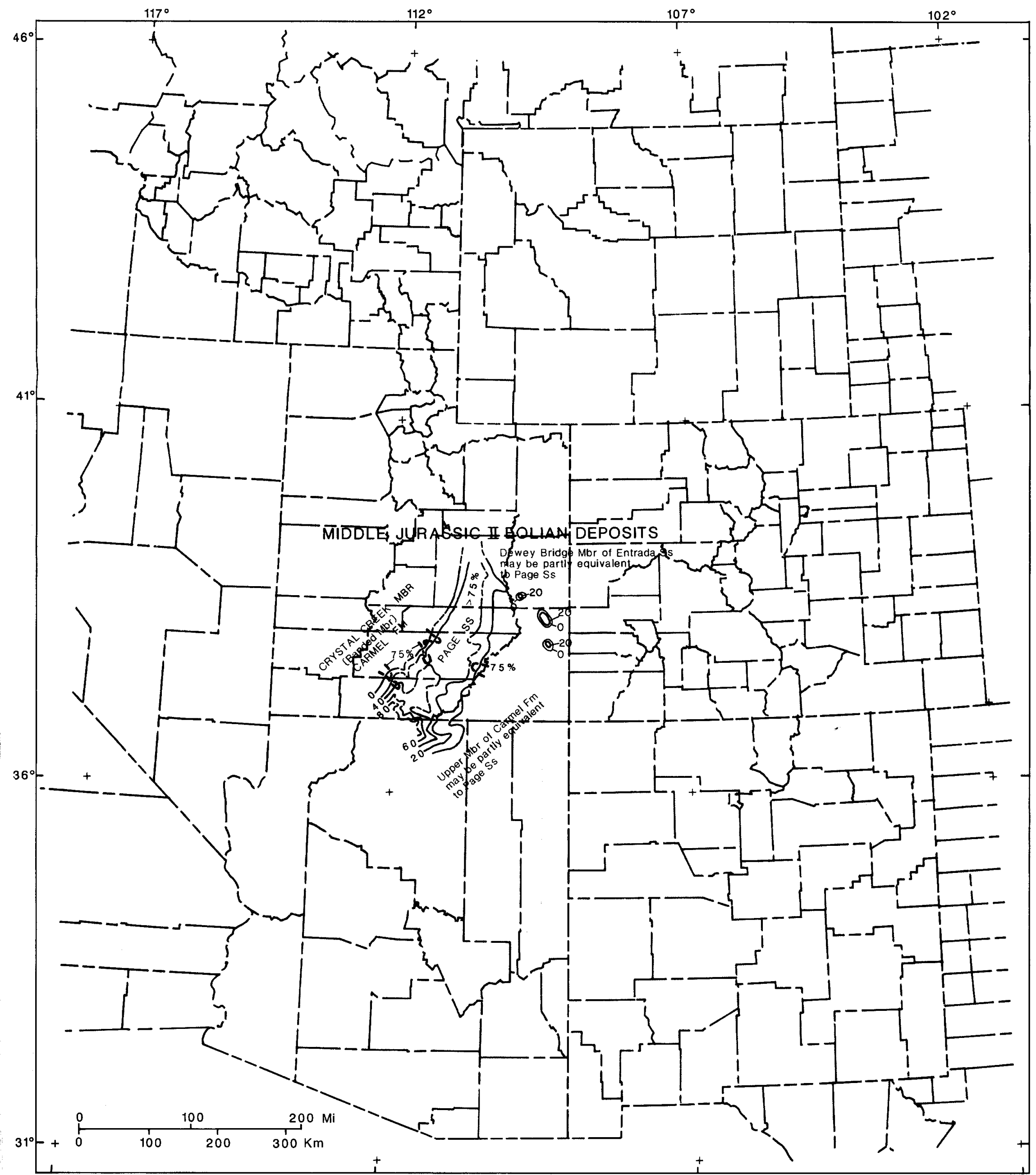

Fig. 25. Geometry and facies relations of Middle Jurassic II eolian deposits. Heavy lines show approximate percentage of eolian sandstone. Isopach interval $20 \mathrm{~m}$. Solid lines where outcrops occur; dashed lines where interval in subsurface or removed by erosion. 



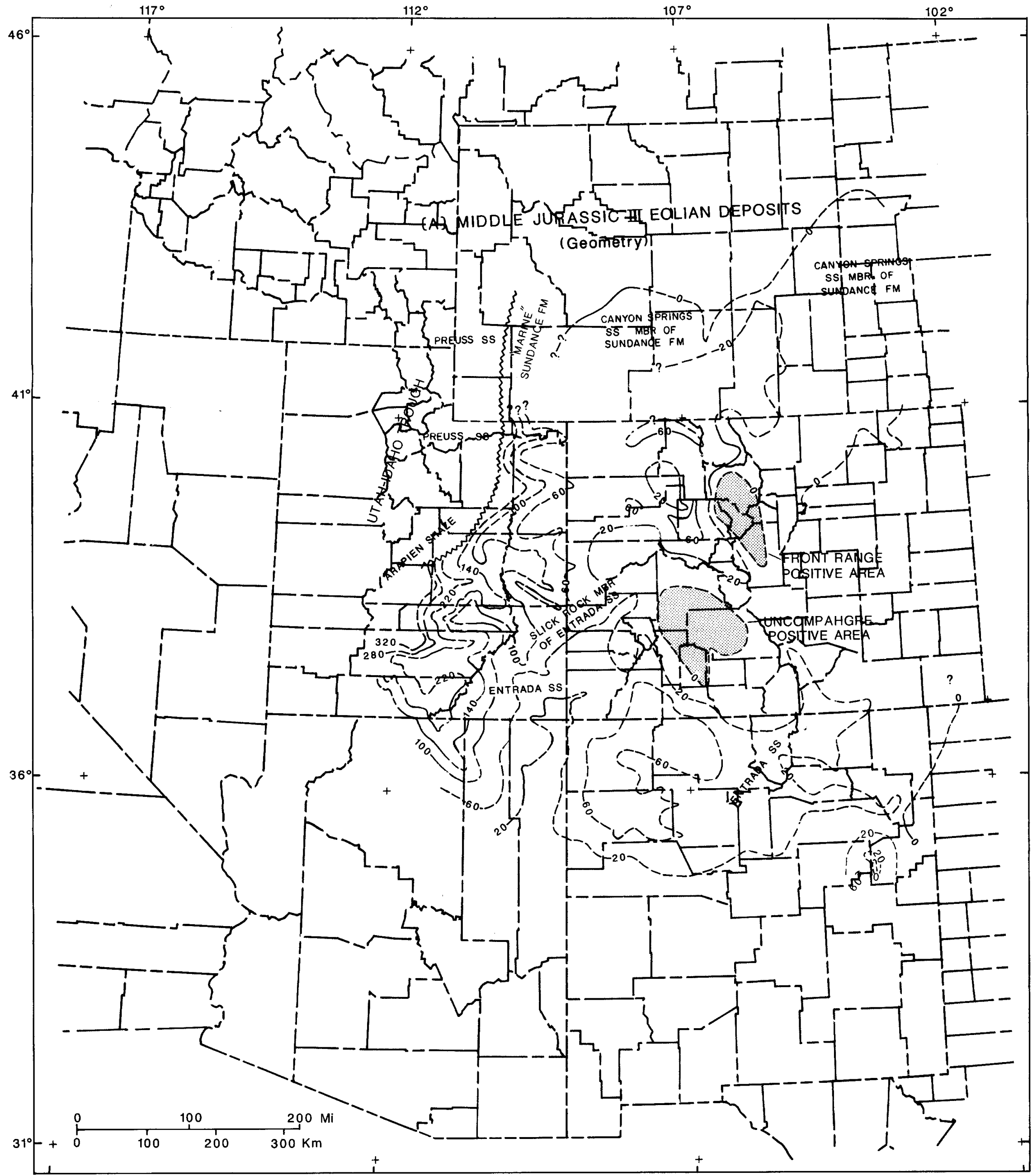

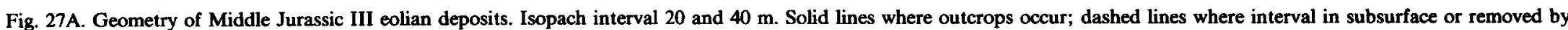
erosion. 


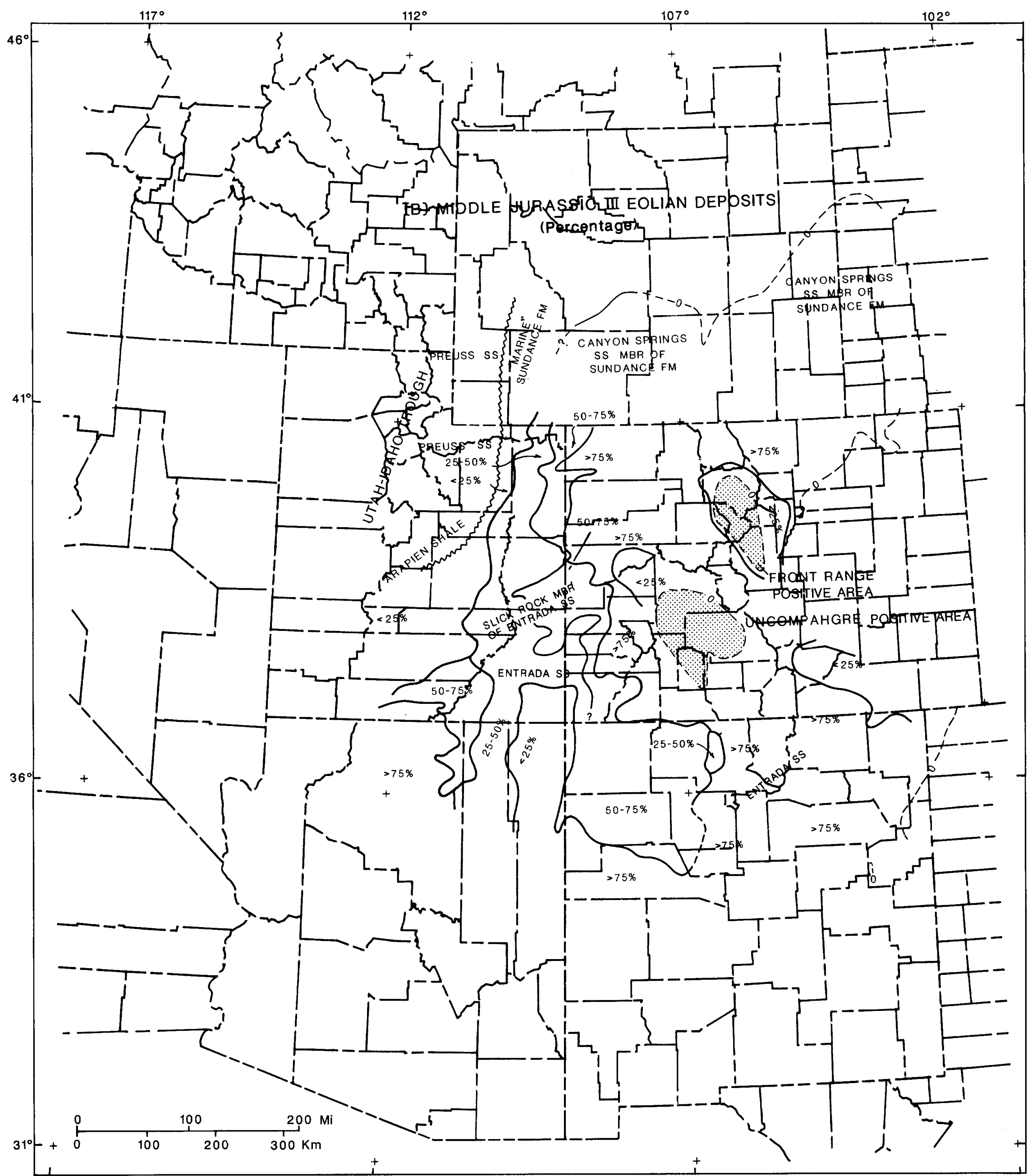

Fig. 27B. Facies relations of Middle Jurassic III eolian deposits. Isopach interval 20 and $40 \mathrm{~m}$. Solid lines where outcrops occur; dashed lines where interval in subsurface or removed by erosion. 


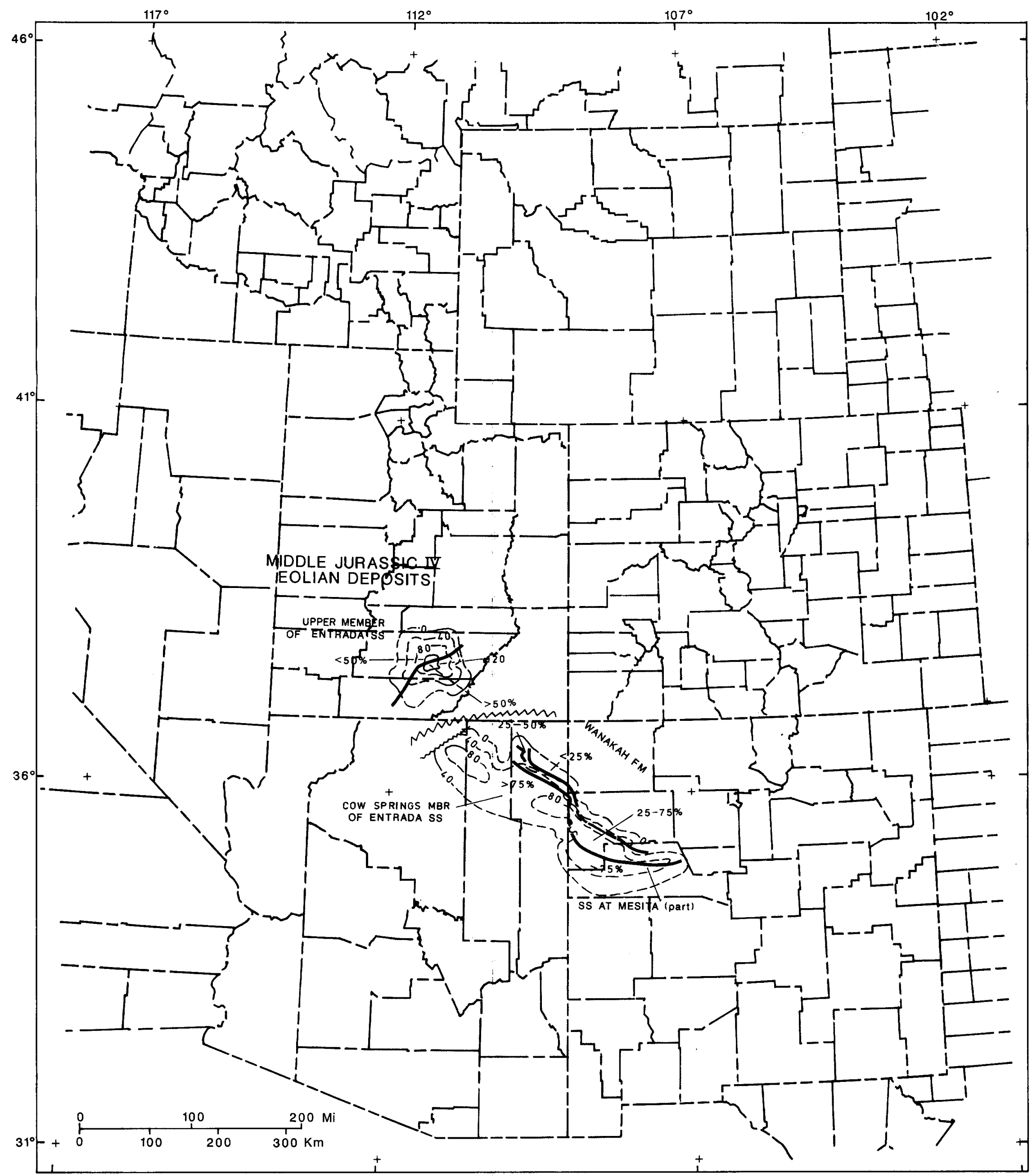

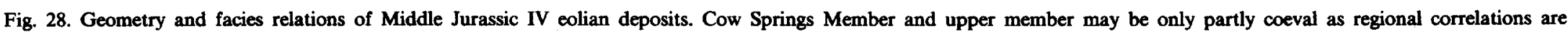
uncertain. Isopach interval $40 \mathrm{~m}$. Solid lines where outcrops occur; dashed lines where interval in subsurface or removed by erosion. 

quartzose composition of the rock. The quartzite of McGery Canyon in the Paradise Range (sect. 33, T12N, R37E, Nye County, Nevada), currently being mapped by N.J. Silberling of the U.S. Geological Survey, consists of similar lithologies and has similarly poor but suggestive evidence of an eolian origin. The thickness of these units is unknown but each is at least $100 \mathrm{~m}$ thick and the quartzite of McGery Canyon may be considerably thicker.

Isolated outcrops of clean quartz sandstone and quartzite near Currie in northeastern Nevada that are interpreted by some workers as a marine facies of the Aztec Sandstone have added more confusion than resolution to interpretations of late Early Jurassic eolianites. The beds are flat laminated or contain scarce thin tabular-planar crossbed sets (most of which are less than $15 \mathrm{~cm}$ thick) that do not appear to be eolian in origin. Orange quartz sandstone beds less than $2 \mathrm{~km}$ south of Currie may well correlate with the Aztec but they are largely flat laminated and do not represent dune deposits. They could have been deposited on eolian flats adjacent to the main body of an erg or they may have been deposited in subaqueous environments. Red quartz sandstones or quartzites about $10 \mathrm{~km}$ north and northwest of Currie are almost entirely flat laminated and may have been deposited in environments similar to the beds just south of Currie. These beds are better cemented (with silica) and a different color (red rather than orange) than the beds south of Currie. The stratal relationships of these beds are questionable and it is conceivable that they might be Paleozoic in age. In summary, none of the beds around Currie appear to have been deposited in eolian dune fields and for that reason they were not included in this study.

Stratigraphic relationships at the base of the isopach interval are poorly understood in northwestern Colorado and northeastern Utah. Poole and Stewart (1964) suggested that much of the Glen Canyon Sandstone in this area may be equivalent to the Lukachukai Member of the Wingate Sandstone and Kayenta Formation farther southwest in southeastern Utah and southwestern Colorado. On the other hand, we feel that the regional stratigraphic relationships (for exam- ple, see Pipiringos and O'Sullivan, 1978, pl. 1, section B-B' between $\mathrm{U} 12$ and W59-W60) point toward a correlation in which only the lower 15-30 $m$ of flat-bedded strata in the Glen Canyon Sandstone correlate with the Lukachukai Member and Kayenta Formation. If correct, this yields a correlation of the upper or predominantly eolian part of the Glen Canyon Sandstone with the Navajo and Aztec Sandstones and with the eolian upper part of the Nugget Sandstone. We recognize interfingering at the base of eolian strata that comprise the upper Nugget, upper Glen Canyon, Navajo and Aztec Sandstones. However, we do not feel that the interfingering is of sufficient magnitude to make the upper Glen Canyon equivalent to the Lukachukai Member of the Wingate Sandstone or to any significant part of the Kayenta Formation, nor do we think that the upper Glen Canyon correlates with any appreciable part of the lower or Bell Springs Member of the Nugget Sandstone. The isopach interval on Fig. 18 reflects these correlations.

The late Early Jurassic erg deposits attain a maximum thickness of $677 \mathrm{~m}$ in the central Utah part of the Utah-Idaho trough; they thin and pinch out eastward owing to eastward beveling beneath the J-2 unconformity (Fig. 19). The original eastward extent of the erg is unknown, but to our knowledge there are no sedimentologic hints that the sandstone grades eastward into a noneolian facies a short distance east of the outcrop limits of these beds. Thus, the erg could well have extended some considerable distance farther east than its present extent suggests. The erg deposits tend to thicken westward into the Utah-Idaho trough and, in southeastern Idaho and southeastern California, they appear to thin west of the trough. However, the data are unreliable in these areas and one cannot be assured that the westward thinning is real and not a reflection of scarcity of measurements and poor quality of the data (owing to cover, estimated thicknesses rather than measurements, and to structural or stratigraphic complexities). Most time-stratigraphic units of late Paleozoic and Mesozoic age in the Western Interior thin eastward onto the craton by depositional processes. Judging from this, it would seem as though the late Early Jurassic erg units 

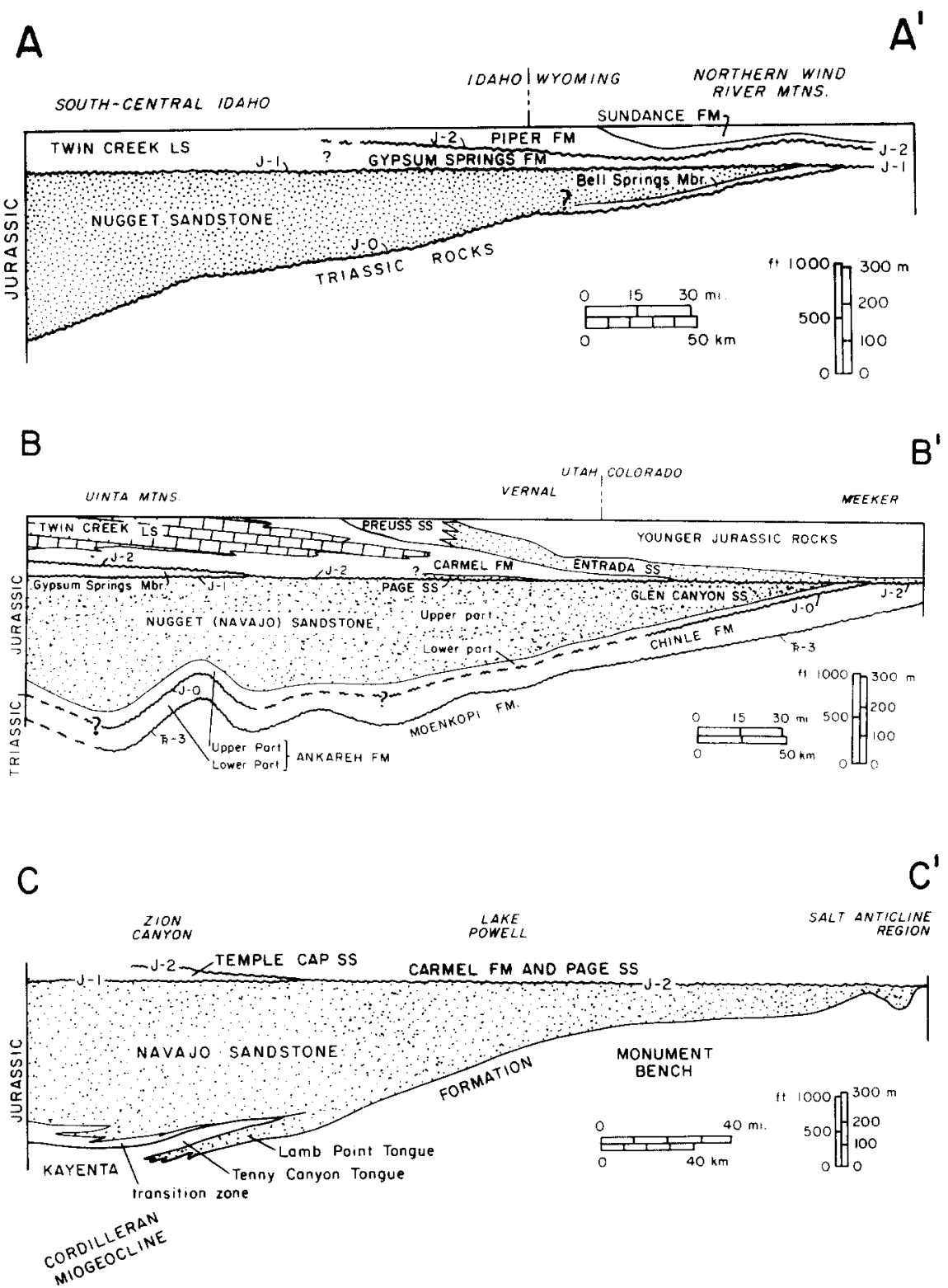

Fig. 19. Restored cross-sections showing eolian deposits in Lower Jurassic II rocks. Locations shown on Fig. 17.

also thinned eastward depositionally, but lack of stratigraphic markers within these deposits makes this difficult to confirm.

The role of intertonguing of the crossbedded eolian beds with other strata must be understood when evaluating thickness variations in the late Early Jurassic. Hypothesized intertonguing of the Navajo Sandstone with the Middle Jurassic Carmel Formation reported by earlier workers (Wright and Dickey, 1963) is now known to involve another formation (the Page Sandstone) rather than the
Navajo. Accordingly, the Aztec, Navajo, Glen Canyon and Nugget Sandstones are now thought to be unconformably overlain everywhere by Middle Jurassic or younger strata (Peterson and Pipiringos, 1979). On the other hand, intertonguing at the base of the Aztec and Navajo Sandstones has been documented by several workers (Harshbarger et al., 1957; Averitt, 1962; Wilson, 1965; Middleton and Blakey, 1983). How much lateral replacement of the uppermost or eolian part of the Nugget Sandstone by underlying strata 
of the Bell Springs Member of the Nugget (Pipiringos, 1968; Doelger and Steidtmann, 1985) has not, to our knowledge, been determined but it is not considered to be appreciable.

The direction of lateral replacement of Navajo or Aztec tongues by units in the underlying Kayenta Formation is only documented in a few areas, but where it has been determined it is consistent with paleowind patterns determined from crossbedding dip vector studies. Harshbarger et al. (1957, p. 22, pl. 2) report southeastward gradation of Navajo tongues into the Kayenta Formation in northeastern Arizona, which is parallel to the southeastward direction of eolian transport in this area during Early Jurassic time (Peterson, this volume). It is highly likely that the Lamb Point and Shurtz Sandstone Tongues of the Navajo in southwestern Utah (Averitt, 1962; Wilson, 1965) are different names in different areas for the same tongue of the Navajo. If this correlation is correct, the tongue thins southwestward in the same direction (Fig. 19) that the winds moved in this area (Peterson, this volume).

During Early Jurassic time an Andean-type magmatic arc extended northwestward from southern Arizona into California (Bilodeau and Keith, 1986). Eolian strata included in the isopach interval (Fig. 18) lap southward onto older rocks in this area, apparently because the erg migrated into highlands produced by uplift in the arc. Interfingering or interbedding of the eolian sand with arc volcanics was documented by Marzolf (1983a) and Bilodeau and Keith (1986). In this area, the upper boundary of the Lower Jurassic Series (and thus of the isopach interval) is difficult to determine owing to the difficulty of distinguishing Middle Jurassic volcanics that postdate strata of the isopach interval from Early Jurassic volcanics that were coeval with the eolian beds. Clearly, a study of the isotopic dates of the volcanics in this area is sorely needed.

In summary, the isopach interval thins eastward owing primarily to truncation beneath the J-2 unconformity, and probably to some as yet undetermined amount of depositional thinning. The lower contact of the isopach interval is diachronous, becoming younger generally toward the south owing to interfingering with and lateral replacement by non-eolian units in the Kayenta Formation and probably with non-eolian strata in the lower part of the Nugget and Glen Canyon Sandstones. In southern Arizona and California, the eolian unit appears to thin southward by onlap where it rests on the landward side of the Early Jurassic Andean-type magmatic arc. Intertonguing and southward regional replacement of the lower part of the Aztec and Navajo Sandstones by noneolian units should be reflected in southward thinning of the isopach interval, but this is not apparent from the isopach map (Fig. 18). Although there may be several explanations for this, the simplest and most appealing is that the intertonguing does not involve an appreciable thickness of beds (100 $\mathrm{m}$ or less in most locations). Also, the zone of intertonguing is at or near the southern margin of Jurassic outcrops on the Colorado Plateau so trends to the south are uncertain.

Several positive and negative structural elements (Fig. 20) are reflected by the configuration of the isopach lines. In northeastern Utah and adjacent areas, a trough is reflected as a westsouthwest-trending area of thick Nugget and Glen Canyon Sandstones that coincides roughly with the present-day Uinta Mountains structural element. The Uinta Mountains element is known to have been active, either as a positive or negative structural feature, since Precambrian time (Bryant, 1985; Hansen, 1986) and movement in the Jurassic is therefore not unexpected. A parallel trend of thick Nugget Sandstone just northwest of the Uinta trough may reflect a separate trough or, by reconfiguring the isopach lines around the thin area between the two thick areas, both thick areas combined may reflect a somewhat complicated but considerably larger Uinta trough. Another thick trough-like area is suggested by the configuration of the isopach lines in southern Arizona but stratigraphic complexities and uncertainties as well as incomplete sections make such an interpretation speculative.

A broad structural bench or terrace identified as the Monument bench (Fig. 20) is identifiable in southeastern Utah in the vicinity of the present-day Monument upwarp. Isopach and facies studies in this area indicate that this feature was tectonically active, either as a structural bench or uplift, all 
during the Jurassic Period (Peterson, 1986). A reentrant in west-central Colorado and adjacent parts of Utah reflects the ancestral Uncompahgre uplift, an important structure that was repeatedly activated in late Paleozoic, Mesozoic and Cenozoic time. A similar reentrant in central Arizona may reflect positive movement of the Mogollon uplift, but lack of data over a broad area makes the configuration of this feature somewhat speculative.

Differential movement on salt-cored anticlines in west-central Colorado is reflected in the irregular configuration of the isopach interval east of the Monument bench. The salt was deposited during Pennsylvanian time but it moved from the Late Pennsylvanian to at least the end of the Jurassic to produce several salt-cored anticlines (Cater, 1970). The anomalously thin area within the Utah-Idaho trough in west-central Utah is in an area of considerable structural complexity and may not be real.

Available data are too sparse to determine the percent of cross-bedded sandstone in the isopach interval. Visual observations aided by a few measurements indicate that the isopach interval consists of more than $70 \%$ cross-bedded sandstone in most places in the Western Interior. However, the eolian sandstone is interbedded with volcanics and (or) non-eolian, flat-bedded siltstone and sandstone in southern Arizona and California where the percentages are considerably lower. Additional complications in this area are that the isopach interval is incomplete due to erosion or faulting, or reliable criteria to distinguish Middle Jurassic from Lower Jurassic beds have not been found.

The precise timing of movement on the abovementioned structures remains somewhat conjectural because of a lack of detailed facies studies that might yield an indication of movement during deposition. Judging from the isopach map alone, one can only speculate that the movement was during and (or) immediately after deposition of the isopach interval. However, judging from the record of movement on many of these structures throughout much of the Phanerozoic, it would seem more likely that the structures moved continuously during deposition as well as during the succeeding erosion interval.

\section{Middle Jurassic eolian deposits}

\section{Introduction}

The base of the Middle Jurassic is either the J-1 or J-2 unconformity (Pipiringos and O'Sullivan, 1978). The unconformity is overlain by a variety of deposits of continental and marine origin. Within rocks of Middle Jurassic age we recognize the following eolian-bearing units: Temple Cap Sandstone, Page Sandstone, Entrada Sandstone and Romana Sandstone (Fig. 2).

\section{Middle Jurassic I eolian deposits}

The Temple Cap Sandstone of early Middle Jurassic age (early part of the Bajocian Age according to Imlay, 1980) is the oldest formation in the Middle Jurassic San Rafael Group and is only present in the southwestern part of the Colorado Plateau in southwestern Utah (Fig. 2). Based on its stratigraphic position between the $\mathrm{J}-1$ and J-2 unconformities, the formation correlates with the Gypsum Springs Member of the Twin Creek Limestone in northern Utah, which occupies a similar stratigraphic position. Information used to construct the isopach map is given in Table 6 and the geographic distribution of data points is shown on Fig. 21. Eolian beds in the formation are of limited extent but may have once been more extensive (Chan and Kocurek, this volume).

The Temple Cap consists of two members on the Colorado Plateau but only the upper member is eolian. The upper or White Throne Member consists of crossbedded sandstone deposited in eolian environments. The underlying Sinawava Member consists of flat-bedded silty sandstone and scarce mudstone deposited in sabkha and possibly hypersaline marine environments. At the west edge of the Colorado Plateau, the White Throne grades into red beds that are included in the Sinawava Member but, in addition to the lithologies noted above, the westernmost Sinawava includes thin beds of limestone and gypsum (Peterson and Pipiringos, 1979).

Temple Cap strata contain the record of crustal movements coincident with deposition. The formation is wedge-shaped and thickens irregularly 
A $A^{\prime}$

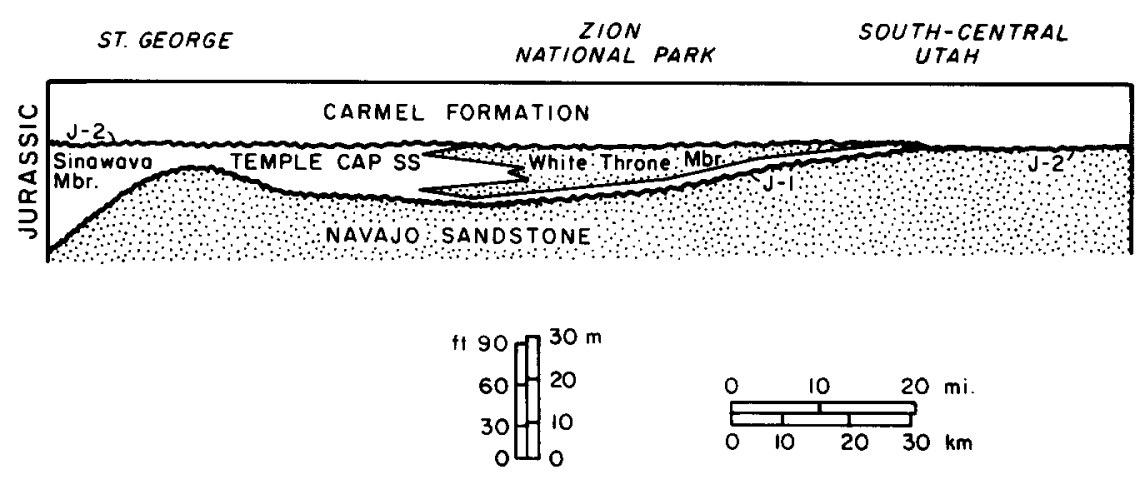

Fig. 23. Restored cross-section of Temple Cap Sandstone. Location shown on Fig. 21.

southwestward and westward toward the Utah-Idaho trough (Fig. 22), supporting the contention that the trough continued as an active downwarp from Early Jurassic time (Fig. 20). The westward facies change from eolian sandstone of the White Throne Member to red beds of the Sinawava occurs rather abruptly at the Hurricane fault, suggesting that the eastern boundary of the trough, at least in southwestern Utah, was the ancestral Hurricane fault. Movement would have been with the west side down, which is the same as that which is presently displayed there. The formation thins eastward toward the west side of the Kaibab uplift, suggesting that this structural element also was active during and (or) immediately following deposition. Although the formation has an erosion surface at the top (the $\mathrm{J}-2$ unconformity), the Sinawava Member is overlain depositionally by the overlying White Throne Member and thins eastward by onlap toward the Kaibab uplift (Fig. 23). This, then, is an indication that the Kaibab uplift was elevated immediately before and (or) during deposition as well as immediately after deposition. It is difficult to interpret the structural history in the northeastern part of the area underlain by the Temple Cap owing to the lack of drill hole information.

Interpretations gleaned from the percentages of eolian sandstone can be misleading in some cases and should be done with consideration of the stratigraphy of the formation. The percent eolian sandstone drops abruptly at the Hurricane fault, as might be expected because it coincides with the abrupt facies change of the White Throne Member into the Sinawava. A southward lowering in the percent of eolian sandstone is an indication that the dune facies probably did not extend very far south into Arizona. Lower values in eolian sandstone percentages at the east end of the Temple Cap outcrop belt, however, reflect abrupt truncation of eolian beds in the White Throne Member beneath the J-2 unconformity and are not necessarily an indication that the eolian facies did not extend farther east.

\section{Eolian deposits in the Carmel Formation}

Scattered eolian deposits are present in the Carmel Formation across southern Utah and north-central Arizona. Many of these deposits are undocumented or casually mentioned in the literature. We are unable to isopach or accurately map most of these deposits, but merely offer the following brief discussion:

(1) Eolian deposits, both of dune and sandsheet origin, occur in the upper member in southcentral Utah. Similar deposits at approximately the same horizon occur at scattered locations along the Utah-Arizona state line eastward to near Page, Arizona.

(2) Eolian dune deposits occur in isolated, preserved dune forms in the upper part of the undivided Carmel Formation along the Green River northwest of Moab, Utah.

(3) In north-central Arizona, the Carmel Formation is a poorly exposed sandy unit informally 
called the "Reservation facies". At several localities where fair exposures are present, thin eolian deposits are present including both small dune and sand-sheet deposits.

(4) In the southern Four Corners region east of Monument Valley, a light-colored sandstone in the Carmel Formation (undivided) may be of eolian origin.

\section{Middle Jurassic II eolian deposits}

The Middle Jurassic (Bajocian-Bathonian) Page Sandstone (Fig. 2) consists of a north-northeastward-trending sandstone body in south-central Utah and north-central Arizona (Figs. 24 and 25). Previous to Peterson and Pipiringos (1979), the Page had been included in the underlying Navajo Sandstone, but recognition of the regional J-2 unconformity of Pipiringos and O'Sullivan (1978) formed the basis for distinguishing it as a separate formation.

In southern Utah, the Page consists of a lower unit, the Harris Wash Tongue, and an upper unit, the Thousand Pockets Tongue, separated by the Judd Hollow Tongue of the Carmel Formation (Fig. 26). Northward the Page Sandstone is undifferentiated, but this probably is the more extensive Harris Wash Tongue, as the Thousand Pockets Tongue apparently pinches out northward in the northwestern part of the Henry basin. As seen in Fig. 26, the Harris Wash Tongue decreases in thickness southward and the Thousand Pockets Tongue increases. The Judd Hollow Tongue thins eastward and pinches out in the undivided Page a few kilometers east of Page, Arizona. For the

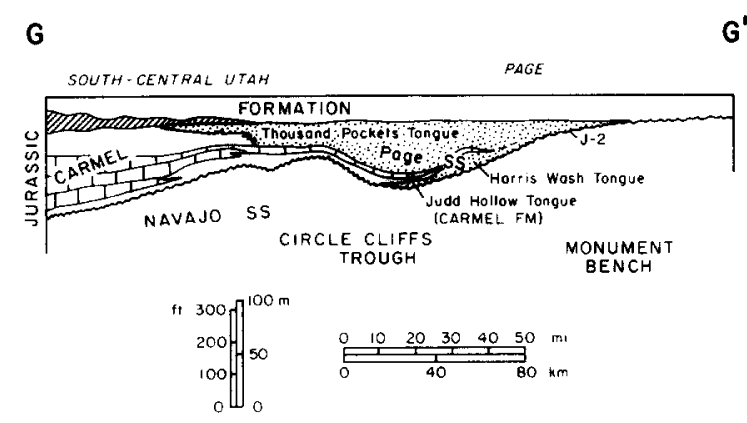

Fig. 26. Restored cross-sections of Middle Jurassic II eolian deposits in the Page Sandstone. Locations shown on Fig. 24. purpose of the isopach map (Fig. 25), thicknesses of the Judd Hollow Tongue of the Carmel Formation were omitted so that the entire Harris Wash-Judd Hollow-Thousand Pockets interval is thicker than shown. Table 7 lists the data base for the Page Sandstone.

To the west and northwest the entire Page Sandstone interfingers with and is laterally replaced by the Carmel Formation consisting of red mudstones, limestones, and gypsiferous deposits. Thus, the Harris Wash Tongue grades into the Judd Hollow Tongue (Limestone Member of the Carmel Formation in southwestern Utah). The Thousand Pockets Tongue is replaced westward by the Crystal Creek (Banded) Member of the Carmel Formation. Eastward, the Page Sandstone thins by onlap against the ancestral Monument bench and it may also thin eastward by intertonguing with red beds of the Carmel Formation (Peterson, 1986). To the east the Page is a timeequivalent of the lowermost part of the upper member of the Carmel Formation and possibly to the lowermost red beds of the Dewey Bridge Member of the Entrada Sandstone. The Page Sandstone is overlain by the upper member of the Carmel Formation (Fig. 26), or by the Dewey Bridge Member of the Entrada.

The thickest deposits of the Page are in a southern extension of the Circle Cliffs trough of north-central Arizona (Figs. 20 and 25), adjacent to where it has largely been removed by erosion. The sandstone thins northwestward and southeastward from the axis of the sandstone body. The northern extent of the Page Sandstone is not yet known; Pipiringos and O'Sullivan (1976) show it extending northward into southwestern Wyoming. Outliers of sandstones deposited in depressions on the J-2 surface east of the main body of Page Sandstone have been assigned to the Page by O'Sullivan and Pierce (1983). These may be coincident with structure associated with salt tectonics. Earlier, these same deposits had been included in the Entrada Sandstone (O'Sullivan, 1980a).

The Page Sandstone consists predominantly of cross-stratified eolian sandstone except along its western margins where the percentages of crossstratified sandstone decrease in tongue-like projections. However, outliers of Page Sandstone and 
Page Sandstone-filled depressions up to $10 \mathrm{~m}$ thick on the J-2 surface are composed of coarser-grained, flat to low-inclined cross-strata of wind-ripple origin (Knight, 1986). Western outcrops of Page Sandstone commonly are deformed, probably the result of evaporite dissolution in the underlying Carmel Formation.

The Page Sandstone is interpreted as a coastal erg system that paralleled the Carmel sabkha and shallow marine embayment to the west; the eastern inland limits were largely defined by the Monument bench (Fig. 20) (Peterson and Pipiringos, 1979; Caputo, 1980; Blakey et al., 1983; Knight, 1986; Peterson, 1986; Kocurek and Hunter, 1986). Eastward of the Page Sandstone, potentially equivalent units (lower Dewey Bridge Member of the Entrada Sandstone, lower part of the Upper Member of the Carmel Formation) are largely sabkha in origin. The Page Sandstone was deposited over the irregular, eroded J-2 surface that is commonly marked by thin-granule lag deposits and polygonal fractures (Peterson and Pipiringos, 1979), the latter interpreted by Kocurek and Hunter (1986) as forming in an evaporite-encrusted surface. Knight (1986) has interpreted the coarser-grained basal deposits of the Page Sandstone that fill depressions on the J-2 surface as probably predating the Page erg system per se, and representing sand deposit over the J-2 surface in an overall sand-undersaturated environment in which deposition occurred only in depressions.

\section{Middle Jurassic III, IV, V eolian deposits}

\section{Introduction}

The Middle Jurassic (Bathonian-Callovian) Entrada Sandstone system and directly equivalent units (Fig. 2) form perhaps the most complex eolian system in the western United States, and are present in nine states extending from Utah to the Texas and Oklahoma panhandles, and from Arizona and New Mexico to the Black Hills of South Dakota. This erg system, composed of numerous units, is illustrated here as three units on three maps. Our three units do not necessarily coincide with previous subdivisions of the Entrada as explained below. Because of stratigraphic complexities and uncertainties and despite our at- tempts to not do so, part of the three intervals possibly overlap in time and all are likely strongly diachronous.

Figure 27 shows the most extensive and oldest parts of the Entrada system consisting of: lower and middle members of the Entrada Sandstone in west-central Utah; Entrada Sandstone of southern Utah, northern Arizona, southwestern and southeastern Colorado, and northern Utah; Slick Rock Member of the Entrada Sandstone in east-central Utah and west-central Colorado; Canyon Springs Member of the Sundance Formation in Wyoming, South Dakota, and northwestern Colorado; Iyanbito, medial silty and upper sandy members of the Entrada Sandstone in northwestern New Mexico; and Entrada Sandstone and Exeter Member of the Entrada Sandstone in east-central and eastern New Mexico, Texas, and Oklahoma. The Dewey Bridge Member of the Entrada Sandstone in east-central Utah is not included on Fig. 27 because this unit generally lacks eolian deposits and because it correlates with the older Carmel Formation (see Page Sandstone discussion).

Figure 28 shows the Upper Member of the Entrada Sandstone of west-central Utah, the possibly somewhat older Cow Springs Member of the Entrada Sandstone in northeastern Arizona and the Cow Springs Member and overlying lower part of the sandstone at Mesita in New Mexico. It should be noted that the Exeter Member of the Entrada Sandstone (included in Fig. 27) in northeastern New Mexico may be time-equivalent to the Cow Springs member (Lucas et al., 1985). Restored cross-sections are shown on Fig. 29 and Table 7 lists Entrada Sandstone data points. Figure 30 shows what may be the youngest part of the Entrada erg systems, the Moab Tongue of the Entrada Sandstone in east-central Utah.

\section{Middle Jurassic III}

Overall, the Entrada Sandstone conformably overlies the Carmel Formation. Progressing eastward to the pinch-out of that unit, the Entrada Sandstone rests directly on the J-2 unconformity that is underlain by progressively older rocks to the east.

Across Wyoming the Canyon Springs Member of the Sundance Formation rests on the J-2 surface 
A

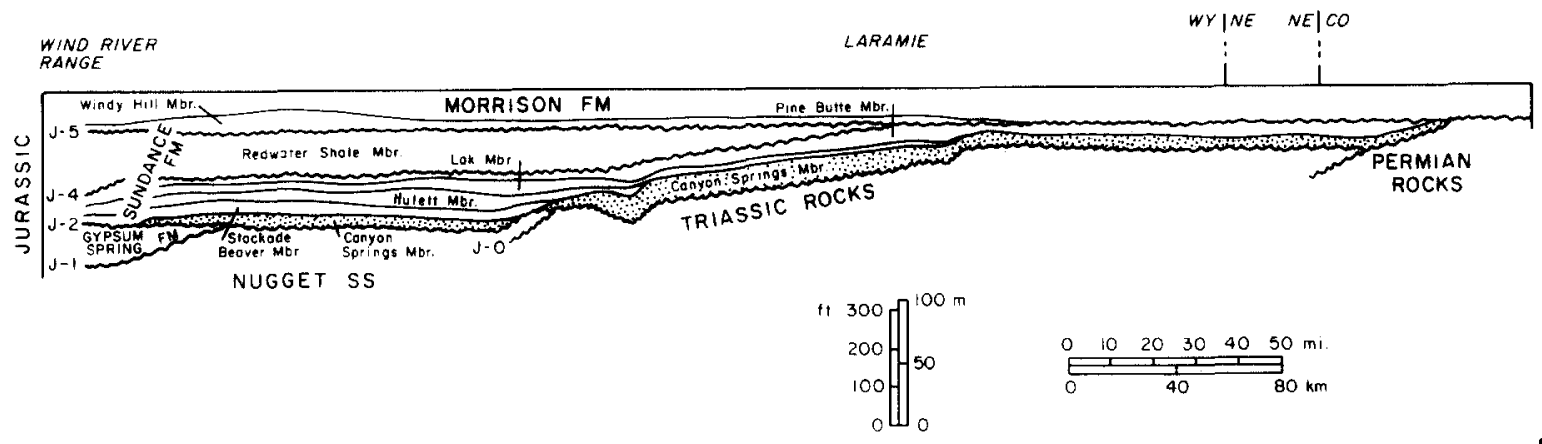

B

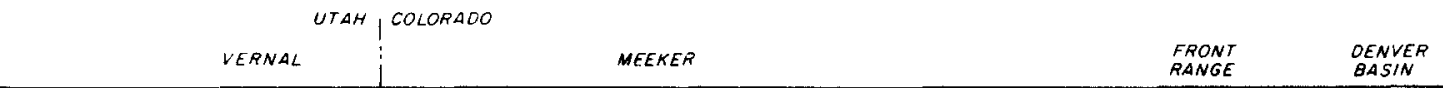

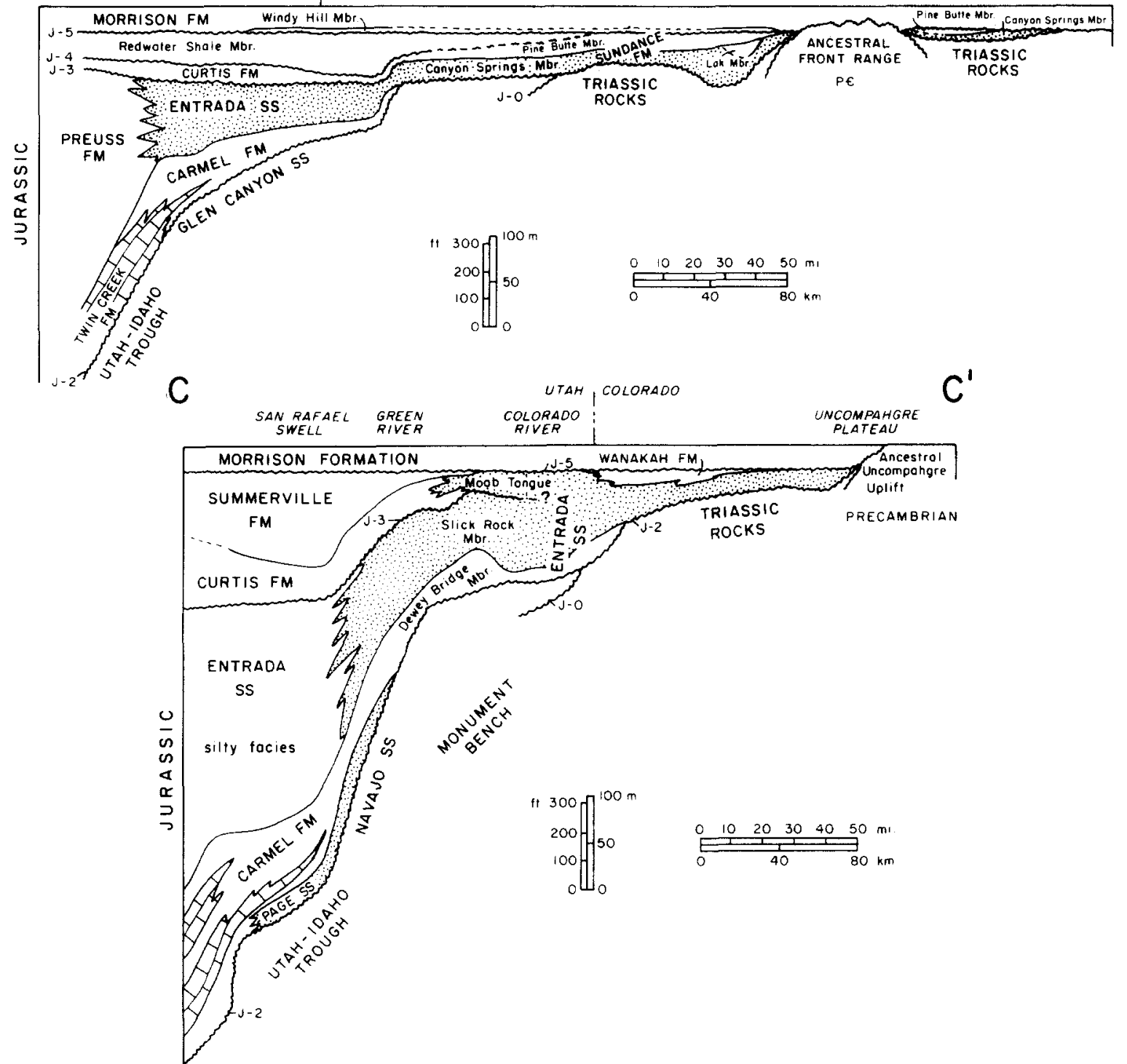

Fig. 29. Restored cross sections of Middle Jurassic II, III, IV and V eolian deposits in Page and Entrada Sandstones and Sundance Formation. Locations shown on Fig. 24. 
D

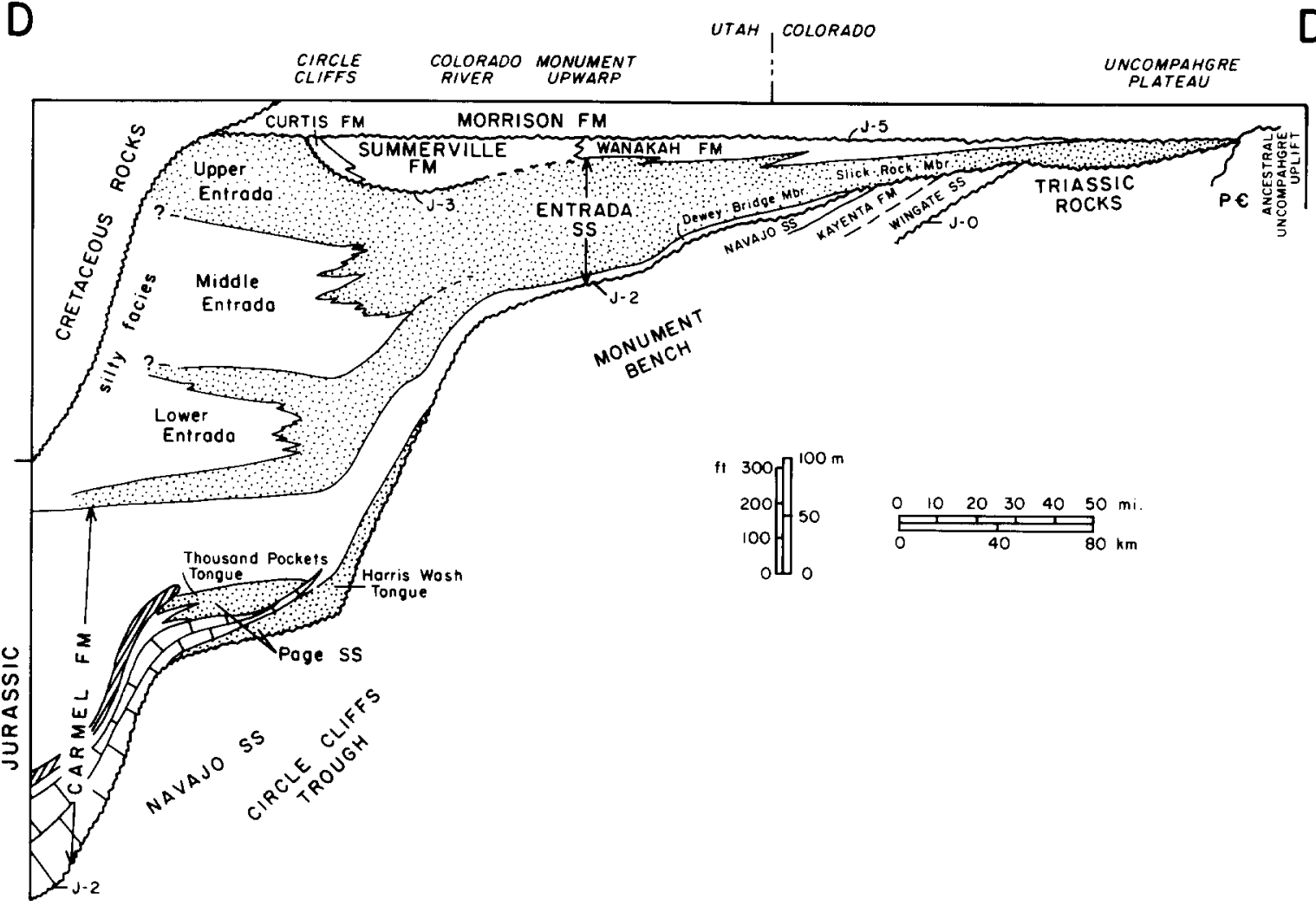

$E$

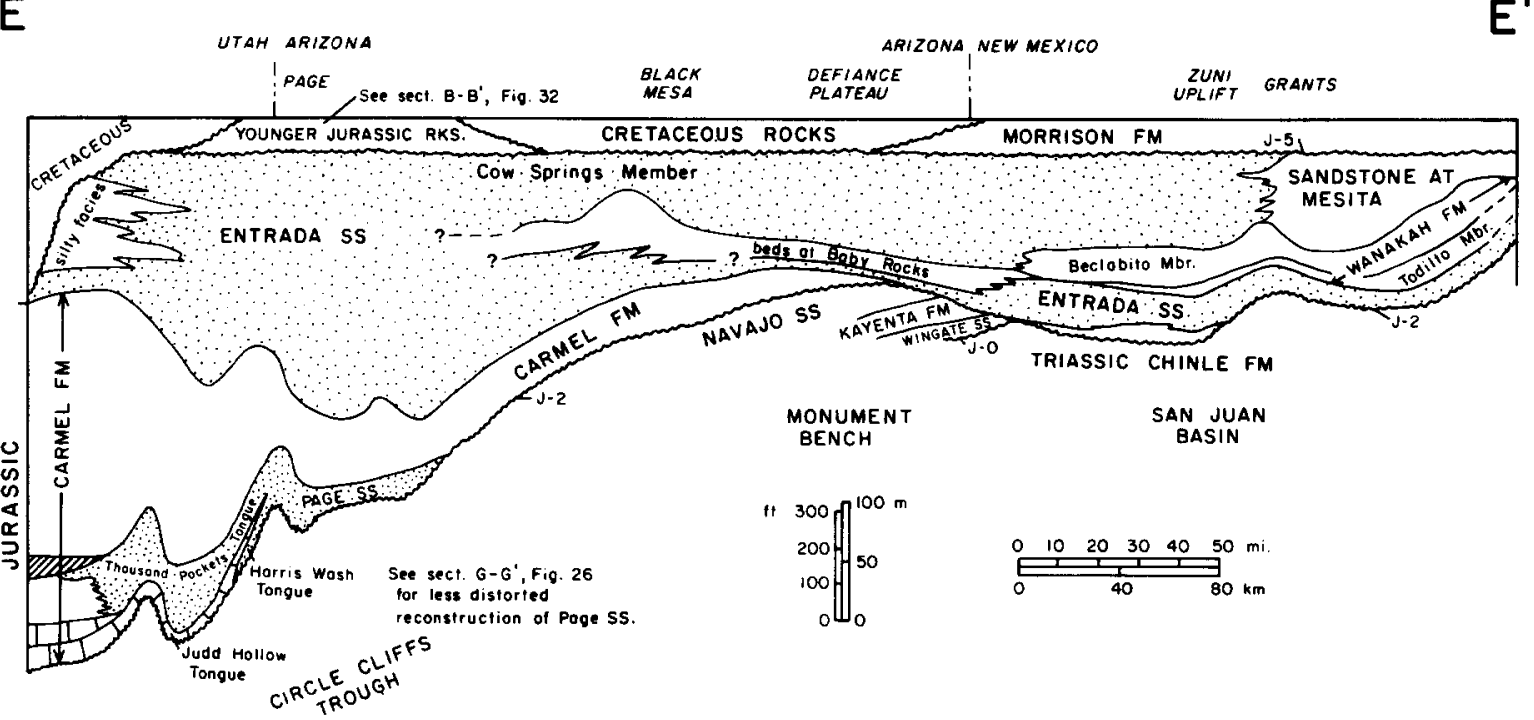

Fig. 29 (continued). See p. 58 for legend.

and pinches out northwestward and northward into marine strata of the Sundance Formation (Fig. 29). In northeastern Utah the Entrada Sandstone overlies the Carmel Formation and grades west into red beds of the Preuss Sandstone. Eastward across northwestern Colorado the Carmel Formation thins to zero and the Canyon Springs Member of the Sundance Formation directly over- 


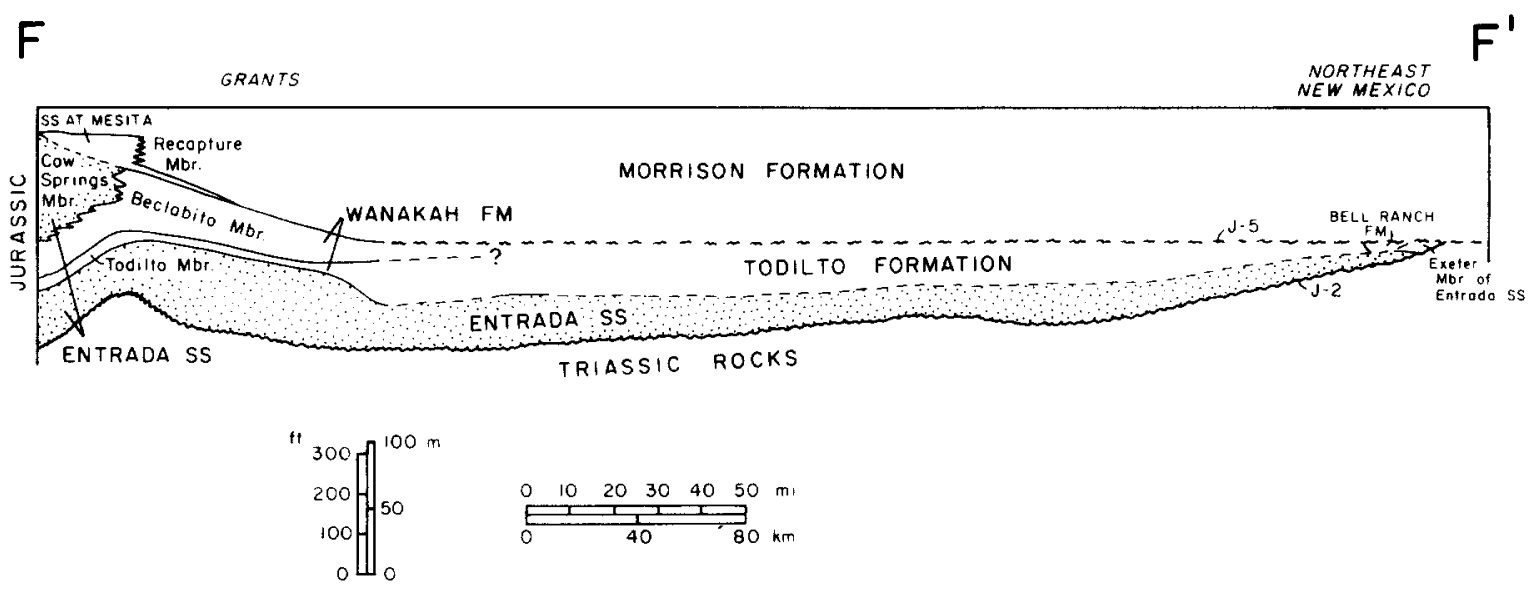

Fig. 29 (continued). See p. 58 for legend.

lies the J-2 surface; the Canyon Springs thins to pinch out by onlap against the ancestral Front Range, but is present again on the east side of the Front Range. A short distance farther east it pinches out again, presumably by onlap.

Correlations by Pipiringos and O'Sullivan (1978) and Imlay (1980) suggested that most of the Canyon Springs Sandstone Member of the Sundance Formation is slightly older than eolian deposits in the Entrada Sandstone to the southwest. The above workers suggested that the Entrada correlates with the Lak Member of the Sundance and that the underlying Canyon Springs Sandstone Member of the Sundance Formation correlates with the upper part of the Carmel Formation on the Colorado Plateau. The Canyon Springs becomes younger progressing southward across southern Wyoming and northern Colorado so that the southern part of the Canyon Springs replaces the Lak and therefore is a direct equivalent of the Entrada (Pipiringos and O'Sullivan, 1976). If correct, this documents the diachronous southward progradation of a major erg complex from the Central Rocky Mountains to the southern Colorado Plateau.

The Entrada Sandstone in central and southern Utah (Figs. 27 and 29C, D, E) grades westward into marine-sabkha deposits (Twist Gulch Member of the Arapien Shale), overlies the Carmel Formation or equivalent Dewey Bridge Member of the Entrada Sandstone, and lies on the J-2 surface in Colorado east of the eastward pinch-out of the Carmel-Dewey Bridge units. Similarly, but farther east, the Entrada Sandstone pinches out against the topographically and probably structurally highest part of the ancestral Uncompahgre uplift.

More complex relationships exist in Arizona and New Mexico where the Cow Springs Member is recognized within the upper part of the Entrada Sandstone (Fig. 29E, F) (see following section). Farther east in New Mexico, the Carmel Formation is absent and eolian deposits of the Entrada Sandstone overlie the $\mathrm{J}-2$ surface and Triassic rocks.

The main body of the Entrada system shown in Fig. 27 is generally overlain by marine or sabkha deposits across the western and northern Western Interior, but in southeastern Utah where the Moab Tongue occurs, in Arizona and New Mexico where the Cow Springs Member rests directly on the main body, and in west-central Utah where the upper member of the Entrada occurs, the unit is overlain by eolian deposits. In Wyoming and northwestern Colorado, the marine units are various members of the Sundance Formation (Figs. 2 and 29A, B). In northern Utah, equivalent marine rocks are the Curtis Member of the Stump Formation. Southward, marine, sabkha, or lacustrine units overlying the Entrada include the Curtis, Summerville and Wanakah Formations, the latter including the Todilto Limestone Member.

The isopach patterns (Fig. 27) illustrate the pronounced westward thickening of the Entrada 
erg system toward the Utah-Idaho trough, and an eastward thinning of the system across the craton to the irregular pinch-out along a north-south line in eastern Colorado. Superimposed on this overall trend, the isopach patterns reflect tectonic elements that were active at the time of deposition (Fig. 20).

Extending eastward at high angles to the trend of the Utah-Idaho trough are elongate troughs and basins. These include the Uinta Mountain trough, ancestral Uinta basin, an unnamed basin, the Circle Cliffs trough and the Black Mesa trough. Additional basins are evident eastward on the craton. These include the San Juan basin and a basin in east-central New Mexico.

Areas of relative uplift marked by thinning strata are also evident. Most evident are the elements of the Ancestral Rockies (Front Range and Uncompahgre positive areas) where isopach patterns show a thinning toward these elements. An unnamed high bisects the San Juan basin. The Defiance uplift, Monument bench, and an unnamed high in central Utah are evident from thinning of strata over them.

Facies patterns within the main body of the Entrada system are complex (Fig. 27). In general, there is a westward decrease in the percent of cross-stratified sandstone. Strata consisting of over $75 \%$ eolian cross-strata occur east of the Utah-Colorado border and east of the San Juan basin in southwestern Colorado and New Mexico. Similarly high percentages of cross-stratified sandstones occur near the outcrop limits in west-central New Mexico, southernmost central Utah and north-central Arizona. The general trend toward less eolian cross-strata westward is also disrupted by the presence of silty sandstone (beds at Baby Rocks) west of the Defiance uplift. Low percentages of eolian cross-strata occur in the southeastern part of the map area within the margins of the unit but near its pinch-out, and adjacent to elements of the Ancestral Rockies. Adjacent to the western portion of the eolian system are large quantities of mudstone. Here the Entrada Sandstone grades laterally into the Preuss Formation.

Aspects of depositional environments of the Entrada Sandstone have been studied in part (Kocurek, 1981; Vincellet and Chittum, 1981;
Kocurek and Dott, 1983; Rubin and Hunter, 1983; Lucas et al., 1985; Peterson, 1986; Condon and Peterson, 1986), but, as with most of the eolian units of the western United States, a detailed, regional synthesis has not yet been attempted. Complex facies changes and vertical and lateral differences in the style of cross-strata occur across the region. In a broad view, however, regional patterns are evident. The main body of the Entrada consists of erg-sabkha-shallow marine deposits. Parts of the system represented primarily by eolian dune deposits occur in Colorado and eastern New Mexico; sandy, silty-sandy, sabkhashallow marine deposits characterize the westernmost portions of the system. Between these facies are units characterized by alternating cross-stratified and flat-bedded deposits. Flat-bedded deposits almost certainly represent thick interdune deposits and inland sabkhas. Areas also marked by the accumulation of primarily dune cross-strata occur near the southern limits of the outcrop in north-central Arizona and western New Mexico. These outcrops mark a southern, inland erg that extended an unknown distance southward toward the volcanic arc. A possible inland sabkha deposit extends around the north and east flanks of the Defiance uplift and is represented by the beds at Baby Rocks. Flat-bedded units present in areas adjacent to the Ancestral Rockies and on the High Plains probably represent sand-sheet and alluvial systems. Judging by the thinning of strata toward the Ancestral Rockies and the facies change from dune to sand-sheet deposits, parts of the Front range and Uncompahgre Plateau formed positive features during Entrada time.

\section{Middle Jurassic IV}

Figure 28 and accompanying cross-sections (Fig. 29C, D, E, F) illustrate the thickness and distribution of the upper member of the Entrada Sandstone in west-central Utah, the Cow Springs Member of the Entrada Sandstone in Arizona and New Mexico, and the sandstone at Mesita in New Mexico.

The upper member of the Entrada Sandstone represents an eolian sandstone depocenter that overlies largely sabkha deposits of the middle member of the Entrada Sandstone. The upper 
member is unconformably overlain by marine deposits of the Curtis or Summerville Formations or the Romana Sandstone, and may be at least equivalent to the upper part of the middle member of the Entrada Sandstone elsewhere. The upper member of the Entrada Sandstone largely occupies the Circle Cliffs basin or trough, with an isopach pattern similar to that of the underlying lower and middle members. Lateral relationships of the upper member are poorly understood, largely because much of the unit was removed prior to deposition of overlying rocks but also because many critical areas are concealed or were removed by erosion (Fig. 28).

The Cow Springs Member of the Entrada has been recognized as a distinct unit within the Entrada (Peterson, in press). The unit retains formation status in the southern San Juan basin pending additional studies. As seen in Fig. 29E, the Cow Springs forms a northwest-southeast elongate body. Progressing northwestward the member apparently grades into the upper part of the middle member of the Entrada Sandstone in north-central Arizona. The northeastern boundary of the Cow Springs is a facies change primarily into silty mudstones of the Wanakah Formation. The Cow Springs is broadly interpreted as a later-phase erg of the Entrada Sandstone that existed inland from sabkha or restricted marine deposits represented by the Wanakah Formation or middle member of the Entrada. Its distribution may partly reflect the nature of preservation beneath the J-5 unconformity. Facies patterns within the Cow Springs show a clear northeastward decrease in the percentage of cross-stratified sandstone toward facies change into the Wanakah Formation.

The sandstone at Mesita (Condon, 1985a, b; Condon and Peterson, 1986) is a predominantly eolian unit in the southeastern San Juan basin of northwestern New Mexico that was formerly assigned to the Bluff Sandstone (Rapaport et al., 1952) or to the Bluff and Zuni Sandstones (Maxwell, 1976, 1982). The Mesita is divided into lower and upper parts (Condon, 1985a, b) that we here tentatively correlate with the Cow Springs Sandstone and the Recapture Member of the Morrison Formation, respectively; this relation is reflected in the isopach map (Fig. 28).
Middle Jurassic $V$

Following O'Sullivan (1980a, b, 1981a, b) and O'Sullivan and Pierce (1983), the Moab Tongue of the Entrada Sandstone is distinguished by bedding style from the underlying and laterally adjacent Slick Rock Member. The Moab Tongue consists of one to a few large sets of cross-strata, and the Slick Rock Member consists of interbedded thin sets of cross-strata and silty, red, flat-bedded units. Using this criterion, the Moab Tongue is restricted to a fairly small part of southeastern Utah. Earlier, Wright et al. (1962) used different, but now considered unreliable, criteria to trace the Moab Tongue into southwestern Colorado.

The Moab Tongue reaches a maximum thickness of about $34 \mathrm{~m}$ along the northeast side of the Monument uplift (Fig. 30). To the northwest, the tongue is replaced laterally by red beds in the lower part of the lower Summerville Formation of McKnight (1940), now the Curtis Formation (Fig. 29C). Here the Moab Tongue is overlain by the restricted marine Summerville Formation, and separated from the Slick Rock Member by the lowermost lower Summerville Formation of McKnight (1940). This lower tongue of Summerville pinches out eastward so that the Moab Tongue directly overlies the Slick Rock Member. Southeastward, most of the Summerville that lies above the Moab is truncated by the J-5 unconformity. O'Sullivan (1980b) showed that Summerville redbeds overlying the Moab are truncated eastward by the sub-Morrison unconformity. However, more recent but as yet unpublished work by R.B. O'Sullivan (pers. commun., 1986) indicates that a thin part of the Summerville does continue eastward to merge with similar redbeds at the top of the Wanakah Formation in southeastern Utah. Hence, the Moab is succeeded by restricted marine, sabkha, or tidal-flat(?) deposits.

In the northeastern portion of the outcrops, the Moab Tongue grades into the Slick Rock Member (Fig. 29C). Similarly, to the south the tongue breaks into numerous cross-stratified and flat-bedded units included in the Slick Rock Member. At the southern localities, a thin wedge of the Wanakah Formation lies on the Moab Tongue and separates it from the overlying J-5 unconformity. 
The Moab Tongue represents a small coastal erg that lay adjacent to the Curtis Seaway to the north and west. The erg prograded or retreated in response to transgression or regression of the Curtis Seaway. The relation between the Slick Rock erg and the Moab erg is not clear. Although eastern and southern beds equivalent to the Moab are included in the upper part of the Slick Rock Member, the distinction is based on mapable criteria and is not necessarily genetic. Where the two units are distinguished, the distinctly different bedding styles described above indicate different erg environments. To the west of the Green River in Utah, the J-3 unconformity occurs at this stratigraphic position, but it has not been recognized where the Moab Tongue overlies the Slick Rock Member. The question, therefore, can be posed as two alternatives: (1) the Slick Rock erg persisted to the east and south through deposition of the Moab erg and the bedding change from the Slick Rock to the Moab reflects a lateral change in eolian processes; or (2) the Moab erg was later and distinct from the Slick Rock erg, and the bedding change from the Slick Rock to the Moab reflects a vertical change in eolian processes. The position of the Summerville and Wanakah Formations conformably overlying the Moab Tongue suggests that the Moab erg was terminated by a marine transgression.

\section{Middle Jurassic VI eolian deposits}

Eolian strata of late Middle Jurassic age, other than the slightly older Moab Tongue of the Entrada Sandstone, are present in the Romana Sandstone, which is the youngest formation of the San Rafael Group in south-central Utah and northcentral Arizona (Fig. 31; Peterson, in press). The Romana is a southern sandstone facies of the Summerville Formation and both are unfossiliferous but considered late Middle Jurassic (late Callovian) in age based on regional relationships with fossiliferous strata farther north (Imlay, 1980). Tabulated data used for this study are given in Table 6 and the data points are shown on Fig. 21.

The Romana was deposited in marginal marine and continental environments at the southern end of the Summerville sea, a large marine embayment that extended southward across Utah and into northernmost Arizona. Eolian strata are only present in the upper part of the Romana in the southwestern part of the Kaiparowits Plateau in southcentral Utah (Fig. 32).

The Romana Sandstone occupies a structural trough or basin that coincides fairly well with the present-day Kaiparowits structural basin (Peterson, 1986). At the base, the formation contains a red mudstone or siltstone marker bed that is a tongue of the Summerville Formation. The tongue marks the greatest extent of the Summerville seaway into southern Utah and northernmost Arizona (Peterson, in press). The red marker bed pinches out by onlap on the flanks of the trough, indicating flexing of the trough, probably just before as well as during deposition of the formation. Regional studies indicate that the red mudstone marker connected with Summerville red beds to the northwest and that the Kaiparowits region was a structural trough open to the northwest at this time (Peterson, 1986). However, the same studies also indicate that a closed basin developed by uplift along the northwest flank of the basin during the erosion interval that resulted in the $\mathrm{J}-5$ unconformity. Deformation continued after deposition throughout the basin, though, as the peripherally wedging form of the entire formation suggests (Fig. 31). Romana eolian deposits are only present on the southwest flank of the Kaiparowits trough.

Eolian beds in the Romana constitute a progradational wedge on the southwest side of the marine embayment and were deposited during withdrawal of the seaway. The formation as well as the eolian beds within it are truncated southwestward beneath the J-5 and sub-Dakota unconformities, making it difficult to hypothesize the original extent of the dune field although the following line of reasoning suggests that the field was fairly small. The eastward extent of the eolian beds was against the seaway; the westward extent may have been the Echo Cliffs-Kaibab uplift, which is known to have been a positive structural element at this time (Peterson, 1986). The noneolian part of the Romana contains coarse sand, granules and small pebbles (chert and scarce quartzite) as much as a centimeter in diameter and 
B

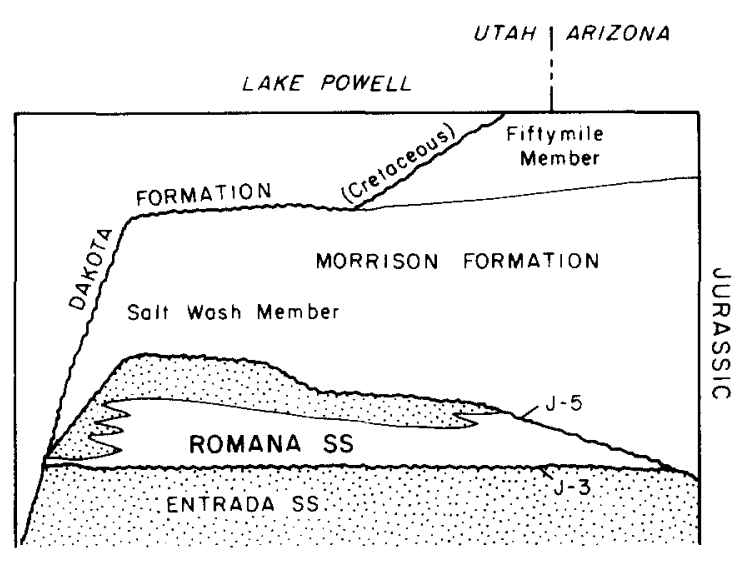

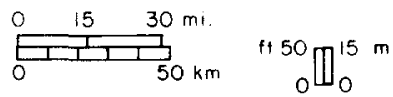

Fig. 32. Restored cross-section of Middle Jurassic VI eolian deposits of the Romana Sandstone. Location shown on Fig. 21.

the size of this material increases westward or landward (Peterson, in press). The coarse material is thought to have been carried into the region by streams although fluvial channel deposits have not yet been identified in the formation. The coarse material must have come from west of the Echo Cliffs-Kaibab uplift as the Entrada Sandstone, the formation exposed on the uplift at this time, does not contain such coarse material. Additionally, the sand in the eolian deposits of the Romana is slightly coarser than the sand in the Entrada, indicating that the Entrada was not the only source of sand in the Romana dune field.

All of these features suggest that streams flowing from a highland source region far to the west, perhaps off the Colorado Plateau, carried sand, granule, and small pebble-sized debris into southcentral Utah. There, westerly winds (documented in Peterson, this volume) picked up some of the finer constituents and transported them farther eastward to form the Romana dune field along the shoreline of the Summerville seaway and on the west side of the structural and topographic low that lies east of the Echo Cliffs-Kaibab uplift. The western limit of the dune field may have been governed not only by the uplift but also by the streams, which may have had sufficient energy to remove much if not all of the eolian sand that might have accumulated in their pathways. The southern extent of the dune field is unknown as the beds have been removed by erosion in that direction. The northward extent of the dune field is unknown because the formation is truncated northward in the western part of the Kaiparowits basin (Peterson, 1986). However, no eolian strata are present farther north where approximately age-equivalent continental beds are present in the Summerville Formation (Peterson, in press). Thus, the available evidence suggests that Romana eolian deposits formed a narrow belt, perhaps of limited extent, along the shoreline of the Summerville embayment. This argument also suggests that the Romana coastal dune field was smaller than most of the other units discussed in this paper.

A southwestward increase in percent eolian sandstone in the Romana is shown on Fig. 31. Although this is probably a fair indication of the original trends of eolian sandstone content in the formation, the map is somewhat misleading. The Romana was abruptly beveled southwestward by the J-5 and sub-Dakota unconformities and this resulted in southwestward removal of eolian beds, which lie in the upper part of the Romana, before the underlying non-eolian beds were truncated. With this in mind, the percent of eolian sandstone in the original formation probably would have increased southwestward at a greater rate than indicated on the map. The round northeastward bulge of the contour lines may also be a partial reflection of truncation of eolian beds at the top of the Romana beneath the J-5 and sub-Dakota unconformities and the somewhat arcuate shape of the southwest flank of the Kaiparowits basin or trough.

\section{Upper Jurassic eolian deposits}

\section{Introduction}

Upper Jurassic eolian strata are present in the Morrison Formation or related strata that lie between the J-5 unconformity and overlying Cretaceous rocks. The most extensive eolian beds or areas known to contain them are present in four broad areas in the Western Interior that are de- 
scribed and discussed in succeeding paragraphs. Considerably smaller eolian beds or lenses are present elsewhere in southern Utah and southwestern Colorado (Peterson, 1980) but they are not included in this study owing to their small areal extent. According to Imlay's (1980) regional studies, these beds are Late Jurassic (late Oxfordian, Kimmeridgian and early Tithonian) in age. The data for constructing the isopach maps are given in Table 6; the isopach and facies map is Fig. 34, and the location of data points is on Fig. 21. Late Jurassic tectonic elements varied somewhat from the Middle Jurassic and are shown on Fig. 33. Restored cross-sections of this interval are shown on Fig. 35.

\section{Unkpapa Sandstone}

The Unkpapa Sandstone is on the east flank of the Black Hills in western South Dakota (Fig. 34) and is a likely correlative to basal Morrison sandstone beds on the west side of the Black Hills (Robinson et al., 1964, p. 20). The bedding in this package of beds has been largely or entirely obliterated in most places by unknown causes. Despite these problems, field and petrographic studies by Szigeti and Fox (1981) left the conclusion that it is predominantly eolian in origin. The Unkpapa interfingers with the Morrison Formation and is so closely related to it that Szigeti and Fox (1981) felt it should be considered a member of the Morrison.

The Unkpapa Sandstone and presumably correlative sandstone beds at the base of the Morrison Formation are on the flanks of the Black Hills uplift in western South Dakota and eastern Wyoming (Figs. 34 and 35A). Correlation with basal Morrison sandstone beds on the northwest flank of the uplift is not certain but seems reasonable (Robinson et al., 1964). As contoured from the available surface information, the Unkpapa and related units are restricted to the structural high marked by the Black Hills uplift, a structural feature known to have been active in Jurassic and Cretaceous time (Robinson et al., 1964). Studies by McKee et al. (1956) and Szigeti and Fox (1981) suggest that the sandstone continues southeast from the Black Hills, but whether or not it is eolian in that area has not, to our knowledge, been determined.

The Unkpapa dune field apparently was surrounded by lacustrine environments represented by mudstone layers in the Morrison Formation (Szigeti and Fox, 1981). As the region subsided, the dune field was inundated and eventually covered by lacustrine deposits. Destruction of bedding in the formation may have been caused by chemical reactions between the lacustrine waters and labile grains or possibly by burrowing organisms.

Judging from descriptions in the literature, the percent of eolian sandstone is highest (as much as $35 \%$ ) in the southern part of the Black Hills (Fig. 34). The thickest part of the Unkpapa (69 m) is in this general area and the rocks probably lay above the level of Morrison lake waters for a longer time than surrounding areas. Thus, if destruction of some of the sedimentary structures is related to chemical reactions with lake waters, the relatively high percentages of cross-bedded sandstone in this area might reflect nothing more than less time in contact with the lake waters.

\section{Central Wyoming eolian deposits}

Scattered eolian sandstone lenses are present in the lower part of the Morrison Formation throughout a large part of central Wyoming. These units were not recognized until recently and studies on them are still in progress (D.M. Uhlir, pers. commun., 1986); hence, an adequate isopach map could not be constructed. However, a map showing the approximate area in which these eolian sandstone bodies have been found is given in Fig. 34. The area outlined on this map was found by preparing an isopach map of the lowest sandstone unit in the Morrison Formation from the available literature (none of which indicated the depositional environment) and, where necessary, adjusting this to fit the distribution of cross-bedding dip-vector resultants obtained from the eolian units and kindly furnished by D.M. Uhlir (pers. commun., 1986) or obtained by one of us (FP; see Peterson, this volume, for the distribution of the resultants). The isopach map is not included in this report because the data are inadequate and 
misleading. The eolian beds are at or near the base of the Morrison Formation and generally lie in depositional contact on the Windy Hill Member, the youngest unit in the Sundance Formation (Fig. $35 \mathrm{~A}$ ). The J-5 unconformity is at the base of the Windy Hill and the Windy Hill interfingers with Morrison strata (Pipiringos, 1968), making that member more closely related to the Morrison than to the rest of the Sundance. The relationship of the eolianites to the Unkpapa Sandstone and related beds around the Black Hills is not clear although stratigraphic position low in the Morrison Formation and near the J-5 unconformity demonstrates that they are equivalent or nearly equivalent in time. The configuration of the central Wyoming eolianites and the Unkpapa as well as its Black Hills correlatives might be interpreted as an indication that a structural downwarp lay between these two areas. Instead, we suggest that this reflects a lack of data in the Powder River basin and may or may not relate to structural downwarping there.

\section{Bluff Sandstone Member of Morrison Formation and Junction Creek Sandstone}

The Bluff Sandstone Member of the Morrison Formation along with its correlative-the Junction Creek Sandstone-is part of a large eolian sandstone complex on the east side of the Colorado Plateau (Figs. 34 and 35B). The name Bluff Sandstone Member is used for the part of this complex in southeastern Utah and northeasternmost Arizona, whereas the name Junction Creek Sandstone is used for essentially the same stratigraphic unit in southwestern Colorado and northwesternmost New Mexico. Equivalency of the two units and their continuity as a single entity has been recognized ever since Goldman and Spencer (1941) established the Junction Creek as a separate formation. The Bluff is Late Jurassic (late Oxfordian-Kimmeridgian Ages) because it intertongues with the Tidwell and Salt Wash Members of the Morrison Formation (also of late Oxfordian and Kimmeridgian Ages according to Imlay, 1980). Because of their time-equivalency, the Junction Creek must be of the same age. Thus, an indication that the Junction Creek is late Middle Jurassic in age (late Callovian Age) by Imlay (1980, p. 75) is in error. Bluff has priority of nomenclature (Baker et al., 1936) over Junction Creek (Goldman and Spencer, 1941) but thus far no one has suggested dropping Junction Creek and applying the name Bluff to the entire complex.

The Bluff-Junction Creek eolian complex is highly irregular in plan view and reaches its greatest thickness of $131 \mathrm{~m}$ in southwestern Colorado, but three other thick areas are on lobes that extend south, west and northeast from there (Fig. 34).

For the most part, the relationship of the eolian complex to active structures is indirect as it tends to lie in intermediate areas between structural lows and highs. An exception is the northeast lobe, which tends to be thickest on top of the Late Jurassic Uncompahgre uplift. The westernmost part of the eolian complex lies just east of the southern part of the Monument uplift where stratal relationships with the Salt Wash Member of the Morrison suggest that vertical movement on the uplift played a role in determining the location of at least the western part of the dune field.

The Salt Wash Member of the Morrison Formation was deposited by streams that flowed northeastward and eastward, entering the Colorado Plateau province from the west and southwest and forming a broad alluvial complex across the middle of the Colorado Plateau. Lack of Salt Wash fluvial strata above the thickest part of the Bluff (O'Sullivan, 1965) indicates that the streams divided and flowed around the Bluff dune field, but it seems unlikely that unconsolidated dune sands could have withstood the erosive power of Salt Wash streams without some agent other than the sheer bulk of the dune field to divert the streams. The Monument uplift was an active structural element during all of the Jurassic Period and played a significant role in influencing the distribution of Morrison sediment (Peterson, 1984, 1986). Positive movement in the Monument region resulted in a topographic high in the southern part of the uplift. The high divided the Salt Wash alluvial complex into two lobes that extended eastward on either side of the Bluff dune field, which lay just east of the Monument topographic high (Peterson and Tyler, 1985). The dune field 


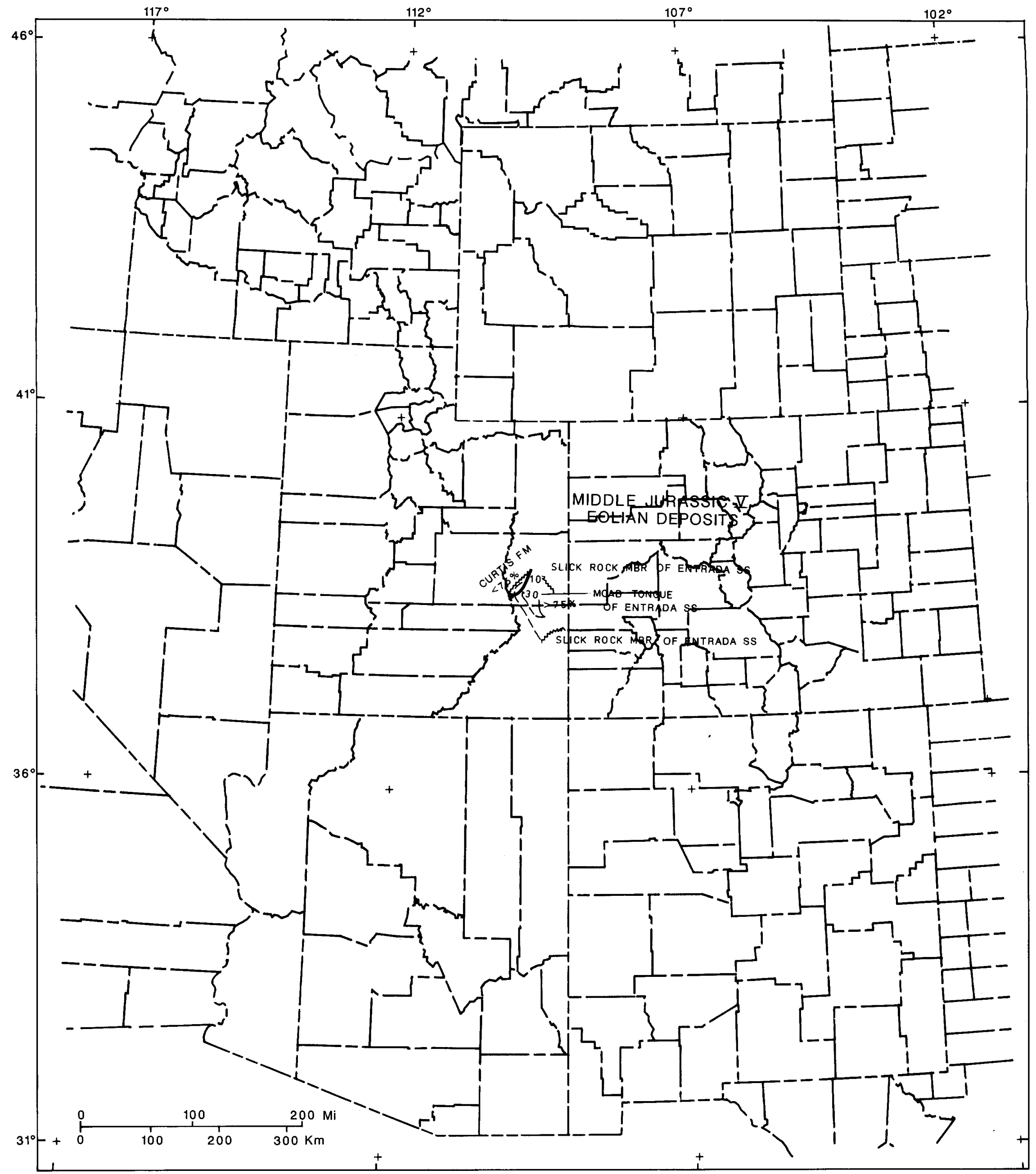

Fig. 30. Geometry and facies relations of Middle Jurassic V eolian deposits. Heavy lines show approximate percentage of eolian sandstone. Isopach interval 10 and $20 \mathrm{~m}$. Solid lines where outcrops occur; dashed lines where interval in subsurface or removed by erosion. 


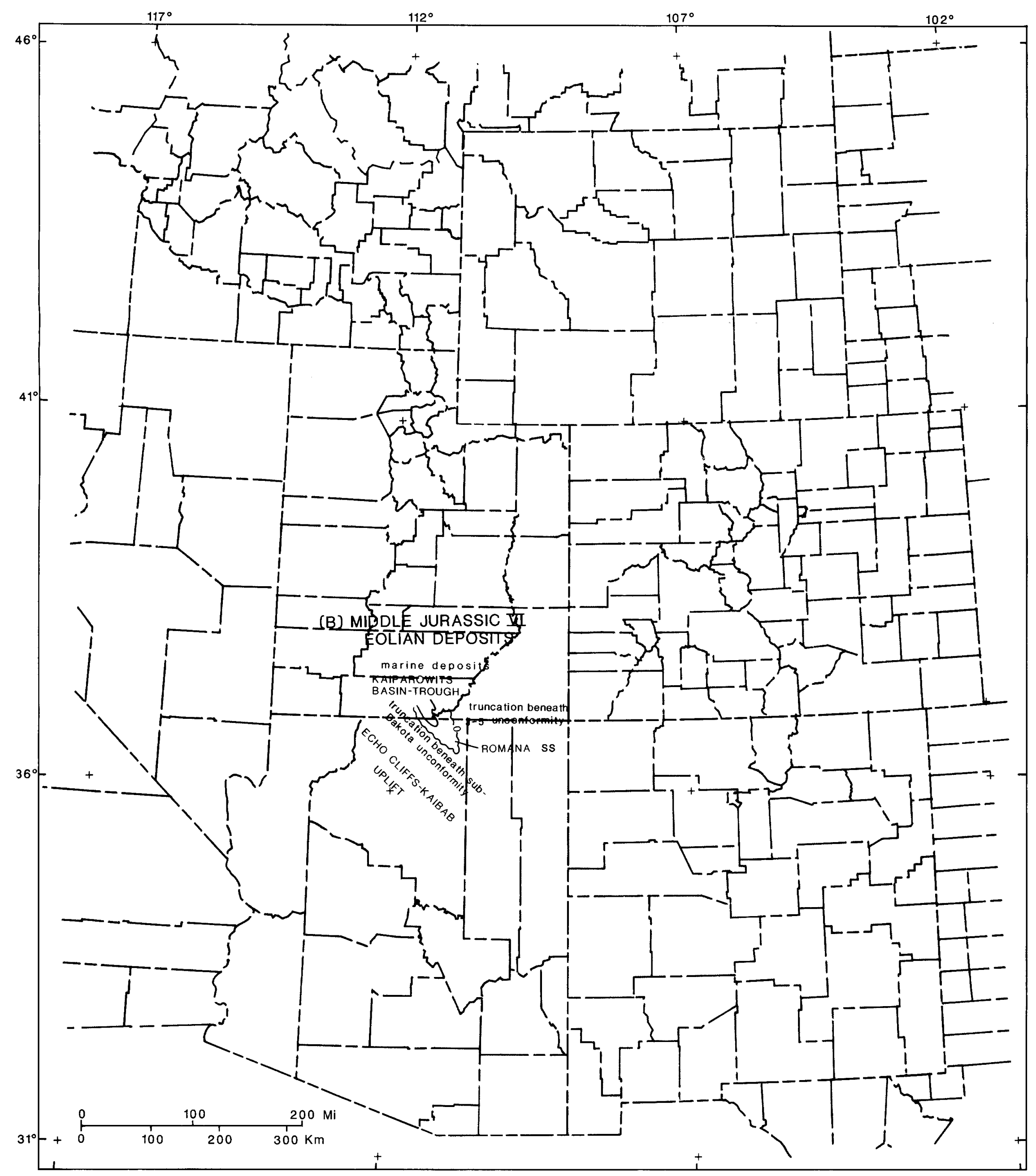

Fig. 31A. Geometry of Middle Jurassic VI eolian deposits. Isopach interval $30 \mathrm{~m}$. Solid lines where outcrops occur; dashed lines where interval in subsurface or removed by erosion. 


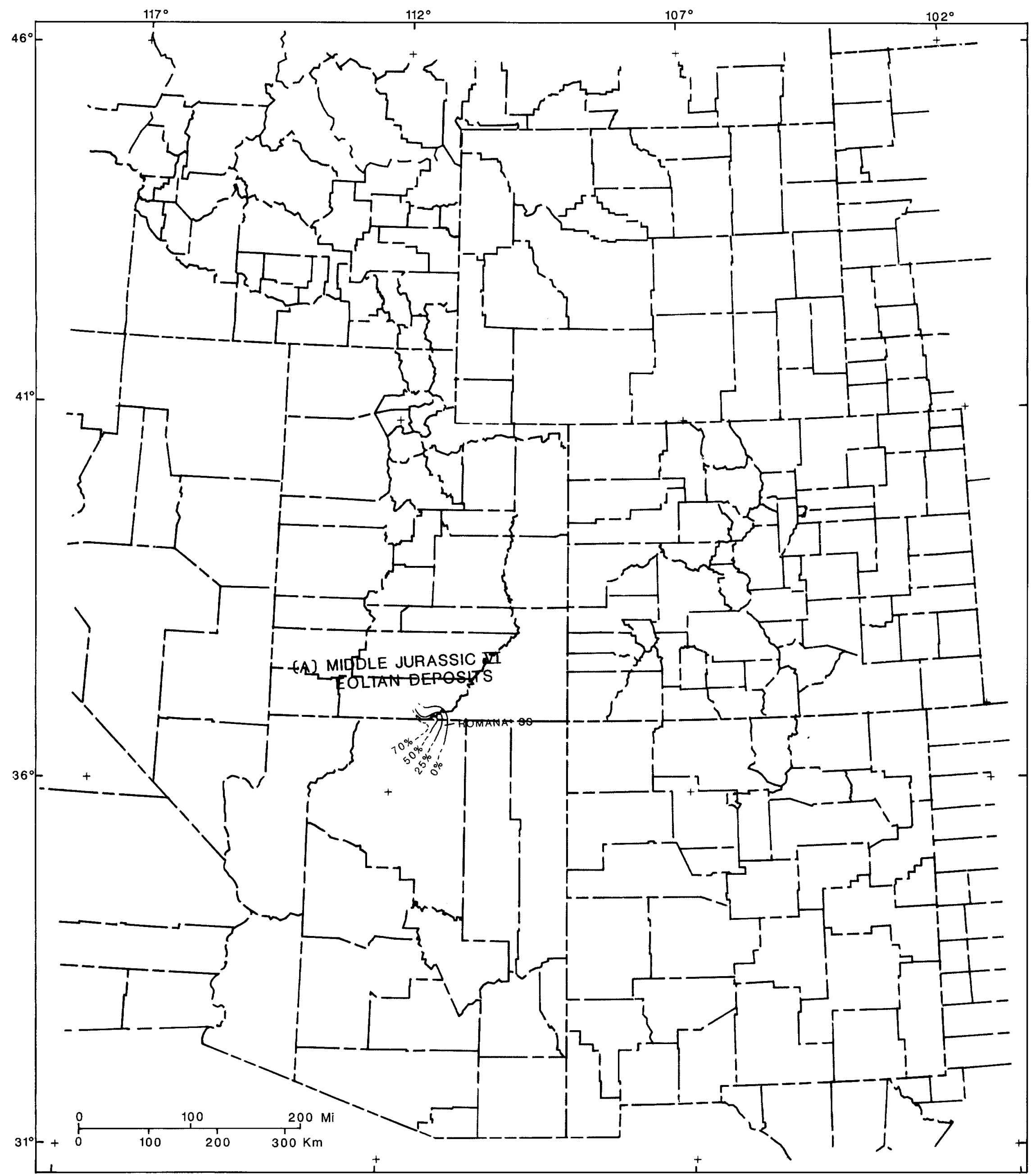

Fig. 31B. Facies relations of Middle Jurassic IV eolian deposits. Isopach interval $30 \mathrm{~m}$. Solid lines where outcrops occur; dashed lines where interval in subsurface or removed by erosion. 



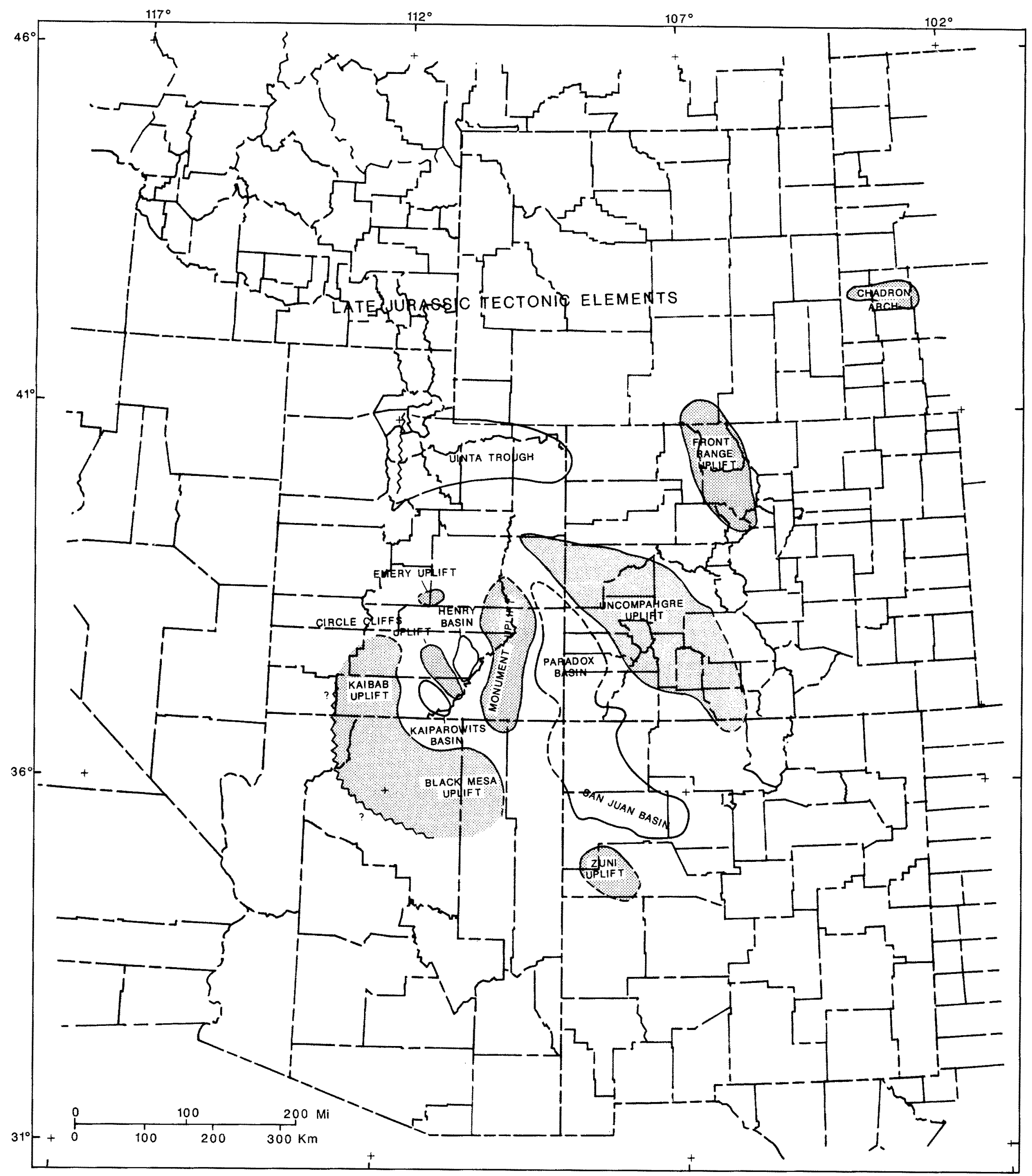

Fig. 33. Generalized Late Jurassic tectonic elements that influenced sedimentation of Morrison-age eolian deposits. Boundaries are approximate and varied through time. 


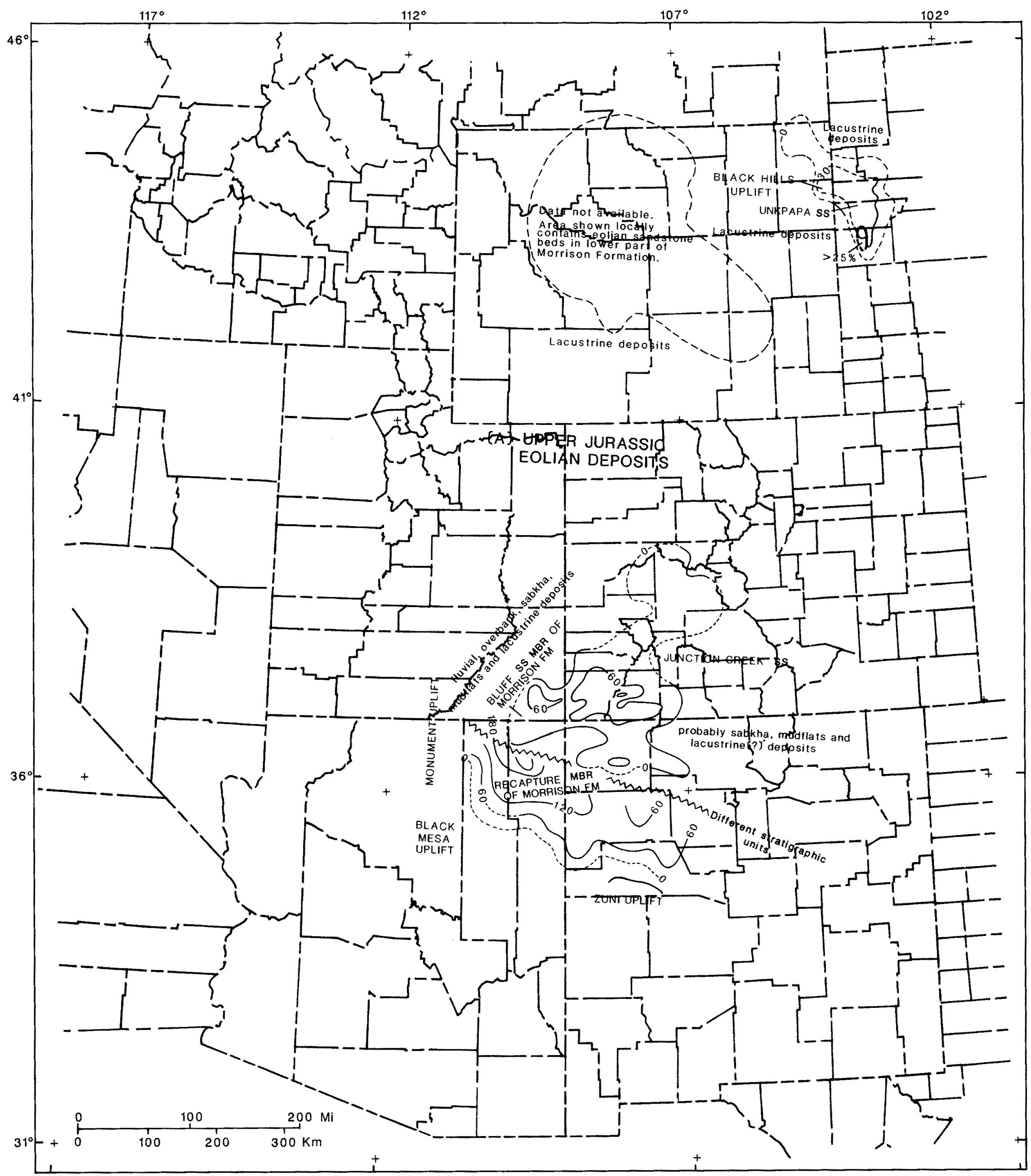

Fig. 34A. Geometry of Upper Jurassic eolian deposits. Detailed regional correlation uncertain. Isopach interval 30 and $60 \mathrm{~m}$. Insufficient data to contour deposits in central Wyoming. Solid lines where outcrops occur; dashed lines where interval in subsurface or removed by erosion. 


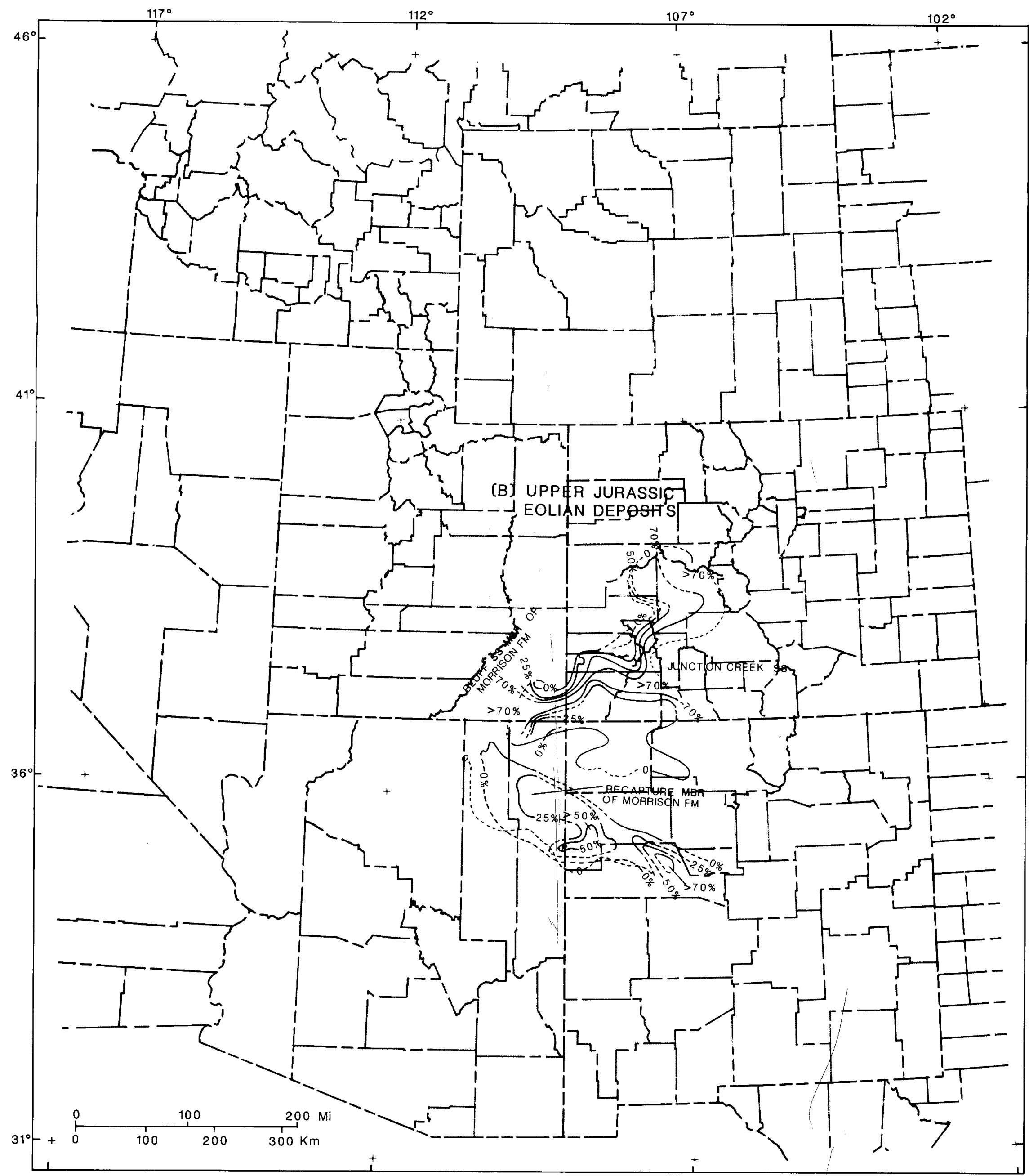

Fig. 34B. Facies relations in Upper Jurassic eolian deposits. Detailed regional correlation uncertain. Isopach interval 30 and $60 \mathrm{~m}$. Insufficient data to contour deposits in central Wyoming. Solid lines where outcrops occur; dashed lines where interval in subsurface or removed by erosion. 

lay in a sheltered lowland area protected from Salt Wash fluvial processes by the Monument high. Westerly to southwesterly winds transported the eolian sand (Peterson, this volume), indicating that it was derived largely from the Salt Wash alluvial complex farther west. The topographic high also produced a turbulent area on its leeward side that favored the accumulation of wind-borne sand. The structurally deepest part of the Late Jurassic San Juan basin lay a few tens of kilometers south of the Bluff-Junction Creek eolian complex (Santos and Turner-Peterson, 1986), so the sand accumulated on a structural slope or bench on the northern flank of that basin. This compares well with the structural-topographic setting of the Permian Schnebly Hill-De Chelly eolian-bearing sequence on the sloping flank of the Holbrook basin.

The area of highest percentages of crossbedded sandstone in the Bluff-Junction Creek forms a sinuous belt extending northeastward from the Monument high in southeastern Utah (Fig. 34). The belt lies roughly parallel to wind flow (Peterson, this volume) and tends to lie either along the thickest part of the complex or on the downwind side of the northeast-trending lobe of the complex. Although the Bluff and Junction Creek are readily identified on drill hole logs, no attempt was made to interpret the percent of eolian sandstone from

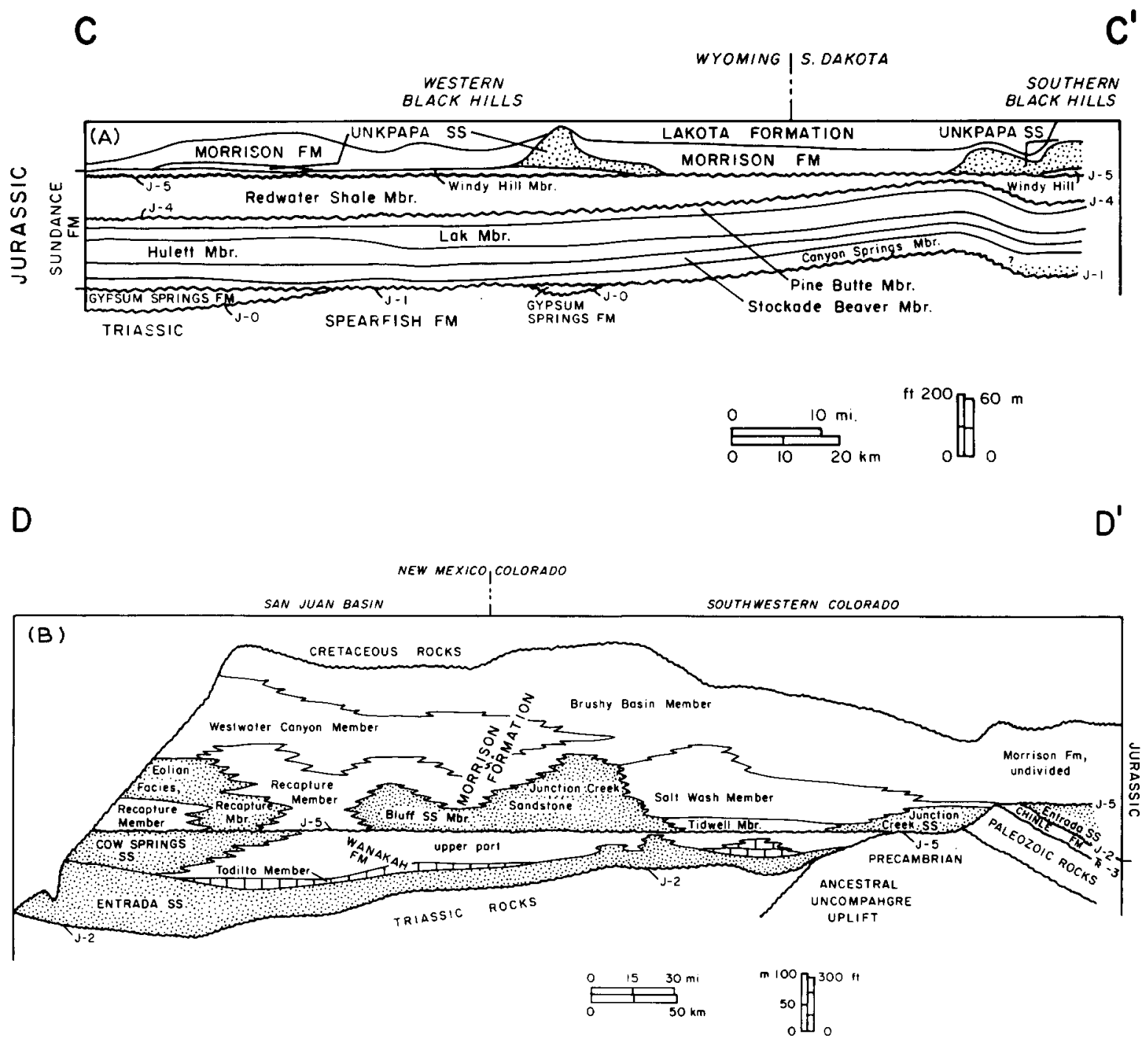

Fig. 35. Restored cross-sections of Upper Jurassic eolian deposits of the Morrison Formation. Locations shown on Fig. 21. 
the logs so the contour lines are not extended into the subsurface.

\section{Recapture Member of Morrison Formation}

Eolian strata are most abundant in the lower part of the Recapture Member of the Morrison Formation in the southern part of the Colorado Plateau (Figs. 34 and 35B), although scarce lenses occur higher and, at one locality in the southern part of the San Juan basin, a small lens is at the top of the member. Because many Recapture eolian beds are lenticular and irregularly distributed, they could not be readily distinguished as a separate entity that could be isopached by itself. For this reason, the thickness of the entire member is depicted on Fig. 34. Because some of the eolian beds are at a stratigraphically higher position than the Salt Wash Member, eolianites in the Recapture are late Oxfordian, Kimmeridgian and early Tithonian in age (Imlay, 1980), ranging slightly younger than those in the Bluff-Junction Creek complex.

The method of depicting the percent crossbedded eolian sandstone is different on this map than for the other units in this study where the percentages are based solely on surface measurements. Recapture measurements made at the surface show the percent cross-bedded eolian sandstone reported in the literature but, because it was felt that the underground extent of the eolian beds should be shown, subsurface drill hole logs had to be used even though they are not entirely satisfactory and the results obtained from them are not directly comparable to surface measurements. The percentages obtained from the logs were based on electric-log characteristics of the eolian beds, which have a blocky pattern (low SP and high resistivity) reflecting higher porosity of the eolian sandstone compared to that in fluvial and overbank sandstone. A distinction between cross-bedded and flat-bedded sandstone cannot be made by this method so the values obtained are considered maximum possible values of eolian sandstone in the Recapture. Although this method has its obvious drawbacks, it yields a reasonably accurate indication of the extent of the eolian strata.
Where studied, the Recapture reaches a maximum thickness of at least $207 \mathrm{~m}$ in northeastern Arizona (Fig. 34). Abrupt southwestward thinning reflects beveling beneath the early Late Cretaceous Dakota Formation. The entire extent of the member was not studied as only the part shown on the map contains eolian strata.

The percent cross-bedded eolian sandstone decreases northeastward, southwestward and northwestward, reflecting both facies changes and postdepositional beveling (the member is beveled by Cenozoic unconformities to the southeast). The northeast and northwest drop in percentages reflects loss of eolian sandstone in those directions where the eolian strata grade into beds interpreted as fluvial, overbank floodplain, mudflat and lacustrine in origin. Northeastward gradation into non-eolian deposits most likely reflects subsidence along the axis of the ancestral San Juan basin, whose structurally deepest part lay between the eolian deposits of the Recapture and Bluff-Junction Creek ergs in Jurassic time (Santos and Turner-Peterson, 1986). Presumably, wetter environments inimical to eolian sedimentation existed there as a consequence of the structural and related topographic setting.

Interpretation of the southwestward reduction in values is obscured by southwestward regional beveling beneath the Dakota Sandstone. The greater part of the Recapture dune field lay in the area between the Zuni uplift to the southwest and the deepest part of the San Juan basin to the northeast and its location was determined, partly or largely, by these structural elements. Additionally, the Zuni and Black Mesa uplifts appear to have sheltered the dune field from any northward-flowing streams that might have flowed toward the San Juan basin from the Mogollon highland in south-central Arizona.

Recapture eolian beds lie east and downwind from the Late Jurassic Black Mesa and Zuni uplifts in northeastern Arizona (Peterson, 1986; and this volume) and northwestern New Mexico. The upwind position of these structures appear to have played an important role in the genesis of the dune field, both by diverting streams from the site of the dune field and by providing sufficient topographic relief to disrupt atmospheric circulation 
patterns and foster the accumulation of dune sand farther east.

\section{Conclusions}

Late Paleozoic and Mesozoic erg deposits of the Western Interior dominate much of the "great sand pile", especially on the south-central Colorado Plateau. Apparently sand was fed into the region from the north by northerly winds, westerly flowing rivers, and southerly flowing coastal currents. The ergs initiated, expanded, and waned in response to tectonic, climatic and eustatic events. In terms of present distribution, maximum extent was during the Wolfcampian, Early Jurassic and Middle Jurassic time. With the exception of the latest Permian, Early, Middle and early Upper Triassic, eolian deposits occur somewhere across the region at any given defined interval of time. Such widespread and continuous deposition of eolian sediments is unique, in our experience, in the stratigraphic record.

We hope that this paper provides a service to both those wanting an introduction to eolian depositional systems of the Western Interior and those familiar with the overall stratigraphic and depositional framework. We have attempted to summarize the currently available data for these units, both published and unpublished. Our conclusions and brief discussions are based on great volumes of data, much of which could not be presented or illustrated because of space limitations. If one message or thought is left with the reader, we hope it will be that eolian depositional systems are very complex and that most are in need of additional detailed study. The stereotype of clean, widespread, uniform eolian formations is unrealistic. Margins range from complex, vertically stacked facies changes to thinning tongues or wedges of eolian sandstone. Although a few margins represent simple onlap-offlap pinch-outs, most are associated with facies changes to noneolian deposits.

Correct reconstruction of facies relations and geometric configuration of erg intervals is critical to interpretation of ancient eolian sequences. The major goal of this paper is to present this information so that the depositional history, paleogeography and paleotectonics of the sedimentary rocks of late Paleozoic and Mesozoic age across the Western Interior can be more fully understood.

\section{Acknowledgments}

Many geologists and technical-support people assisted in the preparation of this paper. Larry Middleton of Northern Arizona University assisted with the isopach of the Navajo and Aztec Sandstones. Frank Royse of the Denver office of Chevron Oil Company provided data for the Nugget Sandstone in the thrust belt of Wyoming, Idaho and Utah. The Bilby Research Center of Northern Arizona University provided technical support through the drafting and photography of Emilee Mead and typing of Louella Holter. David Best (Northern Arizona University) and J.E. "Woody" Frezon (USGS, Denver) reviewed the manuscript and provided helpful suggestions for improving the paper. We are indebted to the many tens of field assistants and students who helped the three of us in the field over the many years. Jeff Horowitz of the Department of Geology, University of Texas at Austin, and George Garcia and Carol S. Holtgrewe of the U.S. Geological Survey, Denver, drafted the maps. Bonnie L. Crysdale of the U.S. Geological Survey, Denver, helped with the preparation of the computer-generated base map. 
TABLE 1

Methodology used in construction of each isopach

\begin{tabular}{ll}
\hline Erg interval or name & Isopached interval and comments \\
\hline Pennsylvanian erg deposits & For Tensleep, Weber and Quadrant Sandstones, isopachs show thickness of those units as \\
& currently defined by previous workers. Base of interval is gradational contact and generally \\
& lower several meters varies among workers. Top is major unconformity across most of central \\
& and western Wyoming and adjacent Montana. Pennsylvanian top of Weber after Bissell and \\
& Childs (1958). Casper Formation interval from lowest sandstone considered eolian to red \\
marker horizon of previous workers.
\end{tabular}

Wolfcampian erg deposits

For Cedar Mesa and Queantoweap Sandstones, isopachs show thickness of these units as currently defined by previous workers. Both contacts are locally gradational through several meters. In subsurface of central Utah, all quartz sandstone was considered eolian for isopaching purposes, although this is subject to verification. Esplanade Sandstone of Grand Canyon is isopached from base to top of calcareous cross-stratified sandstone of McKee (1982, his fig. P12) and eolian origin for entire interval is subject to verification. Eolian interval shown in Mogollon Rim occurs at top of Esplanade Sandstone and based on McAllen (1984) and unpublished data by Blakey. Includes Permian parts of Weber, Casper, and Minnelusa Formations from lowest eolian rocks above the red marker bed to highest eolian rocks. Includes Ingleside Sandstone of previous usage.

Leonardian I erg deposits

For De Chelly Sandstone, entire unit on Monument Upwarp; White House member of Peirce (1964) on Defiance Plateau. For Schnebly Hill Formation from base of lowest eolian sandstone to base of Coconino Sandstone. Supplementary contour shows thickness of entire formation in Holbrook Basin.

Leonardian II erg deposits

Includes Type Coconino Sandstone of Grand Canyon and lower Coconino Sandstone in Sedona area as defined in this report. East of line on Fig. 10 includes entire Coconino and Glorieta Sandstones.

Leonardian III erg deposits

Includes Lyons Sandstone as recognized by previous workers. Includes eastern phase of Toroweap Formation (Rawson and Turner-Peterson, 1980) and coeval rocks; White Rim Sandstone of Utah as currently defined; upper Coconino Sandstone of Sedona area as herein defined.

Wingate Sandstone

Includes entire Wingate Sandstone north and west of Kayenta, Arizona; Lukachukai Member south and east of Kayenta (does not include Rock Point Member). Where Dinosaur Canyon Member of Moenave Formation overlies the Lukachukai Member of the Wingate Sandstone, the isopached interval includes both units.

Jelm Formation and Rock Point Member

Includes entire thickness of Jelm Formation. Distribution of known and suspected eolian deposits of Rock Point Member of Wingate Sandstone and coeval deposits of Dolores Formation also shown.

Navajo Sandstone, Nugget Sandstone

Includes entire Navajo and Aztec Sandstones and upper eolian portion of Nugget Sandstone (does not include Bell Springs Member). Where Navajo intertongues with Kayenta Formation along southern and southwestern margin of outcrop, thickness of Navajo tongue(s) included but thickness of intervening Kayenta is not included.

Temple Cap Sandstone

Includes thickness of White Throne Member.

Page Sandstone

Includes thickness of Harris Wash and Thousand Pockets Tongues but does not include thickness of any intervening Carmel Formation.

Entrada Sandstone and related

Includes thickness of eolian-bearing intervals within each defined interval, related, units or member. See text for further discussion.

Morrison erg deposits and re- Includes thickness of eolian-bearing interval. See text for further discussion. lated strata

Key to symbols used in tables: $\mathrm{A}=$ incomplete section; $\mathrm{B}=$ as modified or defined by Blakey for this report; $\mathrm{K}=\mathrm{as}$ modified or defined by Kocurek for this report; $\mathrm{P}=$ as modified or defined by Peterson for this report; PI = Petroleum Information data cards. 
TABLE 2

Data base for Paleozoic eolian deposits

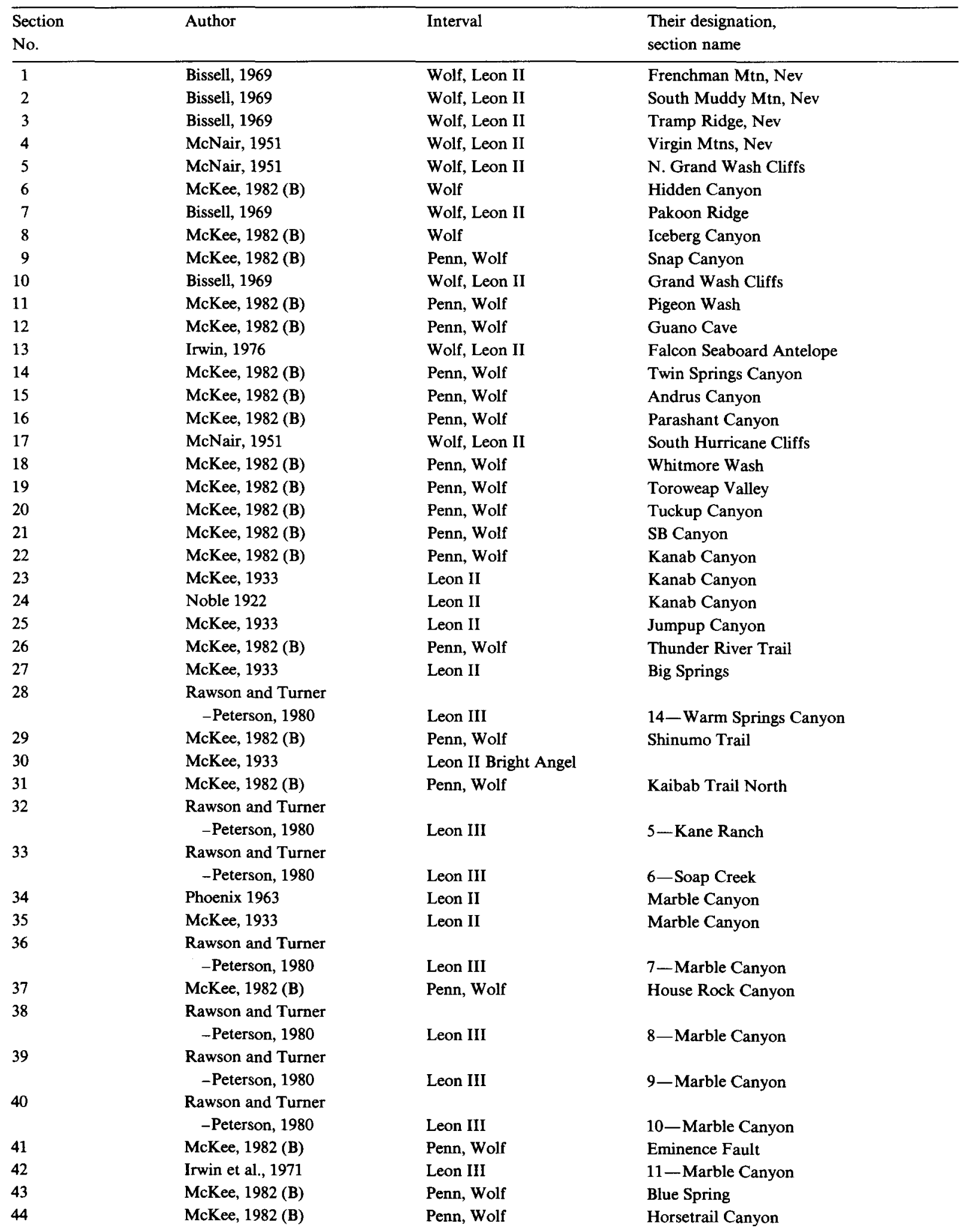


TABLE 2 (continued)

\begin{tabular}{|c|c|c|c|}
\hline $\begin{array}{l}\text { Section } \\
\text { No. }\end{array}$ & Author & Interval & $\begin{array}{l}\text { Their designation, } \\
\text { section name }\end{array}$ \\
\hline \multirow[t]{2}{*}{45} & Rawson and Turner & & \\
\hline & -Peterson, 1980 & Leon III & 12--Desert View \\
\hline 46 & McKee, 1982 (B) & Penn, Wolf & Bunker Trail \\
\hline 47 & McKee 1982 (B) & Penn, Wolf & Grandview Trail \\
\hline 48 & McKee, 1933 (B) & Leon II & Kaibab Trail South \\
\hline 49 & McKee, 1982 (B) & Penn, Wolf & Kaibab Trail South \\
\hline 50 & McKee, 1982 (B) & Penn, Wolf & Hermit Trail \\
\hline \multirow[t]{2}{*}{51} & Rawson and Turner & & \\
\hline & -Peterson, 1980 & Leon III & 15-Bass Trail \\
\hline 52 & McKee, 1982 (B) & Penn, Wolf & Bass Trail \\
\hline 53 & McKee, 1933 & Leon II & Powell Plateau \\
\hline 54 & McKee, 1982 (B) & Penn, Wolf & Topocoba Trail \\
\hline 55 & McKee, 1982 (B) & Penn, Wolf & Havasu Canyon \\
\hline 56 & McKee, 1982 (B) & Penn, Wolf & National Canyon \\
\hline 57 & McKee, 1982 (B) & Penn, Wolf & Prospect Valley \\
\hline 58 & McKee, 1982 (B) & Penn & Separation Canyon \\
\hline 59 & McKee, 1982 (B) & Penn & Hindu Canyon \\
\hline 60 & McNair, 1951 & Leon II & Peach Springs Canyon \\
\hline 61 & McKee, 1982 (B) & Penn, Wolf & Blue Mountain \\
\hline 62 & McNair, 1951 & Leon II & Aubrey Cliffs \\
\hline 63 & McAllen 1984 & Wolf & Chino Point \\
\hline 64 & Blakey, 1979 & Penn, Wolf & Picacho Butte \\
\hline \multirow[t]{2}{*}{65} & Rawson and Turner & & \\
\hline & -Peterson 1980 & Leon III & 16-Ash Fork \\
\hline 66 & Blakey, 1979 & Penn, Wolf & Hell Canyon \\
\hline 67 & Blakey and Knepp, 1987 & Leon I & Chino Valley (the Matterhorn) \\
\hline 68 & Blakey and Knepp, 1987 & Penn, Wolf & Chino Valley (Bear Canyon) \\
\hline 69 & Blakey and Knepp, 1987 & Penn, Wolf & Chino Valley (Perkinsville) \\
\hline \multirow[t]{2}{*}{70} & Rawson and Turner & & \\
\hline & -Peterson, 1980 & Leon III & 17-Tule Canyon \\
\hline 71 & Blakey and Knepp, 1987 & Leon I & Sycamore Canyon \\
\hline 72 & Blakey and Knepp, 1987 & Leon I & Sedona (Loy Butte) \\
\hline 73 & Blakey and Knepp, 1987 & Penn, Wolf & Sycamore Canyon \\
\hline 74 & Blakey and Knepp, 1987 & Leon I & Sedona (Hart Well) \\
\hline 75 & Blakey and Knepp, 1987 & Leon I & Sedona (Capitol Butte) \\
\hline 76 & Blakey and Knepp, 1987 & Leon I & Sedona (West Scheurman Mtn) \\
\hline 77 & Blakey and Knepp, 1987 & Leon I & Sedona (South Scheurman Min) \\
\hline 78 & Cloud, 1983 & Leon II, III & Lee Mountain \\
\hline 79 & Broomhall, 1978 & Leon II, III & West Fork \\
\hline 80 & Blakey and Knepp, 1987 & Penn, Wolf & Sedona (Oak Creek) \\
\hline 81 & McAllen, 1984 & Wolf & Carroll Canyon \\
\hline 82 & Blakey and Knepp, 1987 & Leon I & Sedona (Bell Rock) \\
\hline 83 & Blakey and Knepp, 1987 & Leon I & Sedona (Dry Beaver) \\
\hline 84 & Blakey and Knepp, 1987 & Leon I & Sedona (Beaver Creek) \\
\hline 85 & Blakey and Knepp, 1987 & Leon I & Sedona (West Clear Creek) \\
\hline 86 & Blakey and Knepp, 1987 & Leon I & Fossil Creek \\
\hline 87 & McKee, 1933 & Leon II & Pine \\
\hline 88 & Blakey and Knepp, 1987 & Leon I & Colcord Canyon \\
\hline 89 & Finnell, 1966 & Leon I, II, III & Chediski Peak \\
\hline 90 & Peirce et al., 1970 & Leon I, II, III & Tenneco \#1 Fed \\
\hline 91 & Peirce et al., 1970 & Leon I, II, III & Tenneco \#1-x Ft. Apache \\
\hline 92 & McKay, 1972 & Leon I, II, III & Corduroy Creek \\
\hline 93 & Peirce et al., 1970 & Leon I, II, III & Pan Am N.M. and Az. B-1 \\
\hline
\end{tabular}


TABLE 2 (continued)

\begin{tabular}{|c|c|c|c|}
\hline $\begin{array}{l}\text { Section } \\
\text { No. }\end{array}$ & Author & Interval & $\begin{array}{l}\text { Their designation, } \\
\text { section name }\end{array}$ \\
\hline 94 & Wengerd, 1962 & Leon I, II, III & Pan Am N.M. and Az. No. 1-A \\
\hline 95 & Wengerd, 1962 & Leon I, II, III & Argo 1 State \\
\hline 96 & Wengerd, 1962 & Leon I, II, III & $\mathbf{K}-\mathbf{M}$ Horstenstein \\
\hline 97 & Wengerd, 1962 & Leon I, II, III & Eastern 3, Santa Fe \\
\hline 98 & Wengerd, 1962 & Leon I, II, III & Eastern 1, Santa Fe \\
\hline 99 & Wengerd, 1962 & Leon I, II, III & Gen. Pet. Creager State \\
\hline 100 & McKee, 1933 & Leon II, III & Holbrook \\
\hline 101 & McKee, 1933 & Leon II, III & Winslow \\
\hline 102 & Blakey (unpubl. data) & Leon I, II, III & Mt. Elden \\
\hline 103 & Irwin et al., 1971 & Leon I, II, III & Water Well near Sunset Crater \\
\hline 104 & Baars, 1962 & Leon I, II, III & Burrell-Collins \\
\hline 105 & Baars, 1962 & Leon I, II, III & Sinclair Navajo \#1 \\
\hline 106 & Irwin et al., 1971 & Leon I, II, III & Hopi \\
\hline 107 & Irwin et al., 1971 & Leon I, II, III & Hoskinnini Test \\
\hline 108 & Witkind and Thaden, 1963 & Leon I, II, III & Monument Valley \\
\hline 109 & Read and Wanek, 1961 & Leon I, II, III & South Comb Ridge \\
\hline 110 & O'Sullivan, 1965 & Leon I, II, III & Boundary Butte \\
\hline 111 & Irwin et al., 1971 & Leon I, II, III & East Boundary Butte Shell \\
\hline 112 & Lessentine 1969 & Leon I, II, III & Amarada Black Mountain \\
\hline 113 & Read and Wanek, 1961 & Leon I, II, III & Canyon del Muerto \\
\hline 114 & Read and Wanek, 1961 & Leon I, II, III & Monument Canyon \\
\hline 115 & Peirce, 1964 & Leon I, II, III & Nazlini Canyon \\
\hline 116 & Read and Wanek, 1961 & Leon I, II, III & Buell Park \\
\hline 117 & Read and Wanek, 1961 & Leon I, II, III & Bonito Canyon \\
\hline 118 & Peirce, 1964 & Leon I, II, III & Hunters Point \\
\hline 119 & Read and Wanek, 1961 & Leon I, II, III & Oak Springs \\
\hline 120 & Peirce, 1964 & Leon I, II, III & Black Creek Canyon \\
\hline 121 & Read and Wanek, 1961 & Leon I, II, III & Black Creek North \\
\hline 122 & Irwin et al., 1971 & Leon I, II, III & Hogback oil test \\
\hline 123 & Read and Wanek, 1961 & Leon I, II, III & Black Creek South \\
\hline 124 & Peirce, 1966 & Leon I, II, III & Water well \\
\hline 125 & Perice, 1966 & Leon I, II, III & Brown Petroleum \\
\hline 126 & Welch, 1976 & Wolf & Shivwits Beaver Dam Mtns \\
\hline 127 & Steed, 1980 & Wolf, Leon II & Virgin River Gorge \\
\hline 128 & Irwin, 1976 & Wolf & Cal St. George \\
\hline 129 & Irwin, 1976 & Wolf & Intex-Knowles \\
\hline 130 & Irwin, 1976 & Wolf, Leon II, III & Superior Kanab Creek \#1 \\
\hline 131 & Welch, 1976 (A) & Wolf & Mtn Fuel Shurtz \\
\hline 132 & Welch, 1976 & Leon II, III & Monsanto Bryce \\
\hline 133 & Irwin, 1976 & Leon II, III & Tidewater Johns Valley \\
\hline 134 & Irwin, 1976 & Leon II, III & Tenneco Tropic \# 1 \\
\hline 135 & Lessentine, 1969 & Leon II, III & Calco Upper Valley \\
\hline 136 & Heylmun, 1958 & Wolf, Leon II, III & Midwest Butler Valley \\
\hline 137 & Irwin, 1976 & Wolf, Leon II, III & Tidewater Utah Fed \\
\hline 138 & Irwin, 1976 & Wolf, Leon II, III & Union Judd Hollow \\
\hline 139 & Lessentine, 1969 & Wolf, Leon II, III & Byrd Rees Canyon \\
\hline 140 & Irwin, 1976 & Wolf, Leon II, III & Shell Soda \\
\hline 141 & Read and Wanek, 1961 & Leon I & Nokai Canyon \\
\hline 142 & Mullens, 1960 & Leon I & Clay Hills \\
\hline 143 & Mullens, 1960 & Leon I & Clay Hills \\
\hline 144 & Irwin et al., 1971 & Leon I & Monitor Mesa \\
\hline 145 & Read and Wanek, 1961 & Leon I & Monitor Butte \\
\hline
\end{tabular}


TABLE 2 (continued)

\begin{tabular}{|c|c|c|c|}
\hline $\begin{array}{l}\text { Section } \\
\text { No. }\end{array}$ & Author & Interval & $\begin{array}{l}\text { Their designation, } \\
\text { section name }\end{array}$ \\
\hline 146 & Read and Wanek, 1961 & Leon I & Copper Canyon \\
\hline 147 & Read and Wanek, 1961 & Wolf, Leon I & Hoskinnini Mesa \\
\hline 148 & Read and Wanek, 1961 & Wolf, Leon I & Wide Butte \\
\hline 149 & Read and Wanek, 1961 & Leon I & Upper Gypsum Creek \\
\hline 150 & O'Sullivan, 1965 & Leon I & Boundary Butte area \\
\hline 151 & O'Sullivan, 1965 & Leon I & Moses Rock \\
\hline 152 & Scott, 1960 & Wolf & \\
\hline 153 & Gregory, 1938 & Wolf & Raplee Anticline \\
\hline 154 & O'Sullivan, 1965 & Leon I & San Juan River \\
\hline 155 & O'Sullivan, 1965 & Wolf & Cedar Mesa \\
\hline 156 & Read and Wanek, 1961 & Wolf & Douglas Mesa \\
\hline 157 & Mullens, 1960 & Wolf & Organ Rock Anticline \\
\hline 158 & Sears, 1956 & Wolf & Grand Gulch Plateau \\
\hline 159 & Sears, 1956 & Leon I & Comb Wash (south) \\
\hline 160 & Sears, 1956 & Leon I & Comb Wash (north) \\
\hline 161 & Scott, 1960 & Wolf & \\
\hline 162 & Lewis and Campbell, 1965 & Wolf & South of Elk Ridge \\
\hline 163 & Scott, $19 i 0$ & Wolf & \\
\hline 164 & Thaden et al., 1964 & Wolf & White Canyon \\
\hline 165 & Thaden et al., 1964 & Leon II & Settlement of White Canyon \\
\hline 166 & Irwin, 1976 & Wolf, Leon II, III & Superior Swap Mesa \\
\hline 167 & Davidson, 1967 & Leon II, III & N.B. Hunt Govt. \#1 \\
\hline 168 & Smith et al., 1963 & Wolf, Leon II, III & Pacific Western Teasdale \\
\hline 169 & Smith et al., 1963 (A) & Leon II, III & Fremont River \\
\hline 170 & Irwin, 1976 & Wolf, Leon II, III & Texaco Thous. Lakes Mtn. \\
\hline 171 & Welch, 1976 & Wolf & Mineral Mountains \\
\hline 172 & Welch, 1976 & Wolf & Shell Sunset Canyon \\
\hline 173 & Irwin, 1976 & Wolf, Leon II, III & Phillips Spring Canyon \\
\hline 174 & Heylmun, 1958 & Wolf & Stanolind Cainville \\
\hline 175 & Irwin, 1976 & Wolf & Amax Moroni slopes \\
\hline 176 & Heylmun, 1958 & Leon II, III & Mtn. Fuel Last Chance \\
\hline 177 & Welch, 1976 (A) & Wolf, Leon II, III & Mtn. Fuel Desert Wash \\
\hline 178 & Irwin, 1976 & Wolf, Leon II, III & Skelly Emergy \\
\hline 179 & Hawley et al., 1968 & Leon II, III & Blackwood-Nichols \\
\hline 180 & Irwin, 1976 & Wolf, Leon II, III & Tenneco Pinto Hills \\
\hline 181 & Irwin, 1976 & Wolf, Leon II, III & Belco Henry Mtns \\
\hline 182 & Irwin, 1976 & Wolf, Leon II, III & Richfield Paradox Brown \\
\hline 183 & Baker, 1946 & Wolf & Cataract Canyon \\
\hline 184 & Baker, 1946 & Wolf & Indian Creek \\
\hline 185 & Scott, 1960 & Leon II, III & Shafer Trail \\
\hline 186 & Irwin, 1976 & Wolf, Leon II, III & Sinclair Orange Cliffs \\
\hline 187 & Irwin, 1976 & Wolf, Leon II, III & Murphy Nequoia Arch \\
\hline 188 & Irwin, 1976 & Wolf, Leon II, III & Phillips Dirty Devil \\
\hline 189 & Irwin, 1976 & Wolf, Leon II, III & Continental State \\
\hline 190 & Irwin, 1976 & Wolf, Leon II, III & Superior Hanksville \\
\hline 191 & Irwin, 1976 & Wolf, Leon II, III & Pan Am Nequoia Arch \\
\hline 192 & Irwin, 1976 & Wolf, Leon II, III & Texaco Temple Springs \\
\hline 193 & Scott, 1960 & Leon II, III & Straight Wash \\
\hline 194 & Irwin, 1976 & Wolf, Leon II, III & Superior Iron Wash \\
\hline 195 & Irwin, 1976 & Wolf, Leon II, III & Amax Green River Desert \\
\hline 196 & Hawley et al., 1968 & Leon II, III & Black Box \\
\hline 197 & Irwin, 1976 & Perm, undiff. & Lemm Woodside \\
\hline 198 & Irwin. 1976 & Perm, undiff. & Pan Am Cullen \\
\hline
\end{tabular}


TABLE 2 (continued)

\begin{tabular}{|c|c|c|c|}
\hline $\begin{array}{l}\text { Section } \\
\text { No. }\end{array}$ & Author & Interval & $\begin{array}{l}\text { Their designation, } \\
\text { section name }\end{array}$ \\
\hline 199 & Irwin, 1976 & Wolf, Leon II, III & Shell North Springs \\
\hline 200 & Irwin, 1976 & Perm, undiff. & Atlantic-Richfield Hiawatha \\
\hline 201 & Irwin, 1976 & Perm, undiff. & Skelly Richard Bryner \\
\hline 202 & Irwin, 1976 & Perm, undiff. & Tenneco Clear Creek \\
\hline 203 & Irwin, 1976 & Perm, undiff. & Chevron Stone Cabin \\
\hline 204 & Irwin, 1976 & Perm, undiff. & Continental Federal \\
\hline 205 & Bissell and Childs, 1958 & Penn, Wolf & 5-Rock Creek \\
\hline 206 & Bissell and Childs, 1958 & Penn, Wolf & 6-Moon Lake \\
\hline 207 & Bissell and Childs, 1958 & Penn, Wolf & 7-Yellowstone River \\
\hline 208 & Bissell and Childs, 1958 & Penn, Wolf & 8-Whiterocks River \\
\hline 209 & Bissell and Childs, 1958 & Penn, Wolf & 9-Dry Fork \\
\hline 210 & Bissell and Childs, 1958 & Penn, Wolf & 10-Ashley-Brush Creeks \\
\hline 211 & Bissell and Childs, 1958 & Penn, Wolf & 12-Sheep Canyon \\
\hline 212 & Bissell and Childs, 1958 & Penn, Wolf & 11--Barker Spring \\
\hline 213 & Irwin, 1976 & Penn, Wolf & Atlantic-Rich. Maeser Fed. \\
\hline 214 & Bissell and Childs, 1958 & Penn, Wolf & 13--Split Mountain \\
\hline 215 & Bissell and Childs, 1958 & Penn, Wolf & 14-Diamond Gulch \\
\hline 216 & Bissell and Childs, 1958 & Penn, Wolf & 15-Morris Ranch \\
\hline 217 & Bissell and Childs, 1958 & Penn, Wolf & 16-S.W. Yampa Plateau \\
\hline 218 & Baars, 1962 & Leon I & Stanolind USG 13 \\
\hline 219 & Baars, 1962 & Leon I & Gulf Navajo Fed. 1 \\
\hline 220 & Baars, 1962 & Leon I & Southern Union Stony Butte 1 \\
\hline 221 & Baars, 1962 & Leon I, II, III & Marshall Beal-Miller 1 \\
\hline 222 & Baars, 1962 & Leon I, II, III & Tidewater Mariano Dome \\
\hline 223 & Baars, 1962 & Leon I, II, III & Kettner, Zuni Mountains \\
\hline 224 & Baars, 1962 & Leon I, II, III & Sawyer, Zuni Mountains \\
\hline 225 & Wengerd, 1962 & Leon I, II, III & Skelly Goesling 1 \\
\hline 226 & Wengerd, 1962 & Leon I, II, III & Skelly 1-C Teel \\
\hline 227 & Wengerd, 1962 & Leon I, II, III & Skelly 1-M Teel \\
\hline 228 & Wengerd, 1962 & Leon I, II, III & Huckleberry 1 Fed \\
\hline 229 & Wengerd, 1962 & Leon I, II, III & Spanel-Heinze 1H-SF \\
\hline 230 & Wengerd, 1962 & Leon I, II, III & Spanel-Heinze 1M-SF \\
\hline 231 & Baars, 1962 & Leon I, II, III & Lucero Uplift \\
\hline 232 & Baars, 1962 & Leon I, II, III & Superior San Mateo \\
\hline 233 & Baars, 1962 & Leon I, II, III & Richfield Drouthe-Booth 1 \\
\hline 234 & Baars, 1962 & Leon I, II, III & Avila Odium Fed \\
\hline 235 & Baars, 1962 & Leon I, II, III & Penasco Arroyo \\
\hline 236 & Baars, 1962 & Leon I, II, III & Guadalupe Box Canyon \\
\hline 237 & Bissell and Childs, 1958 & Penn, Wolf & 19-Vermillion \\
\hline 238 & Bissell and Childs, 1958 & Penn, Wolf & 17-Hells Canyon \\
\hline 239 & Bissell and Childs, 1958 & Penn, Wolf & 18-Yampa River Gorge \\
\hline 240 & Bissell and Childs, 1958 & Penn, Wolf & 20-Miller Creek \\
\hline 241 & Bissell and Childs, 1958 & Penn, Wolf & 21-Elk Creek \\
\hline 242 & Bissell and Childs, 1958 & Penn, Wolf & 22-_Glenwood Springs \\
\hline 243 & Bissell and Childs, 1958 & Penn, Wolf & 23-Elby Creek \\
\hline 244 & Bissell and Childs, 1958 & Penn, Wolf & $24-$ Kent \\
\hline 245 & Hoyt, 1963 & Penn, Leon III & Antelope Creek \\
\hline 246 & Hoyt, 1963 & Penn, Leon III & Owl Canyon \\
\hline 247 & Hoyt, 1963 & Penn, Leon III & Cal Meyer 1 \\
\hline 248 & Hoyt, 1963 & Penn, Leon III & Cal UPRR Ferch 1 \\
\hline 249 & Hoyt, 1963 & Penn, Leon III & Dry Creek \\
\hline 250 & Hoyt, 1963 & Penn, Leon III & Dowe Pass \\
\hline 251 & Hoyt, 1963 & Penn, Leon III & Lyons \\
\hline
\end{tabular}


TABLE 2 (continued)

\begin{tabular}{|c|c|c|c|}
\hline $\begin{array}{l}\text { Section } \\
\text { No. }\end{array}$ & Author & Interval & $\begin{array}{l}\text { Their designation, } \\
\text { section name }\end{array}$ \\
\hline 252 & Hoyt, 1963 & Penn, Leon III & British-Am. Wise 1 \\
\hline 253 & Hoyt, 1963 & Penn, Leon III & Shell Colo Nat Bank 1 \\
\hline 254 & Thompson, 1949 & Penn, Leon III & Eldorado Springs \\
\hline 255 & Thompson, 1949 & Penn, Leon III & Ralston Creek \\
\hline 256 & Mallory, 1967 & Penn & 186 \\
\hline 257 & Mallory, 1967 & Penn & 176 \\
\hline 258 & Mallory, 1967 & Penn & 178 \\
\hline 259 & Mallory, 1967 & Penn & 177 \\
\hline 260 & Mallory, 1967 & Penn & 60 \\
\hline 261 & Mallory, 1967 & Penn & 39 \\
\hline 262 & Mallory, 1967 & Penn & 35 \\
\hline 263 & Mallory, 1967 & Penn & 40 \\
\hline 264 & Mallory, 1967 & Penn & 42 \\
\hline 265 & Mallory, 1967 & Penn & 41 \\
\hline 266 & Mallory, 1967 & Penn & 43 \\
\hline 267 & Mallory, 1967 & Penn & 44 \\
\hline 268 & Mallory, 1967 & Penn & 45 \\
\hline 269 & Mallory, 1967 & Penn & 46 \\
\hline 270 & Mallory, 1967 & Penn & 49 \\
\hline 271 & Mallory, 1967 & Penn & 54 \\
\hline 272 & Mallory, 1967 & Penn & 57 \\
\hline 273 & Mallory, 1967 & Penn & $89-\mathbf{A}^{\prime}$ \\
\hline 274 & Mallory, 1967 & Penn & 88 \\
\hline 275 & Mallory, 1967 & Penn & 90 \\
\hline 276 & Mallory, 1967 & Penn & 75 \\
\hline 277 & Mallory, 1967 & Penn & 77 \\
\hline 278 & Mallory, 1967 & Penn & 70 \\
\hline 279 & Mallory, 1967 & Penn & 84 \\
\hline 280 & Mallory, 1967 & Penn & 85 \\
\hline 281 & Mallory, 1967 & Penn & 86 \\
\hline 282 & Mallory, 1967 & Penn & 72 \\
\hline 283 & Mallory, 1967 & Penn & 73 \\
\hline 284 & Mallory, 1967 & Penn & 79 \\
\hline 285 & Mallory, 1967 & Penn & 97 \\
\hline 286 & Mallory, 1967 & Penn & 185 \\
\hline 287 & Mallory, 1967 & Penn & 184 \\
\hline 288 & Mallory, 1967 & Penn & 183 \\
\hline 289 & Mallory, 1967 & Penn & 181 \\
\hline 290 & Mallory, 1967 & Penn & 122 \\
\hline 291 & Mallory, 1967 & Penn & 121 \\
\hline 292 & Mallory, 1967 & Penn & 179 \\
\hline 293 & Mallory, 1967 & Penn & 180 \\
\hline 294 & Mallory, 1967 & Penn & 182 \\
\hline 295 & Mallory, 1967 & Penn & 197 \\
\hline 296 & Mallory, 1967 & Penn & 92 \\
\hline 297 & Mallory, 1967 & Penn & 94 \\
\hline 298 & Mallory, 1967 & Penn & 96 \\
\hline 299 & Mallory, 1967 & Penn & 83 \\
\hline 300 & Mallory, 1967 & Penn & 100 \\
\hline 301 & Mallory, 1967 & Penn & 107 \\
\hline 302 & Mallory, 1967 & Penn & 109 \\
\hline 303 & Mallory, 1967 & Penn & 148 \\
\hline
\end{tabular}


TABLE 2 (continued)

\begin{tabular}{|c|c|c|c|}
\hline $\begin{array}{l}\text { Section } \\
\text { No. }\end{array}$ & Author & Interval & $\begin{array}{l}\text { Their designation, } \\
\text { section name }\end{array}$ \\
\hline 304 & Mallory, 1967 & Penn & 149 \\
\hline 305 & Mallory, 1967 & Penn & 155 \\
\hline 306 & Mallory, 1967 & Penn & 157 \\
\hline 307 & Mallory, 1967 & Penn & 158 \\
\hline 308 & Mallory, 1967 & Penn & 160 \\
\hline 309 & Mallory, 1967 & Penn & 159 \\
\hline 310 & Mallory, 1967 & Penn & 34 \\
\hline 311 & Mallory, 1967 & Penn & 31 \\
\hline 312 & Mallory, 1967 & Penn & 35 \\
\hline 313 & Mallory, 1967 & Penn & 27 \\
\hline 314 & Mallory, 1967 & Penn & 25 \\
\hline 315 & Mallory, 1967 & Penn & 23 \\
\hline 316 & Mallory, 1967 & Penn & 22 \\
\hline 317 & Mallory, 1967 & Penn & 195 \\
\hline 318 & Mallory, 1967 & Penn & 190 \\
\hline 319 & Agatston, 1954 & Penn & Farmers Union Shad-1 \\
\hline 320 & Agatston, 1954 & Penn & Trout Creek \\
\hline 321 & Agatston, 1954 & Penn & Hampton Ranch \\
\hline 322 & Agatston, 1954 & Penn & Middle Fork \\
\hline 323 & Agatston, 1954 & Penn & Buffalo Creek \\
\hline 324 & Mallory, 1967 & Penn & 143 \\
\hline 325 & Mallory, 1967 & Penn & 139 \\
\hline 326 & Mallory, 1967 & Penn & 135 \\
\hline 327 & Mallory, 1967 & Penn & 115 \\
\hline 328 & Agatston, 1954 & Penn & Pass Creek \\
\hline 329 & Agatston, 1954 & Penn & Middle Fork Crazy Woman \\
\hline 330 & Agatston, 1954 & Penn & Carter Rider \# 3 \\
\hline 331 & Agatston, 1954 & Penn & North Fork Crazy Woman \\
\hline 332 & Agatston, 1954 & Penn & Dry Kelly Creek \\
\hline 333 & Agatston, 1954 & Penn & So. Fk. Rock Creek \\
\hline 334 & Agatston, 1954 & Penn & Big Goose Creek \\
\hline 335 & Agatston, 1954 & Penn & Amsden Creek \\
\hline 336 & Agatston, 1954 & Penn & Little Big Horn River \\
\hline 337 & Agatston, 1954 & Penn & Cottonwood Creek \\
\hline 338 & Nomenclature Comm. 1956 & Penn, Wolf & Pure \# 1 Unit \\
\hline 339 & Fryberger, 1984 & Penn, Wolf & True-White B \\
\hline 340 & Fryberger, 1984 & Penn, Wolf & Davis-Larr. Fed.-A \\
\hline 341 & Fryberger, 1984 & Penn, Wolf & NCRA 1-Biggers \\
\hline 342 & Fryberger, 1984 & Penn, Wolf & Tenneco 10-1 \\
\hline 343 & Fryberger, 1984 & Penn, Wolf & Arco 1-USA-Appel \\
\hline 344 & Fryberger, 1984 & Penn, Wolf & Cal Oil-1-Chambers \\
\hline 345 & Nomenclature Comm., 1956 & Penn, Wolf & Stanolino IT-PWW \\
\hline 346 & Nomenclature Comm., 1956 & Penn, Wolf & US Navy NPR 31-6-10 \\
\hline 347 & Nomenclature Comm., 1945 & Penn, Wolf & Amerada Unit 1 \\
\hline 348 & Nomenclature Comm., 1956 & Penn, Wolf & Gen. Pet. 32-X-21-G \\
\hline 349 & Nomenclature Comm., 1956 & Penn, Wolf & Phillips 2 Cole \\
\hline 350 & Nomenclature Comm., 1956 & Penn, Wolf & Phillips $1 \mathrm{McNeil}$ \\
\hline 351 & Nomenclature Comm., 1956 & Penn, Wolf & Carter 1 Neiman \\
\hline 352 & Agatston, 1954 & Penn, Wolf & La Prol \\
\hline 353 & Agatston, 1954 & Penn, Wolf & Bed Tick Creek \\
\hline 354 & Agatston, 1954 & Penn, Wolf & La Bonte Ranch \\
\hline 355 & Agatston, 1954 & Penn, Wolf & Meeferiene Ranch \\
\hline
\end{tabular}


TABLE 2 (continued)

\begin{tabular}{|c|c|c|c|}
\hline $\begin{array}{l}\text { Section } \\
\text { No. }\end{array}$ & Author & Interval & $\begin{array}{l}\text { Their designation, } \\
\text { section name }\end{array}$ \\
\hline 356 & Agatston, 1954 & Penn, Wolf & Deadhead Basin \\
\hline 357 & Agatston, 1954 & Penn, Wolf & Underwood \\
\hline 358 & Agatston, 1954 & Penn, Wolf & Horse Creek \\
\hline 359 & Agatston, 1954 & Penn, Wolf & Lorenz Ranch \\
\hline 360 & Agatston, 1954 & Penn, Wolf & Granite Canyon \\
\hline 361 & Agatston, 1954 & Penn, Wolf & Cal King \# 1 \\
\hline 362 & Nomenclature Comm., 1956 & Leon III & Ginther Warren and Ginther 1 Fritz \\
\hline 363 & Agatston, 1954 & Penn, Wolf & Ripple Ranch \\
\hline 364 & Mallory, 1967 & Penn, Wolf & 2 \\
\hline 365 & Agatston, 1954 & Penn, Wolf & Telephone Canyon \\
\hline 366 & Mallory, 1967 & Penn, Wolf & 5 \\
\hline 367 & Agatston, 1954 & Penn, Wolf & King Canyon \\
\hline 368 & Mallory, 1967 & Penn, Wolf & 6 \\
\hline 369 & Mallory, 1967 & Penn, Wolf & 7 \\
\hline 370 & Agatston, 1954 & Penn, Wolf & Wheatland Cutoff \\
\hline 371 & Mallory, 1967 & Penn, Wolf & 9 \\
\hline 372 & Mallory, 1967 & Penn, Wolf & 10 \\
\hline 373 & Agatston, 1954 & Penn, Wolf & Gillespie Anticline \\
\hline 374 & Mallory, 1967 & Penn, Wolf & 11 \\
\hline 375 & Agatston, 1954 & Penn, Wolf & Marshall \\
\hline 376 & Mallory, 1967 & Penn & 62 \\
\hline 377 & Agatston, 1954 & Penn, Wolf & Deer Creek \\
\hline 378 & Mallory, 1967 & Penn & 127 \\
\hline 379 & Mallory, 1967 & Penn & 124 \\
\hline 380 & Mallory, 1967 & Penn & 131 \\
\hline 381 & Agatston, 1954 & Penn, Wolf & Pac. West Osborne $\# 1$ \\
\hline 382 & Agatston, 1954 & Penn & Shell-Crow \#1 \\
\hline 383 & Agatston, 1954 & Penn & Warren Montana \\
\hline $384-400$ & $\begin{array}{l}\text { Saperstone and } \\
\text { Ethridge, } 1984\end{array}$ & Penn & $\begin{array}{l}\text { Sections located but data not } \\
\text { given; isopachs in this area } \\
\text { directly from their fig. } 4\end{array}$ \\
\hline
\end{tabular}


TABLE 3

Data base for Jelm Formation

\begin{tabular}{|c|c|c|c|}
\hline $\begin{array}{l}\text { Section } \\
\text { No. }\end{array}$ & Author & Interval & $\begin{array}{l}\text { Their designation, } \\
\text { section name }\end{array}$ \\
\hline 1 & Pipiringos, 1968 & Crow Mountain SS & 5-Lauder \\
\hline 2 & Pipiringos, 1968 & Crow Mountain SS & 6-Dallas Anticline \\
\hline 3 & Pipiringos, 1968 & Crow Mountain SS & 7-Derby Dome \\
\hline 4 & Pipiringos, 1968 & Crow Mountain SS & 9-Sheep Mountain \\
\hline 5 & Pipiringos, 1968 & Crow Mountain SS & 10-Beaver Creek \\
\hline 6 & Pipiringos, 1968 & Crow Mountain SS & 28-Happy Spring \\
\hline 7 & Pipiringos, 1968 & Crow Mountain SS & 30-Green Mountain \\
\hline 8 & Pipiringos, 1968 & Jelm Fm & 31-Ferris Mtn, West \\
\hline 9 & Pipiringos, 1968 & Jelm Fm & 32-Ferris Mtn, East \\
\hline 10 & Pipiringos, 1968 & Jelm Fm & 56-Bell Springs \\
\hline 11 & Pipiringos, 1968 & Jelm Fm & 33-Hurt Creek \\
\hline 12 & Pipiringos, 1968 & Jelm Fm & 35-Sips Creek \\
\hline 13 & Pipiringos, 1968 & Jelm Fm & 37-Troublesome creek \\
\hline 14 & Pipiringos, 1968 & Jelm Fm & 38-Roaring Creek \\
\hline 15 & Pipiringos, 1968 & Jelm Fm & 39-Mud Spring \\
\hline 16 & Pipiringos, 1968 & Jelm Fm & $40-$ Watkins Draw \\
\hline 17 & Pipiringos, 1968 & Jelm Fm & 42-Freezeout Mtns, SW \\
\hline 18 & Pipiringos, 1968 & Jelm Fm & $44-$ Freezeout Mtns, East \\
\hline 19 & Pipiringos and O'Sullivan, 1976 & Triassic-Jurassic & 7-Farthing \\
\hline 20 & Pipiringos and O'Sullivan, 1976 & Triassic-Jurassic & 8-Horse Creek \\
\hline 21 & Pipiringos and O'Sullivan, 1976 & Jelm Fm & 9-Mesa \\
\hline 22 & Pipiringos and O'Sullivan, 1976 & Jelm Fm & 10-Boundary Line \\
\hline 23 & Pipiringos and O'Sullivan, 1976 & Jelm Fm & 11-Sand Creek \\
\hline 24 & Pipiringos and O'Sullivan, 1976 & Jelm Fm & 12-Table Mountain \\
\hline 25 & Pipiringos and O'Sullivan, 1976 & Jelm Fm & 13-Box Elder Creek, north \\
\hline 26 & Pipiringos and O'Sullivan, 1976 & Jelm Fm & 14-Box Elder Creek, south \\
\hline 27 & Pipiringos and O'Sullivan, 1976 & Jelm Fm & 15-Park Creek \\
\hline 28 & Pipiringos and O'Sullivan, 1976 & Jelm Fm & 16-Owl Canyon \\
\hline 29 & Pipiringos and O'Sullivan, 1976 & Jelm Fm & 17-Bellvue \\
\hline 30 & Pipiringos and O'Sullivan, 1976 & Jelm Fm & 19-Loveland \\
\hline 31 & Pipiringos and O'Sullivan, 1976 & Jelm Fm & 20-Dry Creek \\
\hline 32 & Pipiringos and O'Sullivan, 1976 & Jelm Fm & 21 - Little Thompson \\
\hline 33 & Pipiringos and O'Sullivan, 1976 & Triassic-Jurassic & 22-Four Mile Canyon \\
\hline 34 & Pipiringos and O'Sullivan, 1976 & Triassic-Jurassic & 23-Ralston Reservoir \\
\hline 35 & Pipiringos, 1972 & Jelm Fm & 61-Littlefield Creek \\
\hline 36 & Pipiringos, 1972 & Jelm Fm & 62-Space Creek Basin \\
\hline 37 & Pipiringos, 1972 & Jelm Fm & 63-Big Sandstone Creek \\
\hline 38 & Pipiringos, 1972 & Jelm Fm & $65-$ Roaring Fork \\
\hline 39 & Pipiringos, 1972 & Jelm Fm & 96-Hahns Peak \\
\hline 40 & Pipiringos, 1972 & Jelm Fm & 95-Clark \\
\hline 41 & Pipiringos, 1972 & Jelm Fm & 94-Coral Creek \\
\hline 42 & Pipiringos, 1972 & Triassic-Jurassic & 92-King Mountain \\
\hline 43 & Pipiringos, 1972 & Triassic-Jurassic & A-Elk Creek \\
\hline 44 & Pipiringos, 1968 & Jelm & Red Mountain \\
\hline 45 & Craig et al., 1959 & Jelm & 104-Laramie River \\
\hline
\end{tabular}


TABLE 4

Data base for Wingate Sandstone

\begin{tabular}{|c|c|c|c|}
\hline $\begin{array}{l}\text { Section } \\
\text { No. }\end{array}$ & Author & Interval & $\begin{array}{l}\text { Their designation, } \\
\text { section name }\end{array}$ \\
\hline 1 & Phoenix, 1963 & Dinosaur Canyon & Lees Ferry \\
\hline 2 & Wanek and Stevens, 1953 & Dinosaur Canyon & Tanner Wash \\
\hline 3 & Wanek and Stevens, 1953 & Dinosaur Canyon & Tanner Wash \\
\hline 4 & Wanek and Stevens, 1953 & Dinosaur Canyon & Cedar Ridge \\
\hline 5 & Wanek and Stevens, 1953 & Dinosaur Canyon & Cedar Ridge \\
\hline 6 & Wanek and Stevens, 1953 & Dinosaur Canyon & The Gap \\
\hline 7 & Wanek and Stevens, 1953 & Dinosaur Canyon & The Gap \\
\hline 8 & Edwards, 1985 & Dinosaur Canyon & 1 \\
\hline 9 & Edwards, 1985 & Dinosaur Canyon & 2 \\
\hline 10 & Edwards, 1985 & Dinosaur Canyon & 3 \\
\hline 11 & Edwards, 1985 & Dino. Can., Lukachukai & 4 \\
\hline 12 & Edwards, 1985 & Dino. Can., Lukachukai & 5 \\
\hline 13 & Edwards, 1985 & Dino. Can., Lukachukai & 6 \\
\hline 14 & Edwards, 1985 & Dino. Can., Lukachukai & 7 \\
\hline 15 & Edwards, 1985 & Dino. Can., Lukachukai & 8 \\
\hline 16 & Edwards, 1985 & Dino. Can., Lukachukai & 9 \\
\hline 17 & Harshbarger et al., 1957 & Lukachukai & SE Ward Terrace \\
\hline 18 & Edwards, 1985 & Dino. Can., Lukachukai & 13 \\
\hline 19 & Harshbarger et al., 1957 & Lukachukai & Tovar Mesa \\
\hline 20 & Harshbarger et al., 1957 & Dino. Can., Lukachukai & Montezumas Chair \\
\hline 21 & Harshbarger et al., 1957 & Dino. Can., Lukachukai & Navajo Creek \\
\hline 22 & Peterson and Pipiringos, 1979 & Dino. Can., Lukachukai & Square Butte \\
\hline 23 & Imlay, 1980 & Dino. Can., Lukachukai & Cow Springs \\
\hline 24 & Witkind and Thaden, 1963 & Wingate Sandstone & Skeleton Mesa, south \\
\hline 25 & Witkind and Thaden, 1963 & Wingate Sandstone & Skeleton Mesa, north \\
\hline 26 & Witkind and Thaden, 1963 & Wingate Sandstone & Boot Mesa \\
\hline 27 & Witkind and Thaden, 1963 & Wingate Sandstone & Kayenta \\
\hline 28 & Witkind and Thaden, 1963 & Wingate Sandstone & Dinnehotso \\
\hline 29 & Harshbarger et al., 1957 & Wing. SS, Lukachukai Mbr & Rock Point \\
\hline 30 & Harshbarger et al., 1957 & Wing. SS, Lukachukai Mbr & NE of Round Rock \\
\hline 31 & Strobell, 1956 & Wing. SS, Lukachukai Mbr & Lukachukai Mtns. \\
\hline 32 & Stewart et al., 1972 & Wing. SS, Lukachukai Mbr & Many Farms \\
\hline 33 & Harshbarger et al., 1957 & Dino. Can., Lukachukai & Greasewood \\
\hline 34 & Stewart et al., 1972 & Lukachukai Mbr & Lukachukai Trading Post \\
\hline 35 & Stewart et al., 1972 & See comments & Chee Dodge \\
\hline 36 & Stewart et al., 1972 & See comments & Lupton \\
\hline 37 & Strobell, 1956 & Lukachukai Mbr. & Beclabito Dome \\
\hline 38 & Strobell, 1956 & Lukachukai Mbr. & Cont. Oil, Rattlesnake 100 \\
\hline 39 & Stewart et al., 1972 & See comments & Toadalena \\
\hline 40 & Stewart et al., 1972 & See comments & Todilto Park \\
\hline 41 & Stewart et al., 1972 & Dino. Can. Mbr. & Utah Petrified Forest \\
\hline 42 & Blakey, 1970 & Wing. SS, Dino. Can. Mbr & Cockscomb \\
\hline 43 & Blakey, 1970 & Wing. SS, Dino. Can. Mbr & Paria \\
\hline 44 & Stewart, 1972 & Wing. SS, Dino. Can. Mbr & Paria \\
\hline 45 & Imlay, 1980 & Wingate Sandstone & Pine Creek \\
\hline 46 & Imlay, 1980 & Wingate Sandstone & Big Hollow Wash \\
\hline 47 & Davidson, 1967 & Wingate Sandstone & Western Circle Cliffs \\
\hline 48 & Davidson, 1967 & Wingate Sandstone & Eastern Circle Cliffs \\
\hline 49 & Smith et al., 1963 & Wingate Sandstone & Capitol Reef \\
\hline 50 & Peterson (unpubl. data) & Wingate Sandstone & The Block \\
\hline 51 & Peterson (unpubl. data) & Wingate Sandstone & North Wash \\
\hline 52 & Baker, 1946 & Wingate Sandstone & Dirty Devil River \\
\hline
\end{tabular}


TABLE 4 (continued)

\begin{tabular}{|c|c|c|c|}
\hline $\begin{array}{l}\text { Section } \\
\text { No. }\end{array}$ & Author & Interval & $\begin{array}{l}\text { Their designation, } \\
\text { section name }\end{array}$ \\
\hline 53 & Baker, 1946 & Wingate Sandstone & Happy Canyon \\
\hline 54 & Baker, 1946 & Wingate Sandstone & South Trail \\
\hline 55 & Baker, 1946 & Wingate Sandstone & Red Point \\
\hline 56 & Baker, 1946 & Wingate Sandstone & South Block \\
\hline 57 & Baker, 1946 & Wingate Sandstone & Lands End \\
\hline 58 & Baker, 1946 & Wingate Sandstone & North Trail \\
\hline 59 & Baker, 1946 & Wingate Sandstone & Bigwater Canyon \\
\hline 60 & Baker, 1946 & Wingate Sandstone & Horseshoe Canyon \\
\hline 61 & Hawley et al., 1968 & Wingate Sandstone & Tomisich Butte \\
\hline 62 & Hawley et al., 1968 & Wingate Sandstone & Delta Mine \\
\hline 63 & Hawley et al., 1968 & Wingate Sandstone & Temple Mtn. \\
\hline 64 & Baker, 1946 & Wingate Sandstone & Iron Wash \\
\hline 65 & Hawley et al., 1968 & Wingate Sandstone & Straight Wash \\
\hline 66 & Hawley et al., 1968 & Wingate Sandstone & San Rafael Reef \\
\hline 67 & Imlay, 1980 & Wingate Sandstone & Buckhorn Wash \\
\hline 68 & Imlay, 1980 & Wingate Sandstone & Black Dragon Canyon \\
\hline 69 & Dane, 1935 & Wingate Sandstone & Dry Gulch \\
\hline 70 & Imlay, 1980 & Wingate Sandstone & Dewey Bridge \\
\hline 71 & Dane, 1935 & Wingate Sandstone & Big Hole, Westwater Canyon \\
\hline 72 & Dane, 1935 & Wingate Sandstone & Home Oil \#2 \\
\hline 73 & Shawe et al., 1968 & Wingate Sandstone & $\# 1$ \\
\hline 74 & Lewis and Campbell, 1965 & Wingate Sandstone & North of India Creek \\
\hline 75 & Lewis and Campbell, 1965 & Wingate Sandstone & Elk Ridge \\
\hline 76 & Shawe et al., 1968 & Wingate Sandstone & $\# 3$ \\
\hline 77 & Shawe et al., 1968 & Wingate Sandstone & $\# 4$ \\
\hline 78 & Shawe et al., 1968 & Wingate Sandstone & $\# 11$ \\
\hline 79 & Shawe et al., 1968 & Wingate Sandstone & $\# 12$ \\
\hline 80 & Strobell, 1956 & Wingate Sandstone & Western Gas \#1 English \\
\hline 81 & Stewart et al., 1972 & Wingate Sandstone & Poncho House \\
\hline 82 & O'Sullivan, 1965 & Wingate Sandstone & Moses Rock \\
\hline 83 & O'Sullivan, 1965 & Wingate Sandstone & Arizona-Utah line \\
\hline 84 & Baker, 1946 & Wingate Sandstone & Horse Canyon \\
\hline 85 & Baker, 1946 & Wingate Sandstone & West Side Piute Canyon \\
\hline 86 & Baker, 1946 & Wingate Sandstone & Piute Canyon \\
\hline 87 & Baker, 1946 & Wingate Sandstone & North Side No Mans Mesa \\
\hline 88 & Baker, 1946 & Wingate Sandstone & San Juan River at Wilson Creek \\
\hline 89 & Peterson, unpub. & Wingate Sandstone & The Rincon \\
\hline 90 & Mullens, 1960 & Wingate Sandstone & Clay Hills \\
\hline 91 & Thaden et al., 1964 & Wingate Sandstone & North Moss Back \\
\hline 92 & Thaden et al., 1964 & Wingate Sandstone & White Canyon \\
\hline 93 & O’Sullivan, 1965 & Wingate Sandstone & San Juan River \\
\hline 94 & Craig et al., 1959 & Wingate Sandstone & Rifle \\
\hline 95 & Lohman, 1981 & Wingate Sandstone & Colorado National Monument \\
\hline 96 & Craig et al., 1959 & Wingate Sandstone & Ladder Canyon \\
\hline 97 & Craig et al., 1959 & Wingate Sandstone & East Unaweap Canyon \\
\hline 98 & Craig et al:, 1959 & Wingate Sandstone & Tenderfoot Mesa \\
\hline 99 & Imlay, 1980 & Wingate Sandstone & John Brown Canyon \\
\hline 100 & Craig et al., 1959 & Wingate Sandstone & John Brown \\
\hline 101 & Craig et al., 1959 & Wingate Sandstone & North Sinbad Valley \\
\hline 102 & Craig et al., 1959 & Wingate Sandstone & Cashin Mine \\
\hline 103 & Craig et al., 1959 & Wingate Sandstone & Bridgeport \\
\hline 104 & Stewart et al., 1972 & Wingate Sandstone & Bridgeport \\
\hline 105 & Craig et al., 1959 & Wingate Sandstone & N. Fork, Escalante Creek \\
\hline
\end{tabular}


TABLE 4 (continued)

\begin{tabular}{|c|c|c|c|}
\hline $\begin{array}{l}\text { Section } \\
\text { No. }\end{array}$ & Author & Interval & $\begin{array}{l}\text { Their designation, } \\
\text { section name }\end{array}$ \\
\hline 106 & Peterson (unpubl. data) & Wingate Sandstone & Escalante Canyon \\
\hline 107 & Craig et al., 1959 & Wingate Sandstone & Tabequache Canyon \\
\hline 108 & Craig et al., 1959 & Wingate Sandstone & Dry Creek \\
\hline 109 & Shawe et al., 1968 & Wingate Sandstone & $\# 8$ \\
\hline 110 & Bush et al., 1959 & Wingate Sandstone & 4 miles west of Placerville \\
\hline 111 & Shawe et al., 1968 & Wingate Sandstone & D265 \\
\hline 112 & Shawe et al., 1968 & Wingate Sandstone & $\mathrm{D} 270$ \\
\hline 113 & Shawe et al., 1968 & Wingate Sandstone & $\mathrm{M} 230$ \\
\hline 114 & Imlay, 1980 & Wingate Sandstone & Slick Rock \\
\hline 115 & Craig et al., 1959 & Wingate Sandstone & Summit \\
\hline 116 & Shawe et al., 1968 & Wingate Sandstone & $\# 6$ \\
\hline 117 & Shawe et al., 1968 & Wingate Sandstone & $\mathrm{D} 225$ \\
\hline 118 & Shawe et al., 1968 & Wingate Sandstone & OW 250 \\
\hline 119 & Shawe et al., 1968 & Wingate Sandstone & $\# 13$ \\
\hline 120 & Shawe et al., 1968 & Wingate Sandstone & $\# 16$ \\
\hline 121 & Shawe et al., 1968 & Wingate Sandstone & $\# 18$ \\
\hline 122 & Shawe et al., 1968 & Wingate Sandstone & $\# 25$ \\
\hline 123 & Shawe et al., 1968 & Wingate Sandstone & $\# 21$ \\
\hline 124 & Shawe et al., 1968 & Wingate Sandstone & $\# 22$ \\
\hline 125 & Shawe et al., 1968 & Wingate Sandstone & $\# 26$ \\
\hline 126 & Shawe et al., 1968 & Wingate Sandstone & M190 \\
\hline 127 & Shawe et al., 1968 & Wingate Sandstone & M200 \\
\hline 128 & Shawe et al., 1968 & Wingate Sandstone & $\mathrm{M} 200$ \\
\hline 129 & Shawe et al., 1968 & Wingate Sandstone & M194 \\
\hline 130 & Craig et al., 1959 & Wingate Sandstone & Lookout Point \\
\hline 131 & Shawe et al., 1968 & Wingate Sandstone & $\# 14$ \\
\hline 132 & Shawe et al., 1968 & Wingate Sandstone & $\# 15$ \\
\hline 133 & Shawe et al., 1968 & Wingate Sandstone & $\# 23$ \\
\hline 134 & Stewart et al., 1972 & Upper Dolores Formation & Durango \\
\hline 135 & Stewart et al., 1972 & Wingate absent & South Canyon \\
\hline
\end{tabular}


TABLE 5

Data base for Navajo Sandstone and related units

\begin{tabular}{|c|c|c|c|}
\hline $\begin{array}{l}\text { Section } \\
\text { No. }\end{array}$ & Author & Interval & $\begin{array}{l}\text { Their designation, } \\
\text { section name }\end{array}$ \\
\hline 1 & PI & Navajo Sandstone & Arco \#2Dixie \\
\hline 2 & PI & Navajo Sandstone & Chevron \#13-29 Clay Creek \\
\hline 3 & PI & Navajo Sandstone & Hunt \#1 Table Butte \\
\hline 4 & Phoenix, 1963 & Navajo Sandstone & Cedar Mountain \\
\hline 5 & Phoenix, 1963 & Navajo Sandstone & Rawhide Cave \\
\hline 6 & Blakey, 1970 & Navajo Sandstone & Paria River \\
\hline 7 & Wilson, 1965 & Navajo Sandstone & 2-Zion Canyon \\
\hline 8 & Wilson, 1965 & Navajo Sandstone & $3-$ Kanab \\
\hline 9 & Harshbarger et al., 1957 & Navajo Sandstone & 6-Dinnehotso \\
\hline 10 & Harshbarger et al., 1957 & Navajo Sandstone & 1-Rech Point Trading Post \\
\hline 11 & Harshbarger et al., 1957 (A) & Navajo Sandstone & Monitor Mesa \\
\hline 12 & Harshbarger et al., 1957 (A) & Navajo Sandstone & Kayenta \\
\hline 13 & Harshbarger et al., 1957 (A) & Navajo Sandstone & Betatakin Ruin \\
\hline 14 & Harshbarger et al., 1957 (A) & Navajo Sandstone & Navajo Creek \\
\hline 15 & Harshbarger et al., 1957 (A) & Navajo Sandstone & Gap \\
\hline 16 & Harshbarger et al., 1957 (A) & Navajo Sandstone & Moenave \\
\hline 17 & Harshbarger et al., 1957 (A) & Navajo Sandstone & Dinosaur Canyon \\
\hline 18 & Harshbarger et al., 1957 (A) & Navajo Sandstone & Kachina Point \\
\hline 19 & Harshbarger et al., 1957 (A) & Navajo Sandstone & Yale Point \\
\hline 20 & O'Sullivan, 1965 & Navajo Sandstone & Chinle Wash \\
\hline 21 & Strobell, 1956 & Navajo Sandstone & A-Boundary Butte \\
\hline 22 & Strobell, 1956 & Navajo Sandstone & 9-Toh Acon Mesa \\
\hline 23 & Strobell, 1956 & Navajo Sandstone & 10-Kinusta Mesa \\
\hline 24 & Strobell, 1956 & Navajo Sandstone & 6-Cove Mesa \\
\hline 25 & Strobell, 1956 & Navajo Sandstone & Regional estimate \\
\hline 26 & Peterson (unpubl. data) & Navajo Sandstone & 123-Second Mesa \\
\hline 27 & Peterson (unpubl. data) & Navajo Sandstone & 1100 -North Wash \\
\hline 28 & Smith et al., 1963 & Navajo Sandstone & Boulder Mtn. UT \\
\hline 29 & Smith et al., 1963 & Navajo Sandstone & Waterpocket fold, UT \\
\hline 30 & Thaden et al., 1964 & Navajo Sandstone & Red Canyon, UT \\
\hline 31 & Davidson, 1967 & Navajo Sandstone & 12-E. Cent. Circle Cliffs \\
\hline 32 & Davidson, 1967 & Navajo Sandstone & Grand Gulch \\
\hline 33 & Davidson, 1967 & Navajo Sandstone & Regional estimate \\
\hline 34 & Beaumont and Dixon, 1964 & Navajo Sandstone & 8-Marsh Pass AZ \\
\hline 35 & Beaumont and Dixon, 1964 & Navajo Sandstone & 13-Kayenta AZ \\
\hline 36 & O’Sullivan and Green, 1973 & Navajo Sandstone & Round Point, AZ \\
\hline 37 & O'Sullivan and Green, 1973 (A) & Navajo Sandstone & 2-Bluff, UT \\
\hline 38 & O'Sullivan and Green, 1973 (A) & Navajo Sandstone & 1-Comb Ridge, UT \\
\hline 39 & Hunt et al., 1953 & Navajo Sandstone & Muddy River \\
\hline 40 & Hunt et al., 1953 & Navajo Sandstone & Burr Trail \\
\hline 41 & Hunt et al., 1953 & Navajo Sandstone & Angel Cove \\
\hline 42 & Gregory, 1938 & Navajo Sandstone & South side Wilson Mesa \\
\hline 43 & F. Peterson (unpubl. data) & Navajo Sandstone & 1196-Uravan, CO \\
\hline 44 & Craig et al., 1959 & Navajo Sandstone & 35-Cashin Mine, CO \\
\hline 45 & Craig et al., 1955 & Navajo Sandstone & 58-Dove Spring, CO \\
\hline 46 & Craig et al., 1959 & Navajo Sandstone & 87-Hamm Spring, CO \\
\hline 47 & Craig et al., 1959 & Navajo Sandstone & 99-Horseshoe Groupo, CO \\
\hline 48 & Craig et al., 1959 & Navajo Sandstone & 101 -John Brown Canyon, CO \\
\hline 49 & Craig et al., 1959 & Navajo Sandstone & 120-Lookout Point, CO \\
\hline 50 & Craig et al., 1959 & Navajo Sandstone & 136-Maverick Canyon, CO \\
\hline 51 & Craig et al., 1959 & Navajo Sandstone & 150-N. Sinbad Valley, CO \\
\hline 52 & Craig et al., 1959 & Navajo Sandstone & 200 -Summit Point, CO \\
\hline 53 & Craig et al., 1959 & Navajo Sandstone & 220-Vermillion Creek, CO \\
\hline
\end{tabular}


TABLE 5 (continued)

\begin{tabular}{|c|c|c|c|}
\hline $\begin{array}{l}\text { Section } \\
\text { No. }\end{array}$ & Author & Interval & $\begin{array}{l}\text { Their designation, } \\
\text { section name }\end{array}$ \\
\hline 54 & Craig et al., 1959 & Navajo Sandstone & 226-Wild Bill Canyon, CO \\
\hline 55 & Shawe et al., 1968 & Navajo Sandstone & 3-White Cany. Mining Co, UT Frost $\# 1$ \\
\hline 56 & Shawe et al., 1968 & Navajo Sandstone & 4-Western Natural Gas, UT Redd 1 \\
\hline 57 & Shawe et al., 1968 & Navajo Sandstone & 11-Gulf Oil Corp, UT Coalbed Cany. 1 \\
\hline 58 & Shawe et al., 1968 & Navajo Sandstone & 12 Gulf Oil Corp, UT Coalbed Cany. 2 \\
\hline \multirow[t]{2}{*}{59} & Craig et al., 1959 & Navajo Sandstone & 13 - Continental Oil $\mathrm{Co}, \mathrm{CO}$ \\
\hline & & & Baumgartner-Sane 1 \\
\hline 60 & Shawe et al., 1968 & Navajo Sandstone & 18-Hathaway Co, CO Lyon-Federal 1 \\
\hline 61 & Shawe et al., 1968 & Navajo Sandstone & $\begin{array}{l}\text { 17-Three States Natural Gas White } \\
\# 1, \mathrm{CO}\end{array}$ \\
\hline 62 & Shawe et al., 1968 & Navajo Sandstone & 19-Byrd--Frost J.W. White \#1 \\
\hline 63 & Shawe et al., 1968 & Navajo Sandstone & 20-Byrd-Frost Driscoll 1, CO \\
\hline 64 & Shawe et al., 1968 & Navajo Sandstone & 26-Gulf Oil Corp, Fulks 1, CO \\
\hline 65 & Shawe et al., 1968 & Navajo Sandstone & 22-HER Drill. Co., CO Lane-Coffee 1A \\
\hline 66 & Shawe et al., 1968 & Navajo Sandstone & 23-Continental Oil Co, Lone Dome 1, CO \\
\hline 67 & Shawe et al., 1968 & Navajo Sandstone & 15-Moody Oil Corp, CO Stathepulous 1 \\
\hline 68 & Shawe et al., 1968 & Navajo Sandstone & 14-Byrd-Frost J.A. Uhl-Govt. 1, CO \\
\hline 69 & Shawe et al., 1968 & Navajo Sandstone & 10 -Carter Oil Co., Glade 1, CO \\
\hline 70 & Shawe et al., 1968 & Navajo Sandstone & 5-Prestidge-Allison Long 1, CO \\
\hline 71 & Shawe et al., 1968 & Navajo Sandstone & 6-Reynolds Mining Co, Egnar 1, CO \\
\hline 72 & Shawe et al., 1968 & Navajo Sandstone & 8 - Fred Turner Bues $1, \mathrm{CO}$ \\
\hline 73 & Shawe et al., 1968 & Navajo Sandstone & $\mathrm{M} 40,43 \mathrm{~N}, 19 \mathrm{~W}, \mathrm{CO}$ \\
\hline 74 & Shawe et al., 1968 & Navajo Sandstone & $\mathrm{M} 12,42 \mathrm{~N}, 18 \mathrm{~W}, \mathrm{CO}$ \\
\hline 75 & Shawe et al., 1968 & Navajo Sandstone & 1--Temple Mtn, UT \\
\hline 76 & Shawe et al., 1968 & Navajo Sandstone & 3-Bear Ears, UT \\
\hline 77 & Shawe et al., 1968 & Navajo Sandstone & 4--Horse Flats, UT \\
\hline 78 & Shawe et al., 1968 & Navajo Sandstone & 5-Abajo Mtns, UT \\
\hline 79 & Shawe et al., 1968 & Navajo Sandstone & 6-Bridger Jack Mesa, UT \\
\hline 80 & Shawe et al., 1968 & Navajo Sandstone & 7 - North Sixshooter Peak, UT \\
\hline 81 & Shawe et al., 1968 & Navajo Sandstone & 8-Lockhart Basin, UT \\
\hline 82 & Shawe et al., 1968 & Navajo Sandstone & $9-$ Moab, UT \\
\hline 83 & Shawe et al., 1968 & Navajo Sandstone & 10 -Sevenmile Canyon, UT \\
\hline 84 & Hamilton, 1978 & Navajo Sandstone & Horse Ranch Mtn, UT \\
\hline 85 & Hamilton, 1978 & Navajo Sandstone & Wynopits Mtn, UT \\
\hline 86 & Baker et al., 1936 & Navajo Sandstone & 77-Tuba City, AZ \\
\hline 87 & Baker et al., 1936 & Navajo Sandstone & $50-$ Navajo Mtn, UT \\
\hline 88 & Baker et al., 1936 & Navajo Sandstone & 14 - Circle Cliffs, UT \\
\hline 89 & Baker et al., 1936 & Navajo Sandstone & 68-Saddle Horse Canyon, UT \\
\hline 90 & Baker et al., 1936 & Glen Canyon SS. & 22-Dinosaur Quarry, UT \\
\hline 91 & Baker et al., 1936 & Glen Canyon SS. & 29-Flaming Gorge, UT \\
\hline 92 & Baker et al., 1936 & Navajo Sandstone & 23-Diamond Valley, UT \\
\hline 93 & Baker et al., 1936 & Navajo Sandstone & 54-Paria River, UT \\
\hline 94 & Baker et al., 1936 & Navajo Sandstone & 33-Green River Desert, UT \\
\hline 95 & Baker et al., 1936 & Navajo Sandstone & $37-$ Indian Creek, UT \\
\hline 96 & Baker et al., 1936 & Navajo Sandstone & 4-Black Dragon Canyon, UT \\
\hline 97 & Baker et al., 1936 & Navajo Sandstone & 75-Salt Valley Canyon, UT \\
\hline 98 & Baker et al., 1936 & Navajo Sandstone & 20-Dewey, UT \\
\hline 99 & Baker et al., 1936 & Navajo Sandstone & 67-Schart Ranch, UT \\
\hline 100 & Knapp, 1976 & Nugget Sandstone & Vermillion Creek, CO \\
\hline 101 & Knapp, 1976 & Nugget Sandstone & Farm Creek, UT \\
\hline 102 & Knapp, 1976 & Nugget Sandstone & Split Mtn, UT \\
\hline 103 & Pacht, 1976 & Nugget Sandstone & Mahagony Hills, UT \\
\hline 104 & Hewett, 1956 & Aztec Sandstone & $2 \mathrm{mi} \mathrm{W}$ of Kokoweef Peak CA \\
\hline 105 & Hewett, 1931 (A) & Aztec Sandstone & N. boundary Goodsprings Quad, N.M. \\
\hline
\end{tabular}


TABLE 5 (continued)

\begin{tabular}{|c|c|c|c|}
\hline $\begin{array}{l}\text { Section } \\
\text { No. }\end{array}$ & Author & Interval & $\begin{array}{l}\text { Their designation, } \\
\text { section name }\end{array}$ \\
\hline 106 & Porter, 1985 & Aztec Sandstone & N. Old Dad Mtn, CA \\
\hline 107 & Porter, 1985 & Aztec Sandstone & S. Old Dad Mtn, CA \\
\hline 108 & Porter, 1985 & Aztec Sandstone & Notch Draw, Mescal Range, CA \\
\hline 109 & Porter, 1985 & Aztec Sandstone & Spring Ranch, NV \\
\hline 110 & Porter, 1985 & Aztec Sandstone & Visitor Center, Valley of Fire, NV \\
\hline 111 & Longwell, 1928 & Aztec Sandstone & $3 \mathrm{mi} \mathrm{W}$. Logandale NV \\
\hline 112 & PI & Navajo Sandstone & 1 Hopi-9, AZ \\
\hline 113 & Uggur, 1980 & Navajo Sandstone & 465 \\
\hline 114 & Uggur, 1980 & Navajo Sandstone & 423 \\
\hline 115 & Uggur, 1980 & Navajo Sandstone & 430 \\
\hline 116 & Uggur, 1980 & Navajo Sandstone & 350 \\
\hline 117 & Uggur, 1980 & Navajo Sandstone & 370 \\
\hline 118 & PI & Nugget Sandstone & Mtn. Fuel Supply Co. Canyon Cr \#17 \\
\hline 119 & PI & Nugget Sandstone & Pan American Jim Springs \#7 \\
\hline 120 & PI & Nugget Sandstone & Exxon Red Creek \#1 \\
\hline 121 & PI & Nugget Sandstone & Devon Joyce Ck \#11-8 \\
\hline 122 & PI & Nugget Sandstone & Mtn. Fuel S. Baxter \#1 \\
\hline 123 & PI & Nugget Sandstone & Mtn. Fuel S. Baxter \#15 \\
\hline 124 & PI & Nugget Sandstone & Champlin Petroleum Brady \#1 \\
\hline 125 & PI & Nugget Sandstone & Red Desert Edith Aspden \#1 \\
\hline 126 & PI & Nugget Sandstone & Mtn. Fuel Agnes Fay \#1 \\
\hline 127 & PI & Nugget Sandstone & Mtn. Fuel Hetzler \#2 \\
\hline 128 & PI & Nugget Sandstone & Pongratz Gas Clark \#1 \\
\hline 129 & PI & Nugget Sandstone & Mtn. Fuel UPRR \# 3 \\
\hline 130 & PI & Nugget Sandstone & Mtn. Fuel UPRR \#2 \\
\hline 131 & PI & Nugget Sandstone & Cities Service UPRR \#1 \\
\hline 132 & PI & Nugget Sandstone & Barnes Federal \# 5-11 \\
\hline 133 & PI & Nugget Sandstone & Mtn. Fuel Church Buttes \#2 \\
\hline 134 & PI & Nugget Sandstone & Mtn. Fuel Church Buttes \#19 \\
\hline 135 & PI & Nugget Sandstone & Mtn. Fuel Bruff \# 1 \\
\hline 136 & PI & Nugget Sandstone & Mtn. Fuel \\
\hline 137 & PI & Nugget Sandstone & Helis Estate E. Sulphur Creek \\
\hline 138 & PI & Nugget Sandstone & Brinkerhoff Piedmont 1-31 \\
\hline 139 & PI & Nugget Sandstone & Shell Leroy Unit 1-4295 \\
\hline 140 & PI & Nugget Sandstone & Helis Estate Bridger State 3-1 \\
\hline 141 & PI & Nugget Sandstone & Arrowhead Scully Gap Gut. 1 \\
\hline 142 & PI & Nugget Sandstone & Cal. Oil VP-1, Muddy Creek \\
\hline 143 & PI & Nugget Sandstone & Marathon Albert Creek-1 \\
\hline 144 & PI & Nugget Sandstone & Belco Hams Fork 30-2 \\
\hline 145 & PI & Nugget Sandstone & Quad States Cumberland \\
\hline 146 & PI & Nugget Sandstone & Conoco Hams Fork 23-1 \\
\hline 147 & PI & Nugget Sandstone & Union Carter \\
\hline 148 & Asquith (pers. commun.) & Nugget Sandstone & Jackson Creek \\
\hline 149 & PI & Nugget Sandstone & Brack Drilling Co. Fontonelle \#2 \\
\hline 150 & Asquith (pers. commun.) & Nugget Sandstone & Fontonelle Creek \\
\hline 151 & PI & Nugget Sandstone & Phillips Co. Fort A\# 1 \\
\hline 152 & PI & Nugget Sandstone & Carter Oil Meridian Ridge \\
\hline 153 & Asquith (pers. commun.) & Nugget Sandstone & La Barge Creek \\
\hline 154 & Furer (pers. commun.) & Nugget Sandstone & Rock Creek \\
\hline 155 & PI & Nugget Sandstone & Mtn. Fuel Dry Piney \#24 \\
\hline 156 & PI & Nugget Sandstone & Mobil Oil Tip Top \# 83-11 \\
\hline 157 & PI & Nugget Sandstone & Exxon Hobada II Unit \#2 \\
\hline
\end{tabular}


TABLE 5 (continued)

\begin{tabular}{|c|c|c|c|}
\hline $\begin{array}{l}\text { Section } \\
\text { No. }\end{array}$ & Author & Interval & $\begin{array}{l}\text { Their designation, } \\
\text { section name }\end{array}$ \\
\hline 158 & PI & Nugget Sandstone & General Petroleum Lake Ridge \#43-19 \\
\hline 159 & PI & Nugget Sandstone & California Oil Tierney \#1 \\
\hline 160 & Bragdon, 1965 & Nugget Sandstone & E. Fork Greys River \\
\hline 161 & Asquith (pers. commun.) & Nugget Sandstone & North Darby \\
\hline 162 & PI & Nugget Sandstone & Phillips Oil Hoback A \#1 \\
\hline 163 & Wanless et al., 1955 & Nugget Sandstone & Fall Creek \\
\hline 164 & Froidenaux, 1968 & Nugget Sandstone & Claus Peak \\
\hline 165 & Thompson (pers. commun.) & Nugget Sandstone & Hoback Peak \\
\hline 166 & Wanless et al., 1955 & Nugget Sandstone & Hoback Mtn. \\
\hline 167 & Wanless et al., 1955 & Nugget Sandstone & Dell Creek \\
\hline 168 & Wanless et al., 1955 & Nugget Sandstone & Moose Creek \\
\hline 169 & Wanless et al., 1955 & Nugget Sandstone & Gros Ventre Canyon \\
\hline 170 & Foster 1947 & Nugget Sandstone & Ditch Creek \\
\hline 171 & PI & Nugget Sandstone & Tennessee Gas Transmission Sohare \#2 \\
\hline 172 & PI & Nugget Sandstone & True Oil Kirkwood-Federal \#11-23 \\
\hline 173 & Love et al., 1945 & Nugget Sandstone & 1 -Horse Creek \\
\hline 174 & PI & Nugget Sandstone & Shell Oil Goose Lake \#1 \\
\hline 175 & Love et al., 1945 & Nugget Sandstone & 2--Duncan P.O. \\
\hline 176 & Love et al., 1945 & Nugget Sandstone & 2N Ranch \\
\hline 177 & PI & Nugget Sandstone & Carter Oil \#1 State \\
\hline 178 & Richmond 1985 & Nugget Sandstone & Green River Lakes \\
\hline 179 & Love et al., 1945 & Nugget Sandstone & 3 - Red Grade \\
\hline 180 & Love et al., 1945 & Nugget Sandstone & 4-Red Creek \\
\hline 181 & Love et al., 1945 & Nugget Sandstone & 5-Maverick Springs \\
\hline 182 & PI & Nugget Sandstone & British American Tribal \#C-3 \\
\hline 183 & PI & Nugget Sandstone & British American Tribal \#A-1 \\
\hline 184 & PI & Nugget Sandstone & Stanolind Oil and Gas Tribal \#1 \\
\hline 185 & Love et al., 1945 & Nugget Sandstone & 29-Sage $\dot{C} k$ Anticline \\
\hline 186 & Love et al., 1945 & Nugget Sandstone & 13-Crooked Creek \\
\hline 187 & Love et al., 1945 & Nugget Sandstone & 15-Lander Anticline \\
\hline 188 & Love et al., 1945 & Nugget Sandstone & 16-Squaw Creek \\
\hline 189 & Love et al., 1945 & Nugget Sandstone & 17 -Dallas Anticline \\
\hline 190 & Love et al, 1945 & Nugget Sandstone & Derby Anticline \\
\hline 191 & PI & Nugget Sandstone & Phillips Horseshoe Creek \#1 \\
\hline 192 & Espach and Royse 1960 & Nugget Sandstone & E. Big Hole Mtns. \\
\hline 193 & Wanless et al., 1955 & Nugget Sandstone & Snake River \\
\hline 194 & $\begin{array}{l}\text { Williams and Kraetsch } \\
\text { (pers. commun.) }\end{array}$ & Nugget Sandstone & Teton Basin \\
\hline 195 & $\begin{array}{l}\text { Wyman and Newcomb } \\
\text { (pers. commun.) }\end{array}$ & Nugget Sandstone & North Snake \\
\hline 196 & Chevron (unpubl. data) & Nugget Sandstone & Bonneville \\
\hline 197 & Chevron (unpubl. data) & Nugget Sandstone & Garden Creek \\
\hline 198 & Chevron (unpubl. data) & Nugget Sandstone & Pritchard Creek \\
\hline 199 & Asquith (pers. commun.) & Nugget Sandstone & Bailey Lake \\
\hline 200 & Mansfield 1927 & Nugget Sandstone & Fort Hall \\
\hline 201 & Asquith (pers. commun.) & Nugget Sandstone & Barley Lake \\
\hline 202 & Asquith (pers. commun.) & Nugget Sandstone & True Oil Greys River \#44-25 \\
\hline 203 & Asquith (pers. commun.) & Nugget Sandstone & Blind Bull Creek \\
\hline 204 & Wolf (pers. commun.) & Nugget Sandstone & Swift Creek \\
\hline 205 & Mansfield, 1927 & Nugget Sandstone & Freedom quad. \\
\hline 206 & Cressman, 1964 & Nugget Sandstone & Preuss Creek \\
\hline 207 & Cressman, 1964 & Nugget Sandstone & Dunns Canyon \\
\hline
\end{tabular}


TABLE 5 (continued)

\begin{tabular}{|c|c|c|c|}
\hline $\begin{array}{l}\text { Section } \\
\text { No. }\end{array}$ & Author & Interval & $\begin{array}{l}\text { Their designation, } \\
\text { section name }\end{array}$ \\
\hline 208 & Asquith (pers. commun.) & Nugget Sandstone & S. LaBarge Creek \\
\hline 209 & Asquith (pers. commun.) & Nugget Sandstone & Allen Creek \\
\hline 210 & Asquith (pers. commun.) & Nugget Sandstone & Hams Fork \\
\hline 211 & Asquith (pers. commun.) & Nugget Sandstone & Fontonelle Creek \\
\hline 212 & Asquith (pers. commun.) & Nugget Sandstone & Pine Creek \\
\hline 213 & Asquith (pers. commun.) & Nugget Sandstone & Cokeville Butte \\
\hline 214 & Asquith (pers. commun.) & Nugget Sandstone & Trail Creek \\
\hline 215 & Chevron (unpub. data) & Nugget Sandstone & Sheep Creek \\
\hline 216 & Asquith (pers. commun.) & Nugget Sandstone & Rock Creek Ridge \\
\hline 217 & Asquith (pers. commun.) & Nugget Sandstone & Miller Canyon \\
\hline 218 & PI & Nugget Sandstone & Amoco Ryckman Ck \#224 \\
\hline 219 & Richardson, 1941 & Nugget Sandstone & Randolph quad. \\
\hline 220 & Eardley, 1944 & Nugget Sandstone & Weber Canyon \\
\hline 221 & PI & Nugget Sandstone & American Quasar Pineview \\
\hline 222 & Morris, 1953 & Nugget Sandstone & Weber River \\
\hline 223 & Granger, 1953 & Nugget Sandstone & Parleys Canyon \\
\hline 224 & Stokes, 1959 & Nugget Sandstone & Toone Canyon \\
\hline 225 & Thomas and Krueger, 1946 & Nugget Sandstone & Mahogany Hills \\
\hline 226 & Asquith (pers. commun.) & Nugget Sandstone & Pullem Creek \\
\hline 227 & Baker et al., 1936 & Nugget Sandstone & Scott's Draw \\
\hline 228 & PI & Nugget Sandstone & Phillips Fork $A \# 10$ \\
\hline 229 & Thomas and Krueger, 1945 & Nugget Sandstone & Duchesne River \\
\hline 230 & Thomas and Krueger, 1945 & Nugget Sandstone & Lake Fork \\
\hline 231 & Thomas and Krueger, 1945 & Nugget Sandstone & Whiterocks \\
\hline 232 & PI & Nugget Sandstone & Cotten Petroleum Bruchez \#1 \\
\hline 233 & PI & Nugget Sandstone & Basin Petroleum Riley-Federal \#1-29 \\
\hline 234 & PI & Nugget Sandstone & Arco \#1 Maeser-Federal \\
\hline 235 & PI & Nugget Sandstone & Conoco McKonkie \#1 \\
\hline 236 & Thomas et al., 1945 & Nugget Sandstone & Vernal \\
\hline 237 & PI & Nugget Sandstone & Promontory Oil Buckskin Hill \\
\hline 238 & PI & Nugget Sandstone & Flying Diamond \# 1 N. Ashley-State \\
\hline 239 & PI & Nugget Sandstone & Dunlap D.P. Federal \# 1 \\
\hline 240 & PI & Nugget Sandstone & Dimension Oil and Gas \#1 \\
\hline 241 & PI & Nugget Sandstone & Sunray Ox Oil Ceceil R. Rupple \# 1 \\
\hline 242 & PI & Nugget Sandstone & Equity Oil Ashley Valley \\
\hline 243 & PI & Nugget Sandstone & Moore Govt. \# 1 \\
\hline 244 & Chevron (unpubl. data) & Nugget Sandstone & Dinosaur quarry \\
\hline 245 & Thomas et al., 1945 & Nugget Sandstone & Split Mountain \\
\hline 246 & Chevron (unpubl. data) & Nugget Sandstone & Island Park \\
\hline 247 & PI & Nugget Sandstone & Hiko Bell Federal \#1 \\
\hline 248 & Hansen, 1965 & Nugget Sandstone & Manila \\
\hline 249 & Hansen, 1965 & Nugget Sandstone & Horseshoe Canyon \\
\hline 250 & PI & Nugget Sandstone & Ohio Oil Co. Brush Creek \#1 \\
\hline 251 & PI & Nugget Sandstone & Mtn. Fuel Supply Co. Clay Basin \\
\hline 252 & PI & Nugget Sandstone & Texaco \#3 Van-Schailk \\
\hline 253 & PI & Nugget Sandstone & Mtn. Fuel Supply Co. Irish Cany. \# 1 \\
\hline 254 & PI & Nugget Sandstone & Hanson Oil Co. \#1-AX Moroni \\
\hline 255 & Pacht, 1976 & Nugget Sandstone & La Barge Creek \\
\hline 256 & Pacht, 1976 & Nugget Sandstone & Gros Ventre River \\
\hline 257 & Pacht, 1976 & Nugget Sandstone & Du Bois \\
\hline 258 & Keefer, 1957 & Nugget Sandstone & Sinclair Wyo. DuBois Well \#1 \\
\hline 259 & Love et al., 1942 & Nugget Sandstone & Horse Creek \\
\hline 260 & Keefer, 1957 & Nugget Sandstone & Sinclair Wyo. DuBois Well \#2 \\
\hline
\end{tabular}


TABLE 5 (continued)

\begin{tabular}{|c|c|c|c|}
\hline $\begin{array}{l}\text { Section } \\
\text { No. }\end{array}$ & Author & Interval & $\begin{array}{l}\text { Their designation, } \\
\text { section name }\end{array}$ \\
\hline 261 & Love, 1957 & Nugget Sandstone & Tribal Well \#1 \\
\hline 262 & Love, 1957 & Nugget Sandstone & Tribal Well B2 \\
\hline 263 & Love, 1957 & Nugget Sandstone & Shoshone-Arapahoe 1 \\
\hline 264 & Love, 1957 & Nugget Sandstone & Tribal \#1 \\
\hline 265 & Love, 1957 & Nugget Sandstone & Baldwin Creek \\
\hline 266 & Love, 1957 & Nugget Sandstone & Squaw Creek \\
\hline 267 & Pacht, 1976 & Nugget Sandstone & Lander \\
\hline 268 & Pipiringos, 1968 & Nugget Sandstone & Dallas Anticline \\
\hline 269 & Pipiringos, 1968 & Nugget Sandstone & Derby Dome \\
\hline 270 & Pipiringos, 1968 & Nugget Sandstone & Johnson Ranch \\
\hline 271 & Pipiringos, 1968 & Nugget Sandstone & Sheep Mountain \\
\hline 273 & Knapp, 1976 & Nugget Sandstone & Lander \\
\hline 274 & Pipiringos, 1968 & Nugget Sandstone & Happy Spring \\
\hline 275 & Pipiringos, 1968 & Nugget Sandstone & Green Mountain \\
\hline 276 & Pipiringos, 1968 & Nugget Sandstone & Ferris Mountains \\
\hline 277 & Love, 1957 & Nugget Sandstone & Beaver Creek \\
\hline 278 & Love, 1957 & Nugget Sandstone & Embar \#14 \\
\hline 279 & Love, 1957 & Nugget Sandstone & Heaney \#1 \\
\hline 280 & Love, 1957 & Nugget Sandstone & Emigrant Trail \#1 \\
\hline 281 & Love, 1957 & Nugget Sandstone & Happy Springs Unit $\# 23$ \\
\hline 282 & Love, 1957 & Nugget Sandstone & Crooks Gap \#10 \\
\hline 283 & Love, 1957 & Nugget Sandstone & Werty $E-31$ \\
\hline 284 & Love, 1957 & Nugget sandstone & Bailey \#3 \\
\hline 285 & Love, 1957 & Nugget Sandstone & Hintze \#1 \\
\hline 286 & Love, 1957 & Nugget Sandstone & $\mathrm{C}-\mathrm{F}-7$ \\
\hline 287 & Love, 1957 & Nugget Sandstone & $2 S-7$ \\
\hline 288 & Averitt, 1962 & Navajo Sandstone & Sugarloaf Mountain \\
\hline 289 & Weaver, 1980 & Navajo Sandstone & Blue Mountain \\
\hline 290 & George, 1985 & Navajo Sandstone & Pavant Range \\
\hline 291 & Harshbarger et al., 1957 & Navajo Sandstone & Navajo Point \\
\hline 292 & Harshbarger et al., 1957 & Nugget Sandstone & Square Butte \\
\hline 293 & Harshbarger et al., 1957 & Navajo Sandstone & Coal Canyon \\
\hline 294 & Harshbarger et al., 1957 & Navajo Sandstone & Bound Rock \\
\hline 295 & Harshbarger et al., 1957 & Navajo Sandstone & Mexican Water \\
\hline 296 & PI & Navajo Sandstone & Three Peaks No. 1 \\
\hline 297 & Harshbarger et al., 1957 & Navajo Sandstone & Many Farms \\
\hline 298 & Bilodeau and Keith, 1986 & Sil Nakya Formation & Sil Nakya Hills \\
\hline 299 & Bilodeau and Keith, 1986 & Ali Molina Formation & Baboquivari Mountains \\
\hline 300 & Bilodeau and Keith, 1986 & Ox Frame Volcanics & Sierrita Mountains \\
\hline 301 & Bilodeau and Keith, 1986 & Mt. Wrightson Form. & Santa Rita Mountains \\
\hline 302 & Miller and Carr, 1978 & Metaquartzite & Rodman Mountains \\
\hline 303 & Marzolf, 1983 & Aztec Sandstone & Soda Mountains \\
\hline 304 & Thomas et al., 1945 & & Meeker Dome \\
\hline
\end{tabular}


TABLE 6

Data base for Temple Cap Sandstone, Romana Sandstone, and Morrison-age eolian deposits

\begin{tabular}{|c|c|c|c|}
\hline $\begin{array}{l}\text { Section } \\
\text { No. }\end{array}$ & Author & Interval & $\begin{array}{l}\text { Their designation, } \\
\text { section name }\end{array}$ \\
\hline 1 & Lupe, $1983(\mathrm{P})$ & Bluff Sandstone & 308 \\
\hline 2 & Lupe, 1983 (P) & Bluff Sandstone & 310 \\
\hline 3 & Lupe, $1983(\mathrm{P})$ & Bluff Sandstone & 133 \\
\hline 4 & Lupe, 1983 (P) & Bluff Sandstone & 321 \\
\hline 5 & Lupe, $1983(\mathrm{P})$ & Bluff Sandstone & 320 \\
\hline 6 & Lupe, $1983(\mathrm{P})$ & Bluff Sandstone & 315 \\
\hline 7 & Lupe, $1983(P)$ & Bluff Sandstone & 56 \\
\hline 8 & Lupe, 1983 (P) & Bluff Sandstone & 212 \\
\hline 9 & Lupe, $1983(\mathrm{P})$ & Bluff Sandstone & 91 \\
\hline 10 & Lupe, $1983(\mathrm{P})$ & Bluff Sandstone & 89 \\
\hline 11 & Lupe, $1983(\mathrm{P})$ & Bluff Sandstone & 97 \\
\hline 12 & Lupe, 1983 (P) & Junction Creek Sandstone & 268 \\
\hline 13 & Lupe, 1983 (P) & Junction Creek Sandstone & 278 \\
\hline 14 & Lupe, $1983(\mathrm{P})$ & Junction Creek Sandstone & 283 \\
\hline 15 & Lupe, 1983 (P) & Junction Creek Sandstone & 288 \\
\hline 16 & Lupe, 1983 (P) & Junction Creek Sandstone & 287 \\
\hline 17 & Lupe, 1983 (P) & Junction Creek Sandstone & 132 \\
\hline 18 & Lupe, 1983 (P) & Junction Creek Sandstone & 49 \\
\hline 19 & Lupe, 1983 (P) & Junction Creek Sandstone & 85 \\
\hline 20 & Lupe, $1983(\mathrm{P})$ & Junction Creek Sandstone & 94 \\
\hline 21 & Lupe, $1983(\mathrm{P})$ & Junction Creek Sandstone & 252 \\
\hline 22 & Lupe, 1983 (P) & Junction Creek Sandstone & 247 \\
\hline 23 & Lupe, 1983 (P) & Junction Creek Sandstone & 112 \\
\hline 24 & Lupe, $1983(\mathrm{P})$ & Junction Creek Sandstone & 286 \\
\hline 25 & Lupe, $1983(\mathrm{P})$ & Junction Creek Sandstone & 285 \\
\hline 26 & Lupe, $1983(\mathrm{P})$ & Junction Creek Sandstone & 122 \\
\hline 27 & Lupe, $1983(\mathrm{P})$ & Junction Creek Sandstone & 292 \\
\hline 28 & Lupe, $1983(\mathrm{P})$ & Junction Creek Sandstone & 46 \\
\hline 29 & Lupe, $1983(\mathrm{P})$ & Junction Creek Sandstone & 83 \\
\hline 30 & Lupe, 1983 (P) & Junction Creek Sandstone & 272 \\
\hline 31 & Lupe, $1983(P)$ & Junction Creek Sandstone & 156 \\
\hline 32 & Lupe, 1983 (P) & Junction Creek Sandstone & 162 \\
\hline 33 & Lupe, $1983(\mathrm{P})$ & Junction Creek Sandstone & 177 \\
\hline 34 & Lupe, 1983 (P) & Junction Creek Sandstone & 22 \\
\hline 35 & Lupe, $1983(\mathrm{P})$ & Junction Creek Sandstone & 190 \\
\hline 36 & Lupe, 1983 (P) & Junction Creek Sandstone & 34 \\
\hline 37 & Lupe, 1983 (P) & Junction Creek Sandstone & 65 \\
\hline 38 & Lupe, 1983 (P) & Junction Creek Sandstone & 99 \\
\hline 39 & Lupe, 1983 (P) & Junction Creek Sandstone & 107 \\
\hline 40 & Lupe, 1983 (P) & Junction Creek Sandstone & 208 \\
\hline 41 & Lupe, 1983 (P) & Junction Creek Sandstone & 50 \\
\hline 42 & Lupe, $1983(\mathrm{P})$ & Junction Creek Sandstone & 198 \\
\hline 43 & Lupe, 1983 (P) & Junction Creek Sandstone & 47 \\
\hline 44 & Lupe, 1983 (P) & Junction Creek Sandstone & 40 \\
\hline 45 & Lupe, 1983 (P) & Junction Creek Sandstone & 191 \\
\hline 46 & Lupe, 1983 (P) & Junction Creek Sandstone & 195 \\
\hline 47 & Lupe, 1983 (P) & Junction Creek Sandstone & 81 \\
\hline 48 & Lupe, 1983 (P) & Junction Creek Sandstone & 87 \\
\hline 49 & Lupe, 1983 (P) & Junction Creek Sandstone & 226 \\
\hline 50 & Lupe, $1983(\mathrm{P})$ & Junction Creek Sandstone & 225 \\
\hline 51 & Lupe, 1983 (P) & Junction Creek Sandstone & 223 \\
\hline 52 & Lupe, 1983 (P) & Junction Creek Sandstone & 73 \\
\hline 53 & Lupe, 1983 (P) & Junction Creek Sandstone & 262 \\
\hline
\end{tabular}


TABLE 6 (continued)

\begin{tabular}{|c|c|c|c|}
\hline $\begin{array}{l}\text { Section } \\
\text { No. }\end{array}$ & Author & Interval & $\begin{array}{l}\text { Their designation, } \\
\text { section name }\end{array}$ \\
\hline 54 & Lupe, $1983(P)$ & Junction Creek Sandstone & 274 \\
\hline 55 & Lupe, $1983(P)$ & Junction Creek Sandstone & 273 \\
\hline 56 & Lupe, $1983(\mathrm{P})$ & Junction Creek Sandstone & 113 \\
\hline 57 & Lupe, $1983(\mathrm{P})$ & Bluff Sandstone & 301 \\
\hline 58 & Lupe, $1983(P)$ & Bluff Sandstone & 302 \\
\hline 59 & Lupe, $1983(\mathrm{P})$ & Bluff Sandstone & 304 \\
\hline 60 & Lupe, 1983 (P) & Junction Creek Sandstone & 131 \\
\hline 61 & Lupe, $1983(\mathrm{P})$ & Junction Creek Sandstone & 130 \\
\hline 62 & Lupe, $1983(\mathrm{P})$ & Junction Creek Sandstone & 123 \\
\hline 63 & Lupe, $1983(\mathrm{P})$ & Junction Creek Sandstone & 128 \\
\hline 64 & Lupe, $1983(P)$ & Junction Creek Sandstone & 284 \\
\hline 65 & Wood et al., 1948 & Junction Creek Sandstone & \#1 Sullenberger \\
\hline 66 & Wood et al., 1948 & Junction Creek Sandstone & Crowley \#1 \\
\hline 67 & Wright and Dickey, 1978 & Junction Creek Sandstone & Ute Mountain \\
\hline 101 & O'Sullivan, 1980 & Bluff Sandstone & 34-Cottonwood Wash \\
\hline 102 & O'Sullivan, 1980 & Bluff Sandstone & 35-Whiskers Draw N \\
\hline 103 & O'Sullivan, 1980 & Bluff Sandstone & 36-Whiskers Draw S \\
\hline 104 & O'Sullivan, 1980 & Bluff Sandstone & 37-Butler 1 \\
\hline 105 & O'Sullivan, 1980 & Bluff Sandstone & 38 -Butler 2 \\
\hline 106 & O'Sullivan, 1980 & Bluff Sandstone & 40 - Butler 4 \\
\hline 107 & O'Sullivan, 1980 & Bluff Sandstone & 41 - Butler 5 \\
\hline 108 & Craig et al., 1959 & Bluff Sandstone & 163-Recapture Creek \\
\hline 109 & O'Sullivan, 1978 & Bluff Sandstone & 13-White Rocks Point \\
\hline 110 & O'Sullivan, 1978 & Bluff Sandstone & 12-Tohonadle \\
\hline 111 & O'Sullivan, 1978 & Bluff Sandstone & 11-Mexican Water \\
\hline 112 & O'Sullivan, 1978 & Bluff Sandstone & 10-Garnet Ridge \\
\hline 113 & O'Sullivan, 1978 & Bluff Sandstone & 8-Red Point Mesa \\
\hline 114 & F. Peterson (unpubl. data) & Bluff Sandstone & 1139-Nokaito Bench \\
\hline 115 & Condon and Huffman, 1984 & Bluff Sandstone & 7-Beclabito Dome \\
\hline 116 & Bryant, 1979 & Junction Creek Sandstone & East Snowmass Creek \\
\hline 117 & Craig et al., 1959 & Junction Creek Sandstone & $2-$ Almont \\
\hline 118 & Craig et al., 1959 & Junction Creek Sandstone & 3-Animas River \\
\hline 119 & Craig et al., 1959 & Junction Creek Sandstone & 5-Basalt \\
\hline 120 & Craig et al., 1959 & Junction Creek Sandstone & 8 - Bi Creek \\
\hline 121 & Craig et al., 1959 & Junction Creek Sandstone & 10-Black Canyon \\
\hline 122 & Wright and Wright, 1962 & Junction Creek Sandstone & 18-Slick Rock \\
\hline 123 & Craig et al., 1959 & Junction Creek Sandstone & 58-Dove Spring \\
\hline 124 & Craig et al., 1959 & Junction Creek Sandstone & 66 -Durango \\
\hline 125 & Wright and Wright, 1962 & Junction Creek Sandstone & 20-Big Canyon \\
\hline 126 & Craig et al., 1959 & Junction Creek Sandstone & 68-Egnar-Dolores River \\
\hline 127 & Craig et al., 1959 & Junction Creek Sandstone & 74-Fish Creek \\
\hline 128 & Craig et al., 1959 & Junction Creek Sandstone & 110-Leopard Creek Canyon \\
\hline 129 & Craig et al., 1959 & Junction Creek Sandstone & 120-Lookout Point \\
\hline 130 & Craig et al., 1959 & Junction Creek Sandstone & 121-Los Pinos River \\
\hline 131 & Craig et al., 1959 & Junction Creek Sandstone & 124-Lower McElmo Canyon \\
\hline 132 & Craig et al., 1959 & Junction Creek Sandstone & 125-Lower Piedra River \\
\hline 133 & Craig et al., 1959 & Bluff Sandstone & $131-$ McPhee \\
\hline 134 & Craig et al., 1959 & Junction Creek Sandstone & 132-McPhee-Dolores River \\
\hline 135 & Craig et al., 1959 & Junction Creek Sandstone & 137-May Day \\
\hline 136 & Craig et al., 1959 & Junction Creek Sandstone & 153--Ouray \\
\hline 137 & Craig et al., 1959 & Junction Creek Sandstone & 157-Pease Spring \\
\hline 138 & Craig et al., 1959 & Junction Creek Sandstone & 158-Piedra River \\
\hline 139 & Craig et al., 1959 & Junction Creek Sandstone & 179-Sapinero \\
\hline
\end{tabular}


TABLE 6 (continued)

\begin{tabular}{|c|c|c|c|}
\hline $\begin{array}{l}\text { Section } \\
\text { No. }\end{array}$ & Author & Interval & $\begin{array}{l}\text { Their designation, } \\
\text { section name }\end{array}$ \\
\hline 140 & Craig et al., 1959 & Junction Creek Sandstone & 197 -Stoner \\
\hline 141 & Craig et al., 1959 & Junction Creek Sandstone & 214-Upper McElmo Canyon \\
\hline 142 & Craig et al., 1959 & Junction Creek Sandstone & 216-Upper Piedra River \\
\hline 143 & Craig et al., 1959 & Junction Creek Sandstone & 226 - Wild Bill Canyon \\
\hline 144 & Hansen, 1968 & Junction Creek Sandstone & Pitts Meadow W \\
\hline 145 & Hansen, 1968 & Junction Creek Sandstone & Smith Ford \\
\hline 146 & Langenheim, 1957 & Junction Creek Sandstone & Almont \\
\hline 147 & Langenheim, 1957 & Junction Creek Sandstone & Brush Creek \\
\hline 148 & Langenheim, 1957 & Junction Creek Sandstone & Red Mountain \\
\hline 149 & Read et al., 1949 & Junction Creek Sandstone & Tres Piedras Ranch \\
\hline 150 & Read et al., 1949 & Junction Creek Sandstone & Trail Creek \\
\hline 151 & Cadigan, 1952 & Bluff Sandstone & 8-Lower McElmo Canyon \\
\hline 152 & Craig et al., 1959 & Junction Creek Sandstone & 99-Horseshoe Gap \\
\hline 153 & Bush et al., 1960 & Junction Creek Sandstone & Fall Creek \\
\hline 154 & Bush et al., 1960 & Bluff Sandstone & South Slope Black Ridge \\
\hline 155 & Condon, 1985a & Bluff Sandstone & Boundary Butte \\
\hline 156 & Condon, 1985a & Bluff Sandstone & Red Mesa \\
\hline 157 & Condon, 1985a & Bluff Sandstone & Toh Atin Mesa \\
\hline 158 & Condon, $1985 a$ & Bluff Sandstone & Tsitab Wash \\
\hline 201 & Lupe, 1983 & Recapture Member & 150 \\
\hline 202 & Lupe, 1983 & Recapture Member & 17 \\
\hline 203 & Lupe, 1983 & Recapture Member & 44 \\
\hline 204 & Lupe, 1983 & Recapture Member & 10 \\
\hline 205 & Lupe, 1983 & Recapture Member & 189 \\
\hline 206 & Lupe, 1983 & Recapture Member & 8 \\
\hline 207 & Lupe, 1983 & Recapture Member & 154 \\
\hline 208 & Lupe, 1983 & Recapture Member & 29 \\
\hline 209 & Lupe, 1983 & Recapture Member & 193 \\
\hline 210 & Lupe, 1983 & Recapture Member & 144 \\
\hline 211 & Lupe, 1983 & Recapture Member & 148 \\
\hline 212 & Lupe, 1983 & Recapture Member & 136 \\
\hline 213 & Lupe, 1983 & Recapture Member & 146 \\
\hline 214 & Lupe, 1983 & Recapture Member & 7 \\
\hline 215 & Lupe, 1983 & Recapture Member & 138 \\
\hline 216 & Lupe, 1983 & Recapture Member & 6 \\
\hline 217 & Lupe, 1983 & Recapture Member & 20 \\
\hline 218 & Lupe, 1983 & Recapture Member & 15 \\
\hline 219 & Lupe, 1983 & Recapture Member & 139 \\
\hline 220 & Lupe, 1983 & Recapture Member & 186 \\
\hline 301 & Craig et al., 1959 & Recapture Member & 128 -Lupton \\
\hline 302 & Craig et al., 1959 & Recapture Member & 92-Haystack Butte \\
\hline 303 & Saucier, 1967 & Recapture Member & 24-Gallup \\
\hline 304 & Saucier, 1967 & Recapture Member & 25-Pyramid Peak \\
\hline 305 & Harshbarger et al,, 1957 & Recapture Member & 27-Fort Wingate \\
\hline 306 & Kirk et al. (unpubl. data) & Recapture Member & Pinedale \\
\hline 307 & Huffman and Kirk (unpubl. data) & Recapture Member & 30-Coolidge Quarry \\
\hline 308 & Craig et al., 1959 & Recapture Member & 207-Thoreau \\
\hline 309 & Craig et al., 1959 & Recapture Member & 140-Mesa Gigante \\
\hline 310 & Craig et al., 1959 & Recapture Member & 210-Todilto Park \\
\hline 311 & Saucier, 1967 & Recapture Member & 21-Cheechilgeetho \\
\hline 312 & Peterson (unpubl. data) & Recapture Member & 1060-Black Mesa Road \\
\hline 313 & Peterson (unpubl. data) & Recapture Member & 1085-Kayenta Point \\
\hline 314 & Peterson (unpubl. data) & Recapture Member & 1111 -Salabkai Mesa \\
\hline
\end{tabular}


TABLE 6 (continued)

\begin{tabular}{|c|c|c|c|}
\hline $\begin{array}{l}\text { Section } \\
\text { No. }\end{array}$ & Author & Interval & $\begin{array}{l}\text { Their designation, } \\
\text { section name }\end{array}$ \\
\hline 315 & Peterson (unpubl. data) & Recapture Member & 1059 - Klethla Valley -361 \\
\hline 316 & Peterson (unpubl. data) & Recapture Member & 1058_-Klethla Valley-364 \\
\hline 317 & Peterson (unpubl. data) & Recapture Member & 1113 - Steamboat East \\
\hline 318 & Peterson (unpubl. data) & Recapture Member & 1055 - Lohali Point \\
\hline 319 & Peterson (unpubl. data) & Recapture Member & 1054-Tsegi \\
\hline 320 & Craig et al., 1959 & Recapture Member & 172 Saline Trading Post \\
\hline 321 & Craig et al., 1959 & Recapture Member & 230--Yale Point \\
\hline 322 & Peterson (unpubl. data) & Recapture Member & 1062-Longhouse Valley \\
\hline 323 & Peterson (unpubl. data) & Recapture Member & 1091 - Tin Yeh Toh \\
\hline 324 & Condon, 1985a & Recapture Member & 18-Lupton East \\
\hline 325 & Anderson, 1983 & Recapture Member & Taaiyalone Mesa \\
\hline 326 & Anderson, 1983 & Recapture Member & Plumosa \\
\hline 327 & Condon, 1985a & Recapture Member & 14-Pipeline Road \\
\hline 328 & Condon, $1985 b$ & Recapture Member & 1-Navajo Church \\
\hline 329 & Condon, $1985 b$ & Recapture Member & 2-Midget Mesa \\
\hline 330 & Condon, $1985 b$ & Recapture Member & 4-East Thoreau \\
\hline 332 & Condon, $1985 b$ & Recapture Member & 6-- Haystack Mountain \\
\hline 333 & Condon, $1985 b$ & Recapture Member & 16-Mannelito \\
\hline 334 & Condon, $1985 a$ & Recapture Member & 17-Lupton West \\
\hline 401 & Peterson (unpubl. data) & Temple Cap Sandstone & 525 - Leeds West \\
\hline 402 & Peterson (unpubl. data) & Temple Cap Sandstone & $535-3$-Cedar City \\
\hline 403 & Peterson (unpubl. data) & Temple Cap Sandstone & 556-Johnson Canyon \\
\hline 404 & Peterson (unpubl. data) & Temple Cap Sandstone & 557-Brown Canyon \\
\hline 405 & Peterson (unpubl. data) & Temple Cap Sandstone & 558-Kanab Canyon \\
\hline 406 & Peterson (unpubl. data) & Temple Cap Sandstone & 569-Mt. Carmel Junction \\
\hline 407 & Peterson (unpubl. data) & Temple Cap Sandstone & 570-Zican Lodge \\
\hline 408 & Peterson (unpubl. data) & Temple Cap Sandstone & 471-Potato Hollow \\
\hline 409 & Peterson (unpubl. data) & Temple Cap sandstone & 608 -Johnson Canyon W \\
\hline 410 & Peterson (unpubl. data) & Temple Cap Sandstone & 611 --Observation Point \\
\hline 411 & Peterson (unpubl. data) & Temple Cap Sandstone & 618 -Gunlock \\
\hline 412 & Peterson (unpubl. data) & Temple Cap Sandstone & 647-Elephant Butte \\
\hline 413 & Peterson (unpubl. data) & Temple Cap Sandstone & 832 - Taylor Creek \\
\hline 414 & Peterson (unpubl. data) & Temple Cap Sandstone & $834-N$ Virgin River \\
\hline 415 & Peterson (unpubl. data) & Temple Cap Sandstone & $835-\mathrm{N}$ Virgin River $\mathrm{W}$ \\
\hline 416 & Peterson (unpubl. data) & Temple Cap Sandstone & 839-Moapa Stake \\
\hline 417 & Peterson (unpubl. data) & Temple Cap Sandstone & 840 -Pocket Hollow N \\
\hline 418 & Peterson (unpubl. data) & Temple Cap Sandstone & 843-Mineral Mountains \\
\hline 501 & Peterson (unpubl. data) & Romana Sandstone & 278-Kane Creek \\
\hline 502 & Peterson (unpubl. data) & Romana Sandstone & 770-Crosby Canyon \\
\hline 503 & Peterson (unpubl. data) & Romana Sandstone & 277-Last Chance Bay E \\
\hline 504 & Peterson (unpubl. data) & Romana Sandstone & 304 -Cummings Mesa W \\
\hline 505 & Peterson (unpubl. data) & Romana Sandstone & 420 - Twin Red Buttes \\
\hline 506 & Peterson (unpubl. data) & Romana Sandstone & $\mathrm{Jb}-\mathrm{B}-$ Cotton Point \\
\hline 507 & Peterson (unpubl. data) & Romana Sandstone & 384-Torera Point \\
\hline 508 & Peterson (unpubl. data) & Romana Sandstone & 679-Castle Rock \\
\hline 509 & Peterson (unpubl. data) & Romana Sandstone & 418-Leche-e Rock \\
\hline 510 & Peterson (unpubl. data) & Romana Sandstone & 381-Cummings Mesa Trai \\
\hline 511 & Peterson (unpubl. data) & Romana Sandstone & 408 - Square Butte \\
\hline 512 & Peterson (unpubl. data) & Romana Sandstone & 407-Tsai Skizzie \\
\hline 601 & Sacrison, 1958 & Unkpapa Sandstone & 1-Parker Creek \\
\hline 602 & Sacrison, 1958 & Unkpapa Sandstone & 2-Hell Canyon \\
\hline 603 & Sacrison, 1958 & Unkpapa Sandstone & 3-Falls Canyon \\
\hline 604 & Sacrison, 1958 & Unkpapa Sandstone & 4-Alabaugh Canyon \\
\hline 605 & Sacrison, 1958 & Unkpapa Sandstone & 5-Sheps Canyon \\
\hline 606 & Sacrison, 1958 & Unkpapa Sandstone & 6-Hot Springs \\
\hline
\end{tabular}


TABLE 6 (continued)

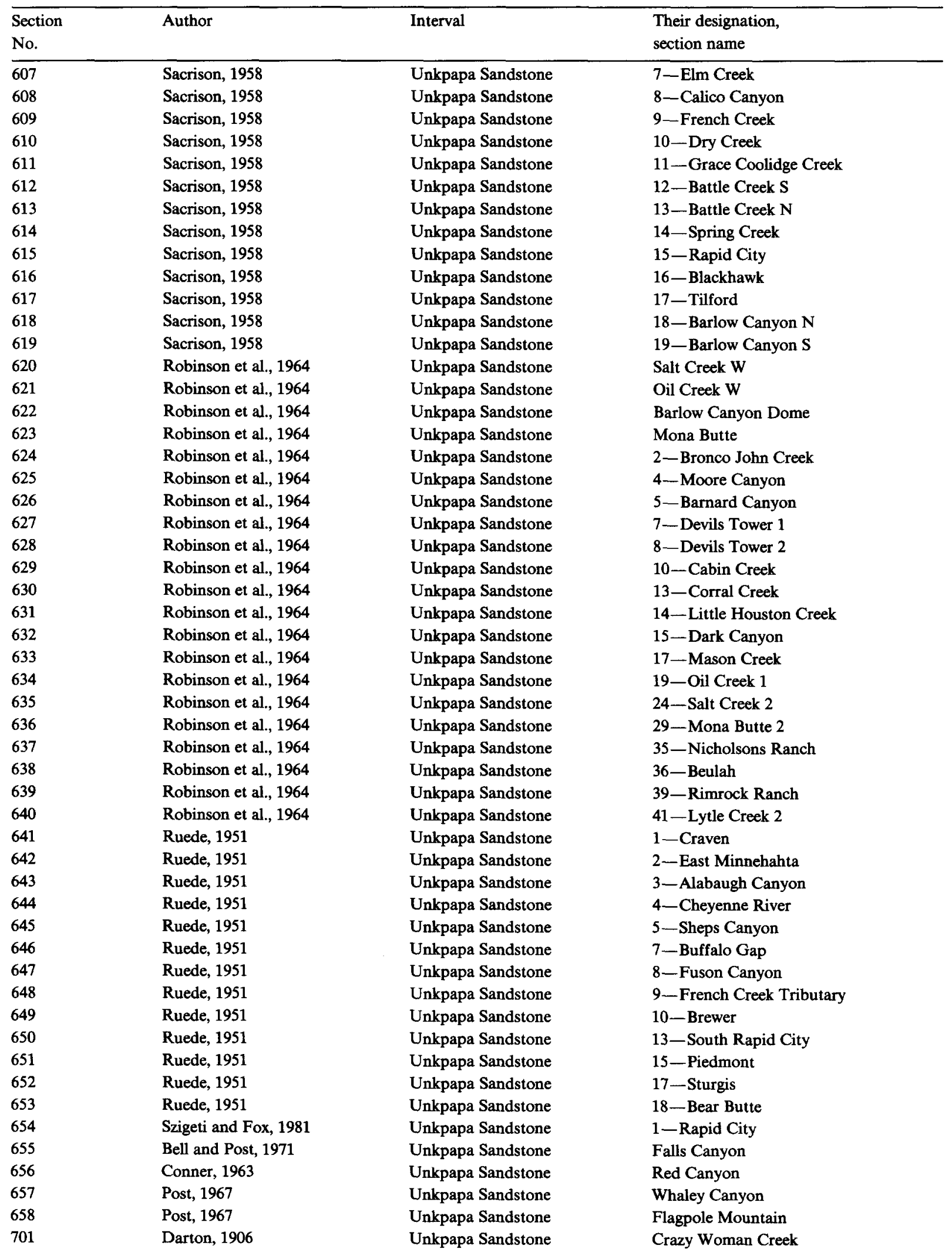


TABLE 6 (continued)

\begin{tabular}{|c|c|c|c|}
\hline $\begin{array}{l}\text { Section } \\
\text { No. }\end{array}$ & Author & Interval & $\begin{array}{l}\text { Their designation, } \\
\text { section name }\end{array}$ \\
\hline 702 & Darton, 1906 & Unkpapa Sandstone & Beaver Creek \\
\hline 703 & Darton, 1906 & Unkpapa Sandstone & S Fork of Rock Creek \\
\hline 704 & Darton, 1906 & Unkpapa Sandstone & Muddy Creek S. \\
\hline 705 & Darton, 1906 & Unkpapa Sandstone & Tongue River \\
\hline 706 & Darton, 1906 & Unkpapa Sandstone & Tensleep \\
\hline 707 & Love et al., 1945 & Unkpapa Sandstone & Thermopolis \\
\hline 708 & Darton, 1906 & Unkpapa Sandstone & Alkali Creek \\
\hline 709 & Keefer and Treger, 1964 & Unkpapa Sandstone & E Sheep Creek \\
\hline 710 & Love et al., 1947 & Unkpapa Sandstone & Horse Creek \\
\hline 711 & Love et al., 1947 & Unkpapa Sandstone & Red Grade \\
\hline 712 & Love et al., 1947 & Unkpapa Sandstone & Mill Creek \\
\hline 713 & Love et al., 1947 & Unkpapa Sandstone & Derby Dome \\
\hline 714 & Love et al., 1947 & Unkpapa Sandstone & Conant Creek \\
\hline 715 & Love et al., 1947 & Unkpapa Sandstone & Duton Basin \\
\hline 716 & Love et al., 1945b & Unkpapa Sandstone & 13-Lander Anticline \\
\hline 717 & Love et al., 1945a & Unkpapa Sandstone & 16-Squaw Creek \\
\hline 718 & Love et al., 1945a & Unkpapa Sandstone & 17--Dallas Anticline \\
\hline 719 & Love et al., 1945a & Unkpapa Sandstone & 18-Derby Anticline \\
\hline 720 & Love et al., 1945a & Unkpapa Sandstone & 21-Bison Basin Anticline \\
\hline 721 & Love et al., 1945a & Unkpapa Sandstone & 23-Big Sand Draw \\
\hline 722 & Love et al., $1945 \mathrm{a}$ & Unkpapa Sandstone & 25-Muskrat Anticline \\
\hline 723 & Pipiringos, 1968 & Unkpapa Sandstone & 42 - Freezout Mountains SW \\
\hline 724 & Peterson (unpub. data) & Unkpapa Sandstone & $44-$ Freezout Mountains E \\
\hline 725 & D.H. Uhler (unpubl. data) & Unkpapa Sandstone & Alcove \\
\hline 726 & D.H. Uhler (unpubl. data) & Unkpapa Sandstone & Thermopolis-Van Norman \\
\hline 727 & D.H. Uhler (unpubl. data) & Unkpapa Sandstone & Baker Cabin Road \\
\hline 728 & D.H. Uhler (unpubl. data) & Unkpapa Sandstone & Barnum \\
\hline 729 & Love et al., $1945 b$ & Unkpapa Sandstone & 8-Winkleman Anticline \\
\hline 730 & Love et al., $1945 b$ & Unkpapa Sandstone & 10-Sage Creek Anticline \\
\hline 731 & Love et al., $1945 b$ & Unkpapa Sandstone & 14-Wyopo \\
\hline 732 & Love et al., $1945 b$ & Unkpapa Sandstone & 15-Sulfur Springs \\
\hline 733 & Love et al., 1945b & Unkpapa Sandstone & 17-Beaver Creek Anticline \\
\hline 734 & Love et al., 1945b & Unkpapa Sandstone & 24-Kirby Creek Anticline \\
\hline 735 & Love et al., $1945 \mathrm{~b}$ & Unkpapa Sandstone & 25-Black Mountain Anticline \\
\hline 736 & Love et al., 1945b & Unkpapa Sandstone & 26 -Aominto \\
\hline 737 & Love et al., 1945b & Unkpapa Sandstone & 27-South Mayoworth \\
\hline 738 & Love et al., $1945 b$ & Unkpapa Sandstone & 28 -North Mayoworth \\
\hline 739 & Pipiringos and O'Sullivan, 1976 & Unkpapa Sandstone & 3-Manning Ridge NW \\
\hline 740 & Pipiringos and O'Sullivan, 1976 & Unkpapa Sandstone & 4-Manning Ridge SE \\
\hline
\end{tabular}


TABLE 7

Data base for Page Sandstone and Entrada Sandstone

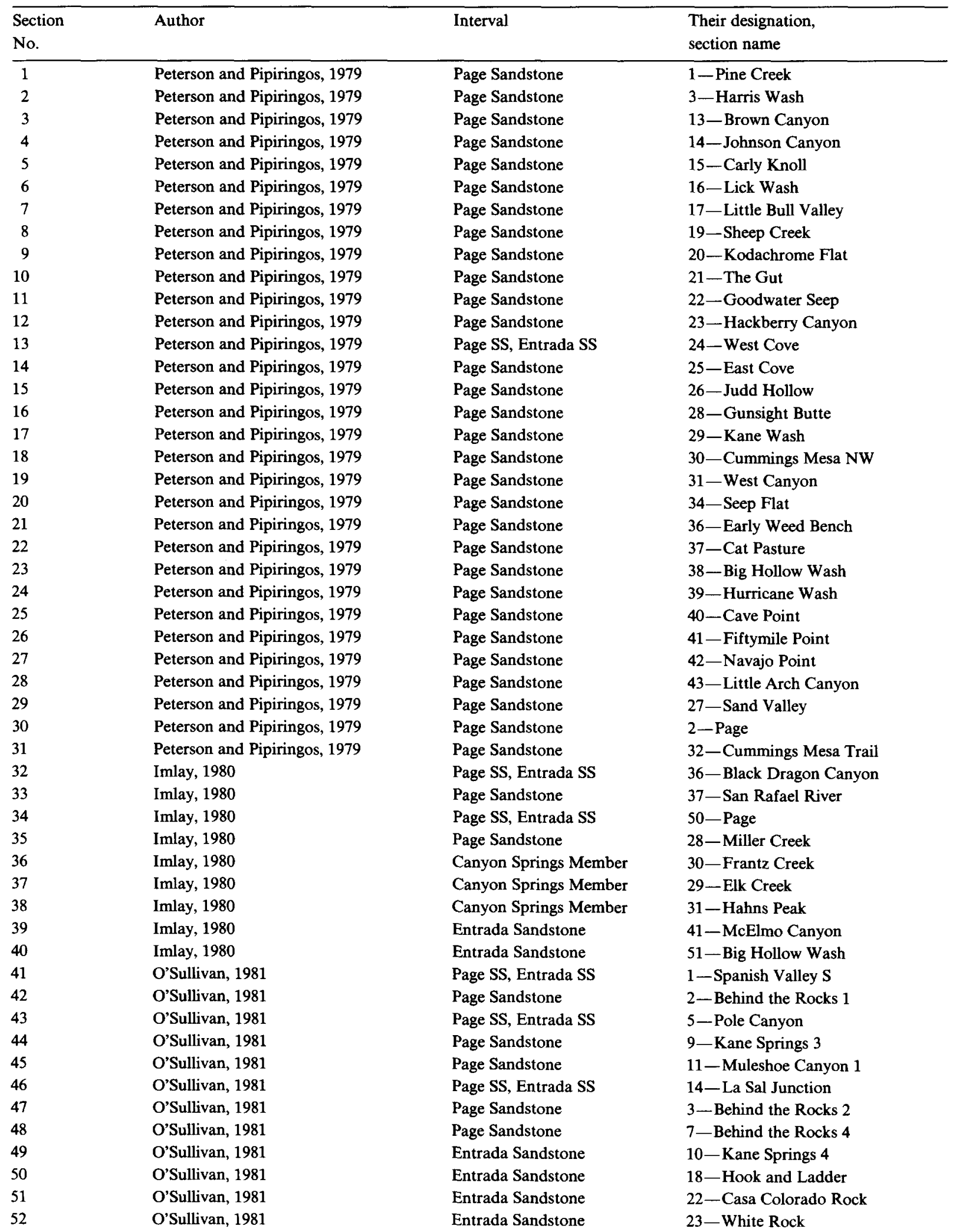


TABLE 7 (continued)

\begin{tabular}{|c|c|c|c|}
\hline $\begin{array}{l}\text { Section } \\
\text { No. }\end{array}$ & Author & Interval & $\begin{array}{l}\text { Their designation, } \\
\text { section name }\end{array}$ \\
\hline 53 & O'Sullivan, 1981 & Entrada Sandstone & 24-East Canyon \\
\hline 54 & O'Sullivan, 1981 & Entrada Sandstone & 25-Day Wash A \\
\hline 55 & O'Sullivan, 1981 & Entrada Sandstone & 29-Three Step Hill E. \\
\hline 56 & O'Sullivan, 1981 & Entrada Sandstone & $30-$ Mclntyre 1 \\
\hline 57 & O'Sullivan, 1981 & Entrada Sandstone & 31 -McIntyre 2 \\
\hline 58 & O’Sullivan, 1981 & Entrada Sandstone & 33-Slick Rock \\
\hline 59 & O'Sullivan, 1981 & Entrada Sandstone & 4 - Behind the Rocks 3 \\
\hline 60 & O'Sullivan, 1981 & Entrada Sandstone & 9-Kane Springs 2 \\
\hline 61 & O'Sullivan, 1981 & Entrada Sandstone & 12-Muleshoe Canyon 2 \\
\hline 62 & O'Sullivan, 1981 & Entrada Sandstone & 13-La Sal Junction, NW \\
\hline 63 & O'Sullivan, 1981 & Entrada Sandstone & 15-West Coyote \\
\hline 64 & O’Sullivan, 1981 & Entrada Sandstone & 19-Wilson Arch, S \\
\hline 65 & O'Sullivan, 1981 & Entrada Sandstone & 20 -Lopez Gulch 1 \\
\hline 66 & Caputo, 1980 & Page Sandstone & Paria Canyon Primitive Area \\
\hline 67 & Caputo, 1980 & Page Sandstone & Catstairs Canyon \\
\hline 68 & Caputo, 1980 & Page Sandstone & Cottonwood Creek A \\
\hline 69 & Caputo, 1980 & Page Sandstone & Cottonwood Creek B \\
\hline 70 & Caputo, 1980 & Page Sandstone & Cottonwood Creek C \\
\hline 71 & Caputo, 1980 & Page Sandstone & Rock Springs Creek \\
\hline 72 & Caputo, 1980 & Page Sandstone & Bull Valley Gorge D \\
\hline 73 & Caputo, 1980 & Page Sandstone & Deer Springs Ranch \\
\hline 74 & O'Sullivan and Peirce, 1983 & Page Sandstone & 12-Tenmile Butte $N$ \\
\hline 75 & O'Sullivan and Peirce, 1983 & Page Sandstone & 13-The Needles \\
\hline 76 & O'Sullivan and Peirce, 1983 & Page Sandstone & 14-Dubinky W \\
\hline 77 & O'Sullivan and Peirce, 1983 & Page Sandstone & 18 - Courthhouse Rock \\
\hline 78 & O'Sullivan and Peirce, 1983 & Page Sandstone & 41-Lightning Draw $S$ \\
\hline 79 & O'Sullivan and Peirce, 1983 & Page Sandstone & 42-Photo Gap N \\
\hline 80 & O'Sullivan and Peirce, 1983 & Page Sandstone & 43-Photo Gap \\
\hline 81 & O'Sullivan and Peirce, 1983 & Page Sandstone & 44-Photo Gap S \\
\hline 82 & O'Sullivan and Peirce, 1983 & Page Sandstone & 9-Duma Point \\
\hline 83 & O'Sullivan and Peirce, 1983 & Page Sandstone & 17-Bartlett Wash E \\
\hline 84 & O'Sullivan and Peirce, 1983 & Page Sandstone & 19-Sevenmile Canyon \\
\hline 85 & O'Sullivan and Peirce, 1983 & Page Sandstone & 24-Muleshoe Canyon 2 \\
\hline 86 & O'Sullivan and Peirce, 1983 & Page Sandstone & 30-Looking Glass Rock \\
\hline 87 & O'Sullivan and Peirce, 1983 & Page Sandstone & 31 - Hatch Rock \\
\hline 88 & O'Sullivan and Pipiringos, 1983 & Entrada Sandstone & 3-Cottonwood Canyon \\
\hline 89 & O'Sullivan and Pipiringos, 1983 & Entrada Sandstone & 6-Granite Creek \\
\hline 90 & O'Sullivan and Pipiringos, 1983 & Entrada Sandstone & 8--Buchkhorn Mesa \\
\hline 91 & O'Sullivan and Pipiringos, 1983 & Entrada Sandstone & 12 -Westwater \\
\hline 92 & O'Sullivan and Pipiringos, 1983 & Entrada Sandstone & 13-Ruby Canyon \\
\hline 93 & O'Sullivan and Pipiringos, 1983 & Entrada Sandstone & 14-Rabbit Valley \\
\hline 94 & O'Sullivan and Pipiringos, 1983 & Entrada Sandstone & 16 -Loma \\
\hline 95 & O'Sullivan and Pipiringos, 1983 & Entrada Sandstone & 17-Rattlesnake Canyon \\
\hline 96 & O'Sullivan and Pipiringos, 1983 & Entrada Sandstone & 18 -Fruita \\
\hline 97 & O'Sullivan and Pipiringos, 1983 & Entrada Sandstone & 19-Coke Ovens \\
\hline 98 & O'Sullivan and Pipiringos, 1983 & Entrada Sandstone & 20 -Rough Canyon \\
\hline 99 & O'Sullivan and Pipiringos, 1983 & Entrada Sandstone & 21-Cactus Park \\
\hline 100 & O'Sullivan and Pipiringos, 1983 & Entrada Sandstone & 22-Bridgeport \\
\hline 101 & O'Sullivan, 1984 & Entrada Sandstone & 1-Dewey Bridge \\
\hline 102 & O'Sullivan, 1984 & Entrada Sandstone & 2-Blue Chief Mesa \\
\hline 103 & O'Sullivan, 1984 & Entrada Sandstone & 3-Bridge Canyon \\
\hline 104 & O'Sullivan, 1984 & Entrada Sandstone & 9-Lumsden Canyon \\
\hline 105 & O'Sullivan, 1984 & Entrada Sandstone & 10-John Brown Canyon \\
\hline
\end{tabular}


TABLE 7 (continued)

\begin{tabular}{|c|c|c|c|}
\hline $\begin{array}{l}\text { Section } \\
\text { No. }\end{array}$ & Author & Interval & $\begin{array}{l}\text { Their designation, } \\
\text { section name }\end{array}$ \\
\hline 106 & O'Sullivan, 1984 & Entrada Sandstone & 11-Cave Canyon \\
\hline 107 & O'Sullivan, 1984 & Entrada Sandstone & 13-Tenderfoot Mesa A \\
\hline 108 & O'Sullivan, 1984 & Entrada Sandstone & 14-Maverick Canyon B \\
\hline 109 & O'Sullivan, 1984 & Entrada Sandstone & 16-Flat Top Mesa \\
\hline 110 & O'Sullivan, 1984 & Entrada Sandstone & 17-Calamity Mesa SW \\
\hline 111 & O'Sullivan, 1984 & Entrada Sandstone & 18-Blue Creek \\
\hline 112 & O'Sullivan, 1984 & Entrada Sandstone & 20-Beehive Canyon \\
\hline 113 & O'Sullivan, 1984 & Entrada Sandstone & 24-Uravan \\
\hline 114 & Wright and Dickey, 1979 & Entrada Sandstone & 69-Crystal \\
\hline 115 & Wright and Dickey, 1979 & Entrada Sandstone & 75-Twin Buttes Wash \\
\hline 116 & O'Sullivan, 1984 & Entrada Sandstone & 15-Bartlett Wash W \\
\hline 117 & O'Sullivan, 1984 & Entrada Sandstone & 17-Mill Canyon \\
\hline 118 & O'Sullivan, 1984 & Entrada Sandstone & 8-Duma Point \\
\hline 119 & O'Sullivan, 1984 & Entrada Sandstone & 9-Tenmile Canyon W \\
\hline 120 & O'Sullivan, 1984 & Entrada Sandstone & 10-Tenmile Canyon E \\
\hline 121 & O'Sullivan, 1984 & Entrada Sandstone & 11 - Tenmile Butte $\mathrm{N}$ \\
\hline 122 & O'Sullivan, 1984 & Entrada Sandstone & 12-Tenmile Butte \\
\hline 123 & O'Sullivan, 1984 & Entrada Sandstone & 13-Dubinky W \\
\hline 124 & O'Sullivan, 1984 & Entrada Sandstone & 14-Dubinky E \\
\hline 125 & O'Sullivan, 1984 & Entrada Sandstone & 16-Bartlett Wash E \\
\hline 126 & O'Sullivan, 1980 & Entrada Sandstone & 1-Wilson Arch \\
\hline 127 & O'Sullivan, 1980 & Entrada Sandstone & 3-Hatch Rock \\
\hline 128 & O'Sullivan, 1980 & Entrada Sandstone & 5-Wind Whistle Draw \\
\hline 129 & O'Sullivan, 1980 & Entrada Sandstone & 8-Rone Bailey 3 \\
\hline 130 & O'Sullivan, 1980 & Entrada Sandstone & 15-Photo Gap \\
\hline 131 & O'Sullivan, 1980 & Entrada Sandstone & 21 - Harts 1 \\
\hline 132 & O'Sullivan, 1980 & Entrada Sandstone & 22-Indian Creek E \\
\hline 133 & O'Sullivan, 1980 & Entrada Sandstone & 24-Shay Mountain \\
\hline 134 & O'Sullivan, 1980 & Entrada Sandstone & 26-Mt. Linnaeus \\
\hline 135 & O'Sullivan, 1980 & Entrada Sandstone & 29-Mancos Jim Butte \\
\hline 136 & O'Sullivan, 1980 & Entrada Sandstone & 33-Black Steer Knoll \\
\hline 137 & O’Sullivan, 1980 & Entrada Sandstone & 37-Butler 1 \\
\hline 138 & O'Sullivan, 1980 & Entrada Sandstone & $40-$ Butler 4 \\
\hline 139 & O'Sullivan, 1980 & Entrada Sandstone & $42-$ Butler 6 \\
\hline 140 & O'Sullivan, 1980 & Entrada Sandstone & $49-$ Butler 13 \\
\hline 141 & O'Sullivan, 1980 & Entrada Sandstone & $51-$ Bluff W \\
\hline 142 & O'Sullivan, 1980 & Entrada Sandstone & 9-Rone Bailey SE 1 \\
\hline 143 & O'Sullivan, 1980 & Entrada Sandstone & 7-Rone Bailey 2 \\
\hline 144 & O'Sullivan, 1980 & Entrada Sandstone & 4-Rone Bailey 1 \\
\hline 145 & O'Sullivan, 1980 & Entrada Sandstone & 2-Looking Glass Rock \\
\hline 146 & Wright and Dickey, 1978 & Entrada Sandstone & 4-Cedar Mountain \\
\hline 147 & Wright and Dickey, 1978 & Entrada Sandstone & 18-Pine Creek \\
\hline 148 & Wright and Dickey, 1978 & Entrada Sandstone & 26-Little Wild Horse Mesa \\
\hline 149 & Wright and Dickey, 1978 & Entrada Sandstone & 28-Granite Ranch \\
\hline 150 & Wright and Dickey, 1978 & Entrada Sandstone & $221-249$ Flat Top Buttes \\
\hline 151 & Wright and Dickey, 1978 & Entrada Sandstone & 225-Johns Valley Calf Co \#1 \\
\hline 152 & Wright and Dickey, 1978 & Entrada Sandstone & 299-Pulpit Arch \\
\hline 153 & Wright and Dickey, 1978 & Entrada Sandstone & 372-Barx-Frontier-Stanolind \\
\hline 154 & Wright and Dickey, 1978 & Entrada Sandstone & 378 -Phillips Petro. Two Waters \#1 \\
\hline 155 & Wright and Dickey, 1978 & Entrada Sandstone & 380-Hill Creek Carter Oil Co \\
\hline 156 & Wright and Dickey, 1978 & Entrada Sandstone & 476-Phillips Petrol. Watson "B" \#1 \\
\hline 157 & Wright and Dickey, 1978 & Entrada Sandstone & 14-Fremont River \\
\hline
\end{tabular}


TABLE 7 (continued)

\begin{tabular}{|c|c|c|c|}
\hline $\begin{array}{l}\text { Section } \\
\text { No. }\end{array}$ & Author & Interval & $\begin{array}{l}\text { Their designation, } \\
\text { section name }\end{array}$ \\
\hline 158 & Wright and Dickey, 1978 & Entrada Sandstone & 16--Burro Wash Notom Bench \\
\hline 159 & Wright and Dickey, 1978 & Entrada Sandstone & 17-Red Slide \\
\hline 160 & Wright and Dickey, 1978 & Entrada Sandstone & $20-$ Navajo Point \\
\hline 161 & Wright and Dickey, 1978 & Entrada Sandstone & 21 -Catstairs \\
\hline 162 & Wright and Dickey, 1978 & Entrada Sandstone & 22-Paria Amphitheater \\
\hline 163 & Wright and Dickey, 1978 & Entrada Sandstone & 24-Baker Ranch, Halls Creek \\
\hline 164 & Wright and Dickey, 1978 & Entrada Sandstone & $42-$ Wahweap \\
\hline 165 & Wright and Dickey, 1978 & Entrada Sandstone & 44-Adairville \\
\hline 166 & Wright and Dickey, 1978 & Entrada Sandstone & 47-American Liberty Gov \#1 \\
\hline 167 & Wright and Dickey, 1978 & Entrada Sandstone & 70 -Crossing of the Fathers \\
\hline 168 & Wright and Dickey, 1978 & Entrada Sandstone & 84-The Gut \\
\hline 169 & Wright and Dickey, 1978 & Entrada Sandstone & 205 -Bitter Spring Seep \\
\hline 170 & Wright and Dickey, 1978 & Entrada Sandstone & 206-Muley Twist \\
\hline 171 & Wright and Dickey, 1978 & Entrada Sandstone & 214 Muddy River W \\
\hline 172 & Wright and Dickey, 1978 & Entrada Sandstone & 215-Starvation Point \\
\hline 173 & Wright and Dickey, 1978 & Entrada Sandstone & 281-Muddy River E \\
\hline 174 & Wright and Dickey, 1978 & Entrada Sandstone & 6-San Rafael Reef \\
\hline 175 & Wright and Dickey, 1978 & Entrada Sandstone & 12 - Horn Silver Gulch \\
\hline 176 & Wright and Dickey, 1978 & Entrada Sandstone & $16-98$ Notom \\
\hline 177 & Wright and Dickey, 1978 & Entrada Sandstone & 23-Teasdale \\
\hline 178 & Wright and Dickey, 1978 & Entrada Sandstone & 149-Dove Spring \\
\hline 179 & Wright and Dickey, 1978 & Entrada Sandstone & 222-Farnham Dome Mtn Full \#1 \\
\hline 180 & Wright and Dickey, 1978 & Entrada Sandstone & 223-Grassy Trail Cities Service Fed \#1 \\
\hline 181 & Wright and Dickey, 1978 & Entrada Sandstone & 347 - Salina Canyon \\
\hline 182 & Wright and Dickey, 1978 & Entrada Sandstone & $350-\mathrm{K}-\mathrm{Ranch} \mathrm{CO}-$ UT Border \\
\hline 183 & Wright and Dickey, 1978 & Entrada Sandstone & 351 -Willow Creek \\
\hline 184 & Wright and Dickey, 1978 & Entrada Sandstone & 516-Ute Mtn Cont. Oil Co. \#3 \\
\hline 185 & Wright and Dickey, 1978 & Entrada Sandstone & 522 - Cont. Oil Co $\# 1$ \\
\hline 186 & Johnston, 1975 & Entrada Sandstone & Tonalea \\
\hline 187 & Johnston, 1975 (K) & Entrada Sandstone & Dangling Rope \\
\hline 188 & Johnston, $1975(\mathrm{~K})$ & Entrada Sandstone & Warm Creek \\
\hline 189 & Johnston, $1975(\mathrm{~K})$ & Entrada Sandstone & NE Cummings Mesa \\
\hline 190 & Johnston, $1975(\mathrm{~K})$ & Entrada Sandstone & W Cummings Mesa \\
\hline 191 & Johnston, 1975 & Entrada Sandstone & Elephant's Feet \\
\hline 192 & Johnston, 1975 & Entrada Sandstone & Coal Mine \\
\hline 193 & Johnston, 1975 & Entrada Sandstone & Blue Canyon \\
\hline 194 & Johnston, 1975 & Entrada Sandstone & SW White Mesa \\
\hline 195 & Johnston, 1975 & Entrada Sandstone & NE White Mesa \\
\hline 196 & Johnston, $1975(\mathrm{~K})$ & Entrada Sandstone & Tse Skizzi \\
\hline 197 & Johnston, 1975 & Entrada Sandstone & NW Coal Mine \\
\hline 198 & Johnston, 1975 & Entrada Sandstone & Cow Springs \\
\hline 199 & Johnston, $1975(\mathrm{~K})$ & Entrada Sandstone & Window Rock \\
\hline 200 & Johnston, 1975 & Entrada Sandstone & Kaibito \\
\hline 201 & Johnston, $1975(\mathrm{~K})$ & Entrada Sandstone & Lechee-e Rock \\
\hline 202 & Johnston, 1975 & Entrada Sandstone & Wahweap \\
\hline 203 & Pipiringos and O'Sullivan, 1976 & Entrada Sandstone & 10-Boundary Line \\
\hline 204 & Pipiringos and O'Sullivan, 1976 & Entrada Sandstone & 11-Sand Creek \\
\hline 205 & Pipiringos and O'Sullivan, 1976 & Entrada Sandstone & 12-Table Mountain \\
\hline 206 & Pipiringos and O'Sullivan, 1976 & Entrada Sandstone & 13-Box Elder Creek $N$ \\
\hline 207 & Pipiringos and O'Sullivan, 1976 & Entrada Sandstone & 14-Box Elder Creek S \\
\hline 208 & Pipiringos and O'Sullivan, 1976 & Entrada Sandstone & 15-Park Creek \\
\hline 209 & Pipiringos and O’Sullivan, 1976 & Entrada Sandstone & 16-Owl Canyon \\
\hline 210 & Pipiringos and O'Sullivan, 1976 & Entrada Sandstone & 17 -Bellvue \\
\hline
\end{tabular}


TABLE 7 (continued)

\begin{tabular}{|c|c|c|c|}
\hline $\begin{array}{l}\text { Section } \\
\text { No. }\end{array}$ & Author & Interval & $\begin{array}{l}\text { Their designation, } \\
\text { section name }\end{array}$ \\
\hline 211 & Pipiringos and O'Sullivan, 1976 & Entrada Sandstone & 19-Loveland \\
\hline 212 & Pipiringos and O'Sullivan, 1976 & Entrada Sandstone & 20-Dry Creek \\
\hline 213 & Pipiringos and O'Sullivan, 1976 & Entrada Sandstone & 21-Litle Thompson \\
\hline 214 & Pipiringos and O'Sullivan, 1976 & Entrada Sandstone & 22-Four Mile Canyon \\
\hline 215 & Pipiringos and O'Sullivan, 1976 & Entrada Sandstone & 23-Ralston Reservoir \\
\hline 216 & Pipiringos and O'Sullivan, 1976 & Entrada Sandstone & 9-Mesa Mountain \\
\hline 217 & Pipiringos and O'Sullivan, 1976 & Entrada Sandstone & 8-Horse Creek \\
\hline 218 & Pipiringos and O'Sullivan, 1976 & Entrada Sandstone & 7-Farthing \\
\hline 219 & Pipiringos and O'Sullivan, 1976 & Entrada Sandstone & 6-Chugwater Creek \\
\hline 220 & Pipiringos and O'Sullivan, 1976 & Entrada Sandstone & 5-Horseshoe Creek \\
\hline 221 & Pipiringos and O'Sullivan, 1976 & Entrada Sandstone & 4-Manning Ridge SE \\
\hline 222 & Pipiringos and O'Sullivan, 1976 & Entrada Sandstone & 3-Manning Ridge NW \\
\hline 223 & Pipiringos and O'Sullivan, 1976 & Entrada Sandstone & 2-Sage Hen Anticline \\
\hline 224 & Pipiringos and O'Sullivan, 1976 & Entrada Sandstone & 1 -Douglas \\
\hline 225 & O'Sullivan, 1978 & Entrada Sandstone & 1-Lohali Point \\
\hline 226 & O'Sullivan, 1978 & Entrada Sandstone & 2-White Hills \\
\hline 227 & O'Sullivan, 1978 & Entrada Sandstone & 3-White Top Mesa \\
\hline 228 & O'Sullivan, 1978 & Entrada Sandstone & 4-White Top Mesa S \\
\hline 229 & O'Sullivan, 1978 & Entrada Sandstone & 5- White Top Mesa \\
\hline 230 & O’Sullivan, 1978 & Entrada Sandstone & 8-Red Point Mesa \\
\hline 231 & O'Sullivan, 1978 & Entrada Sandstone & 9-Red Point \\
\hline 232 & O'Sullivan, 1978 & Entrada Sandstone & 10-Garnet Ridge \\
\hline 233 & O'Sullivan, 1978 & Entrada Sandstone & 11-Mexican Water \\
\hline 234 & O'Sullivan, 1978 & Entrada Sandstone & 12-Tohonadla \\
\hline 235 & O’Sullivan, 1978 & Entrada Sandstone & 13-White Rock Point \\
\hline 236 & Wright et al., 1962 & Entrada Sandstone & 1-San Rafael River \\
\hline 237 & Wright et al., 1962 & Entrada Sandstone & 3-Ten Mile Wash \\
\hline 238 & Wright et al., 1962 & Entrada Sandstone & 4-Ten Mile Butte \\
\hline 239 & Wright et al., 1962 & Entrada Sandstone & 6-Arches \\
\hline 240 & Wright et al., 1962 & Entrada Sandstone & 12-Mill Creek \\
\hline 241 & Wright et al., 1962 & Entrada Sandstone & 13-Cane Springs \\
\hline 242 & Wright et al., $1962(\mathrm{~K})$ & Entrada Sandstone & 19-Horseshoe Group \\
\hline 243 & Wright et al., $1962(\mathrm{~K})$ & Entrada Sandstone & 20-Big Canyon \\
\hline 244 & Otto and Picard, 1975 & Entrada Sandstone & $\# 1$ \\
\hline 245 & Otto and Picard, 1975 & Entrada Sandstone & $\# 3$ \\
\hline 246 & Otto and Picard, 1975 & Entrada Sandstone & $\# 4$ \\
\hline 247 & Otto and Picard, 1975 & Entrada Sandstone & \#6 \\
\hline 248 & Otto and Picard, 1975 & Entrada Sandstone & $\# 7$ \\
\hline 249 & Otto and Picard, 1975 & Entrada Sandstone & $\# 11$ \\
\hline 250 & Otto and Picard, 1975 & Entrada Sandstone & $\# 12$ \\
\hline 251 & Otto and Picard, 1975 & Entrada Sandstone & $\# 13$ \\
\hline 252 & Wright et al., 1980 & Entrada Sandstone & 19-Collet Creek \\
\hline 253 & Kocurek, 1980 & Entrada Sandstone & W Manila \\
\hline 254 & Kocurek, 1980 & Entrada Sandstone & Dagget City Dump \\
\hline 255 & Kocurek, 1980 & Entrada Sandstone & Steinaker \\
\hline 256 & Kocurek, 1980 & Entrada Sandstone & Dinosaur \\
\hline 257 & Kocurek, 1980 & Entrada Sandstone & Chew Ranch \\
\hline 258 & Kocurek, 1980 & Entrada Sandstone & Plug Hat Butte \\
\hline 259 & Kocurek, 1980 & Entrada Sandstone & Blue Mountain \\
\hline 260 & Kocurek, 1980 & Entrada Sandstone & Skull Creek \\
\hline 261 & Kocurek, 1980 & Entrada Sandstone & Elk Springs \\
\hline 262 & Kocurek, 1980 & Entrada Sandstone & Vermillion Creek \\
\hline
\end{tabular}


TABLE 7 (continued)

\begin{tabular}{|c|c|c|c|}
\hline $\begin{array}{l}\text { Section } \\
\text { No. }\end{array}$ & Author & Interval & $\begin{array}{l}\text { Their designation, } \\
\text { section name }\end{array}$ \\
\hline 263 & Kocurek, 1980 & Entrada Sandstone & Meeker \\
\hline 264 & Kocurek, 1980 & Entrada Sandstone & Wolcott \\
\hline 265 & Kocurek, 1980 & Entrada Sandstone & Derby Creek \\
\hline 266 & Thomas and Kreuger, 1946 & Entrada Sandstone & Lake Fork \\
\hline 267 & Thomas and Kreuger, 1946 & Entrada Sandstone & Whiterocks Canyon \\
\hline 268 & Thomas and Kreuger, 1946 & Entrada Sandstone & Vernal \\
\hline 269 & Thomas and Kreuger, 1946 & Entrada Sandstone & Split Mountain \\
\hline 270 & Cater, 1970 & Entrada Sandstone & Dolores \\
\hline 271 & Davidson, 1967 & Entrada Sandstone & $\# 16$ \\
\hline 272 & Peterson (unpubl. data) & Entrada Sandstone & Pine Creek \\
\hline 273 & Huff and Leswe, 1965 & Entrada Sandstone & $\# 1$ \\
\hline 274 & Baker, 1946 & Entrada Sandstone & p. 77 \\
\hline 275 & Baker, 1946 & Entrada Sandstone & p. 77 \\
\hline 276 & O'Sullivan, 1965 & Entrada Sandstone & p. 75 \\
\hline 277 & O'Sullivan, 1965 & Entrada Sandstone & p. 76 \\
\hline 278 & Ver Hoeve, 1982 & Entrada Sandstone & $\# 12$ \\
\hline 279 & Ver Hoeve, 1982 & Entrada Sandstone & $\# 26$ \\
\hline 280 & Ver Hoeve, 1982 & Entrada Sandstone & $\# 37$ \\
\hline 281 & Ver Hoeve, 1982 & Entrada Sandstone & $\# 34$ \\
\hline 282 & Lupe, 1983 & Entrada Sandstone & $\# 306$ \\
\hline 283 & Lupe, 1983 & Entrada Sandstone & $\# 307$ \\
\hline 284 & Lupe, 1983 & Entrada Sandstone & $\# 310$ \\
\hline 285 & Lupe, 1983 & Entrada Sandstone & $\# 123$ \\
\hline 286 & Lupe, 1983 & Entrada Sandstone & $\# 320$ \\
\hline 287 & Lupe, 1983 & Entrada Sandstone & $\# 315$ \\
\hline 288 & Lupe, 1983 & Entrada Sandstone & $\# 268$ \\
\hline 289 & Lupe, 1983 & Entrada Sandstone & $\# 283$ \\
\hline 290 & Lupe, 1983 & Entrada Sandstone & $\# 132$ \\
\hline 291 & Lupe, 1983 & Entrada Sandstone & $\# 130$ \\
\hline 292 & Lupe, 1983 & Entrada Sandstone & $\# 123$ \\
\hline 293 & Lupe, 1983 & Entrada Sandstone & $\# 10$ \\
\hline 294 & Lupe, 1983 & Entrada Sandstone & $\# 146$ \\
\hline 295 & Lupe, 1983 & Entrada Sandstone & $\# 137$ \\
\hline 296 & Lupe, 1983 & Entrada Sandstone & $\# 56$ \\
\hline 297 & Lupe, 1983 & Entrada Sandstone & $\# 91$ \\
\hline 298 & Lupe, 1983 & Entrada Sandstone & $\# 81$ \\
\hline 299 & Lupe, 1983 & Entrada Sandstone & $\# 87$ \\
\hline 300 & Lupe, 1983 & Entrada Sandstone & $\# 226$ \\
\hline 301 & Lupe, 1983 & Entrada Sandstone & $\# 44$ \\
\hline 302 & Lupe, 1983 & Entrada Sandstone & $\# 212$ \\
\hline 303 & Lupe, 1983 & Entrada Sandstone & $\# 97$ \\
\hline 304 & Lupe, 1983 & Entrada Sandstone & $\# 268$ \\
\hline 305 & Rocky Mtn Assoc of Geologists & Entrada Sandstone & $\# 56$ \\
\hline 306 & Rocky Mtn Assoc of Geologists & Entrada Sandstone & \#53 Continental \\
\hline 307 & Rocky Mtn Assoc of Geologists & Entrada Sandstone & \#53 Skelly \\
\hline 308 & Rocky Mtn Assoc of Geologists & Entrada Sandstone & \#98 \\
\hline 309 & Rocky Mtn Assoc of Geologists & Entrada Sandstone & $\# 11$ \\
\hline 310 & Rocky Mtn Assoc of Geologists & Entrada Sandstone & $\# 12$ \\
\hline 311 & Rocky Mtn Assoc of Geologists & Entrada Sandstone & $\# 14$ \\
\hline 312 & Rocky Mtn Assoc of Geologists & Entrada Sandstone & $\# 16 \mathrm{~B}$ \\
\hline 313 & Rocky Mtn Assoc of Geologists & Entrada Sandstone & $\# 17 \mathrm{~B}$ \\
\hline 314 & Rocky Mtn Assoc of Geologists & Entrada Sandstone & $\# 19 \mathrm{~B}$ \\
\hline 315 & Rocky Mtn Assoc of Geologists & Entrada Sandstone & $\# 22$ \\
\hline
\end{tabular}


TABLE 7 (continued)

\begin{tabular}{|c|c|c|c|}
\hline $\begin{array}{l}\text { Section } \\
\text { No. }\end{array}$ & Author & Interval & $\begin{array}{l}\text { Their designation, } \\
\text { section name }\end{array}$ \\
\hline 316 & Rocky Mtn Assoc of Geologists & Entrada Sandstone & $\# 24$ \\
\hline 317 & Rocky Mtn Assoc of Geologists & Entrada Sandstone & $\# 31$ \\
\hline 318 & Rocky Mtn Assoc of Geologists & Entrada Sandstone & $\# 30$ \\
\hline 319 & Rocky Mtn Assoc of Geologists & Entrada Sandstone & $\# 29$ \\
\hline 320 & Rocky Mtn Assoc of Geologists & Entrada Sandstone & $\# 27$ \\
\hline 321 & Rocky Mtn Assoc of Geologists & Entrada Sandstone & $\# 28$ \\
\hline 322 & Rocky Mtn Assoc of Geologists & Entrada Sandstone & \#41 \\
\hline 323 & Rocky Mtn Assoc of Geologists & Entrada Sandstone & $\# 42$ \\
\hline 324 & Rocky Mtn Assoc of Geologists & Entrada Sandstone & \# 59 \\
\hline 325 & Rocky Mtn Assoc of Geologists & Entrada Sandstone & $\# 60$ \\
\hline 326 & Rocky Mtn Assoc of Geologists & Entrada Sandstone & $\# 62$ \\
\hline 327 & Rocky Mtn Assoc of Geologists & Entrada Sandstone & $\# 44$ \\
\hline 328 & Rocky Mtn Assoc of Geologists & Entrada Sandstone & $\# 96$ \\
\hline 329 & Rocky Mtn Assoc of Geologists & Entrada Sandstone & $\# 80$ \\
\hline 330 & Rocky Mtn Assoc of Geologists & Entrada Sandstone & $\# 81$ \\
\hline 331 & Rocky Mtn Assoc of Geologists & Entrada Sandstone & $\# 97$ \\
\hline 332 & Rocky Mtn Assoc of Geologists & Entrada Sandstone & \#98 \\
\hline 333 & Rocky Mtn Assoc of Geologists & Entrada Sandstone & \#99 \\
\hline 334 & Rocky Mtn Assoc of Geologists & Entrada Sandstone & $\# 87$ \\
\hline 335 & Rocky Mtn Assoc of Geologists & Entrada Sandstone & $\# 88$ \\
\hline 336 & Rocky Mtn Assoc of Geologists & Entrada Sandstone & $\# 89$ \\
\hline 337 & Rocky Mtn Assoc of Geologists & Entrada Sandstone & $\# 3$ \\
\hline 338 & Rocky Mtn Assoc of Geologists & Entrada Sandstone & $\# 7$ \\
\hline 339 & Rocky Mtn Assoc of Geologists & Entrada Sandstone & \#8B \\
\hline 340 & O’Sullivan, 1981 & Entrada Sandstone & 1-Salt Valley \\
\hline 341 & O'Sullivan, 1981 & Entrada Sandstone & 12-Square Park A \\
\hline 342 & O'Sullivan, 1981 & Entrada Sandstone & 5-Mine Draw \\
\hline 343 & O'Sullivan, 1981 & Entrada Sandstone & 6-Lost Spring A \\
\hline 344 & O'Sullivan, 1981 & Entrada Sandstone & 7-Lost Spring B \\
\hline 345 & O'Sullivan, 1981 & Entrada Sandstone & 8-Fish Seep Draw A \\
\hline 346 & O'Sullivan, 1981 & Entrada Sandstone & 9-Fish Seep Draw B \\
\hline 347 & O'Sullivan, 1981 & Entrada Sandstone & 10-Auger Spring A \\
\hline 348 & Smith et al., 1961 & Entrada Sandstone & Chama Basinlocal average \\
\hline 349 & Smith et al., 1961 & Entrada Sandstone & Chama Basinlocal average \\
\hline 350 & Smith et al., 1961 & Entrada Sandstone & Chama Basinlocal average \\
\hline 351 & Baldwin and Muehlberger, 1959 & Entrada Sandstone & $\# 5 B$ \\
\hline 352 & Baldwin and Muehlberger, 1959 & Entrada Sandstone & $\# 7$ \\
\hline 353 & Baldwin and Muehlberger, 1959 & Entrada Sandstone & $\# 8 B$ \\
\hline 354 & Baldwin and Muehlberger, 1959 & Entrada Sandstone & $\# 10 \mathrm{~A}$ \\
\hline 355 & Baldwin and Muehlberger, 1959 & Entrada Sandstone & $\# 12$ \\
\hline 356 & Baldwin and Muehlberger, 1959 & Entrada Sandstone & $\# 13$ \\
\hline 357 & Baldwin and Muehlberger, 1959 & Entrada Sandstone & $\# 14$ \\
\hline 358 & Baldwin and Muehlberger, 1959 & Entrada Sandstone & $\# 15$ \\
\hline 359 & Baldwin and Muehlberger, 1959 & Entrada Sandstone & \#17 \\
\hline 360 & Baldwin and Muehlberger, 1959 & Entrada Sandstone & $\# 22$ \\
\hline 361 & Baldwin and Muehlberger, 1959 & Entrada Sandstone & \#24 \\
\hline 362 & Baldwin and Muehlberger, 1959 & Entrada Sandstone & $\# 25$ \\
\hline 363 & Baldwin and Muehlberger, 1959 & Entrada Sandstone & $\# 27$ \\
\hline 364 & Baldwin and Muehlberger, 1959 & Entrada Sandstone & $\# 28$ \\
\hline 365 & Green 1974 & Entrada Sandstone & p. D5 \\
\hline 366 & Vincelette and Chittum, 1981 & Entrada Sandstone & Tenneco PAH-1 \\
\hline 367 & Vincelette and Chittum, 1981 & Entrada Sandstone & Sun Navajo 1 \\
\hline
\end{tabular}


TABLE 7 (continued)

\begin{tabular}{|c|c|c|c|}
\hline $\begin{array}{l}\text { Section } \\
\text { No. }\end{array}$ & Author & Interval & $\begin{array}{l}\text { Their designation, } \\
\text { section name }\end{array}$ \\
\hline 368 & Vincelette and Chittum, 1981 & Entrada Sandstone & Sun Navajo Lands 1 \\
\hline 369 & Vincelette and Chittum, 1981 & Entrada Sandstone & Sun Federal 1 \\
\hline 370 & Vincelette and Chittum, 1981 & Entrada Sandstone & Union Caldwell Ranch 1 \\
\hline 371 & Vincelette and Chittum, 1981 & Entrada Sandstone & Pan Am C-USA-1 \\
\hline 372 & Vincelette and Chittum, 1981 & Entrada Sandstone & Magnolia Hutchinson 1 \\
\hline 373 & Vincelette and Chittum, 1981 & Entrada Sandstone & Brinkerhoff Cabezon-1 \\
\hline 374 & Wright and Dickey, 1979 & Entrada Sandstone & 53-Main Elk Creek \\
\hline 375 & Wright and Dickey, 1979 & Entrada Sandstone & 72-Flag Creek \\
\hline 376 & Wright and Dickey, 1979 & Entrada Sandstone & 85-Riland-Midnight Mine \\
\hline 377 & Wright and Dickey, 1979 & Entrada Sandstone & 86-Marion Creek \\
\hline 378 & Wright and Dickey, 1979 & Entrada Sandstone & 79 -King Creek \\
\hline 379 & Wright et al., 1979 & Entrada Sandstone & 52 - Sandy Mine \\
\hline 380 & Wright et al., 1979 & Entrada Sandstone & 68 - Puertecito \\
\hline 381 & Wright et al., 1979 & Entrada Sandstone & 57 -Correo \\
\hline 382 & Wright and Dickey, 1979 & Entrada Sandstone & 55-Galisteo Creek \\
\hline 383 & Wright and Dickey, 1979 & Entrada Sandstone & 66 - Mesa Alta \\
\hline 384 & Wright and Dickey, 1979 & Entrada Sandstone & 67-Blakey's San Cristobal Ranch \\
\hline 385 & Wright and Dickey, 1979 & Entrada Sandstone & 58 - Ganado \\
\hline 386 & Pipiringos, Hail and Izett & Entrada Sandstone & B--Radium SW \\
\hline 387 & Pipiringos, Hail and Izett & Entrada Sandstone & C-Radium SE \\
\hline 388 & Wright and Dickey, 1979 & Entrada Sandstone & $\mathrm{D}$-Kremmling \\
\hline 389 & Wright and Dickey, 1979 & Entrada Sandstone & F-Snowshoe Ranch \\
\hline 390 & Wright and Dickey, 1979 & Entrada Sandstone & G-Tyler Mountain \\
\hline 391 & Wright and Dickey, 1979 & Entrada Sandstone & H-McMahon Reservoir \\
\hline 392 & Wright and Dickey, 1979 & Entrada Sandstone & J-Frantz Creek \\
\hline 393 & Muehlberger, 1967 & Entrada Sandstone & $\mathrm{CC}$--Chaves Canyon \\
\hline 394 & Pipiringos, 1968 & Entrada Sandstone & \#51 - 2 - 2 \\
\hline 395 & Pipiringos, 1968 & Entrada Sandstone & $\# 42$ \\
\hline 396 & Pipiringos, 1968 & Entrada Sandstone & $\# 44$ \\
\hline 397 & Pipiringos, 1968 & Entrada Sandstone & $\# 40$ \\
\hline 398 & Pipiringos, 1968 & Entrada Sandstone & $\# 39$ \\
\hline 399 & Pipiringos, 1968 & Entrada Sandstone & $\# 37$ \\
\hline 400 & Pipiringos, 1968 & Entrada Sandstone & $\# 38$ \\
\hline 401 & Pipiringos, 1968 & Entrada Sandstone & $\# 35$ \\
\hline 402 & Pipiringos, 1968 & Entrada Sandstone & $\# 34$ \\
\hline 403 & Pipiringos, 1968 & Entrada Sandstone & $\# 33$ \\
\hline 404 & Pipiringos, 1968 & Entrada Sandstone & $\# 56$ \\
\hline 405 & Pipiringos, 1968 & Entrada Sandstone & $\# 32$ \\
\hline 406 & Pipiringos, 1968 & Entrada Sandstone & $\# 31$ \\
\hline 407 & Pipiringos, 1968 & Entrada Sandstone & $\# 30$ \\
\hline 409 & Pipiringos, 1968 & Entrada Sandstone & $\# 28$ \\
\hline 409 & Pipiringos, 1968 & Entrada Sandstone & $\# 10$ \\
\hline 410 & Lucas et al., 1985 & Entrada Sandstone & $\# 1$ \\
\hline 411 & Lucas et al., 1985 & Entrada Sandstone & $\# 1$ \\
\hline 412 & Lucas et al., 1985 & Entrada Sandstone & $\# 4$ \\
\hline 413 & Lucas et al., 1985 & Entrada Sandstone & $\# 8$ \\
\hline 414 & Lucas et al., 1985 & Entrada Sandstone & $\# 9$ \\
\hline 415 & Lucas et al., 1985 & Entrada Sandstone & $\# 10$ \\
\hline 416 & Lucas et al., 1985 & Entrada Sandstone & $\# 11$ \\
\hline 417 & Lucas et al., 1985 & Entrada Sandstone & $\# 12$ \\
\hline 418 & Lucas et al., 1985 & Entrada Sandstone & $\# 13$ \\
\hline 419 & Lucas et al., 1985 & Entrada Sandstone & $\# 15$ \\
\hline 420 & Lucas et al., 1985 & Entrada Sandstone & \#18 \\
\hline
\end{tabular}


TABLE 7 (continued)

\begin{tabular}{|c|c|c|c|}
\hline $\begin{array}{l}\text { Section } \\
\text { No. }\end{array}$ & Author & Interval & $\begin{array}{l}\text { Their designation, } \\
\text { section name }\end{array}$ \\
\hline 421 & Lucas et al., 1985 & Entrada Sandstone & $\# 28$ \\
\hline 422 & Lucas et al., 1985 & Entrada Sandstone & $\# 36$ \\
\hline 423 & Lucas et al., 1985 & Entrada Sandstone & $\# 43$ \\
\hline 424 & Lucas et al., 1985 & Entrads Sandstone & $\# 44$ \\
\hline 425 & Lucas et al., 1985 & Entrada Sandstone & $\# 45$ \\
\hline 426 & Lucas et al., 1985 & Entrada Sandstone & $\# 47$ \\
\hline 427 & Lucas et al., 1985 & Entrada Sandstone & $\# 49$ \\
\hline 428 & Lucas et al., 1985 & Entrada Sandstone & $\# 51$ \\
\hline 429 & Lucas et al., 1985 & Entrada Sandstone & $\# 60$ \\
\hline 430 & Lucas et al., 1985 & Entrada Sandstone & $\# 61$ \\
\hline 431 & Lucas et al., 1985 & Entrada Sandstone & $\# 62$ \\
\hline 432 & Lucas et al., 1985 & Entrada Sandstone & $\# 63$ \\
\hline 433 & Lucas et al., 1985 & Entrada Sandstone & \#64 \\
\hline 434 & Mankin, 1958 & Entrada Sandstone & 57-3 San Agustin \\
\hline 435 & Mankin, 1958 & Entrada Sandstone & 57-4 Trujillo Hill \\
\hline 436 & Mankin, 1958 & Entrada Sandstone & 57-5 Sabinoso Canyon \\
\hline 437 & Mankin, 1958 & Entrada Sandstone & 57-8 Burro Canyon \\
\hline 438 & Mankin, 1958 & Entrada Sandstone & 56-2 Mitchell Ranch \\
\hline 439 & Mankin, 1958 & Entrada Sandstone & 57-9 Gallegos Ranch \\
\hline 440 & Mankin, 1958 & Entrada Sandstone & $57-10$ San Jon \\
\hline 441 & Bachman, 1953 & Entrada Sandstone & $\# 5$ \\
\hline 442 & Wanek, 1962 & Entrada Sandstone & 1-Lacinta Creek \\
\hline 443 & Wanek, 1962 & Entrada Sandstone & $\# 5$ \\
\hline 444 & Wanek, 1962 & Entrada Sandstone & 4-Montoya \\
\hline 445 & Wanek, 1962 & Entrada Sandstone & 3-Bell Peak \\
\hline 446 & Wanek, 1962 & Entrada Sandstone & 2-SE Huerfano Mesa \\
\hline 447 & Wood et al., 1953 & Entrada Sandstone & 12 -Cora B. Moore \#1 \\
\hline 448 & Wood et al., 1953 & Entrada Sandstone & $11-$ Sauble \#1-A \\
\hline 449 & Wood et al., 1953 & Entrada Sandstone & 9-Herrera \#1 \\
\hline 450 & Wood et al., 1953 & Entrada Sandstone & 8-Rito Del Plano \# 1 \\
\hline 451 & Wood et al., 1953 & Entrada Sandstone & 7 -Chico \#1 \\
\hline 452 & Wood et al., 1953 & Entrada Sandstone & 2-Floersheim \#1 \\
\hline 453 & Smith, 1951 & Entrada Sandstone & \\
\hline 454 & Dobrovolny and Summerson, 1946 & Entrada Sandstone & \#6 \\
\hline 455 & Dobrovolny and Summerson, 1946 & Entrada Sandstone & \#7 \\
\hline 456 & Dobrovolny and Summerson, 1946 & Entrada Sandstone & \#5 \\
\hline 457 & Dobrovolny and Summerson, 1946 & Entrada Sandstone & \#3 \\
\hline 458 & Dobrovolny and Summerson, 1946 & Entrada Sandstone & \#4 \\
\hline 459 & Dobrovolny and Summerson, 1946 & Entrada Sandstone & \#8 \\
\hline 460 & Dobrovolny and Summerson, 1946 & Entrada Sandstone & \#9 \\
\hline 461 & Dobrovolny and Summerson, 1946 & Entrada Sandstone & $\# 10$ \\
\hline 462 & Savela, 1977 & Entrada Sandstone & $\# 2$ \\
\hline 463 & Trauger and Bushman, 1964 & Entrada Sandstone & p. 22 \\
\hline 464 & Knowles et al., 1982 & Entrada Sandstone & Regional pinchout of Entrada \\
\hline 465 & Turner - Peterson (unpubl. data 1983) & Entrada Sandstone & Toadlena \\
\hline 466 & Huffman and Kirk (unpubl. data 1980) & Entrada Sandstone & Todilto Park/Lake Asaryl \\
\hline 467 & Saucier, 1967 & Entrada Sandstone & Black Creek Valley \\
\hline 468 & Saucier, 1967 & Entrada Sandstone & Window Rock \\
\hline 469 & Saucier, 1967 & Entrada Sandstone & Oak Springs Gap \\
\hline 470 & Saucier, 1967 & Entrada Sandstone & Cheechilgeetho \\
\hline 471 & Saucier, 1967 & Entrada Sandstone & Beal-Miller \\
\hline 472 & Saucier, 1967 & Entrada Sandstone & Gallup \\
\hline
\end{tabular}


TABLE 7 (continued)

\begin{tabular}{|c|c|c|c|}
\hline $\begin{array}{l}\text { Section } \\
\text { No. }\end{array}$ & Author & Interval & $\begin{array}{l}\text { Their designation, } \\
\text { section name }\end{array}$ \\
\hline 473 & Saucier, 1967 & Entrada Sandstone & Pyramid Peak \\
\hline 474 & Condon and Peterson, $1986(\mathrm{~K})$ & Entrada Sandstone & Fort Defiance \\
\hline 475 & Condon and Peterson, $1986(\mathrm{~K})$ & Entrada Sandstone & Haystack Butte \\
\hline 476 & Condon unpubl. data, 1980 & Entrada Sandstone & Pipeline Road \\
\hline 477 & Condon unpubl. data, 1982 & Entrada Sandstone & Lupton \\
\hline 478 & Anderson, 1983 & Entrada Sandstone & Taaiyalone Mesa \\
\hline 479 & Harshbarger et al., 1957 & Entrada Sandstone & Fort Wingate \\
\hline 480 & Kirk et al. (unpubl. data, 1980) & Entrada Sandstone & Pinedale $\mathrm{W}$ and $\mathrm{W}$ \\
\hline 481 & Huffman and Kirk (unpubl. data, 1980) & Entrada Sandstone & Coolidge Quarry \\
\hline 482 & Robertson (unpubl. data, 1983) & Entrada Sandstone & Thorean E \\
\hline 483 & PI & Page SS, Entrada SS & \#1 Unit the California Co. \\
\hline 484 & PI & Page SS, Entrada SS & \#2 Unit the California Co. \\
\hline 485 & PI & Page SS, Entrada SS & \# 1. S. Upper Valley Tennecy Oil \\
\hline 486 & PI & Page SS, Entrada SS & \# 1 Lyons-Federal Sun Oil Co. \\
\hline 487 & PI & Page SS, Entrada SS & \#2 Unit Great Western Drilling \\
\hline 488 & PI & Page SS, Entrada SS & \#1 Tibbet Cany. Tenneco Oil Co \\
\hline 489 & PI & Page SS, Entrada SS & \#1-16 State Romex Corp. \\
\hline 490 & PI & Page SS, Entrada SS & \# 1 Unit Shell Oil Co. \\
\hline 491 & PI & Page Sandstone & \# 1 Judd Hollow Unit Union Oil \\
\hline 492 & PI & Entrada Sandstone & \#123 Second Mesa \\
\hline 493 & PI & Entrada Sandstone & \#1 USA-Tropic Tenneco Oil Co. \\
\hline 494 & PI & Entrada Sandstone & \#1 Forest et al., Forest Oil \\
\hline 495 & PI & Entrada Sandstone & $\begin{array}{l}\# 41-27 \text { Johns Valley Unit, } \\
\text { Tidewater Oil Co. }\end{array}$ \\
\hline 496 & PI & Entrada Sandstone & \#1 Unit the California Co. \\
\hline 497 & PI & Entrada Sandstone & $\# 1-X$ North Creek Tenneco Oil \\
\hline 498 & PI & Entrada Sandstone & $\# 1$ - Griffin Point Unit Tenneco Oil \\
\hline 499 & Peterson (unpubl. data) & Page Sandstone & Rawhide Cave \\
\hline 500 & Peterson (unpubl. data) & Page Sandstone & Sixtymile Point -1 \\
\hline 501 & Peterson (unpubl. data) & Page Sandstone & Sixtymile Point -2 \\
\hline 502 & Peterson (unpubl. data) & Page Sandstone & Sooner Wash \\
\hline 503 & Peterson (unpubl. data) & Page Sandstone & Soda Spring \\
\hline 504 & Peterson (unpubl. data) & Page Sandstone & Thousand Pockets-1 \\
\hline 505 & Peterson (unpubl. data) & Page Sandstone & Red Canyon \\
\hline 506 & Peterson (unpubl. data) & Page Sandstone & Park Ridge \\
\hline 507 & Peterson (unpubl. data) & Page Sandstone & Lion Mountain \\
\hline 508 & Peterson (unpubl. data) & Page Sandstone & Averett Hollow \\
\hline 509 & Peterson (unpubl. data) & Page Sandstone & Jacobs Tanks \\
\hline 510 & Peterson (unpubl. data) & Page Sandstone & Warm Creek Mouth E-3 \\
\hline 511 & Peterson (unpubl. data) & Page Sandstone & Warm Creek Mouth S \\
\hline 512 & Peterson (unpubl. data) & Page Sandstone & Warm Creek Mouth W \\
\hline 513 & Peterson (unpubl. data) & Page Sandstone & Labyrinth Canyon $\mathbf{E}$ \\
\hline 514 & Peterson (unpubl. data) & Page Sandstone & Gregory Butte S \\
\hline 515 & Peterson (unpubl. data) & Page Sandstone & Big Spencer Flats \\
\hline 516 & Peterson (unpubl. data) & Page Sandstone & The Box \\
\hline 517 & Peterson (unpubl. data) & Page Sandstone & Boulder S \\
\hline 518 & Peterson (unpubl. data) & Page Sandstone & Cons Knoll \\
\hline 519 & Peterson (unpubl. data) & Page Sandstone & Chokecherry Creek \\
\hline 520 & Peterson (unpubl. data) & Page Sandstone & Capitol Reef Waterfall \\
\hline 521 & Peterson (unpubl. data) & Page Sandstone & Escalante $\mathrm{E}$ \\
\hline 522 & Peterson (unpubl. data) & Page Sandstone & Haymaker Bench \\
\hline 523 & Peterson (unpubl. data) & Page Sandstone & Halls Creek Canyon \\
\hline 524 & Peterson (unpubl. data) & Page Sandstone & West Ranch Creek \\
\hline
\end{tabular}


TABLE 7 (continued)

\begin{tabular}{|c|c|c|c|}
\hline $\begin{array}{l}\text { Section } \\
\text { No. }\end{array}$ & Author & Interval & $\begin{array}{l}\text { Their designation, } \\
\text { section name }\end{array}$ \\
\hline 525 & Peterson (unpubl. data) & Page Sandstone & Kaibito NW - 2 \\
\hline 526 & Peterson (unpubl. data) & Page Sandstone & Egypt \\
\hline 527 & Peterson (unpubl. data) & Page Sandstone & Cleopatra's Needle \\
\hline 528 & Peterson (unpubl. data) & Page Sandstone & Driftwood Canyon \\
\hline 529 & Peterson (unpubl. data) & Page Sandstone & Early Weed Bench E \\
\hline 530 & Peterson (unpubl. data) & Page Sandstone & Escalante Viewpoint \\
\hline 531 & Peterson (unpubl. data) & Page Sandstone & Gregory Butte S \\
\hline 532 & Peterson (unpubl. data) & Page Sandstone & Boulder N \\
\hline 533 & Peterson (unpubl. data) & Page Sandstone & Cottonwood Canyon \\
\hline 534 & Peterson (unpubl. data) & Page Sandstone & Cottonwood Gulch \\
\hline 535 & Peterson (unpubl. data) & Page Sandstone & Capitol Wash \\
\hline 536 & Peterson (unpubl. data) & Page Sandstone & Hole-in-the-Rock NW \\
\hline 537 & Peterson (unpubl. data) & Page Sandstone & Bridger Point \\
\hline 538 & Peterson (unpubl. data) & Page Sandstone & Cedar Mountain S \\
\hline 539 & Peterson (unpubl. data) & Page SS, Entrada SS & Dangling Rope Canyon \\
\hline 540 & Peterson (unpubl. data) & Page Sandstone & Owl Bridge \\
\hline 541 & Peterson (unpubl. data) & Page Sandstone & North Wash \\
\hline 542 & Peterson (unpubl. data) & Page Sandstone & Labyrinth Canyon W \\
\hline 543 & Peterson (unpubl. data) & Page Sandstone & North Wash \\
\hline 544 & Peterson (unpubl. data) & Page SS, Entrada SS & Muley Twist Canyon Mouth \\
\hline 545 & Peterson (unpubl. data) & Page Sandstone & Poules Tanks \\
\hline 546 & Peterson (unpubl. data) & Page Sandstone & Page S \\
\hline 547 & Peterson (unpubl. data) & Page Sandstone & Oak Creek \\
\hline 548 & Peterson (unpubl. data) & Page Sandstone & Middle Rock Creek \\
\hline 549 & Peterson (unpubl. data) & Page Sandstone & $1-70$ and San Rafael Swell E \\
\hline 550 & Peterson (unpubl. data) & Page Sandstone & $1-70$ and San Rafael Swell $w$ \\
\hline 551 & Peterson (unpubl. data) & Page Sandstone & Gruss Knoll \\
\hline 552 & Peterson (unpubl. data) & Page Sandstone & Deer Point \\
\hline 553 & Peterson (unpubl. data) & Page Sandstone & Buckhorn Wash \\
\hline 554 & Peterson (unpubl. data) & Page Sandstone & Burr Point \\
\hline 555 & Peterson (unpubl. data) & Page Sandstone & Burr Trail \\
\hline 556 & Peterson (unpubl. data) & Page Sandstone & Little Egypt \\
\hline 557 & Peterson (unpubl. data) & Page Sandstone & Mt. Hillers S \\
\hline 558 & Peterson (unpubl. data) & Page SS, Entrada SS & The Post \\
\hline 559 & Peterson (unpubl. data) & Page Sandstone & Rushbeds Road \\
\hline 560 & Peterson (unpubl. data) & Page SS, Entrada SS & The Post $\mathbf{S}$ \\
\hline 561 & Peterson (unpubl. data) & Page Sandstone & Coppermine \\
\hline 562 & Peterson (unpubl. data) & Page Sandstone & Face Canyon $\mathbf{E}$ \\
\hline 563 & Peterson (unpubl. data) & Page Sandstone & Cedar Mountain \\
\hline 564 & Peterson (unpubl. data) & Page Sandstone & Leche-e Rock NE \\
\hline 565 & Peterson (unpubl. data) & Page Sandstone & Kaibito NW-1 \\
\hline 566 & Peterson (unpubl. data) & Page Sandstone & Sooner Slide N \\
\hline 567 & Peterson (unpubl. data) & Page Sandstone & Fortymile Gulch \\
\hline 568 & Peterson (unpubl. data) & Page Sandstone & Fortymile Ridge \\
\hline 569 & Peterson (unpubl. data) & Page Sandstone & Mount Ogden \\
\hline 570 & Peterson (unpubl. data) & Entrada Sandstone & Leche-e Rock \\
\hline 571 & Peterson (unpubl. data) & Entrada Sandstone & Hackberry Canyon \\
\hline 572 & Peterson (unpubl. data) & Entrada Sandstone & Navajo Valley W \\
\hline 573 & Peterson (unpubl. data) & Entrada Sandstone & Big Hollow Wash \\
\hline 574 & Peterson (unpubl. data) & Entrada Sandstone & East Cove \\
\hline 575 & Peterson (unpubl. data) & Entrada Sandstone & Fortynine Mile Point \\
\hline 576 & Peterson (unpubl. data) & Entrada Sandstone & Spring Canyon \\
\hline
\end{tabular}


TABLE 7 (continued)

\begin{tabular}{|c|c|c|c|}
\hline $\begin{array}{l}\text { Section } \\
\text { No. }\end{array}$ & Author & Interval & $\begin{array}{l}\text { Their designation, } \\
\text { section name }\end{array}$ \\
\hline 577 & Peterson (unpubl. data) & Entrada Sandstone & Kodachrome Flats \\
\hline 578 & Peterson (unpubl. data) & Entrada Sandstone & Thursday Canyon \\
\hline 579 & Peterson (unpubl. data) & Entrada Sandstone & Coyote Creek \\
\hline 580 & Peterson (unpubl. data) & Entrada Sandstone & Little Egypt \\
\hline 581 & Peterson (unpubl. data) & Entrada Sandstone & Tenderfoot Mesa \\
\hline 582 & Peterson (unpubl. data) & Entrada Sandstone & Red Canyon \\
\hline 583 & Peterson (unpubl. data) & Entrada Sandstone & West Canyon \\
\hline 584 & Peterson (unpubl. data) & Entrada Sandstone & Tsezi \\
\hline 585 & Peterson (unpubl. data) & Entrada Sandstone & Dry Rock Creek SE \\
\hline 586 & Peterson (unpubl. data) & Entrada Sandstone & Middle Rock Creek Canyon \\
\hline 587 & Peterson (unpubl. data) & Entrada Sandstone & Fortymile Point \\
\hline 588 & Peterson (unpubl. data) & Entrada Sandstone & Rock Creek W \\
\hline 589 & Peterson (unpubl. data) & Entrada Sandstone & Mountain Sheep Canyon \\
\hline 590 & Peterson (unpubl. data) & Entrada Sandstone & Harvey's Fear \\
\hline 591 & Peterson (unpubl. data) & Entrada Sandstone & Teasdale S \\
\hline 592 & Peterson (unpubl. data) & Entrada Sandstone & Cumming's Mesa E Fingers \\
\hline 593 & Peterson (unpubl. data) & Entrada Sandstone & Steamboat E \\
\hline 594 & Peterson (unpubl. data) & Entrada Sandstone & Star Mountain \\
\hline 595 & Peterson (unpubl. data) & Entrada Sandstone & Klethla Valley \\
\hline 596 & Peterson (unpubl. data) & Entrada Sandstone & Lohali Point \\
\hline 597 & Peterson (unpubl. data) & Entrada Sandstone & Castle Rock \\
\hline 598 & Peterson (unpubl. data) & Entrada Sandstone & Cummings Mesa W Fingers \\
\hline 599 & Peterson (unpubl. data) & Entrada Sandstone & Cow Springs \\
\hline 600 & Peterson (unpubl. data) & Entrada Sandstone & Square Butte \\
\hline 601 & Peterson (unpubl. data) & Entrada Sandstone & Tsai Skizzie \\
\hline 602 & Peterson (unpubl. data) & Entrada Sandstone & Tenmile Wash \\
\hline 603 & Peterson (unpubl. data) & Entrada Sandstone & Wolcott \\
\hline 604 & Peterson (unpubl. data) & Entrada Sandstone & Cedar Mountain \\
\hline 605 & Peterson (unpubl. data) & Entrada Sandstone & Little Bull Valley \\
\hline 606 & Read et al., 1949 & Entrada Sandstone & Trail Creek \\
\hline 607 & Read et al., 1949 & Entrada Sandstone & Davis Creek \\
\hline 608 & Read et al., 1949 & Entrada Sandstone & Sand Creek \\
\hline 609 & Read et al., 1949 & Entrada Sandstone & Weminuche Creek SW \\
\hline 610 & Read et al., 1949 & Entrada Sandstone & Tres Piedras Ranch \\
\hline 611 & Read et al., 1949 & Entrada Sandstone & Elk Creek \\
\hline 612 & Read et al., 1949 & Entrada Sandstone & Indian Creek-Dudley Creek \\
\hline 613 & Wood et al., 1948 & Entrada Sandstone & \# 1 Sullenberger Wirt Franklin et al. \\
\hline 614 & Wood et al., 1948 & Entrada Sandstone & Crowley \#1 Phillips Petrol. Co. \\
\hline 615 & Craig et al., 1959 & Entrada Sandstone & Bitter Springs Seep \\
\hline 616 & Craig et al., 1959 & Entrada Sandstone & Thoreau \\
\hline 617 & Craig et al., 1959 (P) & Entrada Sandstone & Toadlona \\
\hline 618 & Craig et al., 1959 (P) & Entrada Sandstone & Todilto \\
\hline 619 & Craig et al., 1959 (P) & Entrada Sandstone & Mesa Gigante \\
\hline 620 & Craig et al., 1959 (P) & Entrada Sandstone & Oak Spring Wash \\
\hline 621 & Craig et al., 1959 (P) & Entrada Sandstone & Sanostee Wash \\
\hline 622 & Craig et al., 1959 & Entrada Sandstone & Ghost Ranch \\
\hline 623 & Craig et al., 1959 (P) & Entrada Sandstone & Haystack Butte \\
\hline 624 & Craig et al., 1959 & Entrada Sandstone & Las Vegas \\
\hline 625 & Craig et al., 1959 (P) & Entrada Sandstone & Cuchillo Arroyo \\
\hline 626 & Craig et al., 1959 & Entrada Sandstone & Dry Cimmaron \\
\hline 627 & Craig et al., 1959 & Entrada Sandstone & Fort Defiance \\
\hline 628 & Craig et al., 1959 (P) & Entrada Sandstone & Marsh Pass \\
\hline
\end{tabular}


TABLE 7 (continued)

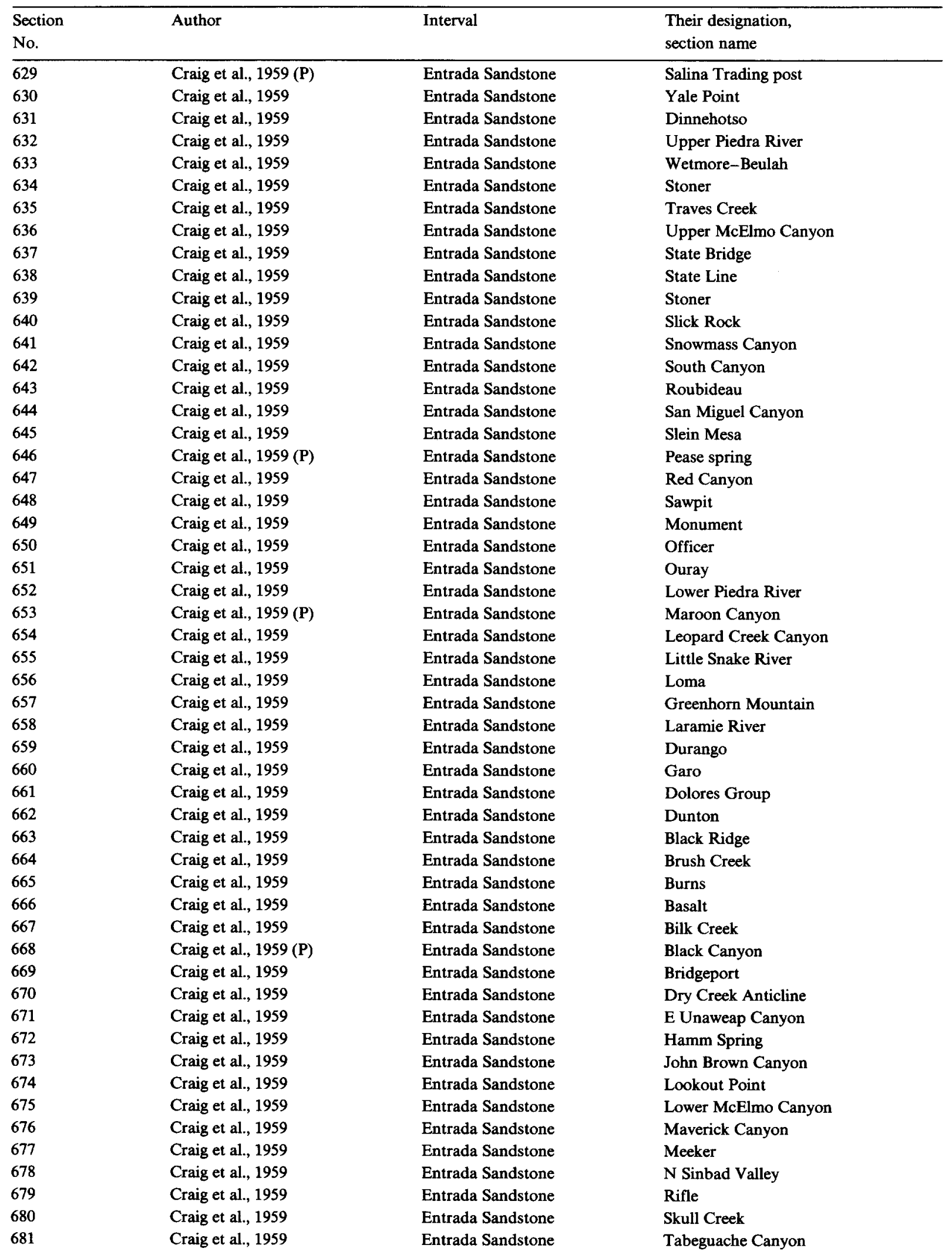


TABLE 7 (continued)

\begin{tabular}{|c|c|c|c|}
\hline $\begin{array}{l}\text { Section } \\
\text { No. }\end{array}$ & Author & Interval & $\begin{array}{l}\text { Their designation, } \\
\text { section name }\end{array}$ \\
\hline 682 & Craig et al., 1959 & Entrada Sandstone & Tenderfoot Mesa \\
\hline 683 & Craig et al., 1959 & Entrada Sandstone & Vermillion Creek \\
\hline 684 & Weimer, 1981 & Entrada Sandstone & Whitlock Swanson 1-A \\
\hline 685 & Hansen, 1968 & Entrada Sandstone & Pitts Meadow W \\
\hline 686 & Hansen, 1968 & Entrada Sandstone & Smith Fork \\
\hline 687 & Langenheim, $1957(P)$ & Entrada Sandstone & Schofield Park \\
\hline 688 & Langenheim, $1957(\mathrm{P})$ & Entrada Sandstone & Thompson Creek \\
\hline 689 & Langenheim, 1957 & Entrada Sandstone & Marion Creek \\
\hline 690 & Condon and Huffman, 1984 & Entrada Sandstone & Beclabito Dome \\
\hline 691 & Hansen, 1971 & Entrada Sandstone & Grizzly Ridge \\
\hline 692 & Bryant, 1979 & Entrada Sandstone & Baldy Mountain \\
\hline 693 & Bryant, 1979 & Entrada Sandstone & E Snowmass Creek \\
\hline 694 & McFall, 1955 & Entrada Sandstone & Burr Trail \\
\hline 695 & McFall, 1955 & Entrada Sandstone & Muddy River \\
\hline 696 & Strobell, 1956 & Entrada Sandstone & Red Mesa \\
\hline 697 & Strobell, 1956 & Entrada Sandstone & Sunnyside Mine \\
\hline 698 & Strobell, 1956 & Entrada Sandstone & Syracuse Mine \\
\hline 699 & $\begin{array}{l}\text { Huffman and Turner-Peterson } \\
\text { (unpubl. data) }\end{array}$ & Entrada Sandstone & Beclabito Dome \\
\hline 700 & Santos and Moench, 1971 & Entrada Sandstone & Unnamed \\
\hline 701 & Santos and Moench, 1971 & Entrada Sandstone & Unnamed \\
\hline 702 & Santos, 1975 & Entrada Sandstone & Drill Hole C \\
\hline 703 & Santos, 1975 & Entrada Sandstone & Drill Hole D \\
\hline 704 & Santos, 1975 & Entrada Sandstone & Drill Hole E \\
\hline 705 & Condon, 1985A & Entrada Sandstone & 11 - Todilto Park \\
\hline 706 & Condon, 1985A & Entrada Sandstone & $12-$ Navajo \\
\hline 707 & Condon, 1985A & Entrada Sandstone & 13-Twin Buttes Wash \\
\hline 708 & Condon, 1985A & Entrada Sandstone & 15-Bowman Park \\
\hline 709 & Condon, 1985B & Entrada Sandstone & 1-Navajo Church \\
\hline 710 & Condon, 1985B & Entrada Sandstone & 2-Midget Mesa \\
\hline 711 & Condon, 1985B & Entrada Sandstone & 3-Pinedale Monocline \\
\hline 712 & Condon, 1985B & Entrada Sandstone & 4-E Thoreau \\
\hline 713 & Condon, 1985B & Entrada Sandstone & 5-Andrews Ranch \\
\hline 714 & Condon, 1985B & Entrada Sandstone & 6-Haystack Mountain \\
\hline 715 & Wright, 1973 & Entrada Sandstone & 12-Vinceant Ranch \\
\hline 716 & Wright, 1973 & Entrada Sandstone & 13-Alcova \\
\hline 717 & Wright, 1973 & Entrada Sandstone & 4-Rapid City \\
\hline 718 & Wright, 1973 & Entrada Sandstone & 6-Newcastle \\
\hline 719 & Rautman, 1975 & Entrada Sandstone & 3-Whaley Canyon \\
\hline 720 & Rautman, 1975 & Entrada Sandstone & 4-Minnekahta \\
\hline 721 & Rautman, 1975 & Entrada Sandstone & 7 -Stockade Beaver Creek \\
\hline 722 & Rautman, 1975 & Entrada Sandstone & 15-Farthing \\
\hline 723 & Rautman, 1975 & Entrada Sandstone & $16-$ Red Mountain \\
\hline 724 & Rautman, 1975 & Entrada Sandstone & 25-Dallas Anticline \\
\hline 725 & Finch and Wright, 1983 & Entrada Sandstone & 29-Labrier Butte \\
\hline 726 & Finch and Wright, 1983 & Entrada Sandstone & $28-W$ Fork, S Picket House Draw \\
\hline 727 & Love et al., 1945 & Entrada Sandstone & $21-$ Kirk \#1 \\
\hline 728 & Love et al., 1945 & Entrada Sandstone & 20-Hailey \\
\hline 729 & Love et al., 1945 & Entrada Sandstone & 19-Noble Ranch \\
\hline 730 & Love et al., 1945 & Entrada Sandstone & 20-Dutton Ranch \\
\hline 731 & Love et al., 1945 & Entrada Sandstone & $25-$ No. C-2 Well \\
\hline 732 & Love et al., 1945 & Entrada Sandstone & 24-Conant Creek \\
\hline 733 & Vanderwilt, 1937 & Entrada Sandstone & Copper Creek \\
\hline
\end{tabular}


TABLE 7 (continued)

\begin{tabular}{llll}
\hline $\begin{array}{l}\text { Section } \\
\text { No. }\end{array}$ & Author & Interval & $\begin{array}{l}\text { Their designation, } \\
\text { section name }\end{array}$ \\
\hline 734 & Ward, 1957 & Entrada Sandstone & Michigan River \\
735 & Ward, 1957 & Entrada Sandstone & Michigan River \\
736 & Grote, 1957 & Entrada Sandstone & Battleship Field \\
737 & York, 1957 & Entrada Sandstone & Muddy Creek \\
738 & Gilluly and Reeside, 1928 & Entrada Sandstone & Entrada Point \\
739 & Gilluly and Reeside, 1928 & Entrada Sandstone & Starvation Point \\
740 & Gilluly and Reeside, 1928 & Entrada Sandstone & Muddy River \\
741 & Gilluly and Reeside, 1928 & Entrada Sandstone & Cottonwood Springs Draw \\
742 & Trimble and Doelling, 1978 & Entrada Sandstone & The Squeeze S. \\
743 & Trimble and Doelling, 1978 & Entrada Sandstone & The Squeeze \\
744 & Peterson (unpubl. data) & Entrada Sandstone & Tergeson Flats \\
\hline
\end{tabular}

\section{References}

Agatston, R.S., 1954. Pennsylvanian and Lower Permian of northern and eastern Wyoming. Bull. Am. Assoc. Pet. Geol., 38: 508-583.

Anderson, D.J., 1983. What is the Zuni Sandstone today-100 years after Dutton? A discussion and review of Jurassic stratigraphy in west-central New Mexico. N.M. Bur. Mines Miner. Resour., Open File Rep. OF-174, 34 p.

Averitt, P., 1962. Geology and coal resources of the Cedar Mountain quadrangle, Iron County, Utah. U.S. Geol. Surv., Prof. Pap., 389: 72 pp.

Baars, D.L., 1962. Permian system of Colorado Plateau. Bull. Am. Assoc. Pet. Geol., 46: 149-218.

Baars, D.L. and Seager, W.R., 1970. Stratigraphic control of petroleum in White Rim Sandstone (Permian) in and near Canyonlands National Park, Utah. Bull. Am. Assoc. Pet. Geol., 54: 709-718.

Bachman, G.O., 1953. Geology of a part of northwestern Mora County, New Mexico. U.S. Geol. Surv., Oil and Gas Invest. Map OM-137.

Baker, A.A., 1946. Geology of the Green River Desert-Cataract Canyon region, Emery, Wayne, and Garfield Counties, Utah. U.S. Geol. Surv. Bull., 951: 122 pp.

Baker, A.A., Dane, C.H. and Reeside Jr., J.B., 1936. Correlation of the Jurassic formations of parts of Utah, Arizona, New Mexico, and Colorado. U.S. Geol. Surv., Prof. Pap., 183: $66 \mathrm{pp}$.

Baldwin, B. and Muehlberger, W.R., 1959. Geologic studies of Union County, New Mexico. N.M. State Bur. Mines Miner. Resour. Bull., 63: 171 pp.

Beaumont, E.C. and Dixon, G.G., 1965. Geology of the Kayenta and Chilchinbito quadrangles, Navajo County, Arizona. U.S. Geol. Surv. Bull., 1202-A: A1-A28.

Bell III, H. and Post, E.V., 1971. Geology of the Flint Hill quadrangle, Fall River County, South Dakota. U.S. Geol. Surv. Bull., 1053-M: 505-586.
Bilodeau, W.L. and Keith, S.B., 1986. Lower Jurassic Navajo-Aztec-equivalent sandstones in southern Arizona and their paleogeographic significance. Bull. Am. Assoc. Pet. Geol., 70: 690-701.

Bissell, H.J., 1969. Permian and Lower Triassic transition from the shelf to basin (Grand Canyon, Arizona to Spring Mountains, Nevada). In: Geology and Natural History of the Grand Canyon Region. Four Corners Geological Society, 5th Field Conf., pp. 135-169.

Bissell, H.J. and Childs, O.E., 1958. The Weber Formation of Utah and Colorado. In: Pennsylvanian Rocks of Colorado and Adjacent Areas. Rocky Mount. Assoc. Geol., pp. 27-30.

Blakey, R.C., 1970. Geology of the Paria Northwest quadrangle, Kane County, Utah. Unpubl. M.S. thesis, Univ. of Utah, Salt Lake City, Utah, 171 pp.

Blakey, R.C., 1979. Stratigraphy of the Supai Group (Pennsylvanian-Permian), Mogollon Rim, Arizona. In: Carboniferous Stratigraphy of the Grand Canyon Country, Northern Arizona and Southern Nevada. Field Trip No. 13, Ninth Int. Congress of Carboniferous Stratigraphy and Geology, American Geological Institute, Falls Church, Va., pp. 89-104.

Blakey, R.C., 1980. Pennsylvanian and Early Permian paleogeography, Southern Colorado Plateau and vicinity. In: T.D. Fouch and E.R. Magathan (Editor), Paleozoic Paleogeography of West-Central United States. Rocky Mountain Sect., Soc. Econ. Paleontol. Mineral., pp. 239-257.

Blakey, R.C., 1986. The Coconino Sandstone, does it contain cross-stratified marine deposits? Geol. Soc. Am., Rocky Mountain Sect., Abstr. with Programs, 18: 342.

Blakey, R.C., in press. Triassic and Jurassic geology of southern Colorado Plateau. In: S.J. Reynolds and J.P. Jenney (Editors), Summary of Arizona Geology. Ariz. Geol. Soc.

Blakey, R.C., 1988. Basin tectonics and erg response. In: G. Kocurek (Editor), Late Paleozoic and Mesozoic Eolian 
Deposits of the Western Interior of the United States. Sediment. Geol., 56: 127-151 (this volume).

Blakey, R.C. and Knepp, R., in press. Pennsylvanian and Permian Geology of Arizona. In: S.J. Reynolds and J.P. Jenney (Editors), Summary of Arizona Geology. Ariz. Geol. Soc.

Blakey, R.C. and Middleton, L.T., 1983. Lower Mesozoic stratigraphy and depositional systems, southwest Colorado Plateau. In: K.D. Gurgel (Editor), Geologic Excursions in Stratigraphy and Tectonics-From Southeastern Idaho to the Southern Inyo Mountains, California, via Canyonlands and Arches National Parks, Utah. Utah Geol. Miner. Surv., Spec. Stud., 60: 33-39.

Blakey, R.C., Peterson, F., Caputo, M.V., Geesaman, R.C. and Voorhees, B.J., 1983. Paleogeography of Middle Jurassic continental, shoreline, and shallow marine sedimentation, southern Utah. In: M.W. Reynolds and E.D. Dolly (Editors), Mesozoic Paleogeography of West-Central United States. Rocky Mountain Sect., Soc. Econ. Paleontol. Mineral., pp. 77-100.

Blodgett, R.H., 1984. Nonmarine depositional environments and paleosol development in the Upper Triassic Dolores Formation, southwestern Colorado. In: D.C. Brew (Editor), Field Trip Guidebook. 37th Annual Meeting, Rocky Mountain Sect., Geol. Soc. Am., pp. 46-92.

Bragdon, F.F., 1965. Geologic map and cross sections of Fish Spring Creek and adjacent areas, Sublette and Lincoln Counties, Wyoming. Unpubl. M.S. thesis, Univ. of Wyoming, Laramie, Wyo., 98 pp.

Broomhall, R.W., 1978. Geology of Dry Creek-West Fork area, Central Arizona. Unpubl. M.S. thesis, Northern Arizona Univ., Flagstaff, Ariz., 99 pp.

Bryant, B., 1979. Geology of the Aspen 15-minute quadrangle, Pitkin and Gunnison Counties, Colorado. U.S. Geol. Surv., Prof. Pap., 1073: 146 pp.

Bryant, B., 1985. Structural ancestry of the Uinta Mountains. In: M.D. Picard (Editor), Geology and Energy Resources, Uinta Basin of Utah. Utah Geol. Assoc., pp. 115-120.

Bush, A.L., Bromfield, C.S. and Pierson, C.T., 1959. Areal Geology of the Placerville quadrangle, San Miguel County, Colorado. U.S. Geol. Surv. Bull., 1072-E: 299-384.

Bush, A.L., Marsh, O.T. and Taylor, R.B., 1960. Areal geology of the Little Cone quadrangle, Colorado: U.S. Geol. Surv. Bull., 1082-G: 423-492.

Cadigan, R.A., 1952. The correlation of the Jurassic Bluff and Junction Creek Sandstones in southeastern Utah and southwestern Colorado. Unpubl. M.S. thesis, Pennsylvania State Univ., University Park, Pa., 163 pp.

Campbell, J.A., 1979. Lower Permian depositional system, southern Uncompahgre basin. Permianland, Four Corners Geol. Soc. Guideb., 9th Field Conf., pp. 13-21.

Caputo, M.V., 1980. Depositional history of Middle Jurassic clastic shoreline sequences in southwestern Utah. Unpubl. M.S. thesis, Northern Arizona Univ., Flagstaff, Ariz., 162 pp.

Cater, F.W., 1970. Geology of the Salt Anticline Region in southwestern Colorado. U.S. Geol. Surv., Prof. Pap., 637: $80 \mathrm{pp}$.

Chan, M.A. and Kocurek, G., 1988. Complexities in eolian and marine interactions: Processes and eustatic controls on erg development. In: G. Kocurek (Editor), Late Paleozoic and Mesozoic Eolian Deposits of the Western Interior of the United States. Sediment. Geol., 56: 283-300 (this volume).

Condon, S.M., 1985a. Lithologic descriptions of selected intervals of Jurassic rocks in southeastern Utah, northeastern Arizona and northwest New Mexico. U.S. Geol. Surv., Open-File Rep. OF-85-223, 100 pp.

Condon, S.M., 1985b. Lithologic descriptions of selected Middle-Upper Jurassic rocks from Gallo to Laguna in northwestern New Mexico. U.S. Geol. Surv., Open-File Rep. $\mathrm{OF}-85-126$.

Condon, S.M. and Huffman Jr., A.C., 1984. Stratigraphy and depositional environments of Jurassic rocks, San Juan Basin, New Mexico, with emphasis on the south and west sides. In: D.C. Brew (Editor), Field Trip Guidebook. 37th Annual Meeting, Rocky Mountain Sect., Geol. Soc. Am., pp. 93- 107.

Condon, S.M. and Peterson, F., 1986. Stratigraphy of Middle and Upper Jurassic rocks of the San Juan Basin-historical perspective, current ideas, and remaining problems. In: A Basin Analysis Case Study - The Morrison Formation, Grants Uranium Region, New Mexico. Am. Assoc. Pet. Geol., Stud. Geol., pp. 47-75.

Conner, J.J., 1963. Geology of the Angostura Reservoir quadrangle, Fall River County, South Dakota. U.S. Geol. Surv, Bull., 1063-D: 85-126.

Cloud, R.A., 1983. Geology of the Munds Park-Oak Creek Canyon area, central Arizona. Unpubl. M.S. thesis, Northern Arizona Univ., Flagstaff, Ariz., 159 pp.

Craig, L.C., Holmes, C.N., Freeman, V.L. and Mullens, T.E., 1959. Measured sections of the Morrison and adjacent formations. U.S. Geol. Surv., Open-File Rep. OF-59-485, 700 pp.

Cressman, E.R., 1964. Geology of the Georgetown Canyon-Snowdrift Mountain area, southeastern Idaho. U.S. Geol. Surv. Bull., 1152: 105 pp.

Dane, C.H., 1935. Geology of the Salt Valley anticline and adjacent areas, Grand County, Utah. U.S. Geol. Surv., Prof. Pap., 863: 184 pp.

Darton, N.H., 1906. Mineral resources of the Bighorn Mountain region, Wyoming. U.S. Geol. Surv. Bull., 285-F: $303-310$.

Davidson, E.S., 1967. Geology of the Circle Cliffs area, Garfield and Kane Counties, Utah. U.S. Geol. Surv. Bull., 1229: $140 \mathrm{pp}$.

Dobrovolny, E. and Summerson, C.H., 1946. Geology of northwestern Quay County, New Mexico. U.S. Geol. Surv., Oil and Gas Investigations Preliminary Map OM-62.

Doelger, N.M. and Steidtmann, J.R., 1985. Depositional environments of the Nugget Sandstone, Red Canyon Rim, Fremont County, Wyoming. Wyo. Contrib. Geol., 23 (2): $1-23$. 
Driese, S.G. and Dott Jr., R.H., 1984. Model for sandstone-carbonate "cyclothems" based on upper member of Morgan Formation (Middle Pennsylvanian) of northern Utah and Colorado. Bull. Am. Assoc. Pet. Geol., 68: 574-592.

Eardley, A.J., 1944. Geology of the north-central Wasatch Mountains, Utah. Geol. Soc. Am. Bull., 55: 819-894.

Edwards, D.P., 1985. Depositional controls on the Lower Jurassic Dinosaur Canyon Member of the Moenave Formation, southern Utah and northern Arizona. Unpubl. M.S. thesis, Northern Arizona Univ., Flagstaff, Ariz., 243 pp.

Espach, R.H. Royse Jr., F. 1960. Stratigraphic variations in the eastern Big Hole Mountains, Teton and Bonneville Counties, Idaho. In: D.P. McGookey and D.N. Miller, Jr. (Editors), Overthrust Belt of Southwestern Wyoming and Adjacent Areas. 15th Annual Field Conf. Guidebook, Wyo. Geol. Assoc., pp. 61-71.

Finch, W.I. and Wright, J.C., 1983. Measured stratigraphic sections of Uranium-bearing Upper Triassic rocks of the Dockum Basin, Eastern New Mexico, West Texas and the Oklahoma panhandle with brief discussion of stratigraphic problems. U.S. Geol. Surv., Open-File Rep. OF-83-701, 118 pp.

Finnell, T.L., 1966. Geologic map of the Cibecue Quadrangle, Navajo County, Arizona. U.S. Geol. Surv. Map GQ-545.

Foster, H.L., 1947. Paleozoic and Mesozoic stratigraphy of northern Gros Ventre Mountains and Mount Leidy Highlands, Teton County, Wyoming. Bull. Am. Assoc. Pet. Geol. 31: 1537-1593.

Froidevaux, C.M., 1968. Geology of the Hoback Peak area in the Overthrust Belt, Lincoln and Sublette Counties, Wyoming. Unpubl. M.S. thesis, Univ, of Wyoming, Laramie, Wyo., 126 pp.

Fryberger, S.G., 1984. The Permian upper Minnelusa Formation, Wyoming, ancient example of an offshore-prograding eolian sand sea with geomorphic facies, and systemboundary traps for petroleum. In: J. Goolsby and D. Morton (Editors), 35th Annual Field Conf. Guidebook. Wyo. Geol. Assoc., pp. 241-271.

George, S.E., 1985. Structural geology of the Pavant Mountain front in the Fillmore and Kanosh quadrangles, Millard County, Utah. Brigham Young Univ. Geol. Stud., 32: $39-61$.

Gilluly, J. and Reeside Jr., J.B., 1928. Sedimentary rocks of the San Rafael Swell and some adjacent areas in eastern Utah. U.S. Geol. Surv., Prof. Pap., 150-D: 61-110.

Goldman, M.I. and Spencer, A.C., 1941. Correlation of Cross' La Plata Sandstone, Southwestern Colorado. Bull. Am. Assoc. Pet. Geol. 25: 1745-1767.

Granger, A.E., 1953. Stratigraphy of the Wasatch Range near Salt Lake City, Utah. U.S. Geol. Surv. Circ., 296: 14 pp.

Green, M.W., 1974. The Iyanbito Member (a new stratigraphic unit) of the Jurassic Entrada Sandstone, Gallup-Grants area, New Mexico. U.S. Geol. Surv. Bull., 1395-D: 12 pp.

Gregory, H.E., 1938. The San Juan country, a geographic and geologic reconnaissance of southeastern Utah. U.S. Geol. Surv., Prof. Pap., 188: 123 pp.
Grote, W.F., 1957. Battleship field, Jackson County, Colorado. In: W.C. Finch (Editor), Guidebook to the Geology of North and Middle Park Basins, Colorado. Rocky Mount. Assoc. Geol., pp. 119-121.

Hamilton, W.L., 1978. Geological Map of Zion National Park. Zion Natural History Assoc., Springdale, Utah, 1 sheet.

Hansen, W.R., 1965. Geology of the Flaming Gorge area, Utah-Colorado-Wyoming. U.S. Geol. Surv., Prof. Pap., 490: $196 \mathrm{pp}$.

Hansen, W.R., 1968. Geologic map of the Black Ridge Quadrangle, Delta and Montrose Counties, Colorado. U.S. Geol. Surv. Map GQ-747.

Hansen, W.R., 1971. Geologic map of the Black Canyon of the Gunnison River and vicinity, western Colorado. U.S. Geol. Surv. Map I-584.

Hansen, W.R., 1986. History of faulting in the eastern Uinta Mountains, Colorado and Utah. In: D.S. Stone (Editor), New Interpretations of Northwest Colorado Geology. Rocky Mount. Assoc. Geol., pp. 5-17.

Harshbarger, J.W., Repenning, C.A. and Irwin, J.H., 1957. Stratigraphy of the uppermost Triassic and the Jurassic rocks of the Navajo country. U.S. Geol. Surv., Prof. Pap., 291: 74 pp.

Hawley, C.C., Robeck, R.C. and Dyer, H.B., 1968. Geology, altered rocks, and ore deposits of the San Rafael Swell, Emery County, Utah. U.S. Geol. Surv. Bull., 1239: 115 pp.

Hewett, D.F., 1931. Geology and ore deposits of the Godsprings quadrangle, Nevada. U.S. Geol. Surv., Prof. Pap., 162: $618 \mathrm{pp}$.

Hewett, D.F., 1956. Geology and ore deposits of the Ivanpah quadrangle, Nevada and California. U.S. Geol. Surv., Prof. Pap., 275: 172 pp.

Heylmum, E.B., 1958. Paleozoic stratigraphy and oil possibilities of Kaiparowitz region, Utah. Bull. Am. Assoc. Pet. Geol., 42: 1781-1812.

Hoyt, J.H., 1963. Perm-Pennsylvanian correlations and isopach studies in the northern Denver Basin. In: P.J. Katich and D.W. Bolyard (Editors), Geology of the Northern Denver Basin and Adjacent Areas. Rocky Mount. Assoc. Geol., 14th Field Conf. Guide., pp. 68-83.

Huff, L.C. and Lesure, F.G., 1965. Geology and uranium deposits of Montezuma Canyon area, San Juan County, Utah. U.S. Geol. Surv. Bull., 1190: 102 pp.

Hunt, C.B., Averitt, P. and Miller, R.L., 1953. Geology and geography of the Henry Mountains region. U.S. Geol. Surv., Prof. Pap., 228: 234 pp.

Imlay, R.W., 1980. Jurassic paleobiogeography of the conterminous United States and its continental setting. U.S. Geol. Surv., Prof. Pap., 1062: 134 pp.

Irwin, C.D., 1976. Pefmian and Lower Triassic reservoir rocks of central Utah. In: J.G. Hill (Editor), Symposium on Geology of the Cordilleran Hingeline. Rocky Mount. Assoc. Geol., pp. 193-202.

Irwin, D., 1977. Subsurface cross sections of Colorado. Rocky Mount. Assoc. Geol., Spec. Publ., 2.

Irwin, J.H., Stevens, P.R. and Cooley, M.E., 1971. Geology of the Paleozoic rocks, Navajo and Hopi Indian Reservations, 
Arizona, New Mexico, and Utah. U.S. Geol. Surv., Prof. Pap., 521-C: 32 pp.

Johansen, S.J., 1981. Depositional environments of the Queantoweap Sandstone on northwestern Arizona and southern Nevada. Unpubl. M.S. thesis, Univ. of Arizona, Tucson, Ariz., 213 pp.

Johansen, S.J., 1988. Origins of Upper Paleozoic quartzose sandstones, American southwest. In: G. Kocurek (Editor), Late Paleozoic and Mesozoic Eolian Deposits of the Western Interior of the United States. Sediment. Geol., 56: 153-166 (this volume).

Johnston, I., 1975. A detailed stratigraphic and environmental analysis of the San Rafael Group (Jurassic). Unpubl. Ph.D. diss., Univ. of Arizona, Tucson, Ariz., $510 \mathrm{pp}$.

Kamola, D.L. and Chan, M.A., 1988. Coastal dune facies, Permian Cutler Formation (White Rim Sandstone), Capitol Reef National park area, southern Utah. In: G. Kocurek (Editor), Late Paleozoic and Mesozoic Eolian Deposits of the Western Interior of the United States. Sediment. Geol., 56: $341-356$ (this volume).

Keefer, W.B., 1957. Geology of the Du Noir area, Fremont County, Wyoming. U.S. Geol. Surv., Prof. Pap., 294-E: 155-221.

Keefer, W.R. and Troyer, M.L., 1964. Geology of the Shotgun Butte area, Fremont County, Wyoming. U.S. Geol. Surv. Bull., 1157: 123 pp.

Kelley, V.C., 1955. Regional tectonics of the Colorado Plateau and relationships to the origin and distribution of Uranium. Univ. of New Mexico Publ. in Geology, 5: 120 pp.

Kerr, D.R. and Dott Jr., R.H., 1988. Eolian dune types preserved in the Tensleep Sandstone (Pennsylvanian-Permian), north-central Wyoming. In: G. Kocurek (Editor), Late Paleozoic and Mesozoic Eolian Deposits of the Western Interior of the United States. Sediment. Geol., 56: 383-402 (this volume).

Knapp, R.R., 1976. Depositional environments and diagenesis of the Nugget Sandstone, south-central Wyoming, northeast Utah, and northwest Colorado. Unpubl. M.S. thesis, Univ. of Wyoming, Laramie, Wyo., 67 pp.

Knight, J.B., 1986. Eolian bedform reconstruction-a case study from the Page Sandstone (Jurassic), northern Arizona. Unpubl. M.S. thesis, Univ. of Texas, Austin, Tex., 180 pp.

Knowles, T., Nordstrom, P. and Klemt, W.B., 1982. Evaluating the ground-water resources of the High Plains of Texas, final report. Texas Dep. of Water Resources, LP 173, v. 1.

Kocurek, G., 1980. Significance of bounding surfaces, interdune deposits, and dune stratification types in ancient erg reconstruction. Unpubl. Ph.D. Diss., Univ. of Wisconsin, Madison, Wisc., 369 pp.

Kocurek, G., 1981. Erg reconstruction: Entrada Sandstone (Jurassic) of northern Utah and Colorado. Palaeogeogr., Palaeoclimatol., Palaeoecol., 36: 125-153.

Kocurek, G. and Dott Jr., R.H., 1983. Jurassic paleogeography and paleoclimate of the central and southern Rocky Mountains region. In: M.W. Reynolds and E.D. Dolly (Editors), Mesozoic Paleogeography of West-Central United States.
Rocky Mountain Sect., Soc. Econ. Paleontol. Mineral., pp. 101-116.

Kocurek, G. and Hunter, R.E., 1986. Origin of polynomial fractures in sand, uppermost Navajo and Page Sandstones, Page Arizona. J. Sediment. Petrol., 56: 895-904.

Langenheim Jr., R.L., 1957. Jurassic stratigraphy in Elk Mountains, west-central Colorado. Bull. Am. Assoc. Pet. Geol., 41: 2576-2583.

Lessentine, R.H., 1969. Kaiparowits and Black Mesa Basins: stratigraphic synthesis. In: Geology and Natural History of the Grand Canyon Region. Four Corners Geological Society, 5th Field Conf., pp. 91-113.

Lewis, R.Q. and Campbell, R.H., 1965. Geology and uranium deposits of Elk Ridge and vicinity, San Juan County, Utah. U.S. Geol. Surv., Prof. Pap., 474-B: 69 pp.

Lohman, S.W., 1981. The geologic story of Colorado National Monument. U.S. Geol. Surv. Bull., 1508: 142 pp.

Longwell, C.R., 1928. Geology of the Muddy Mountains, Nevada, with a section through the Virgin Range to the Grand Wash Cliffs, Arizona. U.S. Geol. Surv. Bull., 798: $152 \mathrm{pp}$.

Loope, D.B., 1984, Eolian origin of upper Paleozoic Sandstones, southeastern Utah. J. Sediment. Petrol., 54: 563-580.

Love, J.D., 1957. Stratigraphy and correlations of Triassic rocks in central Wyoming. Wyoming Geological Assoc. Guidebook, 12th Annual Field Conf., Southwest Wind River Basin, pp. 39-46.

Love, J.D., Thompson, R.M., Johnson, C.O., Sharkey, H.H.R., Tourtelot, H.A. and Zapp, A.D., 1945a. Stratigraphic Sections and Thickness Maps of Lower Cretaceous and Nonmarine Jurassic Rocks of Central Wyoming. U.S. Geol. Surv. Oil and Gas Investigations, Preliminary Chart 13.

Love, J.D., Thompson, R.M., Johnson, C.O., Sharkey, H.H.R., Tourtelot, H.A. and Zapp, A.D., 1945b. Stratigraphic Sections and Thickness Maps of Jurassic Rocks in Central Wyoming. U.S. Geol. Surv. Oil and Gas Investigations, Preliminary Chart 14.

Love, J.D., Tourtelot, H.A., Johnson, C.O., Thompson, R.M., Sharkey, H.H.R. and Zapp, A.D., 1947. Stratigraphic sections of Mesozoic rocks in central Wyoming. Wyo. Geol. Surv. Bull., 38: 59 pp.

Lucas, S.G., Kietzke, K.K. and Hunt, A.P., 1985. The Jurassic System in east-central New Mexico. New Mexico Geological Society Guidebook, 36th Field Conf., Santa Rosa, pp. 213-242.

Lupe, R., 1983. Stratigraphic sections of subsurface Jurassic rocks in the San Juan Basin, New Mexico, Colorado, Utah, and Arizona. U.S. Geol. Surv. Oil and Gas Chart OC-118.

Mack, G.H., 1979. Littoral marine depositional model for the Cedar Mesa Sandstone (Permian), Canyonlands National Park, Utah. Permianland, Four Corners Geol. Soc. Guidebook, 9th Field Conf., pp. 33-37.

Mallory, W.M., 1967. Pennsylvanian and associated rocks of Wyoming. U.S. Geol. Surv., Prof. Pap., 554-G: 31 pp.

Mankin, C.J., 1958. Stratigraphy and sedimentary petrology of Jurassic and Pre-Graneros Cretaceous rocks, northeastern 
New Mexico. Unpubl. Ph.D. diss., Univ. of Texas, Austin, Tex., $231 \mathrm{pp}$.

Mankiewicz, D. and Steidtmann, J.R., 1979. Depositional environments and diagenesis of the Tensleep Sandstone, eastern Big Horn Basin, Wyoming. In: P.A. Scholle and P.R. Schluger (Editors), Aspects of Diagenesis. Soc. Econ. Paleontol. Mineral., Spec. Publ., 26: 319-336.

Mansfield, G.R., 1927. Geography, geology, and mineral resources of part of southeastern Idaho. U.S. Geol. Surv., Prof. Pap., 152: 453 pp.

Marzolf, J.E., 1983a. Early Mesozoic eolian transition from cratonal margin to orogenic-volcanic arc. In: K.D. Gurgel (Editor), Geological Excursions in Stratigraphy and Tectonics-From Southeastern Idaho to the Southern Inyo Mountains, California, via Canyonlands and Arches National Parks, Utah. Utah Geol. Miner. Surv., Spec. Stud., 60: 39-46.

Marzolf, J.E., 1983b. Changing wind and hydrologic regimes during deposition of the Navajo and Aztec Sandstones, Jurassic(?), southwestern U.S. In: M.E. Brookfield and T.S. Ahlbrandt (Editors), Eolian Sediments and Processes. (Developments in Sedimentology, 38) Elsevier, Amsterdam, pp. 635-660.

Maughan, E.K. and Wilson, R.F., 1960. Pennsylvanian and Permian strata in southern Wyoming and northern Colorado. In: Rocky Mountain Association of Geologists, Guide to the Geology of Colorado, pp. 34-42.

Maxwell, C.H., 1976. Stratigraphy and structure of the Acoma region, New Mexico. In: L.A. Woodward and S.A. Northrop (Editors), Tectonics and Mineral Resources of Southwestern North America. N.M. Geol. Soc., Spec. Publ., 6: 95-101.

Maxwell, C.H., 1982. Mesozoic stratigraphy of the Laguna-Grants region. In: J.A. Grambling and S.G. Wells (Editors), Albuquerque Country II, 33rd Field Conference. N.M. Geol. Soc., pp. 261-266.

McAllen, W.R., 1984. Petrology and diagenesis of the Esplanade Sandstone, central Arizona. Unpubl. M.S. thesis, Northern Arizona Univ., Flagstaff, Ariz., 90 pp.

McFall, C.C., 1955. Geology of the Escalante-Boulder area, Garfield County, Utah. Unpubl. Ph.D. diss., Yale Univ., 180 pp.

McKay, E.J., 1972. Geologic Map of the Show Low Quadrangle, Navajo County, Arizona. U.S. Geol. Surv. Map GQ-973.

McKee, E.D., 1933. The Coconino Sandstone-its history and origin. Carnegie Institute Washington Publ. 440: 77-115.

McKee, E.D., 1982. The Supai Group of Grand Canyon. U.S. Geol. Surv., Prof. Pap., 1173: 504 pp.

McKee, E.D., Oriel, S.S., Swanson, V.E., MacLachlan, M.E., MacLachlan, J.C., Ketner, K.B., Goldsmith, J.W., Bell, R.Y. and Jameson, D.J., 1956. Paleotectonic maps of the Jurassic System. U.S. Geol. Surv., Misc. Geol. Invest. Map I-175, 6 pp.

McKnight, E.T., 1940. Geology of area between Green and Colorado Rivers, Grand and San Juan Counties, Utah. U.S. Geol. Surv. Bull., 908: 147 pp.
McNair, A.H., 1951. Paleozoic stratigraphy of part of northwestern Arizona. Bull. Am. Assoc. Pet. Geol., 35: 503-541.

Middleton, L.T. and Blakey, R.C., 1983. Sedimentologic processes and controls on the intertonguing of the fluvial Kayenta and eolian Navajo Sandstone, northern Arizona and southern Utah. In: M.E. Brookfield and T.S. Ahlbrandt (Editors), Eolian Sediments and Processes. (Developments in Sedimentology, 38) Elsevier, Amsterdam, pp. 613-634.

Miller, E.L. and Carr, M.D., 1978. Recognition of possible Aztec-equivalent sandstones and associated Mesozoic metasedimentary deposits within the Mojave magmatic arc in the southwestern Mojave Desert, California. In: D.G. Howell and K.A. McDougall (Editors), Mesozoic Paleogeography of the Western United States. Pacific Coast Sect., Soc. Econ. Paleontol. Mineral., pp. 283-289.

Morris, E.C., 1953. Geology of the Big Piney area, Summit County, Utah. Unpubl. M.S. thesis, Univ. of Utah, Salt Lake City, Utah, 66 pp.

Muehlberger, W.R., 1967. Geology of Chama Quadrangle, New Mexico. New Mexico State Bureau of Mines and Mineral Resources, New Mexico Institute of Mining and Technology Bull., 89: 114 pp.

Mullens, T.E., 1960. Geology of the Clay Hills area, San Juan County, Utah. U.S. Geol. Surv. Bull., 1087-H: 259-336.

Nance, H.S., 1988. Interfingering of evaporites and red beds: An example from the Queen/Grayburg formation, Texas. In: G. Kocurek (Editor), Late Paleozoic and Mesozoic Eolian Deposits of the Western Interior of the United States. Sediment. Gol., 56: 357-381 (this volume).

Noble, L.F., 1922. A section of Paleozoic formations of the Grand Canyon at Bass Trail. U.S. Geol. Surv., Prof. Pap., 131: 23-73.

Nomenclature Committee, 1956. Wyoming stratigraphy part 1: Subsurface stratigraphy of the pre-Niobrara Formations in Wyoming. Wyom. Geol. Assoc., 97 pp.

O'Sullivan, R.B., 1965. Geology of the Cedar Mesa-Boundary Butte area, San Juan County, Utah. U.S. Geol. Surv. Bull., 1186: $128 \mathrm{pp}$.

O'Sullivan, R.B., 1978. Stratigraphic sections of Middle Jurassic San Rafael Group from Lohali Point, Arizona to Bluff, Utah. U.S. Geol. Surv,, Oil and Gas Invest. Chart OC-77.

O'Sullivan, R.B., 1980a. Stratigraphic sections of Middle Jurassic San Rafael Group from Wilson Arch to Bluff in southeastern Utah. U.S. Geol. Surv. Oil and Gas Invest. Chart OC-102.

O'Sullivan, R.B., 1980b. Stratigraphic sections of the Middle Jurassic San Rafael Group and related rocks from the Green River to the Moab area in east-central Utah. U.S. Geol. Surv., Misc. Field Stud., M.F.-1247.

O'Sullivan, R.B., 1981a. Stratigraphic sections of some Jurassic rocks from near Moab, Utah to Slick Rock, Colorado. U.S. Geol. Surv. Oil and Gas Invest. Chart OC-107.

O'Sullivan, R.B., 1981b. Stratigraphic sections of Middle Jurassic Entrada Sandstone and related rocks from Salt Valley to Dewey Bridge in east-central Utah. U.S. Geol. Surv. Oil and Gas Invest. Chart OC-113. 
O'Sullivan, R.B., 1984. Stratigraphic sections of Middle Jurassic San Rafael Group and related rocks from Dewey Bridge, Utah to Uravan, Colorado. U.S. Geol. Surv. Oil and Gas Invest. Chart OC-124.

O'Sullivan, R.B. and Pierce, F.W., 1983. Stratigraphic diagram of Middle Jurassic San Rafael Group and associated formations from the San Rafael Swell to Bluff in southeastern Utah. U.S. Geol. Surv. Oil and Gas Invest. Chart OC-119.

O'Sullivan, R.B. and Pipiringos, G.N., 1983. Stratigraphic sections of Middle Jurassic Entrada Sandstone and related rocks from Dewey Bridge, Utah to Bridgeport, Colorado. U.S. Geol. Surv. Oil and Gas Invest. Chart OC-122.

Otto, E.P. and Picard, M.D., 1975. Stratigraphy and oil and gas potential of Entrada Sandstone (Jurassic), northeastern Utah. In: D.W. Bolyard (Editor), Deep Drilling Frontiers of the Central Rocky Mountains. Rocky Mount. Assoc. Geol., pp. 129-139.

Pacht, J.A., 1976. Depositional environments and diagenesis of the Nugget Sandstone, western Wyoming and north-central Utah. Unpubl. M.S. thesis, Univ. of Wyoming, Laramie, Wyo., 99 pp.

Peirce, H.W., 1964. Internal correlation of the Permian DeChelly Sandstone, Defiance Plateau, Arizona. Contrib. Geol. North. Ariz. Mus. North. Ariz. Bull., 40: 15-31.

Peirce, H.W., 1966. Permian stratigraphy of the Defiance Plateau, Arizona. 18th Field Conf. Guideb., N.M. Geol. Soc., pp. 57-62.

Peirce, H.W., Keith, S.B. and Wilt, J.C. 1970. Coal, oil, natural gas, helium, and uranium in Arizona. Ariz. Bur. Mines Bull., 182: 289 pp.

Peterson, F., 1980. Sedimentology as a strategy for uranium exploration-concepts gained from analysis of a uraniumbearing depositional sequence in the Morrison Formation of south-central Utah. In: C.E. Turner-Peterson (Editor), Uranium in Sedimentary Rocks-Application of the Facies Concept to Exploration. Rocky Mountain Sect., Soc. Econ. Paleontol. Mineral., Short Course Notes, pp. 65-126.

Peterson, F., 1984. Fluvial sedimentation on a quivering craton -influence of slight crustal movements on fluvial processes, Upper Jurassic Morrison Formation, western Colorado Plateau. Sediment. Geol., 38: 21-49.

Peterson, F., 1986. Jurassic paleotectonics in the west-central part of the Colorado Plateau, Utah and Arizona. In: J.A. Peterson (Editor), Paleotectonics and Sedimentation in the Rocky Mountain Region, United States. Mem. Am. Assoc. Pet. Geol., 41: 563-596.

Peterson, F., 1988. Pennsylvanian to Jurassic eolian transportation systems in the western United States. In: G. Kocurek (Editor), Late Paleozoic and Mesozoic Eolian Deposits of the Western Interior of the United States. Sediment. Geol., 56: 207-260 (this volume).

Peterson, F., in press. Stratigraphy and nomenclature of Middle and Upper Jurassic rocks, Utah and Arizona. U.S. Geol. Surv. Bull., 1633-B.

Peterson, F., and Pipiringos, G.N., 1979. Stratigraphic relations of the Navajo Sandstone to Middle Jurassic forma- tions, southern Utah and northern Arizona. U.S. Geol. Surv., Prof. Pap., 1035-B: 43 pp.

Peterson, F. and Tyler, N., 1985. Field guide to the upper Salt Wash alluvial complex. In: R.M. Flores and M.D. Harvey (Editors), Field Guidebook to Modern and Ancient Fluvial Systems in the United States. Proc. Third Int. Fluvial Sedimentology Conf., Colorado State Univ., Boulder, Colo., pp. $45-64$.

Phoenix, D.A., 1963. Geology of the Lees Ferry area, Coconino County, Arizona. U.S. Geol. Surv. Bull., 1137: 86 pp.,

Pipiringos, G.N., 1968. Correlation and nomenclature of some Triassic and Jurassic rocks in south-central Wyoming. U.S. Geol. Surv., Prof. Pap., 594-D: D1-D26.

Pipiringos, G.N., 1972. Upper Triassic and pre-Morrison Jurassic rocks. In: K. Segerstrom and E.J. Young (Editors), General Geology of the Hahns Peak and Farwell Mountain Quadrangles, Routt County, Colorado. U.S. Geol. Surv. Bull., 1349: 18-29.

Pipiringos, G.N., Hail Jr., W.J. and Izett, G.A., 1969. The Chinle (Upper Triassic) and Sundance (Upper Jurassic) formations in north-central Colorado. U.S. Geol. Surv. Bull., 1274-N: 35 pp.

Pipiringos, G.N. and O'Sullivan, R.B., 1976. Stratigraphic sections of some Triassic and Jurassic rocks from Douglas, Wyoming to Boulder, Colorado. U.S. Geol. Surv. Oil and Gas Invest. Chart OC-69.

Pipiringos, G.N. and O'Sullivan, R.B., 1978. Principal unconformities in Triassic and Jurassic rocks, Western Interior United States-a preliminary survey. U.S. Geol. Surv., Prof. Pap., 1035-A: 29 pp.

Poole, F.G. and Stewart, J.H., 1964. Chinle Formation and Glen Canyon Sandstone in northeastern Utah and northwestern Colorado. U.S. Geol. Surv., Prof. Pap., 501-D: D30-D39.

Porter, M.L., 1985. Sedimentology and petrology of an Early Jurassic erg margin-Aztec Sandstone, southern Nevada and southern California. Unpubl. Ph.D. diss., Univ. of Wisconsin, Madison, Wisc., $217 \mathrm{pp}$.

Post, E.V., 1967. Geology of the Cascade Springs quadrangle, Fall River County, South Dakota. U.S. Geol. Surv. Bull., 1063-L: 443-504.

Proffett Jr., J.M. and Dilles, J.H., 1984. Geologic Map of the Yerington District, Nevada. Nevada Bureau of Mines and Geology Map 77.

Rapaport, I., Hadfield, J.P. and Olsen, R.H., 1952. Jurassic Rocks of the Zuni Uplift, New Mexico. U.S. Atomic Energy Commission, RMO-642, 49 pp.

Rascoe, B. and Baars, D.L., 1972. Permian System. Geologic Atlas of the Rocky Mountain Region, Rocky Mount. Assoc. Geol., pp. 143-165.

Rautman, C.A., 1975. Sedimentology of the Lower Sundance Formation (Upper Jurassic), Wyoming Region. Wyo. Geol. Assoc., Earth Sci. Bull.. 8: 1-16.

Rawson, R.R. and Turner-Peterson, C.E., 1980, Paleogeography of northern Arizona during the deposition of the Permian Toroweap Formation. In: Paleozoic Paleogeogra- 
phy of the West-Central United States. Rocky Mountain Sect., Soc. Econ. Paleontol. Mineral., pp. 341-352.

Read, C.B. and Wanek, A.A., 1961. Stratigraphy of outcropping Permian rocks in parts of northeastern Arizona and adjacent areas. U.S. Geol. Surv., Prof. Pap., 374-H: H1-H10.

Read, C.B., Wood, G.H., Wanek, A.A. and McKee, P.V., 1949. Stratigraphy and geologic structure in the Piedro River Canyon, Archuleto County, Colorado. U.S. Geol. Surv. Oil and Gas Invest., Preliminary Map 96.

Richardson, G.B., 1941. Geology and mineral resources of the Randolph quadrangle, Utah-Wyoming. U.S. Geol. Surv. Bull., 923: 54 pp.

Richmond, G.M., 1945. Geology and oil possibilities at the northwest end of the Wind River Mountains, Sublette County, Wyoming. U.S. Geol. Surv. Oil and Gas Invest., Preliminary Map OM-31.

Robinson, C.S., Mapel, W.J. and Bergendahl, M.H., 1964. Stratigraphy and structure of the northern and western flanks of the Black Hills uplift, Wyoming, Montana, and South Dakota. U.S. Geol. Surv., Prof. Pap., 404: 134 pp.

Rubin, D.M. and Hunter, R.E., 1983. Reconstructing bedform assemblages from compound crossbedding. In: M.E. Brookfield and T.S. Ahlbrandt (Editors), Eolian Sediments and Processes. (Developments in Sedimentology, 38) Elsevier, Amsterdam, pp. 407-427.

Ruede, G.M., 1951. A mapping and field study of the Unkpapa Sandstone in the Black Hills, South Dakota. M.S. thesis, Univ. of Nebraska, Lincoln, Nebr., 91 pp.

Sacrison, W.R., 1958. A study of the Jurassic Unkpapa Sandstone of the Black Hills region, western South Dakota. unpubl. M.S. thesis, Univ. of Wyoming, Laramie, Wyo., 78 pp.

Santos, E.S., 1975. Lithology and uranium potential of Jurassic formations in the San Ysidro-Cuba and Majors Ranch areas, northwestern New Mexico. U.S. Geol. Surv. Bull., 1329: 22 pp.

Santos, E.S. and Moench, R.H., 1971. Measured sections of the Morrison Formation and related rocks in northwestern New Mexico. U.S. Geol. Surv., Open-File Rep. OF-71-245, $61 \mathrm{pp}$.

Santos, E.S. and Turner-Peterson, C.E., 1986. Tectonic setting of the San Juan basin in the Jurassic. In: C.E. TurnerPeterson, E.S. Santos and N.S. Fishman (Editors), A Basin Analysis Case Study-the Morrison Formation, Grants uranium region, New Mexico. Am. Assoc. Pet. Geol., Stud. Geol., 22: 27-33.

Saperstone, H.I. and Ethridge, F.G., 1984. Origin and paleotectonic setting of the Pennsylvanian Quadrant Sandstone, Southwestern Montana. In: J. Goolsby and D. Morton (Editors), Wyoming Geological Association 35th Annual Field Conf. Guideb., pp. 309-331.

Saucier, A.E., 1967a. The Morrison Formation in the Gallup region. In: Guidebook of Defiance-Zuni-Mt. Taylor Region, Arizona and New Mexico. New Mexico Geological Society, 18th Field Conf. 1967, Socorro, New Mexico, New
Mexico Bureau of Mines and Mineral Resources, pp. 138-144.

Saucier, A.E., 1967b. The Morrison and related formations in the Gallup regional Unpubl. M.S. thesis, Univ. of New Mexico, Albuquerque, N.M., 106 pp.

Savela, C.E., 1977. Textural analysis of the Exeter Sandstone, northeastern New Mexico. Compass, 54: 29-35.

Scott, G.L., 1960. Permian sedimentary framework of the Four Corners region. Unpubl. M.S. thesis, Univ. of Wisconsin, Madison, Wisc., 127 pp.

Sears, J.D., 1956. Geology of Comb Ridge and vicinity north of the San Juan River, San Juan County, Utah. U.S. Geol. Surv. Bull., 1021-E: 167-207.

Shawe, D.R., Simmons, G.C. and Archbold, N.L., 1968. Stratigraphy of the Slick Rock district and vicinity, San Miguel and Dolores Counties, Colorado. U.S. Geol. Surv., Prof. Pap., 576-A: A1-A108.

Smith, C.T., Budding, A.J. and Pitrat, C.W., 1961. Geology of the southeastern part of the Chama Basin. N.M. State Bur. Mines Miner. Resour. Bull., 75: 57 pp.

Smith, J.F., Huff, L.C., Hinrichs, E.N. and Luedke, R.G., 1963. Geology of the Capitol Reef area, Wayne and Garfield Counties, Utah. U.S. Geol. Surv., Prof. Pap., 363: 102 pp.

Smith, S.W., 1951. Sedimentary study of the Jurassic of Quay County, New Mexico. Unpubl. M.S. thesis, Texas Technological College, $61 \mathrm{pp}$.

Steidtmann, J.R., 1974. Evidence for eolian origin of cross-stratification in sandstone of the Casper Formation, southernmost Laramie Basin, Wyoming. Geol. Soc. Am. Bull., 85: 1835-1842.

Steed, D.A., 1980. Geology of the Virgin River Gorge, northwest Arizona. Brigham Young Univ. Geol. Stud., 27: 96-114.

Stewart, J.H., Poole, F.G. and Wilson, R.F., 1972. Stratigraphy and origin of the Chinle Formation and related Upper Triassic strata in the Colorado Plateau region. U.S. Geol. Surv., Prof. Pap., 690: 336 pp.

Stewart, W.D. and Walker, R.G., 1980. Eolian coastal dune deposits and surrounding marine sandstones, Rocky Mountain Supergroup (Lower Pennsylvanian), southeastern British Columbia. Can. J. Earth Sci., 17: 1125-1140.

Stokes, W.L., 1959. Jurassic rocks of the Wasatch Range and vicinity. In: N.C. Williams (Editor), Guidebook to the Geology of the Wasatch and Uinta Mountains Transition Area. Intermountain Association of Petroleum Geologists, 10th Annual Field Conf., pp. 109-114.

Strobell, Jr., J.D., 1956. Geology of the Carrizo Mountains area in northeastern Arizona and northwestern New Mexico. U.S. Geol. Surv. Oil and Gas Invest. Map OM-160.

Szigeti, G.J. and Fox, J.E., 1981. Unkpapa Sandstone (Jurassic), Black Hills, South Dakota-an eolian facies of the Morrison Formation. In: F.G. Ethridge and R.M. Flores (Editors), Recent and Ancient Nonmarine Depositional Environments-Models for Exploration. Soc. Econ. Paleontol. Mineral., Spec. Publ., 31: 331-349. 
Thaden, R.E., Thrites, A.F. and Finnell, T.L., 1964. Geology and ore deposits of the White Canyon area, San Juan and Garfield Counties, Utah. U.S. Geol. Surv. Bull., 1125: 166 pp.

Thomas, C.R., McCann, F.T. and Raman, N.D., 1945. Mesozoic and Paleozoic stratigraphy in northwestern Colorado and northeastern Utah. U.S. Geol. Surv. Oil and Gas Invest. Preliminary Chart 16.

Thomas, H.D., and Krueger, M.L., 1946. Late Paleozoic and Early Mesozoic stratigraphy of Uinta Mountains, Utah. Bull. Am. Assoc. Pet. Geol., 30: 1255-1293.

Thompson, W.O., 1949. Lyon Sandstone of Colorado Front Range. Bull. Am. Assoc. Pet. Geol., 33: 52-72.

Trauger, F.D. and Bushman, F.X., 1964. Geology and ground water in the vicinity of Tucumcari, Quay County, New Mexico. New Mexico State Engineer, Santa Fe, N.M., Tech. Rep., 9: 177 pp.

Trimble, L.M. and Doelling, H.H., 1978. Geology and uranium-vanadium deposits of the San Rafael River mining area, Emery County, Utah. Utah Geol. Miner. Surv. Bull., 113: 122 pp.

Uyger, K., 1980. Hydraulic and petrographic characteristics of the Navajo Sandstone in southern Utah. Unpubl. M.S. thesis, Univ, of Utah, Salt Lake City, Utah, 134 pp.

Vanderwilt, J.W., 1937. Geology and mineral deposits of the Snowmass Mountain area, Gunnison County, Colorado. U.S. Geol. Surv. Bull., 884: 184 pp.

Ver Hoeve, M.W., 1982. The petrology and reservoir character of the Entrada Sandstone (Jurassic) Durango, Colorado. Unpubl. M.S. thesis, Univ. of Texas, Austin, Tex., 240 pp.

Vonderharr, J., 1986. Microstratigraphy of the eolian White House Member of the De Chelly Sandstone of northeastern Arizona. Unpubl. M.S. thesis, Northern Arizona Univ., Flastaff, Ariz.. $137 \mathrm{pp}$.

Vincelette, R.R. and Chittum, W.E., 1981. Exploration for oil accumulations in Entrada Sandstone, San Juan Basin, new Mexico. Bull. Am. Assoc. Pet. Geol., 65: 2546-2570.

Walker, T.R. and Harms, J.C., 1972. Eolian origin of Flagstone beds, Lyons Sandstone (Permian), Type area, Boulder County, Colorado. Mount. Geol., 9: 279-288.

Wanek, A.A., 1962. Reconnaissance geologic map of parts of Harding, San Miguel and Mora Counties, New Mexico. U.S. Geol. Surv. Oil and Gas Invest. Map OM-208.

Wanek, A.A. and Stevens, J.G., 1953. Reconnaissance geologic map of the Kaibito and Moenkopi Plateaus and parts of the Painted Desert, Coconino County, Arizona. U.S. Geol. Surv. Oil and Gas Invest. Map OM-145.

Wanless, H.R., Belknap, R.L. and Foster, H., 1955. Paleozoic and Mesozoic rocks of Gros Ventre, Teton, Hoback and Snake River Ranges, Wyoming. Geol. Soc. Am. Mem., 63: $90 \mathrm{pp}$.

Ward, D.W., 1957. Geology of the Middle Fork of the Michigan River, Jackson County, Colorado. In: W.C. Finch (Editor), Guide to the Geology of North and Middle Park Basins, Colorado. Rocky Mount. Assoc. Geol. Guideb., pp. $70-73$.
Weaver, C.L., 1980. Geology of the Blue Mountain quadrangle - Beaver and Iron Counties, Utah. Brigham Young Univ. Geol. Stud., 27: 116 132 .

Weimer, P., 1981, Bedrock geology of the Ridgeway area, northwestern Flank, San Juan Mountains, CO. In: R.C. Epis and J.F. Callonder (Editors), Western Slope Co. N.M. Geol. Soc. Guideb., 32nd Annual Field Conf., pp. 97-104.

Welsh, J.E., 1976. Relations of Pennsylvanian-Permian stratigraphy to the late Mesozoic thrust belt in the eastern Great Basin, Utah and Nevada. In: J.G. Hill (Editor), Symposium on the Geology of the Cordilleran Hingeline. Rocky Mount Assoc. Geol., pp. 153-160.

Wengerd, S.A., 1962. Regional structural-stratigraphic cross section, east-central Arizona to west-central New Mexico. In: Mogollon Rim Region, East-Central Arizona. N.M. Geol., Soc., 13th Field Conf., 58 pp.

Wilson, R.F., 1965. Triassic and Jurassic strata of southwestern Utah. In: H.D. Goode and R.A. Robison (Editors), Resources for Power-Geology and Resources of SouthCentral Utah. Utah Geol. Soc. Intermountain Assoc. of Pet. Geol., Guideb. to the Geology of Utah, pp. 31-46.

Witkind, I.J. and Thaden, R.E., 1963. Geology and uranium-vanadium deposits of the Monument Valley area, Apache and Navajo Counties, Arizona. U.S. Geol. Surv. Bull., 1103: $171 \mathrm{pp}$.

Wood, G.H., Kelley, V.C. and MacAlpin, A.J., 1948. Geology of the southern part of Archuleta County, Colorado. U.S. Geol. Surv. Oil and Gas Invest., Preliminary Map 81.

Wood Jr., G.H., Northrop, S.A. and Griggs, R.L., 1953. Geology and stratigraphy of Koehler and Mount Laughlion Quadrangles and parts of Abbott and Springer Quadrangles, eastern Colfax County, New Mexico. U.S. Geol. Surv. Oil and Gas Invest. Map OM-141.

Wright, R.P., 1973. Marine Jurassic of Wyoming and South Dakota-its paleoenvironments and paleobiogeography. Univ. Michigan, Mus. Paleontol., Pap. Paleontol., 2: 49 pp.

Wright, J.C. and Dickey, D.D., 1963. Relations of the Navajo and Carmel Formations in southwest Utah and adjoining Arizona. U.S. Geol. Surv., Prof. Pap., 450-E: E63-E67.

Wright, J.C. and Dickey, D.D., 1978. East-west cross-sections of the Jurassic Age San Rafael Group rocks from western Colorado to central and western Utah. U.S. Geol. Surv., Open-File Rep., OF-78-784.

Wright, J.C. and Dickey, D.D., 1979. Stratigraphic sections of Jurassic San Rafael Group and adjacent rocks in Rio Arriba and Santa Fe Counties, New Mexico. U.S. Geol. Surv., Open-File Rep. OF-79-247.

Wright, J.C. and Dickey, D.D., 1979. Stratigraphic sections of Jurassic San Rafael Group and adjacent rocks in Routt, Park, Pitkin, and Gunnison Counties, Colorado. U.S. Geol. Surv., Open-File Rep. OF-79-249.

Wright, J.C. and Dickey, D.D., 1979. Stratigraphic sections of Jurassic San Rafael Group and adjacent rocks in San Juan and McKinley Counties, New Mexico. U.S. Geol. Surv., Open-File Rep. OF-79-715.

Wright, J.C. and Dickey, D.D., 1978. North-south cross sec- 
tions of the Jurassic San Rafael Group in Utah and western Colorado. U.S. Geol. Surv., Open-File Rep. OF-78-965.

Wright, J.C. and Dickey, D.D., 1978. Miscellaneous cross sections of the Jurassic San Rafael group in southern Utah. U.S. Geol. Surv., Open-File Rep. OF-78-966.

Wright, J.C. and Dickey, D.D., 1979. Stratigraphic sections of the Jurassic San Rafael Group and adjacent rocks in Rio Blanco and Garfield Counties, Colorado. U.S. Geol. Surv., Open-File Rep. OF-79-245.

Wright, J.C. and Dickey, D.D., 1979. Stratigraphic sections of Jurassic San Rafael Group and adjacent rocks in Apache County, Arizona. U.S. Geol. Surv., Open-File Rep. OF-79246.

Wright, J.C., Dickey, D.D. and Freeman, V.L., 1979. Stratigraphic sections of Jurassic San Rafael Group and adjacent rocks in Valencia and Sandoval Counties, New Mexico. U.S. Geol. Surv., Open-File Rep. OF-79-836.

Wright, J.C., Dickey, D.D. and Snyder, R.P., 1980. Measured stratigraphic sections of Jurassic San Rafael Group and adjacent rocks in Garfield County, Utah. U.S. Geol. Surv., Open-File Rep. OF-80-308, 83 pp.

Wright, J.C., Shawe, D.R. and Lohman, S.W., 1962. Definitions of members of Jurassic Entrada Sandstone in east central Utah and west central Colorado. Bull. Am. Assoc. Pet. Geol., 46: 2057-2070.

York, H.F., 1957. Geology of the Elk Mountain anticline, North Park, Colorado. In: W.C. Finch (Editor), Guide to the Geology of North and Middle Park Basins, Colorado. Rocky Mount. Assoc. Geol. Guideb., pp. 74-81. 